\title{
Natural Gas Productive Capacity for the Lower 48 States 1985 Through 1997
}

\section{December 1996}

\section{Energy Information Administration}

Office of Oil and Gas

U.S. Department of Energy

Washington, DC 20585 


\section{Preface}

The Natural Gas Productive Capacity for the Lower 48 States 1985 Through 1997 is the fifth in this series of reports prepared by the Energy Information Administration (EIA). The four previous reports were published in 1991, 1993,1994, and 1996. $\{1,2,3,4\}$ The EIA Dallas Field Office has prepared five earlier reports regarding natural gas productive capacity. These reports, Gas Deliverability and Flow Capacity of Surveillance Fields, reported deliverability and capacity data for selected gas fields in major gas-producing areas. $\{5,6,7,8,9\}$ The data in the reports were based on gas-well back-pressure tests and estimates of gas-in-place for each field or reservoir. These reports use proven well testing theory, most of which has been employed by industry since 1936, when the Bureau of Mines first published Monograph 7.\{10\}

This publication is used by the Congress, Federal and State agencies, industry, and other interested parties to obtain accurate data of the lower 48 States' natural gas production history and wellhead productive capacity. Capacity projections from this report are used in EIA's Short-Term Energy Outlook Quarterly Projections. The report also contains a projection of lower 48 States' gas production requirements and wellhead productive capacity. These data are essential for the evaluation of the adequacy of future gas supplies, especially in periods of peak heating or cooling demand.

Total demand for natural gas in the United States is met by a combination of natural gas production, underground gas storage, imported gas, and supplemental gaseous fuels. This report examines the natural gas production element of the total gas demand. Domestic natural gas production supplies the majority of the natural gas demand requirements for the lower 48 States. The production requirement continues to increase while drilling has remained at low levels, a fact that this has raised some concern about the adequacy of future gas supplies, and gas producers' ability to meet periods of peak heating or cooling demand.

A history of natural gas production and natural gas productive capacity at the wellhead, along with a projection of the same, is shown hown in tables and figures. Data are compiled and presented for the lower 48 States, Texas, Louisiana, California, Kansas, New Mexico, Oklahoma, Gulf of Mexico Outer Continental
Shelf (OCS), Southeast area, Rocky Mountain area, and an eighteen State area that includes the remaining gas producing States. The EIA generates projections based on historical gas-well drilling and production data from State, Federal, and private sources. In addition to conventional gas-well gas, coalbed gas and oil-well gas are also included. Also presented for each category are charts showing the number of gas-well completions by year and the percent of total wellhead productive capacity by age. Alaska is excluded from this report because Alaskan gas does not enter the lower 48 States pipeline system.

Appendix A contains the methodology used for the report. Appendix B contains the model abstract. Appendix $C$ compares the results of previous productive capacity reports. Appendix $D$ contains the calculations and a table of productive capacity per new gas-well completion. A glossary of terms used in this report is provided to assist readers in more fully understanding the data.

This annual gas capacity report was prepared by the Dallas Field Office staff of the Reserves and Production Branch, Reserves and Natural Gas Division, Office of Oil and Gas, Energy Information Administration. General information regarding preparation of the report may be obtained from Kenneth A. Vagts, Director of the Office of Oil and Gas (202/586-6401) or John $\mathrm{H}$. Wood, Director of the Dallas Field Office (214/767-2200).

Questions may be directed to:

- James N. Hicks Phone 214/767-2908, FAX 214/767-2204

E-mail: jhicks@eia.doe.gov

- Hafeez Rahman Phone 214/767-0880, FAX 214/767-2204

E-mail: hrahman@eia.doe.gov

- Velton T. Funk Phone 214/767-0884, FAX 214/767-2204

E-mail: vfunk@eia.doe.gov

Significant contributions were made by Gary Long (rig model). A. H. Payne, Rhonda S. Green, Ralph Russell and LaTonya Thomas also contributed to this publication. 


\section{DISCLAMMER}

Portions of this document may be illegible in electronic image products. Images are produced from the best available original document. 


\section{DISCLAIMER}

This report was prepared as an account of work sponsored by an agency of the United States Government. Neither the United States Government nor any agency thereof, nor any of their employees, make any warranty, express or implied, or assumes any legal liability or responsibility for the accuracy, completeness, or usefulness of any information, apparatus, product, or process disclosed, or represents that its use would not infringe privately owned rights. Reference herein to any specific commercial product, process, or service by trade name, trademark, manufacturer, or otherwise does not necessarily constitute or imply its endorsement, recommendation, or favoring by the United States Government or any agency thereof. The views and opinions of authors expressed herein do not necessarily state or reflect those of the United States Government or any agency thereof. 


\section{Contents}

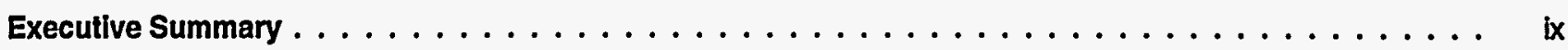

1. Introduction $\ldots \ldots \ldots \ldots \ldots \ldots \ldots \ldots \ldots \ldots \ldots \ldots \ldots \ldots \ldots \ldots \ldots \ldots \ldots \ldots$

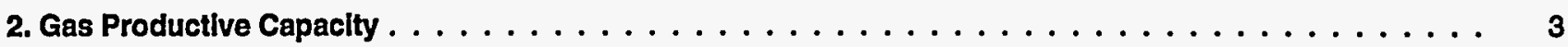

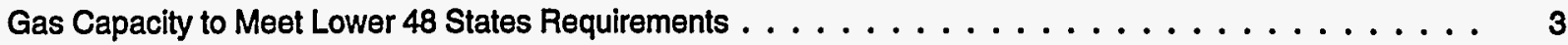

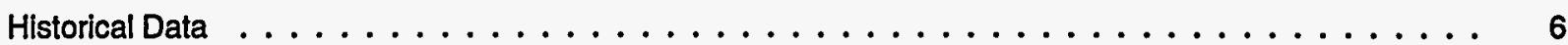

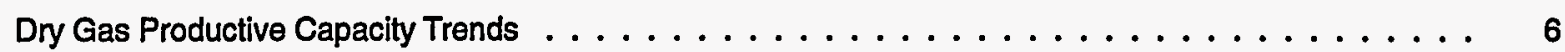

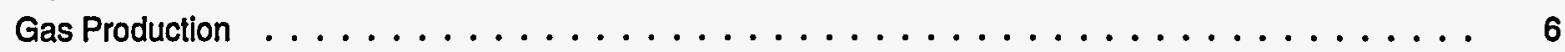

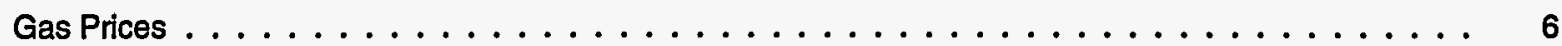

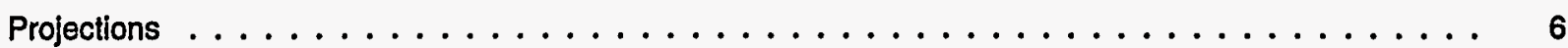

Dry Gas Productive Capacity and Production . . . . . . . . . . . . . . . . 6

New Well Completions . . . . . . . . . . . . . . . . . . . . . . . 10

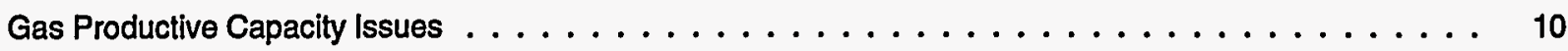

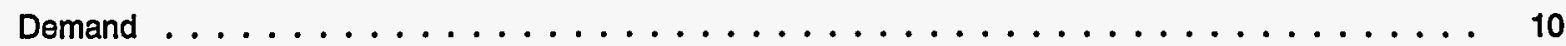

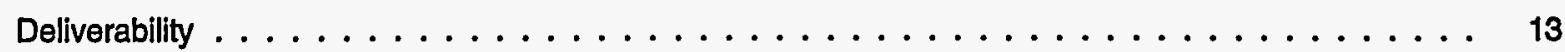

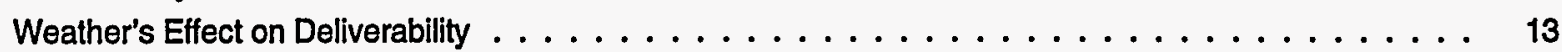

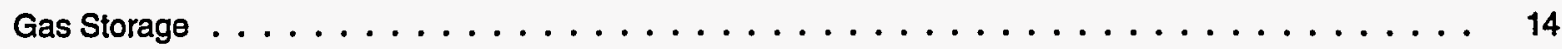

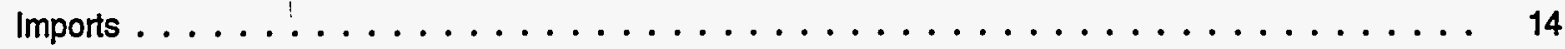

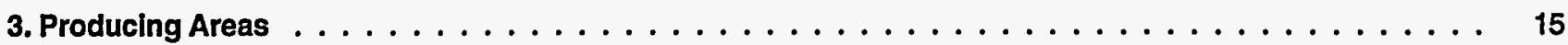

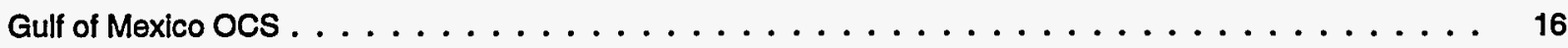

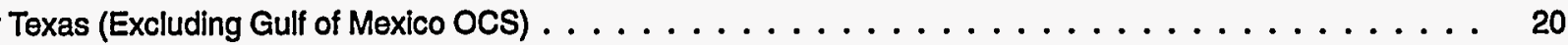

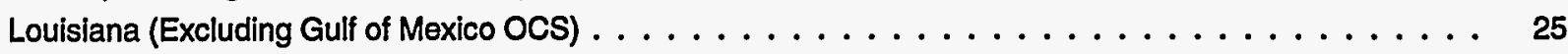

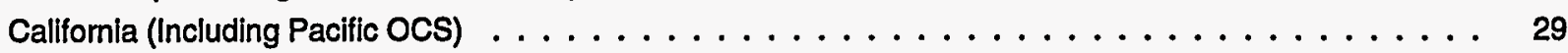

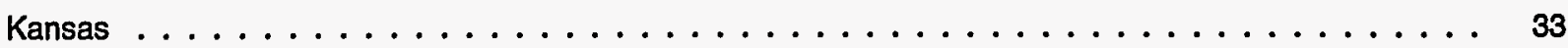

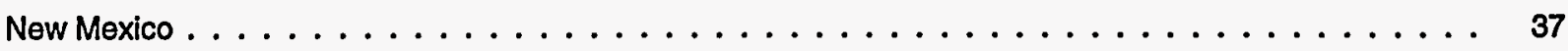

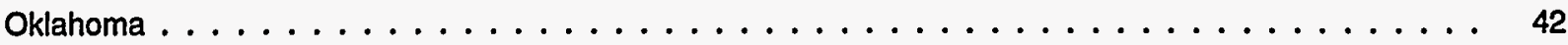

Southeast (Excluding Gulff of Mexico) $\ldots \ldots \ldots \ldots \ldots \ldots \ldots \ldots \ldots \ldots$

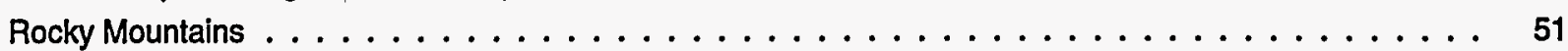

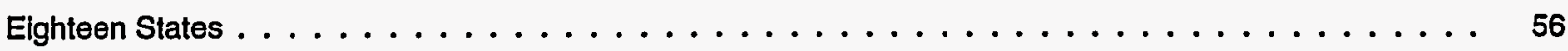

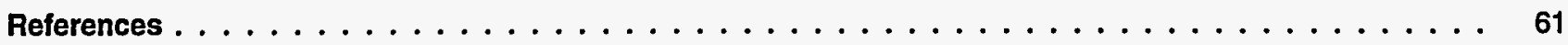

Appendices

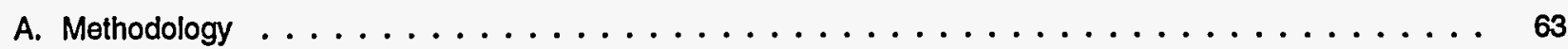

Gas-Well Gas Productive Capacity . . . . . . . . . . . . . . . . . 65

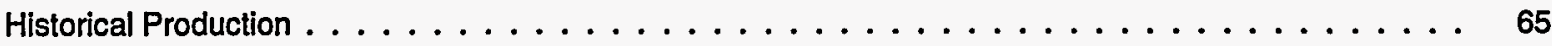

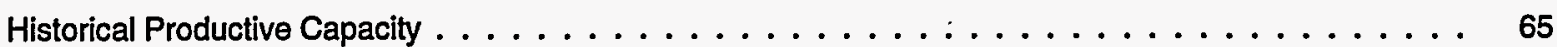

Projections of Productive Capacity $\ldots \ldots \ldots \ldots \ldots \ldots \ldots \ldots \ldots \ldots \ldots \ldots$

Projected Productive Capacity of Old Vintage Wells $\ldots \ldots \ldots \ldots \ldots \ldots$

Projected Productive Capacity of New Vintage Wells . . . . . . . . . . . . . . . . 70

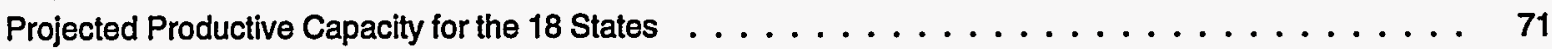

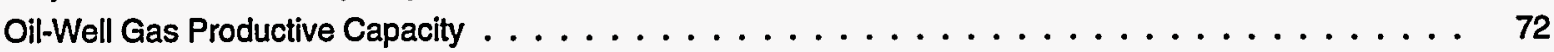

Coalbed Gas Productive Capacity . . . . . . . . . . . . . . . . . . . . . 72

Gas Demand . . . . . . . . . . . . . . . . . . . . . . . 74

Drilling and Gas-Well Completions $\ldots \ldots \ldots \ldots \ldots \ldots \ldots \ldots \ldots \ldots \ldots$

Gas Rig Model $\ldots \ldots \ldots \ldots \ldots \ldots \ldots \ldots \ldots \ldots \ldots \ldots \ldots \ldots$

Percentage Gas Rigs Model . . . . . . . . . . . . . . . . . . . . . 79 
Rig Efficiency Model $\ldots \ldots \ldots \ldots \ldots \ldots \ldots \ldots \ldots \ldots \ldots \ldots$

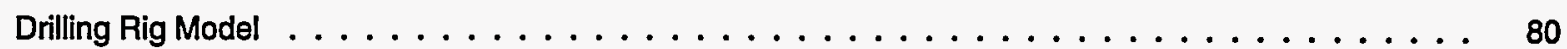

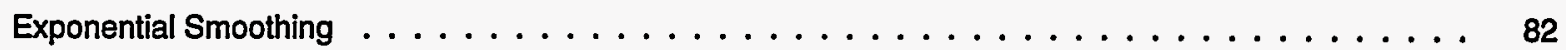

B. Model Abstract $\ldots \ldots \ldots \ldots \ldots \ldots \ldots \ldots \ldots \ldots \ldots \ldots \ldots \ldots \ldots \ldots$

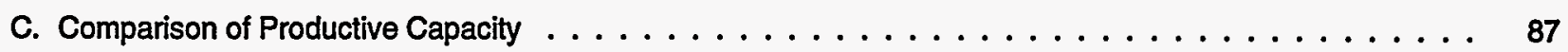

D. Dry Gas-Well Capacity per New Gas-Well Completion Added . . . . . . . . . . . . . . . . . . . . 91

Glossary . . . . . . . . . . . . . . . . . . . . . . . . . . . . . . 95

\section{Tables}

1. Lower 48 States Dry Gas Production and Wellhead Productive Capacity, 1985-1995 . . . . . . . . . . 7

2. Lower 48 States Dry Gas Production and Wellhead Productive Capacity Projections, 1996-1997 . . . . . . 11

3. Gulf of Mexico OCS Dry Gas Production and Wellhead Productive Capacity, 1985-1995 . . . . . . . . . 17

4. Gulf of Mexico OCS Dry Gas Production and Wellhead Productive Capacity Projections, 1996-1997 _ . . . 18

5. Texas (Excluding Gulf of Mexico OCS) Dry Gas Production and Wellhead Productive Capacity,

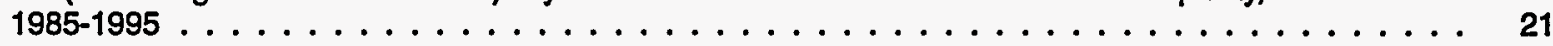

6. Texas (Excluding Gulf of Mexico OCS) Dry Gas Production and Wellhead Productive Capacity

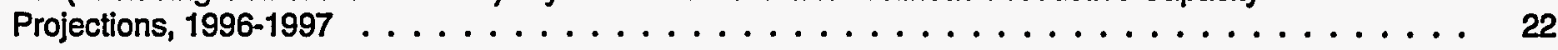

7. Louisiana (Excluding Gulf of Mexico OCS) Dry Gas Production and Wellhead Productive Capacity,

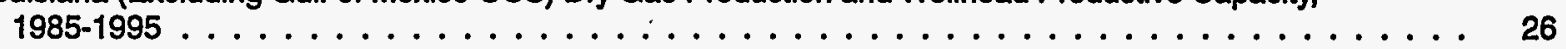

8. Louisiana (Excluding Gulf of Mexico OCS) Dry Gas Production and Wellhead Productive Capacity

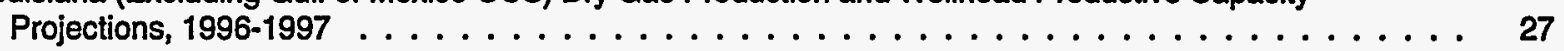

9. Califomia (Including Pacific OCS) Dry Gas Production and Wellhead Productive Capacity, 1985-1995 . . . 30

10. California (Including Pacific OCS) Dry Gas Production and Wellhead Productive Capacity Projections,

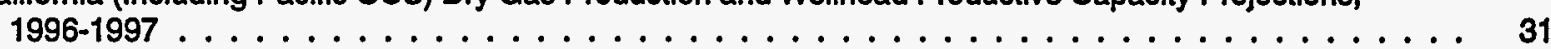

11. Kansas Dry Gas Production and Wellhead Productive Capacity, 1985-1995 . . . . . . . . . . . . . . 34

12. Kansas Dry Gas Production and Wellhead Productive Capacity Projections, 1996-1997 . . . . . . . . . 35

13. New Mexico Dry Gas Production and Wellhead Productive Capacity, 1985-1995 . . . . . . . . . . . 38

14. New Mexico Dry Gas Production and Wellhead Productive Capacity Projections, 1996-1997 _ . . . . . . . 39

15. Oklahoma Dry Gas Production and Wellhead Productive Capacity, 1985-1995 . . . . . . . . . . . . 43

16. Oklahoma Dry Gas Production and Wellhead Productive Capacity Projections, 1996-1997 . . . . . . . . 44

17. Southeast (Excluding Gulf of Mexico OCS) Dry Gas Production and Wellhead Productive Capacity,

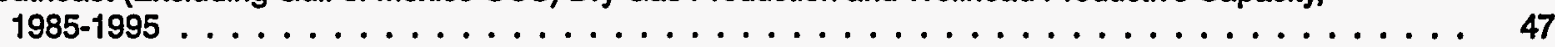

18. Southeast (Excluding Gulf of Mexico OCS) Dry Gas Production and Wellhead Productive Capacity Projections, $1996-1997 \ldots \ldots \ldots \ldots \ldots \ldots \ldots \ldots \ldots \ldots$

19. Rocky Mountains Dry Gas Production and Wellhead Productive Capacity, 1985-1995 . . . . . . . . . 52

20. Rocky Mountains Dry Gas Production and Wellhead Productive Capacity Projections, 1996-1997 . . . . . 53

21. Eighteen States Dry Gas Production and Wellhead Productive Capacity, 1985-1995 . . . . . . . . . . . 57

22. Eighteen States Dry Gas Production and Wellhead Productive Capacity Projections, 1996-1997 _ . . . . 58

A1. Coalbed Gas Cumulative Production and Number of Completions by Area for Vintage Years,

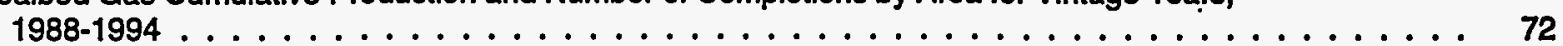

A2. Quarterly Dry Gas Production Forecast, and 1996 and $1997 \ldots \ldots \ldots \ldots \ldots \ldots \ldots \ldots$

A3. Marketed, Dry, and Gross Gas Production for $1994 \ldots \ldots \ldots \ldots$. . . . . . . . . . . . . 75 
A4. Quarterly Dry Gas Production by State and Area for 1994 . . . . . . . . . . . . . . . . . . . . 76

A5. Quarterly Dry Gas Fraction by State and Area for 1994 . . . . . . . . . . . . . . . . . . . 76

A6. Quarterly Gross Gas Demand by State and Area for 1995, 1996, and 1997 . . . . . . . . . . . . . 77

D1. Average Initial Flow Rates, Ultimate Recovery, and Decline Exponent on a Conventional Gas-Well

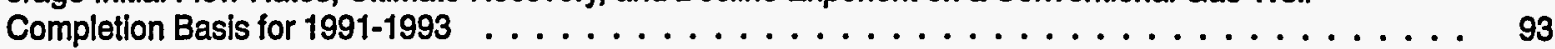

\section{Figures}

1. Lower 48 States Dry Gas Monthly Production Rate and Wellhead Productive Capacity, 1985-1997 . . . . . 3

2. Lower 48 States Natural Gas Production, 1985-1994 . . . . . . . . . . . . . . . . . . . . . . . . . 4

3. Lower 48 States - Producing States and Areas . . . . . . . . . . . . . . . . . . . . . 4

4. Lower 48 States Productive Capacity and Supply Schematic . . . . . . . . . . . . . . . . . . . 5

5. Natural Gas Price by Category, 1985-1994 . . . . . . . . . . . . . . . . . . . . . . . 8

6. Lower 48 States Gross Natural Gas Production by Type, 1985-1994 . . . . . . . . . . . . . . . . . . 8

7. Dry Natural Gas Production from Lower 48 Producing States, 1985-1994 . . . . . . . . . . . . . . . 9

8. Lower 48 States Dry Coalbed Gas Monthly Rate and Wellhead Productive Capacity, 1985-1997 . . . . . 9

9. Lower 48 States Gas-Well Completions Added During Year, 1985-1997 . . . . . . . . . . . . . . . . . . 12

10. Percent of Total Wellhead Productive Capacity of Lower 48 States Gas Wells (Minus the 18 States Group) by Well Age, 1985-1997 (Base Case) . . . . . . . . . . . . . . . . . . . . . . . . . 12

11. Gulf of Mexico OCS Dry Gas Monthly Production Rate and Wellhead Productive Capacity, 1985-1997 . . . 16

12. Gulf of Mexico OCS Gas-Well Completions Added During Year, 1985-1997 . . . . . . . . . . . . . . . 19

13. Percent of Total Wellhead Productive Capacity of Gulf of Mexico OCS Gas Wells, by Age, 1985-1997 (Base Case) . . . . . . . . . . . . . . . . . . . . . . . . 19

14. Texas (Excluding Gulf of Mexico OCS) Dry Gas Monthly Production Rate and Wellhead Productive

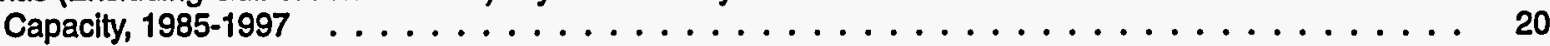

15. Texas (Excluding Gulf of Mexico OCS) Gas-Well Completions Added During Year, 1985-1997 . . . . . . . 23

16. Percent of Total Wellhead Productive Capacity of Texas (Excluding Gulf of Mexico OCS) Gas Wells, by Age, 1985-1997 (Base Case) . . . . . . . . . . . . . . . . . . . . . . . . . 23

17. Texas (Excluding Gulf of Mexico OCS) Monthly Gross Gas-Well Gas Productive Capacity and G-10 Rate,

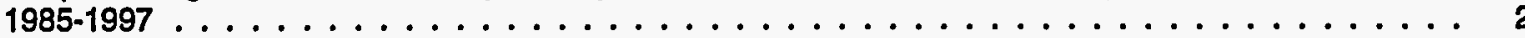

18. Loulsiana (Excluding Gulf of Mexico OCS) Dry Gas Monthly Production Rate and Wellhead Productive

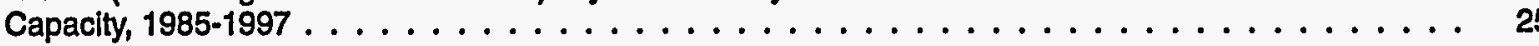

19. Louisiana (Excluding Gulf of Mexico OCS) Gas-Well Completions Added During Year, 1985-1997 . . . . . . 28

20. Percent of Total Wellhead Productive Capacity of Louisiana (Excluding Gulf of Mexico OCS) Gas Wells, by Age, 1985-1997 (Base Case) . . . . . . . . . . . . . . . . . . . . . . . . . . 28

21. Califomia (Including Pacific OCS) Dry Gas Monthly Production Rate and Wellhead Productive Capacity,

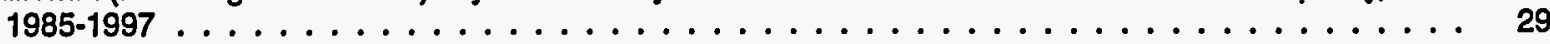

22. California (Including Pacific OCS) Gas-Well Completions Added During Year, 1985-1997 . . . . . . . . . 32

23. Percent of Total Wellhead Productive Capacity of Califomia (Including Pacific OCS) Gas Wells, by Age,

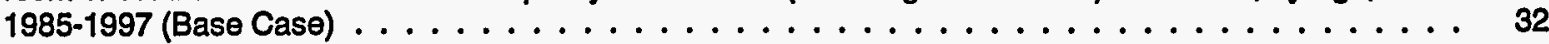

24. Kansas Dry Gas Monthly Production Rate and Wellhead Productive Capacity, 1985-1997 . . . . . . . . . 33

25. Kansas Gas-Well Completions Added During Year, 1985-1997 . . . . . . . . . . . . . . . . . . . . 36

26. Percent of Total Wellhead Productive Capacity of Kansas Gas Wells, by Age, 1985-1997 (Base Case) . . . . 36

27. New Mexico Dry Gas Monthly Production Rate and Wellhead Productive Capacity, 1985-1997 . . . . . . 37 
28. New Mexico Dry Coalbed Gas Monthly Production Rate and Wellhead Productive Capacity, 1985-1997 . . 40

29. New Mexico Gas-Well Completions Added During Year, 1985-1997 . . . . . . . . . . . . . . . . . . . 40

30. Percent of Total Wellhead Productive Capacity of New Mexico Gas Wells, by Age, 1985-1997 (Base Case) . . . . . . . . . . . . . . . . . . . . . . . . . . 41

31. Oklahoma Dry Gas Monthly Production Rate and Wellhead Productive Capacity, 1985-1997 . . . . . . . 42

32. Oklahoma Gas-Well Completions Added During Year, 1985-1997 . . . . . . . . . . . . . . . . . . . 45

33. Percent of Total Wellhead Productive Capacity of Oklahoma Gas Wells, by Age 1985-1997 (Base Case) . . 45

34. Southeast (Excluding Gulf of Mexico OCS) Dry Gas Monthly Production Rate and Wellhead Productive Capacity, 1985-1997 . . . . . . . . . . . . . . . . . . . . . 46

35. Southeast (Excluding Gulf of Mexico OCS) Dry Coalbed Gas Monthly Production Rate and Wellhead Productive Capacity, 1985-1997 . . . . . . . . . . . . . . . . . . . . . . . . 49

36. Southeast (Excluding Gulf of Mexico OCS) Gas-Well Completions Added During Year, 1985-1997 . . . . . 49

37. Percent of Total Wellhead Productive Capacity of Southeast (Excluding Gulf of Mexico OCS) Gas Wells,

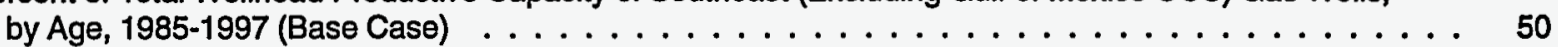

38. Rocky Mountains Dry Gas Monthly Production Rate and Wellhead Productive Capacity, 1985-1997 . . . . 51

39. Rocky Mountains Dry Coalbed Gas Monthly Production Rate and Wellhead Productive Capacity,

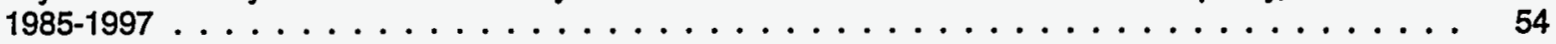

40. Rocky Mountains Gas-Well Completions Added During Year, 1985-1997 . . . . . . . . . . . . . . . . 54

41. Percent of Total Wellhead Productive Capacity of Rocky Mountains Gas Wells, by Age, 1985-1997 (Base Case) . . . . . . . . . . . . . . . . . . . . . . . . . 55

42. Eighteen States Dry Gas Monthly Production Rate and Wellhead Productive Capacity, 1985-1997 . . . . . 56

43. Eighteen States Gas-Well Completions Added During Year, 1985-1997 . . . . . . . . . . . . . . . . . 59

A1. Screening Process ... . . . . . . . . . . . . . . . . . . . . . . . . . . . .

A2. Gross Gas-Well Gas Productive Capacity for the Gulf of Mexico OCS 1982 Vintage Year . . . . . . . . . 67

A3. Capacity and Production Rates for the Gulf of Mexico OCs for 1982 Vintage Year . . . . . . . . . . 69

A4. Theoretical Hyperbolic Type Curve for Production and Capacity . . . . . . . . . . . . . . 70

A5. New Mexico Coalbed Gas-Well Completion Production and Peak Production Rate . . . . . . . . . . 73

C1. Comparisons of Dry Gas Productive Capacity for the 1991,1993, 1994, 1995, and 1996 Studies . . . . . 87 


\section{Executive Summary}

Natural gas productive capacity in the lower 48 States is expected to be adequate to meet monthly production requirements under normal weather conditions through 1997 for three drilling cases (Figure ES1). Capacity projections are shown for low, base, and high drilling cases associated with low, base, and high price scenarios from the Energy Information Administration Short-Term Integrated Forecasting System, Fourth Quarter 1996 (Table ES1). Exceptionally high peak-day or peak-week heating or cooling demand may exceed projected productive capacity, or production may be limited by other factors, such as pipeline availability. Wellhead productive capacity sets the upper limit on natural gas production. Nonetheless, the natural gas industry has developed methods to meet peak demand, such as deliveries from storage and peak-day shaving. These developments have been greatly promoted at the Federal level by the movements to lessen regulation by the Federal Energy Regulatory Commission. Increased reliance on market forces also encourages industry efficiency, as customers with fuel-switching capability consume other fuels in response to higher gas prices. Lastly, effective demand might be lowered by reducing service to customers that have interruptible contracts.

This is the fifth in the series of EIA reports on natural gas wellhead productive capacity in the lower 48 States. The series document a decline in gas productive capacity beginning in 1986 that was clearly reversed in 1996. Natural gas productive capacity is projected to increase in 199.6 for the low, base, and high drilling cases and in 1997 for the base and high cases (Figure ES1). This gradual increase in surplus capacity reflects mainly new discoveries in the Gulf of Mexico Outer Continental Shelf.

The major conclusions of this study are:

- Monthly wellhead productive capacity of dry gas will be adequate to meet production requirements in the low, base, and high cases through 1997.

Figure ES1. Lower 48 States Dry Gas Monthly Production Rate and Wellhead Productive Capacity, 1985-1997

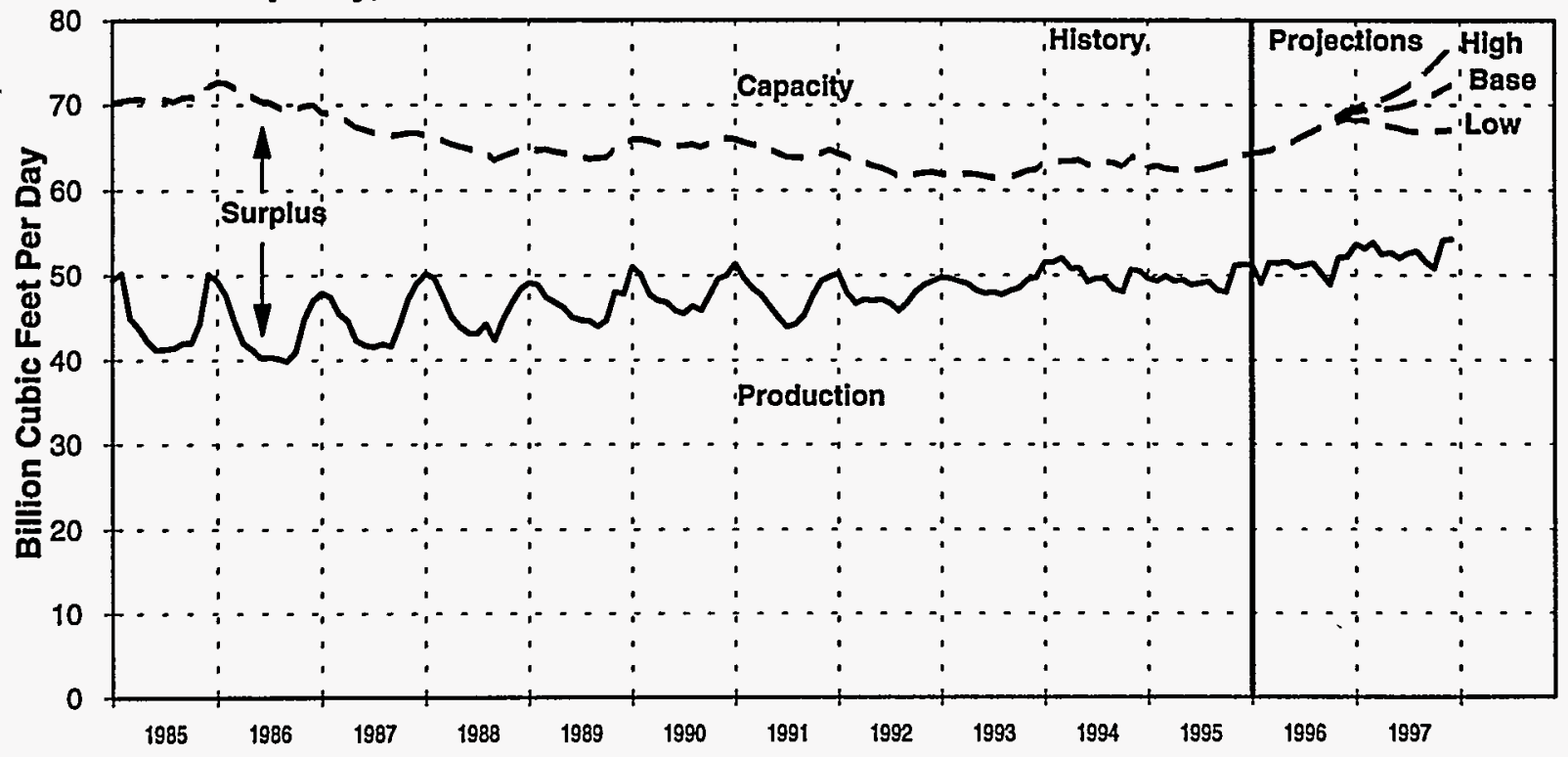

Note: Production projection plotted for base case only. The 1995 estimated history is based on Model GASCAP94 C110196 projections.

Sources: Production History: Energy Information Administration, Office of Oil and Gas; Dwight's Energydata, Inc.; and Model GASCAP94 C110196. Productive Capacity: Model GASCAP94 C110196. Production Projections: Energy Information Administration, Short-Term Integrated Forecasting System, Fourth Quarter 1996, and Model GASCAP94 C110196. 
- In fact, the surplus monthly productive capacity will be higher in December 1997 than in December 1995 for the base and high cases.

- In particular, the largest gas producing area, the Gulf of Mexico Federal Offshore, is expected to meet its historical market share of U.S. production and maintain a substantial surplus productive capacity.

- Beyond 1997, a sufficient number of new wells and/or imports must be added each year in order to ensure an adequate gas capacity and supply.

For decades the lower 48 States natural gas productive capacity has been adequate to meet production requirements. In the 1970 's, the capacity surplus was small because of market structure (split between interstate and intrastate), increasing production requirements, and insufficient drilling. In the early 1980's lower production requirements, together with increased drilling and tight gas price incentives, led to a large surplus capacity. After 1986, this large surplus began to decline as requirements for gas increased, gas prices fell along with oil prices, and gas-well completions dropped sharply. In late December 1989, the decline in this surplus, accompanied by exceptionally high requirements and temporary weather-related production losses, led to concerns about the adequacy of productive capacity for natural gas. These concerns were moderated by the gas system's performance during the unusually severe winter weather in March 1993 and January 1994.

Monthly natural gas wellhead productive capacity estimates are for conventional and coalbed gas-well completions and oil-well completions in the lower 48 States. The different drilling levels assumed in three cases are functions of oil and gas prices and gas production requirements (Table ESI).

Beginning in 1987, coalbed gas production and capacity began a rapid increase. By the end of 1995, the coalbed gas capacity was 5 percent of the total gas-well gas capacity. After 1993, the coalbed production and capacity increased at a lower rate. Coalbed gas capacity is still projected to be 5 percent of the total at the end of 1997 in spite of a decline of coalbed gas capacity in the Southeast for 1996 and 1997.

The existence of a surplus wellhead productive capacity does not signify that the entire gas capacity could be produced and delivered. The ability of a well to deliver gas into a pipeline system (deliverability) is always equal to or less than wellhead productive capacity. Deliverability is that volume of gas that can be produced from a well, reservoir, or field during a given

Table ES1. Annual Wellhead Price, December Production, and December Productive Capacity of Gas, 1985, 1994, 1995, 1996, and 1997

\begin{tabular}{|c|c|c|c|c|c|}
\hline Year/Case & $\begin{array}{c}\text { Price } \\
\text { (nominal } \\
\text { dollars) }\end{array}$ & $\begin{array}{c}\text { Production } \\
\text { (billion cubic } \\
\text { feet per day) }\end{array}$ & $\begin{array}{c}\text { Productive } \\
\text { Capacity } \\
\text { (billion cubic } \\
\text { feet per day) }\end{array}$ & $\begin{array}{c}\text { Productive } \\
\text { Capacity Surplus } \\
\text { (billion cubic } \\
\text { feet per day) }\end{array}$ & $\begin{array}{c}\text { Productive } \\
\text { Capacity } \\
\text { Utilization } \\
\text { (percent) }\end{array}$ \\
\hline \multicolumn{6}{|l|}{ History } \\
\hline 1985 & 2.51 & 50.1 & 72.1 & 22.1 & 69.4 \\
\hline 1994 & 1.88 & 50.5 & 64.0 & 13.5 & 78.9 \\
\hline 1995 & - 1.59 & 51.2 & 64.1 & 12.9 & 79.9 \\
\hline \multicolumn{6}{|l|}{ Projections } \\
\hline 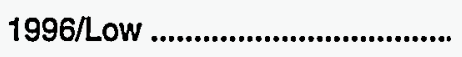 & 1.99 & 52.2 & 68.4 & 16.2 & 76.3 \\
\hline 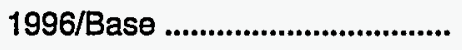 & 2.07 & 52.2 & 69.0 & 16.8 & 75.6 \\
\hline 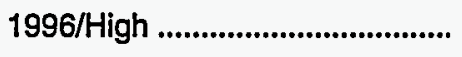 & 2.11 & 52.2 & 69.3 & 17.2 & 75.3 \\
\hline 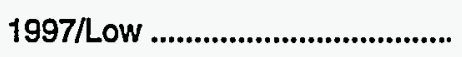 & 1.72 & 54.2 & 67.0 & 12.7 & 81.0 \\
\hline 1997/Base & . 1.85 & 54.2 & 72.3 & 18.1 & 75.0 \\
\hline 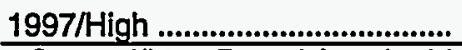 & 2.15 & 54.2 & 77.0 & 22.7 & 70.5 \\
\hline
\end{tabular}


period of time against a certain wellhead back-pressure under actual reservoir conditions, taking into account restrictions imposed by pipeline capacity, gas plant capacity, contracts, or regulatory bodies.

At the end of 1994, deliverability into the lower-48 pipeline system was estimated to be 55 billion cubic feet per day of dry gas, only 87 percent of the dry gas productive capacity at the wellhead. However, there is substantial uncertainty in this deliverability estimate. Should the surplus in wellhead productive capacity decline, more reliance would be placed on gas withdrawals from storage to meet peak heating and cooling demand. Gas storage requirements can be met by maintaining gas production that is closer to gas productive capacity throughout the year. This would lead to smaller seasonal variations in gas production. 


\section{Introduction}

Natural gas demand in the lower 48 States has been increasing during the last few years. Natural gas-well drilling has remained at low levels during these same years. This has raised concern about the adequacy of future gas supplies, especially in periods of peak heating or cooling demand.

Total demand for natural gas in the United States is met by a combination of natural gas production, underground gas storage, imported gas, and supplemental gaseous fuels. Unpredictable market forces affect the number of new well completions and recompletions, which are related to drilling activity and rig efficiency. These forces include prices for oil and gas, imports, gas storage, regulatory changes, market dynamics, and total system deliverability.

This report addresses these concerns for the natural gas production element of total demand by presenting a historical analysis of the monthly productive capacity of natural gas at the wellhead for 1985 through 1995 and projecting productive capacity for 1996 and 1997. The impact of drilling, well completions, oil and gas price assumptions, and demand on gas productive capacity are integrated into the capacity projections as low, base, and high cases to account for the unpredictable market forces.

The base case reflects what would most likely occur if current market trends continue and drilling and production levels perform as they have in the past. The high case reflects an increase in the amount of drilling and favorable market conditions, while the low case reflects a decrease in drilling due to less favorable market conditions.

Assumptions used in the Wellhead Productive Capacity Model are summarized as follows:

- Wellhead gas productive capacity is a function of drilling, which adds new capacity, and production, which lowers existing capacity over time.

- The number of new gas-well completions is a function of drilling, which is influenced by oil and gas prices and production.

- Abandonment of individual conventional and coalbed gas-well completions is captured by decline functions for the group of wells included in a given vintage year for each area.

- Producing characteristics of new conventional and coalbed gas-well completions can be modeled from the characteristics of historical completions.

- Oil-well completions are currently producing at full capacity; therefore, the oil-well gas production rate equals oil-well gas capacity.

- U.S. gas production requirements are allocated to the lower 48 producing areas by month on the basis of 1994's production market share.

This report is based on of historical gas-well drilling and production data from State, Federal, and private sources. In addition to conventional gas-well gas, coalbed gas and oil-well gas are also included. Natural gas production from Alaska is excluded from this report because Alaskan gas does not enter the lower 48 States pipeline system.

For this report, monthly gas-well production data were as obtained on a per completion basis for 14 States and the Gulf of Mexico Outer Continental Shelf (OCS) from Dwight's EnergyData, Inc. (Dwight's). Dwight's data are not available for the entire lower 48 States. Production data on a State basis for the remaining States were obtained from EIA's Natural Gas Monthly reports, and the number of gas-well completions were obtained from the American Petroleum Institute (API) drilling statistics. Rig activity data for the Rig Model are obtained from Baker Hughes.

The method used to estimate natural gas productive capacity follows. Details of the methodology are found in Appendix A.

By use of monthly gas-well production data, wells are grouped by vintage (the year a well first produced) for each State or area. A monthly peak production rate was selected each year for every vintage in each State or area. These data were input into the Wellhead Productive Capacity Model (Appendix B), where equation parameters were defined and a monthly productive capacity was estimated for each of the vintage years. Vintage-level capacities were summed to obtain the total capacities for each State or area. These were assumed to be the historical productive capacities. The model was used to project low, base and high case productive capacities for 1996 and 1997.

The projected gas production from the model was prorated by State and area on the basis of historical market share as follows. If scheduled gas-well gas production was less than gas-well gas productive capacity in a given State or area, the production 
required was set equal to the scheduled production. If the required scheduled gas-well gas production was greater than gas productive capacity in a given State or area, the production was set equal to productive capacity. When a State or area did not have adequate capacity to meet scheduled production, the unfilled capacity requirement was prorated to other States or areas that had surplus productive capacity. Surplus gas productive capacity occurs when the gas productive capacity is greater than and the scheduled gas production. 


\section{Gas Productive Capacity}

\section{Gas Capacity to Meet Lower 48 States Requirements}

The United States has sufficient dry gas productive capacity at the wellhead to meet forecast monthly production requirements through 1997 (Figure 1). Any potential shortfalls in States with surplus productive capacity could probably be met by transfers from those areas with a large surplus productive capacity, such as the Gulf of Mexico Outer Continental Shelf (OCS).

Dry gas is the type of gas generally transported by transmission systems and delivered to customers. Gross $g a s$ is the full stream volume, including all natural gas plant liquids and nonhydrocarbon gases but excluding lease condensate. In 1994, dry gas production represented 89 percent of the gross gas production in the lower 48 States (Figure 2).

For reporting and analysis, the lower 48 States were grouped into 10 separate producing States or areas on the basis of gas production volumes (Figure 3). Dry gas productive capacity was determined for each of these 10 areas. The quarterly gas production forecast in the Energy Information Administration (EIA), Short-Term Integrated Forecasting System, Fourth Quarter 1996 \{11\} was used to determine the lower 48 States' production. This production was prorated into the 10 areas on the basis of their historical market shares (Appendix A). The quarterly production was further prorated into monthly data. If a given area could not meet its historical market share of production, the unmet production requirements were prorated to areas with surplus productive capacity. It was assumed that the pipeline facilities exist to transport this additional production from another supply area to its end market. Recent historical production patterns were used to allocate the projected lower- 48 gas production requirements for 1996 and 1997 among States and areas (Figure 4). Appendix A contains a full description of the methodology used for this report.

Figure 1. Lower 48 States Dry Gas Monthly Production Rate and Wellhead Productive

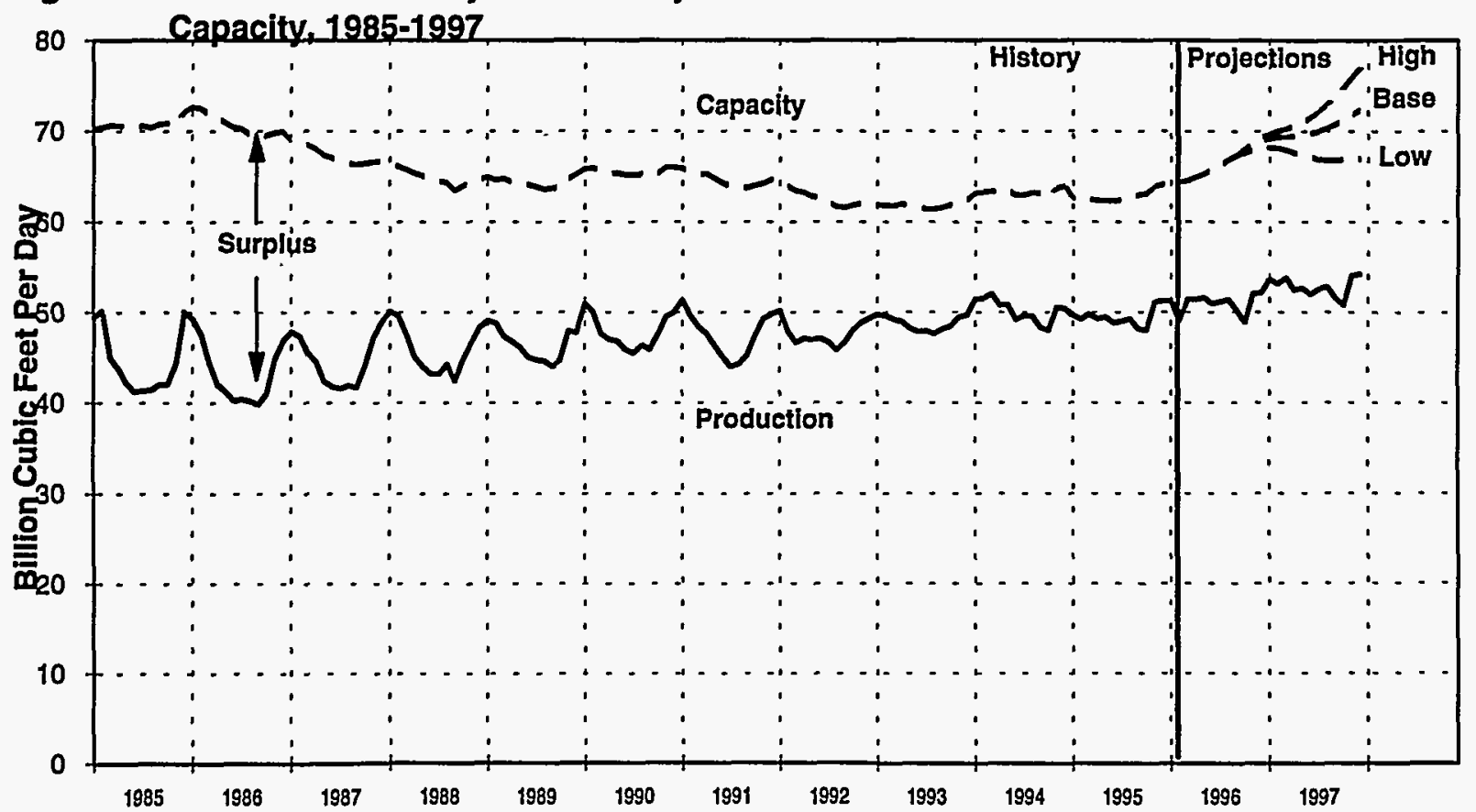

Note: Production projection plotted for base case only. The 1995 estimated history is based on Model GASCAP94 C110196 projections.

Sources: Production History; Energy Information Administration, Office of Oil and Gas; Dwight's Energydata, Inc.; and Model GASCAP94 C110196. Productive Capacity: Model GASCAP94 C110198. Production Projections: Energy Information Administration, Short-Term Integrated Forecasting System, Fourth Quarter 1998, and Model GASCAP94 C110196. 
Figure 2. Lower 48 States Natural Gas Production, 1985-1994

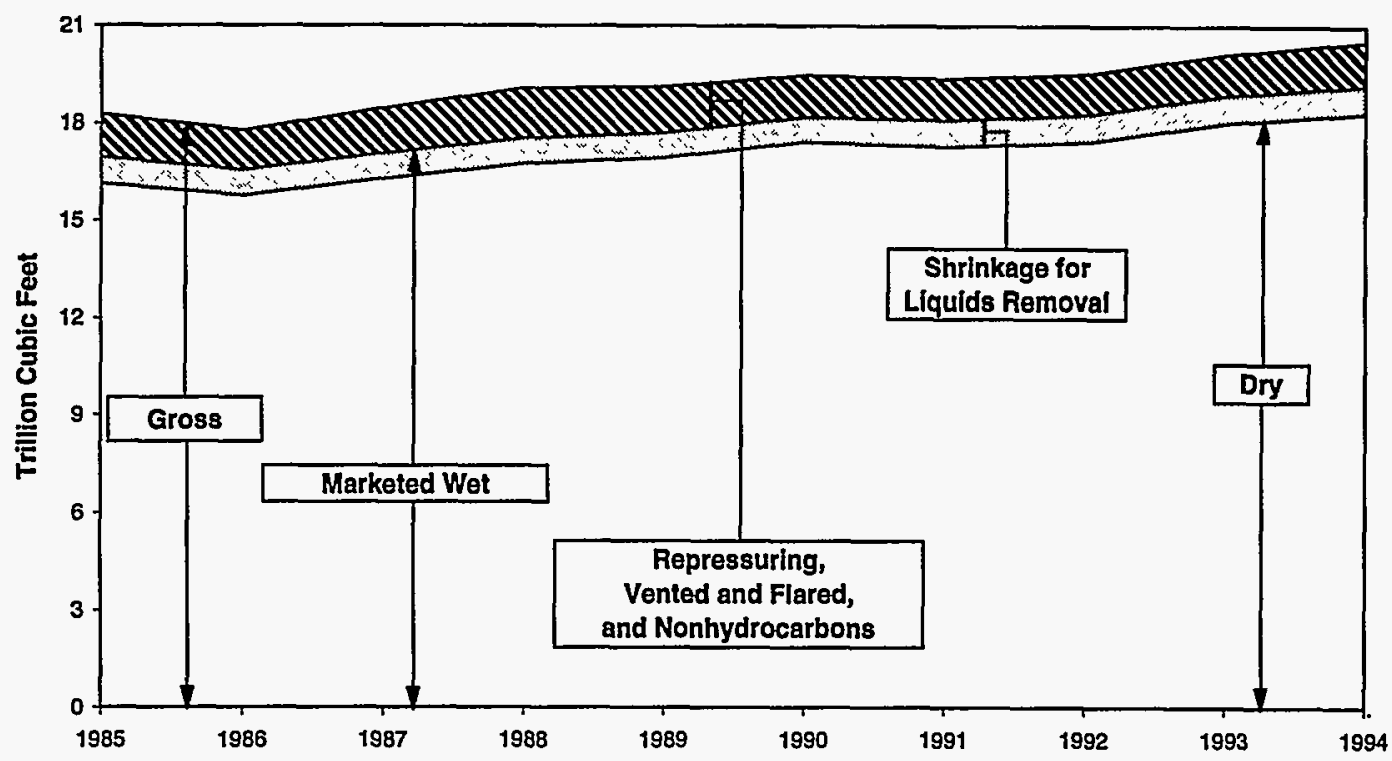

Source: Energy Information Administration, Natural Gas Annual, DOE/ElA-0131, 1985-1994.

Figure 3. Lower 48 States - Producing States and Areas

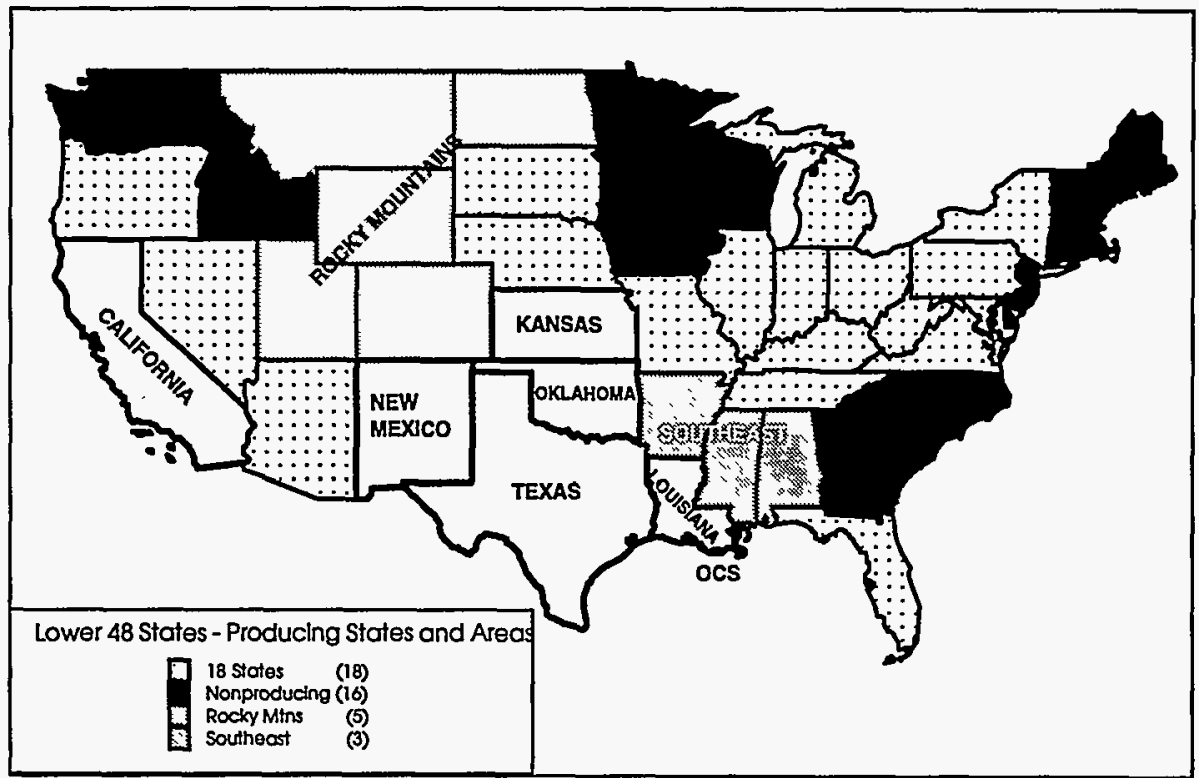

Note: The 18 States are Arizona, Florida, Illinois, Indiana, Kentucky, Maryland, Michigan, Missouri, Nebraska, Nevada, New York, Ohio, Oregon, Pennsyivania, South Dakota, Tennessee, Virginia, and West Virginía. Non-producing States are Connecticut, Georgia, Delaware, Idaho, lowa, Maine, Massachusetts, Minnesola, New Jersey, New Hampshire, North Carolina, Rhode Island, South Carolina, Vermont, Washington, and Wisconsin. Rocky Mountain States are Colorado, Montana, North Dakota, Utah, and Wyoming. Southeast States are Alabama, Arkansas, and Mississippi.

Source: Energy Information Administration, Office of Oil and Gas. 
Figure 4. Lower 48 States Productive Capacity and Supply Schematic

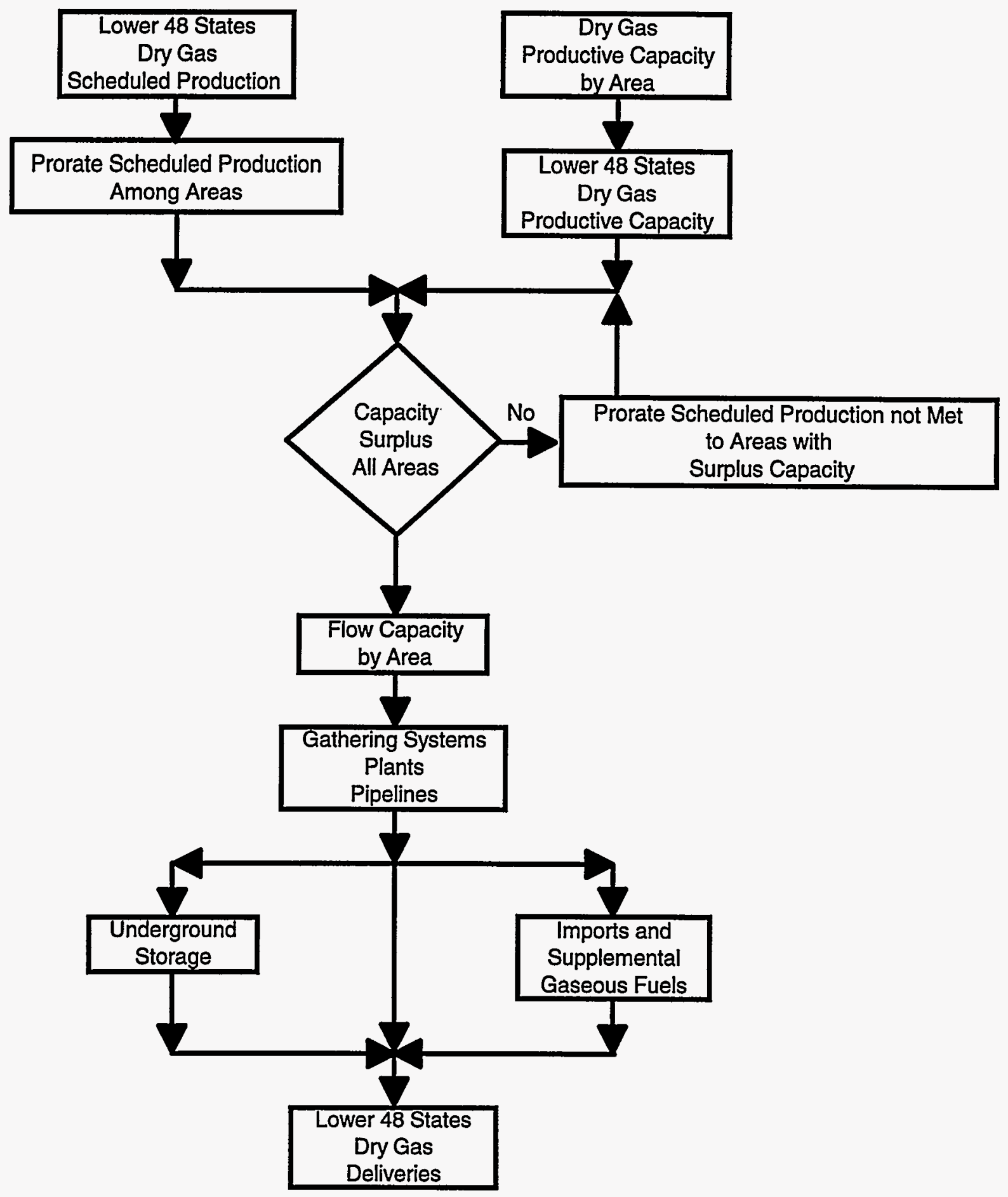

Source: Energy Information Administration, Office of Oil and Gas. 


\section{Historical Data}

\section{Dry Gas Productive Capacity Trends}

Historical monthly gas production and productive capacity for the lower 48 States for the months of January, June, and December are presented in Table 1. ${ }^{1}$ January and December represent the typical peak winter months, and June represents a non-heating season.

Dry gas productive capacity in the lower 48 States substantially exceeded production throughout the 1980 's. The lower 48 States' surplus capacity was more than 20 billion cubic feet per day through December 1986. However, gas capacity began declining in 1986 as drilling and new well completions rapidly declined. In 1995, surplus capacity was 12.9 billion cubic feet per day in December of that year.

The rapid decline in drilling and new well completions was caused by reduced prices. The wellhead price for natural gas declined from 1985 to 1986 and then began fluctuating seasonally after 1987 (Figure 5).

\section{Gas Production}

Total gross gas production (composed of gas-well and oil-well gas) from 1985 through 1994 is shown in Figure 6. Gas production from oil wells was stable over this time period, although oil production declined. Increases in producing gas-oil ratios roughly compensated for the declines in oil production. In 1994, gas production from oil wells was 16 percent of total gas production in the lower 48 States. If oil production declines in 1995, 1996, and 1997, as expected, gas production from oil wells will also decline if the producing gas-oil ratio stays at its 1994 level. The share of total gross production from gas wells increased from 79 percent in 1986 to 84 percent in 1994

The dry natural gas production contribution from the major gas-producing States and areas is shown by Figure 7. The market share of production among States has been fairly stable from 1985 through 1994 . The two largest gas-producing areas are the Gulf of Mexico OCS and Texas. Together these areas produce over one-half of the dry gas in the lower 48 States. The Gulf of Mexico has made the largest contribution to meeting major seasonal swings in demand. Other significant natural gas-producing States include Oklahoma, Louisiana, New Mexico, and Kansas. Chapter 3 reviews State and area gas production in detail.

${ }^{1}$ Production and capacity for all 12 months can be obtained from the authors.
Monthly gas production varies seasonally. Normally, production is highest in the months of January or February (because of high heating demand), substantially lower in June, and relatively higher in December. However, the minimum monthly production rate for a given year may fall in other months, such as September, when there is neither a large cooling nor heating demand.

Coalbed gas was treated separately in this report for New Mexico and the Southeast and Rocky Mountains areas (Figure 8). These are the three major coalbed gasproducing areas. Coalbed gas production has increased 1 percent per year as a percentage of the lower 48 States $^{\prime}$ gas production since 1990. Coalbed gas production was 5 percent of the lower-48 total gas produced in 1994.

\section{Gas Prices}

The average real wellhead value of natural gas peaked in 1983 at $\$ 3.75$ (in constant 1994 dollars) per thousand cubic feet $\{12\}$, dropped sharply in 1986, and continued to decline to $\$ 1.76$ per thousand cubic feet in 1991 (a 53 percent drop over eight years). The average price increased in 1994 to $\$ 1.88$. (13) For comparison, real domestic crude oil prices dropped from $\$ 37.87$ per barrel in 1983 to $\$ 13.19$ in 1994, a 65 percent drop.\{12\} Given the lower prices and consequent decrease in drilling, it is understandable that wellhead productive capacity declined to values closer to gas production requirements from 1986 through 1994.

\section{Projections}

\section{Dry Gas Productive Capacity and Production}

EIA projects the natural gas wellhead productive capacity for the lower 48 States by using the Wellhead Productive Capacity Model. For a description of the model and its methodology, see Appendix $B$. The model estimates the last year of historical production and productive capacity and generates a 2-year projection of production and well head gas capacity. To account for unpredictable market forces and changing drilling activity levels, gas productive capacity projections are formulated for low, base, and high cases. The base case reflects what would most likely occur if current market trends continue and drilling and production levels continue to perform as they have performed in the past. The high case reflects an increase in the amount of drilling under more favorable market conditions, while 
Table 1. Lower 48 States Dry Gas Production and Wellhead Productive Capacity, 1985-1995 (Billion Cubic Feet Per Day)

\begin{tabular}{|c|c|c|c|c|c|c|}
\hline \multirow[b]{2}{*}{ Month-Year } & \multirow[b]{2}{*}{$\begin{array}{c}\text { Dry } \\
\text { Production }\end{array}$} & \multicolumn{5}{|c|}{ Dry Gas Productive Capacity } \\
\hline & & $\begin{array}{c}\text { Gas-Well } \\
\text { Gas }\end{array}$ & $\begin{array}{c}\text { Oil-Well } \\
\text { Gas }\end{array}$ & $\begin{array}{l}\text { Total } \\
\text { Gas }\end{array}$ & $\begin{array}{c}\text { Total } \\
\text { Surplus }\end{array}$ & $\begin{array}{l}\text { Utilization } \\
\text { (percent) }\end{array}$ \\
\hline Jan-85 & 49.5 & 61.3 & 9.0 & 70.3 & 20.8 & 70.5 \\
\hline Jun-85 & 41.2 & 61.3 & 9.2 & 70.4 & 29.2 & 58.5 \\
\hline Dec-85 & 50.1 & 62.9 & 9.2 & 72.1 & 22.1 & 69.4 \\
\hline Jan-86 & 49.3 & 62.8 & 9.8 & 72.6 & 23.3 & 67.9 \\
\hline Jun-86 & 40.3 & 61.4 & 9.0 & 70.4 & 30.2 & 57.2 \\
\hline Dec-86 & 46.9 & 61.1 & 8.8 & 70.0 & 23.0 & 67.1 \\
\hline Jan-87 & 47.9 & 60.1 & 9.0 & 69.1 & 21.2 & 69.3 \\
\hline Jun-87 & 41.8 & 58.2 & 8.8 & 67.0 & 25.3 & 62.3 \\
\hline Dec-87 & 49.0 & 58.0 & 8.7 & 66.6 & 17.6 & 73.6 \\
\hline Jan-88 & 50.1 & 57.6 & 8.8 & 66.4 & 16.3 & 75.4 \\
\hline Jun-88 & 43.2 & 56.0 & 8.8 & 64.8 & 21.6 & 66.7 \\
\hline Dec-88 & 48.4 & 56.1 & 8.5 & 64.7 & 16.3 & 74.8 \\
\hline Jan-89 & 49.1 & 56.2 & 8.8 & 64.9 & 15.8 & 75.6 \\
\hline Jun-89 & 45.0 & 55.7 & 8.4 & 64.1 & 19.1 & 70.3 \\
\hline Dec-89 & 47.8 & 57.4 & 7.9 & 65.3 & 17.5 & 73.2 \\
\hline Jan-90 & 50.9 & 57.2 & 8.7 & 65.9 & 14.9 & 77.3 \\
\hline Jun-90 & 45.8 & 56.8 & 8.4 & 65.2 & 19.3 & 70.3 \\
\hline Dec-90 & 50.0 & 57.6 & 8.4 & 66.0 & 16.0 & 75.8 \\
\hline Jan-91 & 51.3 & 57.5 & 8.4 & 65.9 & 14.6 & 77.9 \\
\hline Jun-91 & 45.1 & 56.0 & 8.3 & 64.3 & 19.2 & 70.1 \\
\hline Dec-91 & 49.8 & 56.4 & 8.3 & 64.7 & 14.9 & 77.0 \\
\hline Jan-92 & 50.2 & 55.7 & 8.6 & 64.3 & 14.1 & 78.1 \\
\hline Jun-92 & 47.1 & 54.2 & 8.4 & 62.6 & 15.5 & 75.3 \\
\hline Dec-92 & 49.3 & 53.9 & 8.2 & 62.1 & 12.8 & 79.5 \\
\hline Jan-93 & 49.8 & 53.7 & 8.1 & 61.9 & 12.1 & 80.5 \\
\hline Jun-93 & 47.9 & 53.5 & 8.1 & 61.6 & 13.8 & 77.6 \\
\hline Dec-93 & 49.7 & 54.5 & 7.9 & 62.4 & 12.7 & 79.7 \\
\hline Jan-94 & 51.5 & 55.1 & 8.0 & 63.2 & 11.7 & 81.4 \\
\hline Jun-94 & 49.2 & 55.1 & 7.9 & 63.0 & 13.8 & 78.1 \\
\hline Dec-94 & 50.5 & 56.0 & 8.0 & 64.0 & 13.5 & 78.9 \\
\hline Jan- $95^{\prime \prime}$ & 49.6 & 54.7 & 7.9 & 62.6 & 13.0 & 79.3 \\
\hline Jun-95 & 48.8 & 54.4 & 7.9 & 62.3 & 13.5 & 78.4 \\
\hline Dec-95" & 51.2 & 56.4 & 7.7 & 64.1 & 12.9 & 79.9 \\
\hline
\end{tabular}


Figure 5. Natural Gas Price by Category, 1985-1994

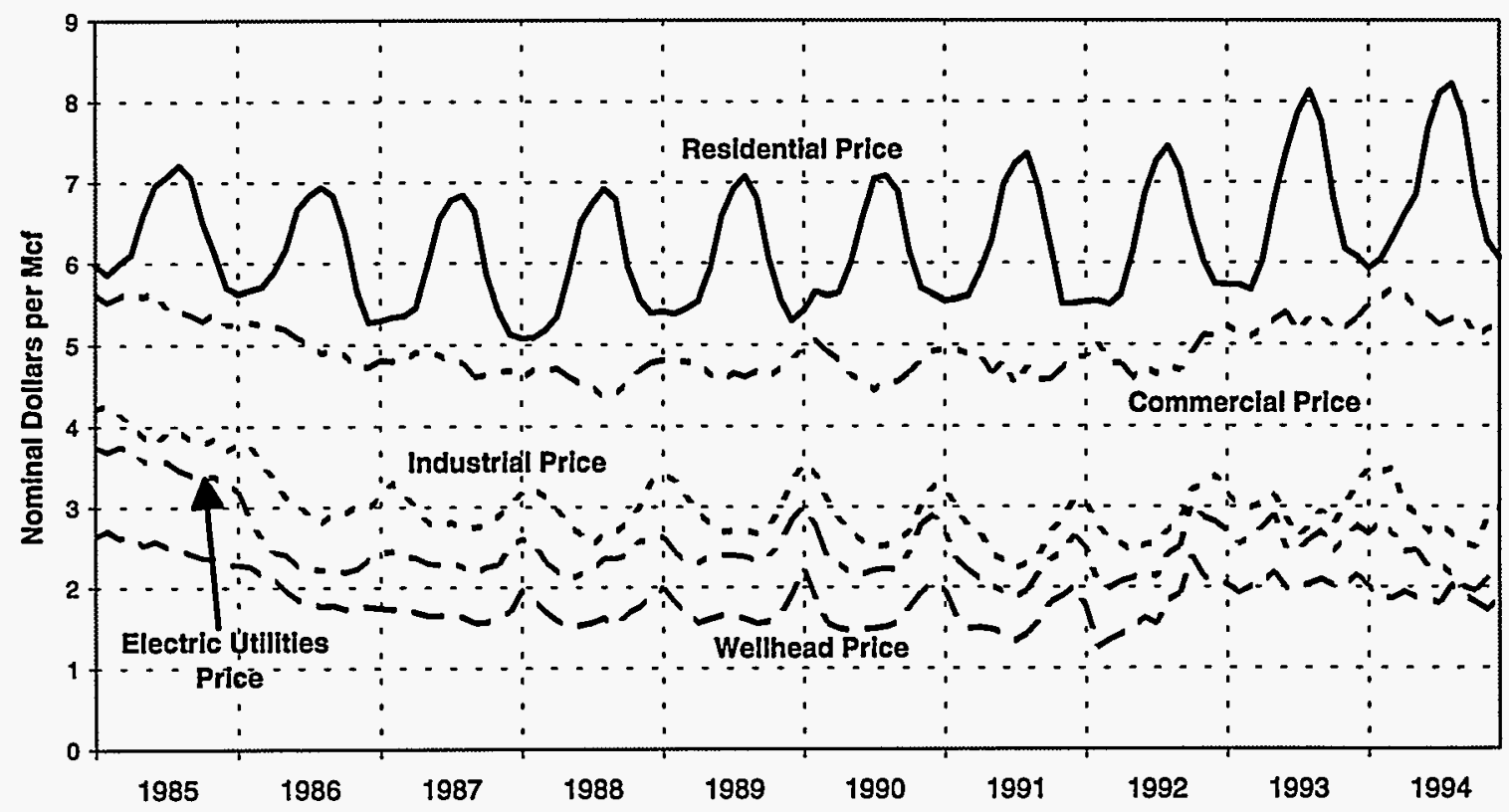

Source: Energy Information Administration, Natural Gas Monthly, DOE/EIA-0130(96/02).

Figure 6. Lower 48 States Gross Natural Gas Production by Type, 1985-1994

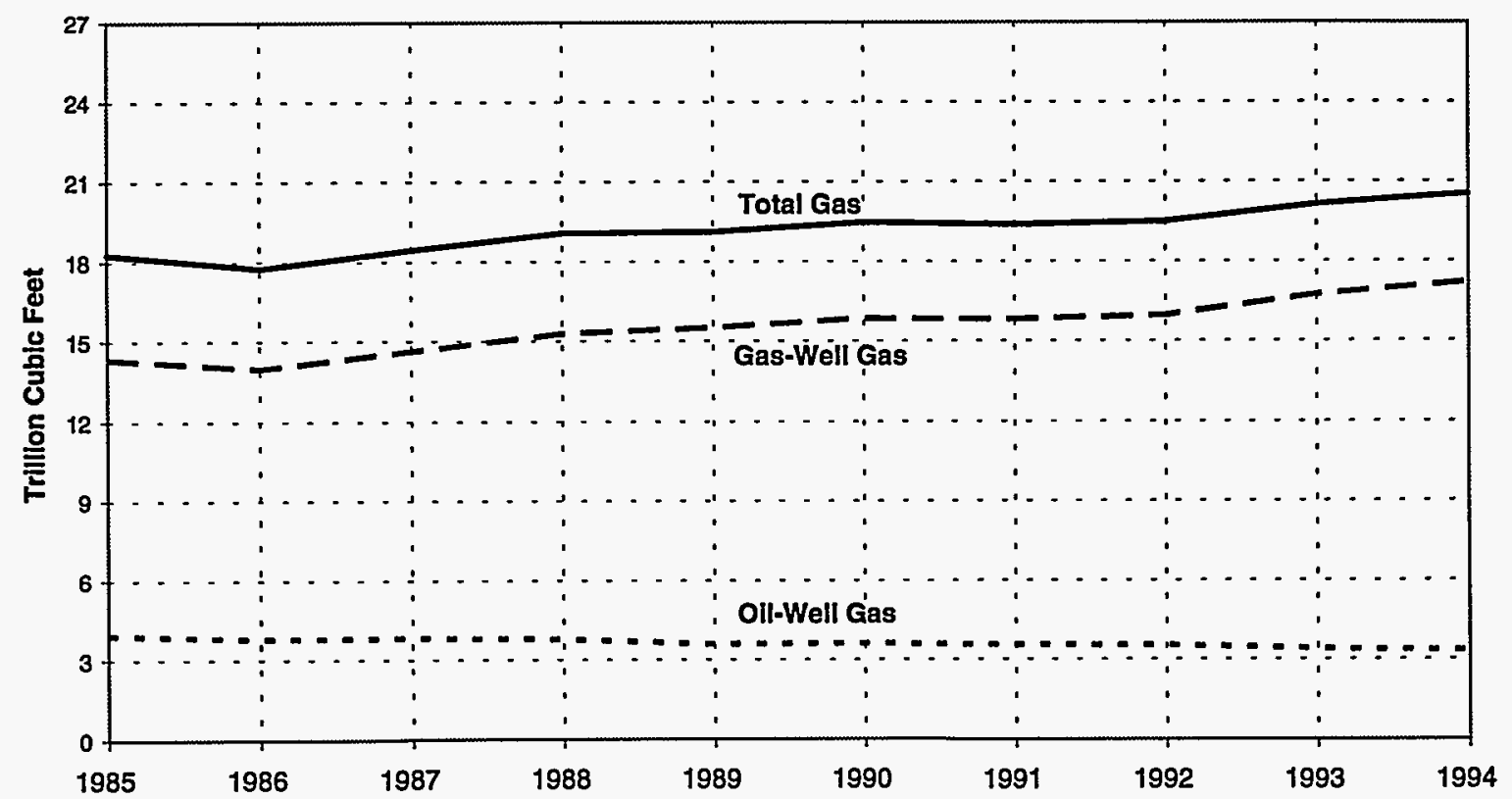

Source: Energy Information Administration, Natural Gas Annual, DOE/EIA-0131, 1985-1994. 
Figure 7. Dry Natural Gas Production from Lower 48 Producing States, 1985-1994

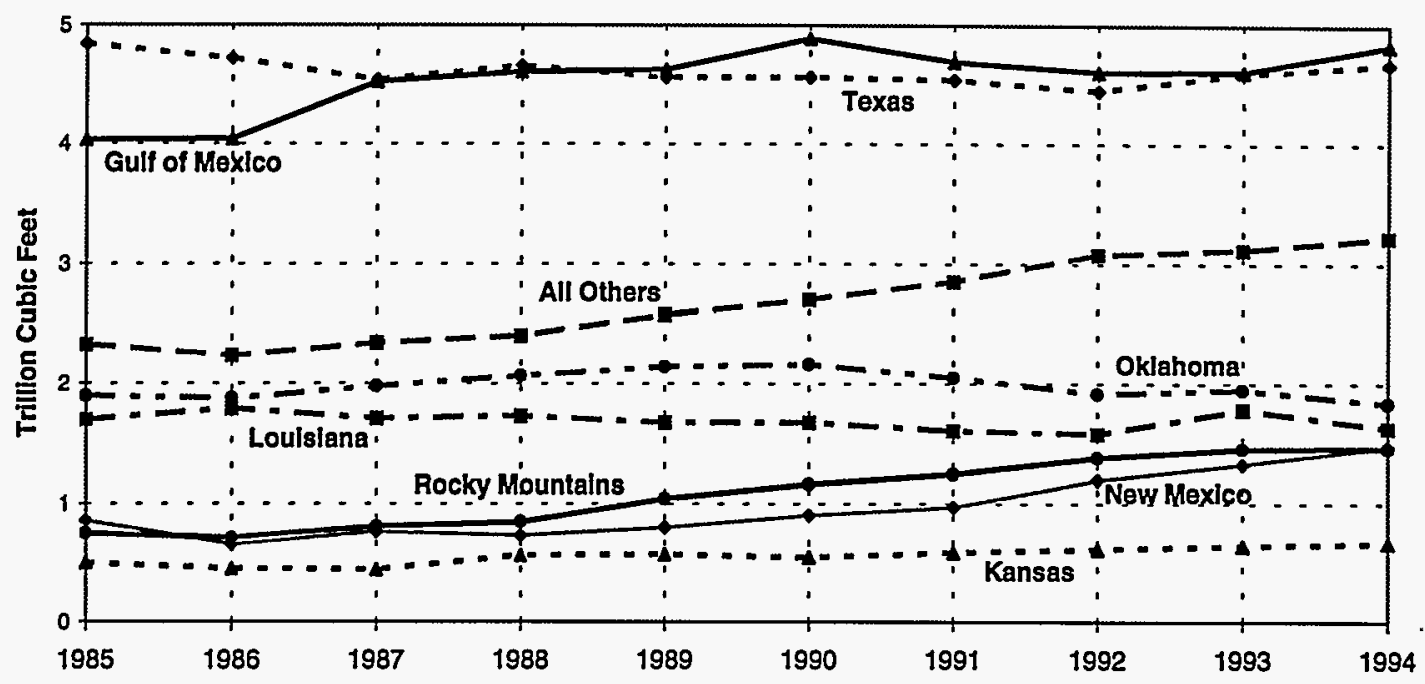

Note: State production for Texas and Louisiana does not include Gulf of Mexico OCS production

Sources: Energy Information Administration, Natural Gas Annual, DOE/EIA-0131, 1985-1994. Data for Texas, Louisiana, and Gulf of Mexico OCS are from Energy Information Administration, Office of Oil and Gas.

Figure 8. Lower 48 States Dry Coalbed Gas Monthly Production Rate and Wellhead Productive Capacity, 1985-1997

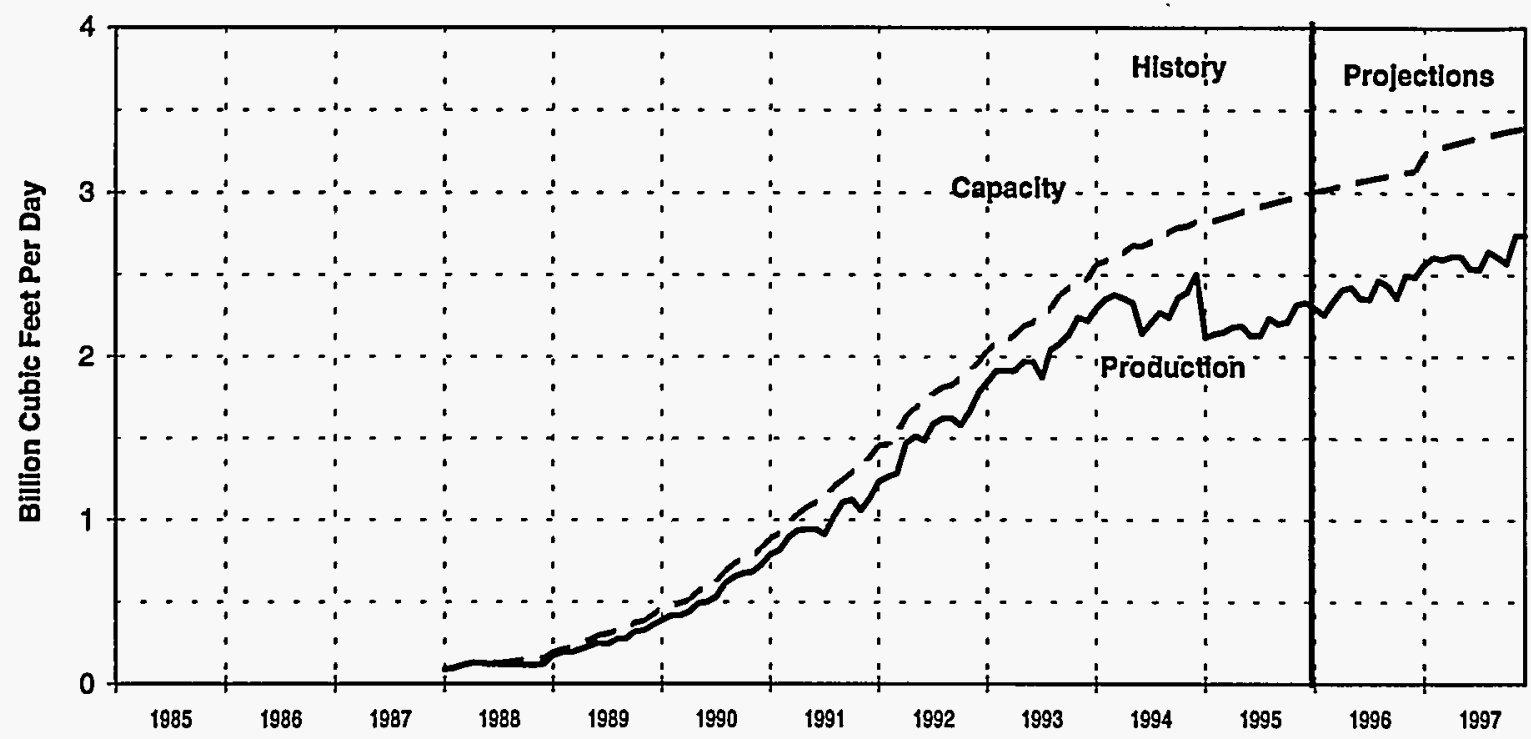

Note: Production projection plotted for base case only.

Sources: Production History: Energy Information Administration, Office of Oll and Gas; Dwight's Energydata, Inc.; and Model GASCAP94 C110196. Productive Capacity: Model GASCAP94 C11016. Production Projections: Energy Information Administration, Short-Term Integrated Forecasting System, Fourth Quarter 1996, and Model GASCAP94 C110196. 
the low case reflects a decrease under less favorable conditions. The model results are listed in Table 2.

In December 1995, the wellhead productive capacity of the lower 48 States was 64.1 billion cubic feet per day of dry natural gas. For the lower 48 States, the model projects the following:

- In the low case projection, dry gas productive capacity will increase 5 percent to 67.0 billion cubic feet per day in December 1997.

- In the base case projection, productive capacity will increase 13 percent to 72.3 billion cubic feet per day in December 1997.

- In the high case, productive capacity increases 20 percent from the December 1995 level, reaching 77.0 billion cubic feet per day in December 1997.

For surplus capacity in the lower 48 States:

- In the low case, the surplus capacity declines from 12.9 billion cubic feet per day in December 1995 to 12.7 billion cubic feet per day in December 1997.

- In the base case, surplus capacity increases to 18.1 billion cubic feet per day in December 1997.

- In the high case, the surplus capacity increases to 22.7 billion cubic feet per day in December 1997.

Gas productive capacity should be adequate to meet the projected monthly gas production requirements of the lower 48 States through December 1997, even in the low case.

\section{New Well Completions}

Gas productive capacity is increased by new gas-well completions. If there had been no new gas-well completions projected after 1994, the surplus capacity would have gone from 12.9 billion cubic feet per day in December 1995 to zero by December 1996. With no new completions, productive capacity would not have been adequate to meet the forecast production requirements. Gas-well completions must be added continuously to sustain an adequate productive capacity.

To project gas productive capacity, a projection of new gas-well completions is required. The projection of new well completions is based on a projection of rigs running and an estimate of completions per rig. Forecasts of the total drilling rigs were obtained from the EIA Drilling Rig Model. This model generates monthly rig counts on the basis of oil and gas revenues which are derived from production and price data appearing in the EIA's Short Term Energy Outlook (STEO). The Drilling Rig Model is described in Appendix A.

Gas-well completions dropped from 17,639 in 1985 to 11,356 in 1986, with even fewer completions in 1987 (Figure 9). Despite this large decline, the general improvement in the average productive capacity of new completions precluded a serious loss of surplus capacity (Figure 1).

Gas-well completions added for the 2-year period 1996 through 1997 are estimated to be 21,694 for the low case, 25,451 for the base case, and 28,752 for the high case (Figure 9). The larger number of completions yields a dry gas productive capacity for the high case in December 1997 that is 77.0 billion cubic feet per day, (Table 2) or 7 percent higher than the 72.3 billion cubic feet per day in the base case. Gas production requirements were assumed to be the same in both cases.

A new gas-well completion is estimated to add about one million cubic feet per day of capacity (Appendix D). For the low case in 1997, the gas-well gas productive capacity is estimated to decline about 1.0 billion cubic feet per day (December 1996 to December 1997). To avert this decline, 1,000 gas-well completions need to be brought on production in 1997.

For the low, base, and high cases, the corresponding gas-well completions were estimated primarily as a function of gas price and production. The 1997 gas prices for the three cases were respectively $\$ 1.72, \$ 1.85$, and $\$ 2.15$ per thousand cubic feet, as shown in the Short-Term Integrated Forecasting System, Fourth-Quarter 1996\{11\}. The actual gas prices were $\$ 1.88$ per thousand cubic feet in 1994\{13\} and \$1.59 in 1995\{11\}.

The newer gas-well completions contribute most of the productive capacity in the lower 48 States. Wells less than three years old contributed 42 percent of the productive capacity in the lower 48 States in December 1994. Wells less than 2 years old provided 35 percent, while wells completed that year provided 22 percent (Figure 10). 
Table 2. Lower 48 States Dry Gas Production and Wellhead Productive Capacity Projections: 1996-1997 (Billion Cubic Feet Per Day)

\begin{tabular}{|c|c|c|c|c|c|c|}
\hline \multirow[b]{2}{*}{ Month-Year } & \multirow[b]{2}{*}{$\begin{array}{c}\text { Dry } \\
\text { Production } \\
\end{array}$} & \multicolumn{5}{|c|}{ Dry Gas Productive Capacity } \\
\hline & & $\begin{array}{c}\text { Gas-Well } \\
\text { Gas }\end{array}$ & $\begin{array}{c}\text { Oil-Well } \\
\text { Gas }\end{array}$ & $\begin{array}{l}\text { Total } \\
\text { Gas } \\
\end{array}$ & $\begin{array}{c}\text { Total } \\
\text { Surplus } \\
\end{array}$ & $\begin{array}{l}\text { Utilization } \\
\text { (percent) }\end{array}$ \\
\hline & \multicolumn{6}{|c|}{ Low Case Projection } \\
\hline Jan-96 & 51.2 & 56.5 & 7.8 & 64.2 & 13.0 & 79.8 \\
\hline Jun-96 & 50.9 & 58.0 & 7.8 & 65.8 & 14.8 & 77.4 \\
\hline Dec-96 & 52.2 & 60.7 & 7.6 & 68.4 & 16.2 & 76.3 \\
\hline Jan-97 & 53.6 & 60.6 & 7.6 & 68.2 & 14.6 & 78.6 \\
\hline Jun-97 & 52.0 & 59.8 & 7.4 & 67.2 & 15.2 & 77.3 \\
\hline \multirow[t]{2}{*}{ Dec-97 } & 54.2 & 59.7 & 7.3 & 67.0 & 12.7 & 81.0 \\
\hline & \multicolumn{6}{|c|}{ Base Case Projection } \\
\hline Jan-96 & 51.2 & 56.5 & 7.8 & 64.2 & 13.0 & 79.8 \\
\hline Jun-96 & 50.9 & 58.0 & 7.8 & 65.8 & 14.8 & 77.4 \\
\hline Dec-96 & 52.2 & 61.1 & 7.8 & 69.0 & 16.8 & 75.6 \\
\hline Jan-97 & 53.6 & 61.3 & 7.8 & 69.1 & 15.5 & 77.5 \\
\hline Jun-97 & 52.0 & 62.0 & 7.7 & 69.7 & 17.7 & 74.5 \\
\hline \multirow[t]{2}{*}{ Dec-97 } & 54.2 & 64.6 & 7.7 & 72.3 & 18.1 & 75.0 \\
\hline & \multicolumn{6}{|c|}{ High Case Projection } \\
\hline Jan-96 & 51.2 & 56.5 & $\overline{7.8}$ & 64.2 & 13.0 & 79.8 \\
\hline Jun-96 & 50.9 & 58.0 & 7.8 & 65.8 & 14.8 & 77.4 \\
\hline Dec-96 & 52.2 & 61.3 & 8.0 & 69.3 & 17.2 & 75.3 \\
\hline Jan-97 & 53.6 & 61.6 & 8.0 & 69.6 & 16.0 & 77.0 \\
\hline Jun-97. & 52.0 & 63.5 & 8.0 & 71.5 & 19.5 & 72.7 \\
\hline Dec-97 & 54.2 & 69.0 & 8.0 & 77.0 & 22.7 & 70.5 \\
\hline
\end{tabular}

Sources: Production Projections: Energy Information Administration, Short-Term Integrated Forecasting System, Fourth Quarter 1996 and Model GASCAP94 C110196. Productive Capacity Projections: Model GASCAP94 C110196.

\section{Gas Productive Capacity Issues}

\section{Demand}

Peak-day demand may be twice the annual average-day demand. Peak-day demand usually occurs in December, January, or February during very cold weather. The cold weather, while increasing gas demand, may also decrease potential supply because of weather-related production and transportation problems. $^{2}$
Peak-day demand cannot be met by increasing gas production at the wellhead and should not be expected to be met by production in the future. The National Petroleum Council \{14\} estimated that firm peak-day consumption in 1991 reached 102 billion cubic feet per day. The period from December 23 to December 27, 1989, was extraordinarily cold and demand may well have approached this peak rate.

To better serve its customers, the natural gas industry has developed methods to meet peak demand, such as delivery from gas storage facilities $(70$ billion cubic feet per day) $\{15\}$ and peak shaving facilities ( 3 billion cubic feet per day). $\{14\}$ Some projects have recently been

\footnotetext{
${ }^{2}$ For more information about this subject see Energy Information Administration, Service Report SR/OG/91-01 and Oil and Gas Journal, March 5, 1990, pp.17-20.
} 
Figure 9. Lower 48 States Gas-Well Completions Added During Year, 1985-1997

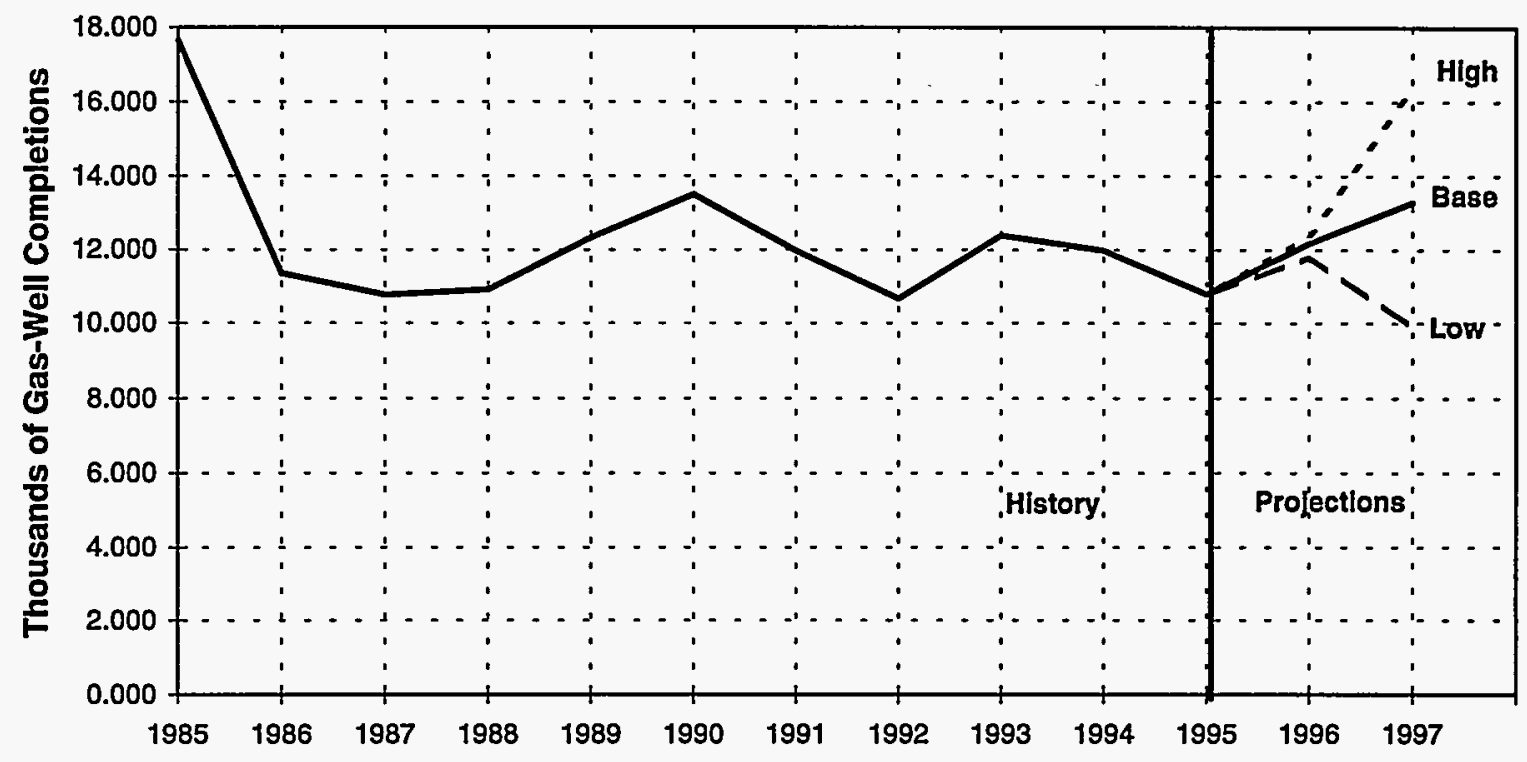

Note: The 1995 estimated history is based on EIA's Drilling Rig Model projections and Baker Hughes rig counts. Completions Include recompletions in new producing zones.

Sources: History: Energy Information Administration, Office of Oil and Gas; Dwight's Energydata, Inc. Projectlons: Model GASCAP94 C110196.

Table 10. California (Including Pacific OCS) Dry Gas Production and Wellhead Productive Capacity Projections, 1996-1997 (Million Cubic Feet Per Day)

\begin{tabular}{|c|c|c|c|c|c|c|}
\hline \multirow[b]{2}{*}{ Month-Year } & \multirow[b]{2}{*}{$\begin{array}{c}\text { Dry } \\
\text { Production }\end{array}$} & \multicolumn{5}{|c|}{ Dry Gas Productive Capaclty } \\
\hline & & $\begin{array}{c}\text { Gas-Well } \\
\text { Gas }\end{array}$ & $\begin{array}{c}\text { Oll-Well } \\
\text { Gas }\end{array}$ & $\begin{array}{c}\text { Total } \\
\text { Gas }\end{array}$ & $\begin{array}{c}\text { Total } \\
\text { Surplus }\end{array}$ & $\begin{array}{l}\text { Utillzatlon } \\
\text { (percent) }\end{array}$ \\
\hline & \multicolumn{6}{|c|}{ Low Case Projection } \\
\hline Jan-96 & 851 & 334 & 598 & 932 & 81 & 91.3 \\
\hline Jun-96 & 804 & 333 & 609 & 942 & 138 & 85.4 \\
\hline Dec-96 & 891 & 341 & 591 & 932 & 41 & 95.6 \\
\hline Jan-97 & 900 & 335 & 585 & 920 & 20 & 97.8 \\
\hline Jun-97 & 829 & 318 & 571 & 889 & 60 & 93.3 \\
\hline \multirow[t]{2}{*}{ Dec-97 } & 859 & 303 & 556 & 859 & 0 & 100.0 \\
\hline & \multicolumn{6}{|c|}{ Base Case Projection } \\
\hline Jan-96 & 851 & 334 & 598 & 932 & 81 & 91.3 \\
\hline Jun-96 & 804 & 333 & 609 & 942 & 138 & 85.4 \\
\hline Dec-96 & 891 & 344 & 601 & 945 & 54 & 94.3 \\
\hline Jan-97 & 899 & 340 & 599 & 939 & 40 & 95.7 \\
\hline Jun-97 & 829 & 331 & 592 & 923 & 94 & 89.8 \\
\hline \multirow[t]{2}{*}{ Dec-97 } & 916 & 330 & 586 & 916 & 0 & 100.0 \\
\hline & \multicolumn{6}{|c|}{ High Case Projection } \\
\hline Jan-96 & 851 & 334 & 598 & 932 & 81 & 91.3 \\
\hline Jun-96 & 804 & 333 & 609 & 942 & 138 & 85.4 \\
\hline Dec-96 & 890 & 345 & 610 & 955 & 65 & 93.2 \\
\hline Jan-97 & 899 & 342 & 613 & 955 & 56 & 94.1 \\
\hline Jun-97 & 829 & 343 & 609 & 952 & 123 & 87.1 \\
\hline Dec-97 & 918 & 360 & 609 & 969 & 51 & 94.7 \\
\hline
\end{tabular}


placed in service and others are proposed that allow greater access to supply areas and support increasing natural gas consumption.

It could be argued that in periods of high gas demand, price increases at the wellhead could both increase supply quantities and decrease consumption until they balance. Over a sufficient period of time this is true. However, in the very short term (days), average wellhead prices are relatively unresponsive to demand, although, commercial, industrial, and electric utility gas prices normally increase during periods of high seasonal demand (Figure 5). The vast majority of gas is covered by 30 -day or longer contracts. Therefore, if there is a sudden large increase in gas demand, there is not an accompanying sudden, large increase in the average price of gas at the wellhead. However, small volumes of gas may sell at very high prices on the spot market.

Effective gas demand in peak periods is typically lowered by reducing deliveries to customers with interruptible contracts or by customers with fuel-switching capability responding to higher gas prices by switching to another fuel. A price increase would have little impact on reducing residential gas requirements. It is residential heating or cooling demand that is most likely to have a sudden upward surge related to weather. Residential consumers used 5.9 times as much gas in December 1993 as they did in August 1993 and 5.2 times as much gas in December 1994 as they did in August 1994.\{16\}

Because cost-of-service pricing lowers the unit cost of gas during periods when large volumes are being delivered, the residential cost of gas per thousand cubic feet actually drops in December, while the wellhead price of gas increases.\{16\} Figure 5 shows the relationship of wellhead price to residential, commercial, industrial, and electric utility prices for 1985 through 1994. Therefore, small increases in the average price of natural gas at the wellhead do not effectively dampen weather-related residential gas requirements in the short term.

\section{Deliverability}

The existence of a high gas productive capacity at the wellhead does not mean that it could actually be produced and delivered. Deliverability is always equal to or less than wellhead productive capacity. Deliverability takes into account restrictions imposed by pipeline capacity, contract, or regulatory bodies.
Even with a large surplus dry gas productive capacity, there can be short-term regional gas supply problems such as occurred in December 1983 and December 1989. ${ }^{3}$

In order to meet peak-month or peak-day demand, the pipeline system must also have adequate deliverability to the final destination. Pipeline systems must have adequate diameters, properly spaced compressors, and adequate interconnections between pipelines. Gas pipeline systems must be optimized to transport gas efficiently from any well to wherever in the lower 48 States where the need might arise.

Productive capacity and deliverability can be compared by using the data collected by the Natural Gas Supply Association (NGSA) in its NGSA Survey on 1995 Natural Gas Field Deliveries \& Productive Capacity. $\{17\}$ The data on connected gas-well capacity as of January 1, 1995, which is equivalent to deliverability into the pipeline system, were collected on an operator basis for seven lower- 48 regions. The survey covered 77 percent of the production for the Offshore Gulf Coast, the highest for any region in the survey. The ratio of the NGSA 1995 connected gas field capacity to the annual 1995 field deliveries was 1.09. In other words, deliverability was 9 percent higher than annual production. The equivalent deliverability for all Offshore Gulf Coast operators was 15 billion cubic feet per day if the NGSA surveyed operators are representative of all operators in this region.

For the month of January 1995, it was estimated that 87 percent of the productive capacity at the wellhead could be delivered into the pipeline system. This was obtained by dividing the January 1995 deliverability of 55 billion cubic feet per day (determined by scaling up the NGSA connected-gas-well capacity) $\{17\}$ by the January 1995 dry productive capacity at the wellhead of 63 million cubic feet per day.

During the 1980's and most recently with FERC Order 636 in 1992, major changes have occurred in regulations, contracts, interconnections between trunklines, access to transportation, and markets. These changes have introduced a much greater degree of flexibility and responsiveness in the natural gas industry. This flexibility makes it likely that a higher percentage of the productive capacity can be delivered. More gas can get from where it is produced to where it is needed. However, in some cases, pipeline capacity may limit gas deliverability.

\footnotetext{
${ }^{3}$ For more information on this subject see American Oil \& Gas Reporters. May 1984, pp. 15-25; Energy Informationa Administration, Service Report SR/OG/9/01; and Oil and Gas Journal, March 5, 1990, pp. 17-20.
} 


\section{Weather's Effect on Deliverability}

The December 1989 average-day production of dry gas was only 47.8 billion cubic feet per day (Table 1 ), which was practically the same as in December 1988. However, some regional peak-day requirements for production in late December 1989 were not met. Some customers with firm contracts had their gas supplies curtailed. This was in large part due to weather-related production problems that are not likely to soon occur again with the same severity. Weather-related increases in gas production requirements and decreases in supply also occurred in December 1983. In December 1983, the problems were most severe in south Texas. In December 1989, they were most severe in the Gulf of Mexico OCS.

One problem that is associated with the handling of natural gas is the phenomenon of a production line or well "freezing up." This problem occurs when water vapor and hydrocarbon vapors combine to form snow-like substances, called hydrates. Under suitable pressure conditions, hydrates may be formed at temperatures well above the freezing point of water. One of the problems in handling natural gas is the prevention of the formation of hydrates and their removal once formed.

The proper winterization of wells, pipelines, and gas processing facilities is a relatively straightforward and inexpensive process. Operators in south Texas prepared for severe weather after December 1983 and were not severely affected in December 1989.

Interruptions in regional supply can cause a peak production requirement in other areas. For example, a storm in the Gulf of Mexico OCS, such as hurricane Andrew in August 1992, damaged 243 producing sites in the Gulf. Some 5 percent of the Nation's gas supply, or about 2.5 to 2.75 billion cubic feet per day was abruptly shut in. A month and-a-half later, in early October, 750 to 800 million cubic feet of production was still shut in. Needed gas was supplied to consumers from other areas or from storage during part of this time.

\section{Gas Storage}

Gas storage is a vital part of the natural gas industry. Stored gas provides a source for reliable deliveries during periods of heavy demand. Storage also enables greater system efficiency by allowing more stable production and transmission flows.

Storage withdrawals and peak shaving were used successfully to prevent gas supply curtailment in the extraordinarily high peak-day demand period in December 1989. Sufficient dry gas productive capacity will exist during the years 1995 through 1997 to increase the underground natural gas storage inventory needed. Gas storage requirements can be met by maintaining gas production closer to gas productive-capacity throughout the year. Increased use of storage reduces the need for excess productive capacity, thus promoting improved economic efficiency in production.

\section{Imports}

Imports have become an increasingly important part of the domestic gas supply picture. Reliance on imported gas has more than doubled in less than a decade. In 1985, net imports made up 5 percent ( 894 billion cubic feet) of the total gas demand requirements. In 1994, net imports supplied 12 percent ( 2,462 billion cubic feet) of the total gas demand requirements.

The net imported gas volume was 6.7 billion cubic feet per day in 1994. Without imported gas, the surplus capacity would be reduced. The surplus capacity in 1994 was only 14 billion cubic feet per day. If demand continues to rise without an increase in gas-well completions, surplus capacity may not be able to cover the loss of imported gas. 


\section{Producing Areas}

This section of the report details the natural gas wellhead productive capacity by State or area where Dwight's gas-well gas production data are available. From these data, individual studies are made for each of six States: California, Kansas, Louisiana, New Mexico, Oklahoma, Texas, and the Gulf of Mexico Federal Offshore Outer Continental Shelf (OCS).

The remaining Dwight's data are combined into 3 groups of States (Figure 3). Five states are grouped together as Rocky Mountains: Colorado, Montana, North Dakota, Utah, and Wyoming. Three states are combined as the Southeast group, consisting of Alabama, Arkansas, and Mississippi. The third group is made up of 18 States: 3 States with Dwight's data-Michigan, Nebraska, and South Dakota and 15-Arizona, Florida, Illinois, Indiana, Kentucky, Maryland, Missouri, Nevada, New York, Ohio, Oregon, Pennsylvania, Tennessee, Virginia, and West Virginiafor which no Dwight's data are available.

Each State or group of States has its own unique, initially scheduled monthly gas production rate for January 1995 set to the same values for the low, base, and high cases. However, the actual production rate in an area will be less than its initially scheduled production rate if its scheduled production rate exceeds its gas productive capacity. Scheduled gas production is the production demand for the United States taken from the Energy Information Administration's Short-Term Integrated Forecasting System, Fourth Quarter 1996, $\{11\}$ and prorated among the States and areas.

For each State or area where the scheduled production exceeds the gas productive capacity, the deficit capacity (the negative difference between capacity and scheduled production) is rescheduled to States and areas with surplus capacity. The production for these deficit capacity States will be greater in the base and high cases because there will be more well completions. The larger number of well completions adds more capacity and reduces or eliminates the deficit capacity.

For States or areas where the scheduled production does not exceed capacity, the surplus capacity (the positive difference between capacity and scheduled production) is used to replace the deficit capacity of the States and areas with deficit capacities. For these surplus capacity States, the production rate will be highest in the low case because there is a larger deficit capacity to make up. 


\section{Gulf of Mexico OCS}

The Gulf of Mexico OCS is a prolific natural gas producer with large seasonal variations in producing rate. In 1994, more than a quarter of the lower 48 States' dry gas production came from this area. Mobile Block 823 producing $70 \mathrm{Bcf}$, was the largest OCS natural gas producer in 1994. Garden Banks 236 was the second largest producer making $69 \mathrm{Bcf}$, and Matagorda Island 623 , the third largest producer, producing $64 \mathrm{Bcf}$.

Surplus capacity was adequate from 1985 through 1995. Future projections show increases for the low, base, and high cases.

Figure 11 shows the dry gas production rate and wellhead productive capacity from 1985 through 1995, with projections through 1997. The January, June, and December historical production rates and capacities are presented in Table 3. Dry gas production and wellhead productive capacity projections are shown by Table 4 .

Figure 12 shows the number of gas-well completions added during each year from 1985 through 1995 and projected through 1997. There is an increase in the Gulf of Mexico completions for 1996 and a decrease in 1997. In 1996, the number of drilling rigs in the Gulf of
Mexico OCS increased. An increase in the number of completions resulted, because the number of completions is a function of the number of rigs. Lower- 48 rigs are forecast to increase in 1997 for the base and high cases and decrease for the low case. After taking into account the completion (per rig and area distribution factors the Gulf of Mexico OCS completions are expected to, increase in 1997 for the high case and decrease for the base and low cases. Current information indicates that several large platforms are scheduled to come on production during 1996.

The initial flow rate per well completion for the Gulf of Mexico is about eight million cubic feet per day (Appendix D). Most reservoirs in the Gulf of Mexico have high permeabilities and are water-drive reservoirs. This means that the reservoir can sustain a high flow rate throughout most of its producing life. However, the recovery efficiency is generally less than the recovery efficiency for reservoirs with other types of drive mechanisms. It is common for a Gulf of Mexico OCS gas-well completion to produce eight billion cubic feet of gas over its life.

Figure 11. Gulf of Mexico Ocs Dry Gas Monthly Production Rate and Wellhead Productive Capacity, 1985-1997

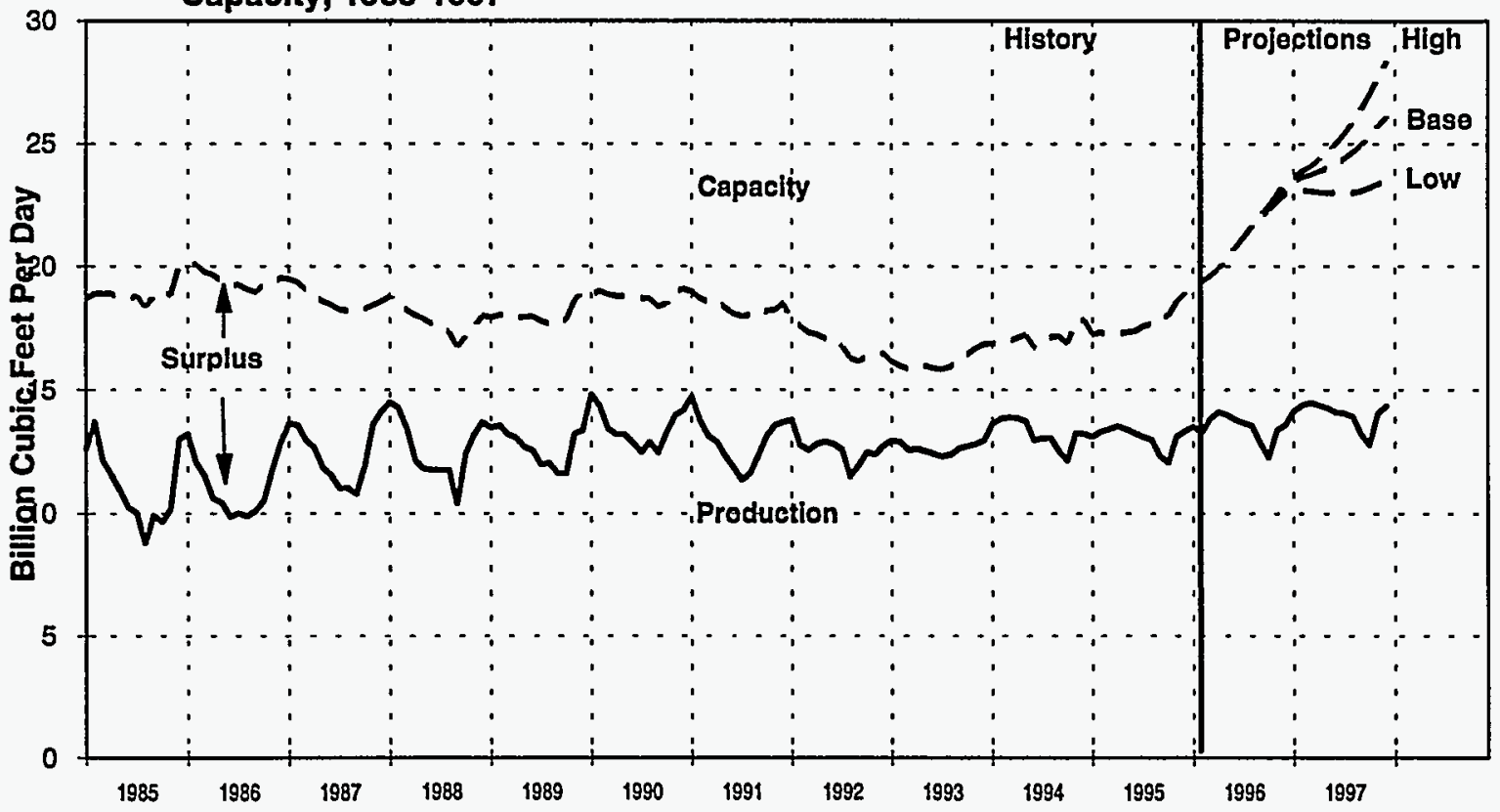

Note: Production projection plotted for base case only. The 1995 estimated history is based on Model GASCAP94 C110196 projections. Sources: Production History: Energy Information Adminlstration, Office of Oll and Gas; Dwight's Energydata, Inc.; and Model GASCAP94 C110196. Productive Capacity: Model GASCAP94 C110196. Production Projections: Energy Information Administration, Short-Term Integrated Forecasting System, Fourth Quarter 1996, and Model GASCAP94 C110196. 
Table 3. Gulf of Mexico OCS Dry Gas Production and Wellhead Productive Capacity, 1985-1995 (Million Cubic Feet Per Day)

\begin{tabular}{|c|c|c|c|c|c|c|}
\hline \multirow[b]{2}{*}{ Month-Year } & \multirow[b]{2}{*}{$\begin{array}{c}\text { Dry } \\
\text { Production }\end{array}$} & \multicolumn{5}{|c|}{ Dry Gas Productive Capacity } \\
\hline & & $\begin{array}{c}\text { Gas-Well } \\
\text { Gas }\end{array}$ & $\begin{array}{c}\text { Oil-Well } \\
\text { Gas }\end{array}$ & $\begin{array}{l}\text { Total } \\
\text { Gas }\end{array}$ & $\begin{array}{c}\text { Total } \\
\text { Surplus }\end{array}$ & $\begin{array}{l}\text { Utilization } \\
\text { (percent) }\end{array}$ \\
\hline Jan-85 & 12,591 & 17,317 & 1,373 & 18,690 & 6,099 & 67.4 \\
\hline Jun-85 & 10,261 & 17,123 & 1,539 & 18,662 & 8,401 & 55.0 \\
\hline Dec-85 & 12,969 & 18,493 & 1,530 & 20,023 & 7,054 & 64.8 \\
\hline Jan-86 & 13,177 & 18,461 & 1,585 & 20,046 & 6,869 & 65.7 \\
\hline Jun-86 & 9,891 & 17,752 & 1,460 & 19,212 & 9,321 & 51.5 \\
\hline Dec-86 & 12,823 & 18,038 & 1,489 & 19,527 & 6,704 & 65.7 \\
\hline Jan-87 & 13,620 & 18,066 & 1,416 & 19,482 & 5,862 & 69.9 \\
\hline Jun-87 & 11,532 & 17,127 & 1,317 & 18,444 & 6,912 & 62.5 \\
\hline Dec-87 & 14,124 & 17,329 & 1,252 & 18,581 & 4,457 & 76.0 \\
\hline Jan-88 & 14,490 & 17,526 & 1,254 & 18,780 & 4,290 & 77.2 \\
\hline Jun-88 & 11,750 & 16,385 & 1,309 & 17,694 & 5,944 & 66.4 \\
\hline Dec-88 & 13,659 & 16,681 & 1,314 & 17,995 & 4,336 & 75.9 \\
\hline Jan-89 & 13,439 & 16,644 & 1,286 & 17,930 & $4,491^{\circ}$ & 75.0 \\
\hline Jun-89 & 12,535 & 16,757 & 1,224 & 17,981 & 5,446 & 69.7 \\
\hline Dec-89 & 13,346 & 17,886 & 1,085 & 18,971 & 5,625 & 70.3 \\
\hline Jan-90 & 14,793 & 17,622 & 1,220 & 18,842 & 4,049 & 78.5 \\
\hline Jun-90 & 12,827 & 17,533 & 1,184 & 18,717 & 5,890 & 68.5 \\
\hline Dec-90 & 14,153 & 17,852 & 1,228 & 19,080 & 4,927 & 74.2 \\
\hline Jan-91 & 14,695 & 17,681 & 1,301 & 18,982 & 4,287 & 77.4 \\
\hline Jun-91 & 11,846 & 16,767 & 1,314 & 18,081 & 6,235 & 65.5 \\
\hline Dec-91 & 13,677 & 17,056 & 1,434 & 18,490 & 4,813 & 74.0 \\
\hline Jan-92 & 13,740 & 16,471 & 1,325 & 17,796 & 4,056 & 77.2 \\
\hline Jun-92 & 12,791 & 15,664 & 1,297 & 16,961 & 4,170 & 75.4 \\
\hline Dec-92 & 12,721 & 15,239 & 1,233 & 16,472 & 3,751 & 77.2 \\
\hline Jan-93 & 12,928 & 14,792 & 1,353 & 16,145 & 3,217 & 80.1 \\
\hline Jun-93 & 12,384 & 14,499 & 1,377 & 15,876 & 3,492 & 78.0 \\
\hline Dec-93 & 12,936 & 15,462 & 1,378 & 16,840 & 3,904 & 76.8 \\
\hline Jan-94 & 13,605 & 15,346 & 1,538 & 16,884 & 3,279 & 80.6 \\
\hline Jun-94 & 12,961 & 15,185 & 1,548 & 16,733 & 3,772 & 77.5 \\
\hline Dec-94 & 13,202 & 16,206 & 1,632 & 17,838 & 4,636 & 74.0 \\
\hline Jan-95" & 13,086 & 15,593 & 1,652 & 17,245 & 4,159 & 75.9 \\
\hline Jun-95' & 13,229 & 15,627 & 1,744 & 17,371 & 4,142 & 76.2 \\
\hline Dec-95" & 13,319 & 17,171 & 1,743 & 18,914 & 5,595 & 70.4 \\
\hline
\end{tabular}

\footnotetext{
"The 1995 estimated history is based on Model GASCAP94 C110196 projections and Baker Hughes rig counts.

Sources: Production History: Energy Information Administration, Office of Oil and Gas; Dwight's Energydata, Inc.; and Model GASCAP94 C11016. Productive Capacity: Model GASCAP94 C110196.
} 
Table 4. Gulf of Mexico OCS Dry Gas Production and Wellhead Productive Capacity Projections, 1996-1997 (Million Cubic Feet Per Day)

\begin{tabular}{|c|c|c|c|c|c|c|}
\hline \multirow[b]{2}{*}{ Month-Year } & \multirow[b]{2}{*}{$\begin{array}{c}\text { Dry } \\
\text { Production }\end{array}$} & \multicolumn{5}{|c|}{ Dry Gas Productive Capacity } \\
\hline & & $\begin{array}{c}\text { Gas-Well } \\
\text { Gas }\end{array}$ & $\begin{array}{c}\text { Oil-Well } \\
\text { Gas } \\
\end{array}$ & $\begin{array}{l}\text { Total } \\
\text { Gas } \\
\end{array}$ & $\begin{array}{c}\text { Total } \\
\text { Surplus }\end{array}$ & $\begin{array}{l}\text { Utilization } \\
\text { (percent) }\end{array}$ \\
\hline & \multicolumn{6}{|c|}{ Low Case Projection } \\
\hline Jan-96 & 13,496 & 17,395 & 1,766 & 19,161 & 5,665 & $\overline{70.4}$ \\
\hline Jun-96 & 13,783 & 18,993 & 1,776 & 20,769 & 6,986 & 66.4 \\
\hline Dec-96 & 13,587 & 21,140 & 1,821 & 22,961 & 9,374 & 59.2 \\
\hline Jan-97 & 14,141 & 21,214 & 1,819 & 23,033 & 8,892 & 61.4 \\
\hline Jun-97 & 14,076 & 21,154 & 1,844 & 22,998 & 8,922 & 61.2 \\
\hline \multirow[t]{2}{*}{ Dec-97 } & 14,567 & 21,611 & 1,846 & 23,457 & 8,890 & 62.1 \\
\hline & \multicolumn{6}{|c|}{ Base Case Projection } \\
\hline Jan-96 & 13,496 & 17,395 & 1,766 & 19,161 & 5,665 & $\overline{70.4}$ \\
\hline Jun-96 & 13,783 & 18,993 & 1,776 & 20,769 & 6,986 & 66.4 \\
\hline Dec-96 & 13,578 & 21,351 & 1,901 & 23,252 & 9,674 & 58.4 \\
\hline Jan-97 & 14,127 & 21,538 & 1,928 & 23,466 & 9,339 & 60.2 \\
\hline Jun-97 & 14,076 & 22,263 & 1,907 & 24,170 & 10,094 & 58.2 \\
\hline \multirow[t]{2}{*}{ Dec-97 } & 14,342 & 24,127 & 1,953 & 26,080 & 11,738 & 55.0 \\
\hline & \multicolumn{6}{|c|}{ High Case Projection } \\
\hline Jan-96 & 13,496 & 17,395 & 1,766 & 19,161 & 5,665 & 70.4 \\
\hline Jun-96 & 13,783 & 18,993 & 1,776 & 20,769 & 6,986 & 66.4 \\
\hline Dec-96 & 13,571 & 21,447 & 1,961 & 23,408 & 9,837 & 58.0 \\
\hline Jan-97 & 14,127 & 21,675 & 1,970 & 23,645 & 9,518 & 59.7 \\
\hline Jun-97 & 14,076 & 22,990 & 2,007 & 24,997 & 10,921 & 56.3 \\
\hline Dec-97 & 14,165 & 26,315 & 2,039 & 28,354 & 14,189 & 50.0 \\
\hline
\end{tabular}

Figure 13 shows the percent of the Gulf of Mexico OCS gas-well productive capacity in December of each year by age of the well. Gas-well completions that have been producing for less than one year contributed from 17 to 35 percent of the productive capacity from 1985 through 1995.

The gap between the capacity and production curves was continuing to narrow from 1985 through 1993. After 1993, new discoveries have reversed this trend. Several deep water projects are scheduled to commence production in 1996 and 1997. These projects, such as Shell's Ram Powell tension leg platform and their subsea Mensa project are reversing the declining surplus capacity trend for the OCS area.

The OCS area provides surplus capacity to meet major seasonal swings in the lower 48 States gas requirements. The future for this area to meet this role looks bright, especially if successful deep water projects continue to add adequate gas-well completions. 
Figure 12. Gulf of Mexico OCS Gas-Well Completions Added During Year, 1985-1997

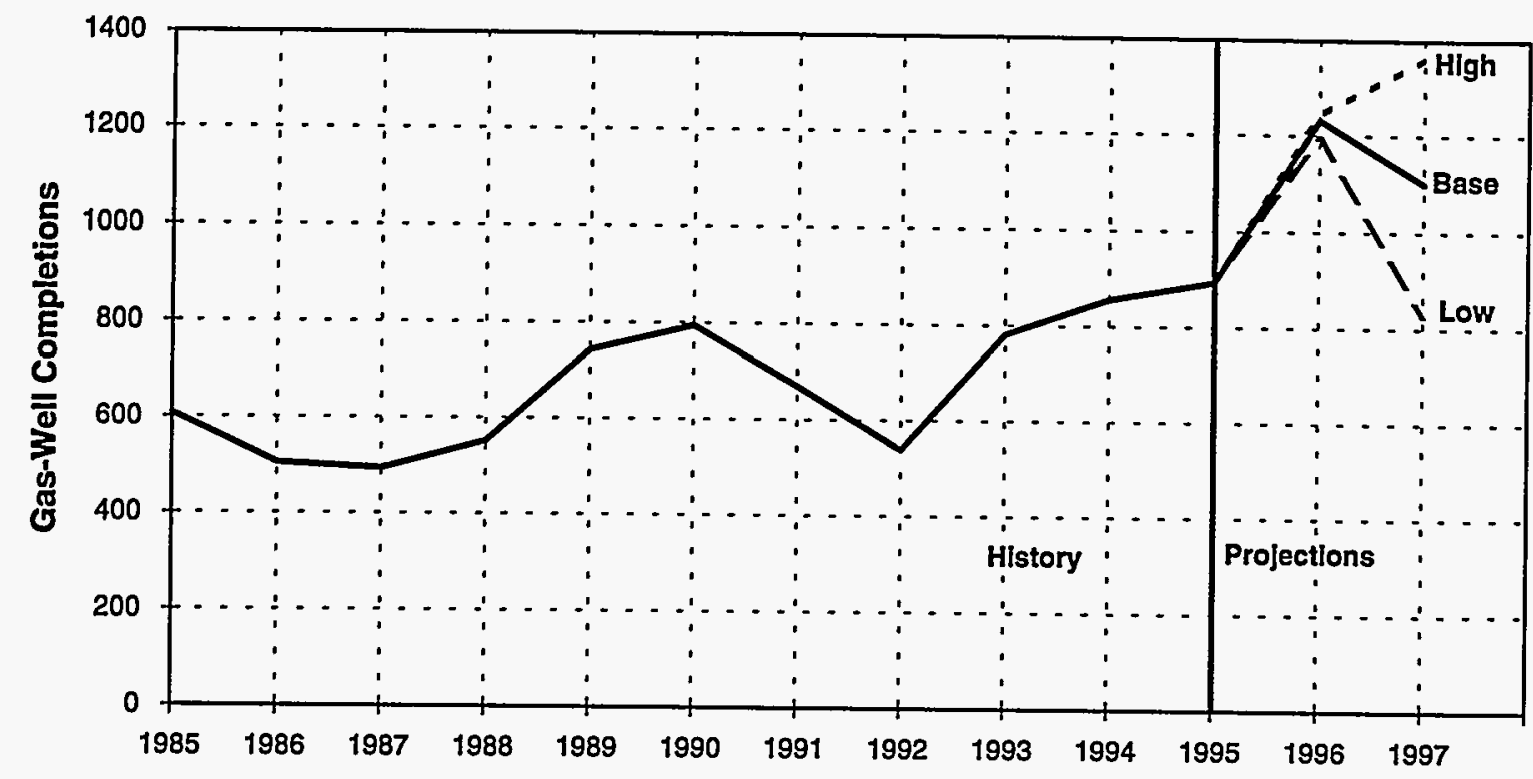

Note: The 1995 estlmated history is based on Drilling Rig Model projections and Baker Hughes rig counts. Completions Include recompletions in new producing zones.

Sources: History: Energy Information Administration, Office of Oil and Gas; Dwight's Energydata, Inc. Projections: Model GASCAP94 C110196.

Figure 13. Percent of Total Wellhead Productive Capacity of Gulf of Mexico Ocs Gas Wells by Well Age, 1985-1997 (Base Case)

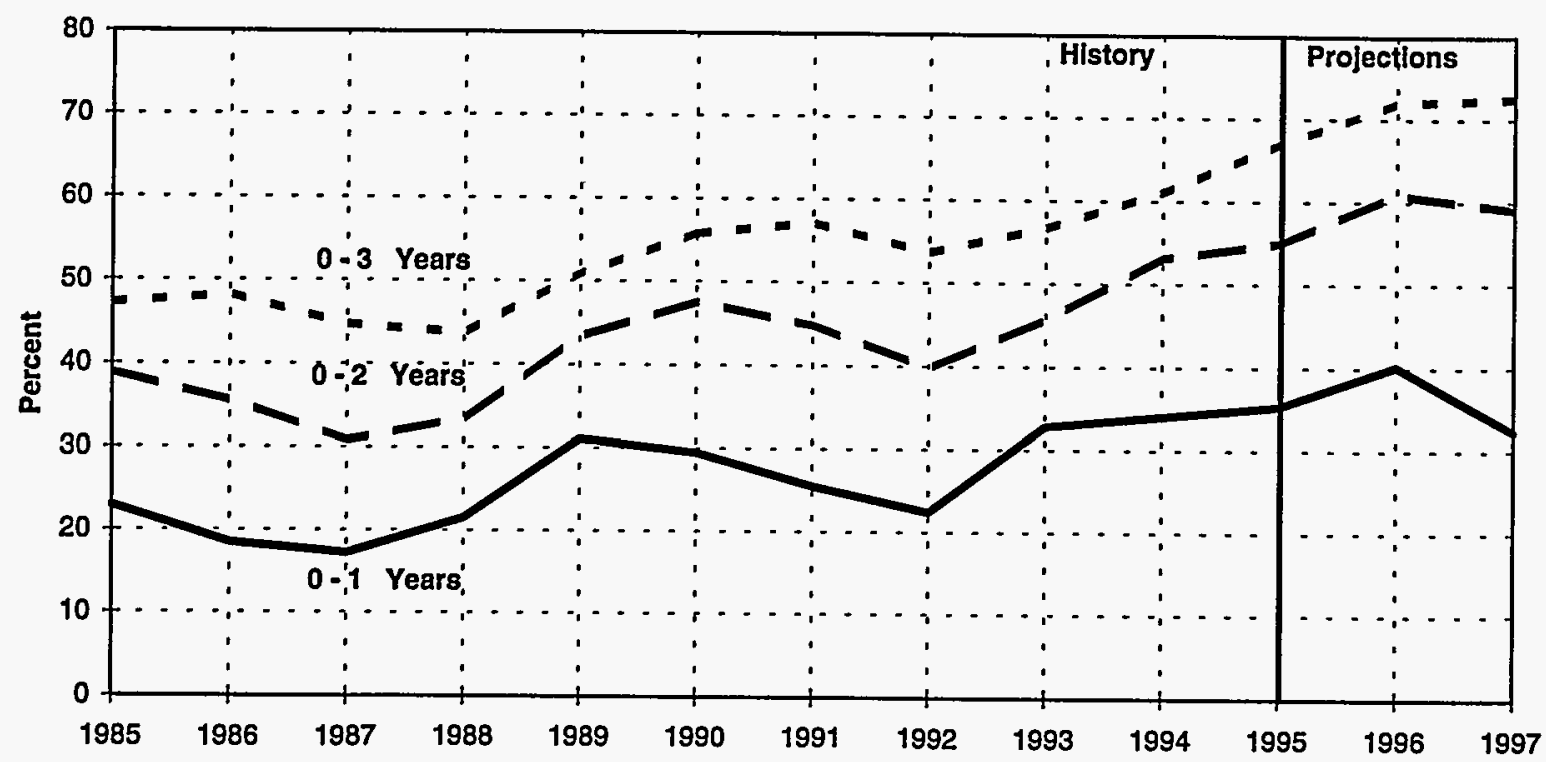

Sources: History: Energy Information Adminlstration, Office of Oil and Gas; Dwight's Energydata, Inc. Projections: Model SASCAP94 C110196. 


\section{Texas (Excluding Gulf of Mexico OCS)}

Texas gas production amounted to over a quarter of the lower 48 States dry gas production in 1994. Gas-producing zones range from high permeability, water-drive formations to low permeability "Tight Gas" reservoirs. The two largest gas-producing areas in 1994 in the State were the Carthage $(184 \mathrm{Bcf})$ and the Panhandle West (163 Bcf) fields.

Figure 14 shows the dry gas production rate and wellhead productive capacity from 1985 through 1994, with projections through 1997. The January, June, and December production rates and capacities are presented in Tables 5 and 6. Productive capacity began a very pronounced downturn beginning in 1986. After 1986, surplus capacity began to diminish (Figure 14). Consequently, capacity utilization increased from 1986 through 1995 (Table 5). The surplus capacity is projected to continue to increase in 1996 and 1997 for the base and high cases. Compared with the OCS, surplus capacities have not shown large increases in June. This reflects the fact that production requirements for Texas gas are less seasonal than for the Gulf of Mexico OCS.
Figure 15 shows the number of producing gas-well completions added during each year from 1985 through 1994, with projections through 1997. The number of gas-well completions declined sharply in 1986.

Initial flow rates for Texas wells range from high to relatively low. The average initial flow rate per well in Texas has been about one million cubic feet per day for the last few years (Table D1).

Figure 16 shows the percent of the Texas gas-well gas productive capacity for each year by age of well. Well completions that have been producing gas for less than one year contributed 25 percent of the gas-well gas productive capacity in 1995.

Figure 17 shows a comparison of the maximum daily rate monthly determined by the Texas Railroad Commission (TRC) and the gross gas-well gas productive capacity estimated in this study. The magnitude of the maximum daily rate as determined by TRC from the G-10 tests is higher than the productive capacity estimated in this report.

Figure 14. Texas (Excluding Gulf of Mexico OCS) Dry Gas Monthly Production Rate and Wellhead Productive Capacity, 1985-1997

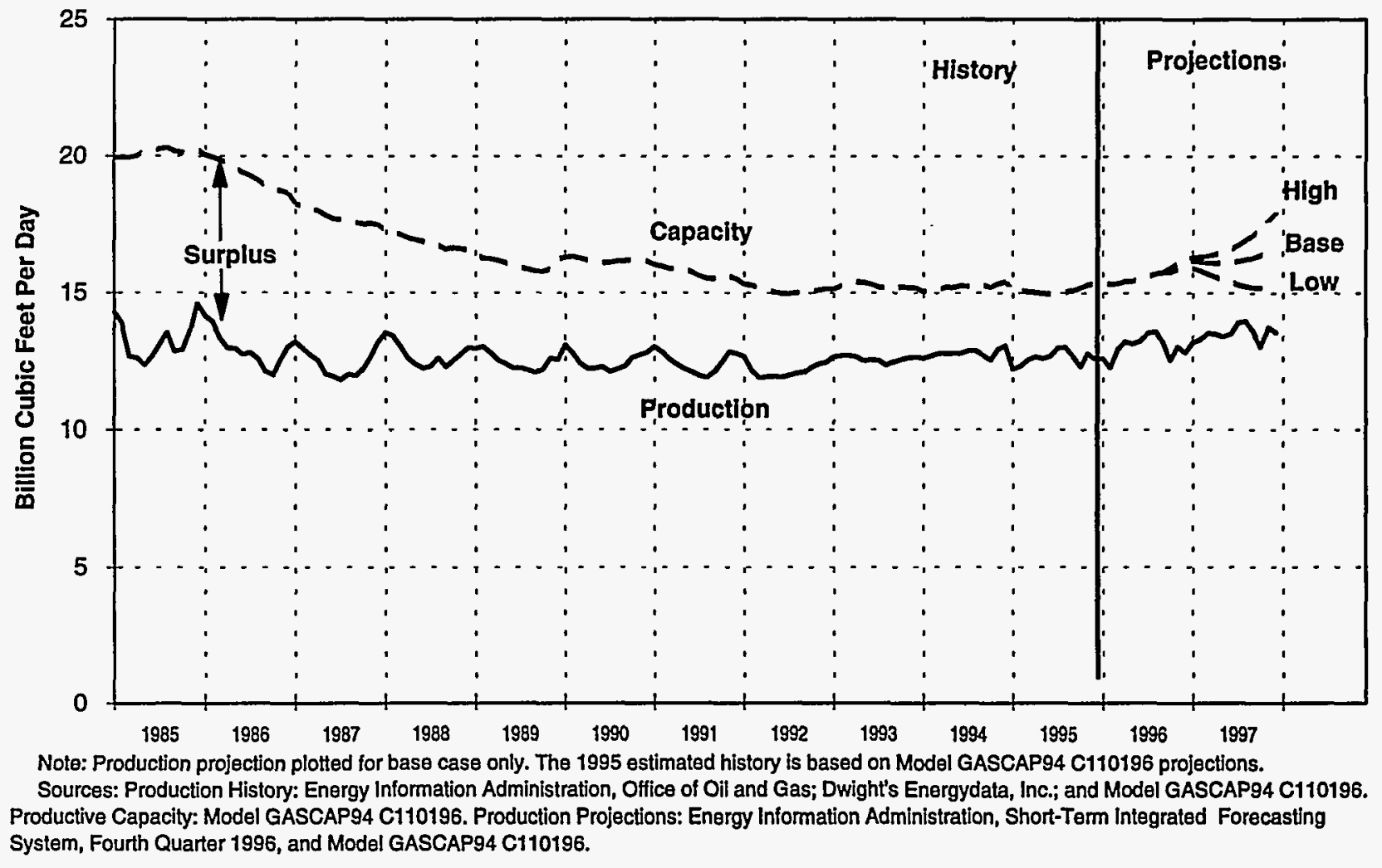


Table 5. Texas (Excluding Gulf of Mexico OCS) Dry Gas Production and Wellhead Productive Capacity, 1985-1995 (Million Cubic Feet Per Day)

\begin{tabular}{|c|c|c|c|c|c|c|}
\hline \multirow[b]{2}{*}{ Month-Year } & \multirow[b]{2}{*}{$\begin{array}{c}\text { Dry } \\
\text { Production }\end{array}$} & \multicolumn{5}{|c|}{ Dry Gas Productive Capacity } \\
\hline & & $\begin{array}{c}\text { Gas-Well } \\
\text { Gas } \\
\end{array}$ & $\begin{array}{c}\text { Oll-Well } \\
\text { Gas }\end{array}$ & $\begin{array}{l}\text { Total } \\
\text { Gas }\end{array}$ & $\begin{array}{c}\text { Total } \\
\text { Surplus } \\
\end{array}$ & $\begin{array}{l}\text { Utilization } \\
\text { (percent) }\end{array}$ \\
\hline Jan-85 & 14,287 & 16,531 & 3,398 & 19,929 & 5,642 & 71.7 \\
\hline Jun-85 & 12,657 & 16,757 & 3,398 & 20,155 & 7,498 & 62.8 \\
\hline Dec-85 & 14,589 & 16,816 & 3,421 & 20,237 & 5,648 & 72.1 \\
\hline Jan-86 & 14,148 & 16,546 & 3,509 & 20,055 & 5,907 & 70.5 \\
\hline Jun-86 & 12,749 & 16,134 & 3,267 & 19,401 & 6,652 & 65.7 \\
\hline Dec-86 & 13,007 & 15,517 & 3,146 & 18,663 & 5,656 & 69.7 \\
\hline Jan-87 & 13,217 & 15,117 & 3,140 & 18,257 & 5,040 & 72.4 \\
\hline Jun-87 & 11,918 & 14,672 & 3,033 & 17,705 & 5,787 & 67.3 \\
\hline Dec-87 & 13,196 & 14,474 & 3,025 & 17,499 & 4,303 & 75.4 \\
\hline Jan-88 & 13,542 & 14,126 & 3,150 & 17,276 & 3,734 & 78.4 \\
\hline Jun-88 & 12,233 & 13,792 & 3,074 & 16,866 & 4,633 & 72.5 \\
\hline Dec-88 & 13,001 & 13,561 & 2,993 & 16,554 & 3,553 & 78.5 \\
\hline Jan-89 & 12,969 & 13,333 & 3,080 & 16,413 & 3,444 & 79.0 \\
\hline Jun-89 & 12,247 & 13,017 & 2,954 & 15,971 & 3,724 & 76.7 \\
\hline Dec-89 & 12,564 & 13,397 & 2,833 & 16,230 & 3,666 & 77.4 \\
\hline Jan-90 & 13,095 & 13,340 & 2,963 & 16,303 & 3,208 & 80.3 \\
\hline Jun-90 & 12,292 & 13,206 & 2,888 & 16,094 & 3,802 & 76.4 \\
\hline Dec-90 & 12,836 & 13,171 & 2,982 & 16,153 & 3,317 & 79.5 \\
\hline Jan-91 & 13,040 & 13,080 & 2,951 & 16,031 & 2,991 & 81.3 \\
\hline Jun-91 & 12,105 & 12,919 & 2,839 & 15,758 & 3,653 & 76.8 \\
\hline Dec-91 & 12,778 & 12,702 & 2,809 & 15,511 & 2,733 & 82.4 \\
\hline Jan-92 & 12,668 & 12,399 & 2,926 & 15,325 & 2,657 & 82.7 \\
\hline Jun-92 & 11,913 & 12,153 & 2,826 & 14,979 & 3,066 & 79.5 \\
\hline Dec-92 & 12,476 & 12,340 & 2,811 & 15,151 & 2,675 & 82.3 \\
\hline Jan-93 & 12,676 & 12,112 & 3,038 & 15,150 & 2,474 & 83.7 \\
\hline Jun-93 & 12,562 & 12,370 & 2,945 & 15,315 & 2,753 & 82.0 \\
\hline Dec-93 & 12,658 & 12,281 & 2,900 & 15,181 & 2,523 & 83.4 \\
\hline Jan-94 & 12,630 & 12,195 & 2,851 & 15,046 & 2,416 & 83.9 \\
\hline Jun-94 & 12,797 & 12,508 & 2,751 & 15,259 & 2,462 & 83.9 \\
\hline Dec-94 & 13,069 & 12,693 & 2,712 & 15,405 & 2,336 & 84.8 \\
\hline Jan-95: & 12,208 & 12,392 & 2,684 & 15,076 & 2,868 & 81.0 \\
\hline Jun-95' & 12,698 & 12,371 & 2,588 & 14,959 & 2,261 & 84.9 \\
\hline Dec-95" & 12,587 & 12,812 & 2,537 & 15,349 & 2,762 & 82.0 \\
\hline
\end{tabular}

"The 1995 estimated history is based on Model GASCAP94 C110196 projections and Baker Hughes rig counts.

Sources: Production History: Energy Information Administration, Office of Oil and Gas; Dwight's Energydata, Inc.; and Model GASCAP94 C11016. Productive Capacity: Model GASCAP94 C110196. 
Table 6. Texas (Excluding Gulf of Mexico OCS) Dry Gas Production and Wellhead Productive Capacity Projections, 1996-1997 (Million Cubic Feet Per Day)

\begin{tabular}{|c|c|c|c|c|c|c|}
\hline \multirow[b]{2}{*}{ Month-Year } & \multirow[b]{2}{*}{$\begin{array}{c}\text { Dry } \\
\text { Production }\end{array}$} & \multicolumn{5}{|c|}{ Dry Gas Productive Capacity } \\
\hline & & $\begin{array}{c}\text { Gas-Well } \\
\text { Gas }\end{array}$ & $\begin{array}{c}\text { Oil-Well } \\
\text { Gas }\end{array}$ & $\begin{array}{c}\text { Total } \\
\text { Gas }\end{array}$ & $\begin{array}{c}\text { Total } \\
\text { Surplus } \\
\end{array}$ & $\begin{array}{l}\text { Utilization } \\
\text { (percent) }\end{array}$ \\
\hline & \multicolumn{6}{|c|}{ Low Case Projection } \\
\hline Jan-96 & 12,611 & 12,794 & 2,563 & 15,357 & 2,746 & 82.1 \\
\hline Jun-96 & 13,254 & 12,954 & 2,568 & 15,522 & 2,268 & 85.4 \\
\hline Dec-96 & 12,847 & 13,494 & 2,472 & 15,966 & 3,119 & 80.5 \\
\hline Jan-97 & 13,216 & 13,471 & 2,442 & 15,913 & 2,697 & 83.1 \\
\hline Jun-97 & 13,504 & 13,060 & 2,372 & 15,432 & 1,928 & 87.5 \\
\hline \multirow[t]{2}{*}{ Dec-97 } & 13,777 & 12,895 & 2,288 & 15,183 & 1,406 & 90.7 \\
\hline & \multicolumn{6}{|c|}{ Base Case Projection } \\
\hline Jan-96 & 12,611 & 12,794 & 2,563 & 15,357 & 2,746 & 82.1 \\
\hline Jun-96 & 13,254 & 12,954 & 2,568 & 15,522 & 2,268 & 85.4 \\
\hline Dec-96 & 12,838 & 13,603 & 2,521 & 16,124 & 3,286 & 79.6 \\
\hline Jan-97 & 13,203 & 13,637 & 2,510 & 16,147 & 2,944 & 81.8 \\
\hline Jun-97 & 13,504 & 13,645 & 2,468 & 16,113 & 2,609 & 83.8 \\
\hline \multirow[t]{2}{*}{ Dec-97 } & 13,565 & 14,220 & 2,429 & 16,649 & 3,084 & 81.5 \\
\hline & \multicolumn{6}{|c|}{ High Case Projection } \\
\hline Jan-96 & 12,611 & 12,794 & 2,563 & 15,357 & 2,746 & 82.1 \\
\hline Jun-96 & 13,254 & 12,954 & 2,568 & 15,522 & 2,268 & 85.4 \\
\hline Dec-96 & 12,831 & 13,659 & 2,563 & 16,222 & 3,391 & 79.1 \\
\hline Jan-97 & 13,203 & 13,714 & 2,575 & 16,289 & 3,086 & 81.1 \\
\hline Jun-97 & 13,504 & 14,046 & 2,548 & 16,594 & 3,090 & 81.4 \\
\hline Dec-97 & 13,397 & 15,402 & 2,535 & 17,937 & 4,540 & 74.7 \\
\hline
\end{tabular}

Sources: Production Projections: Energy Information Administration, Short-Term Integrated Forecasting System, and Model GASCAP94 C110196. Productive Capacity Projections: Model GASCAP94 C110196. 
Figure 15. Texas (Excluding Gulf of Mexico OCS) Gas-Well Completions Added During Year, 1985-1997

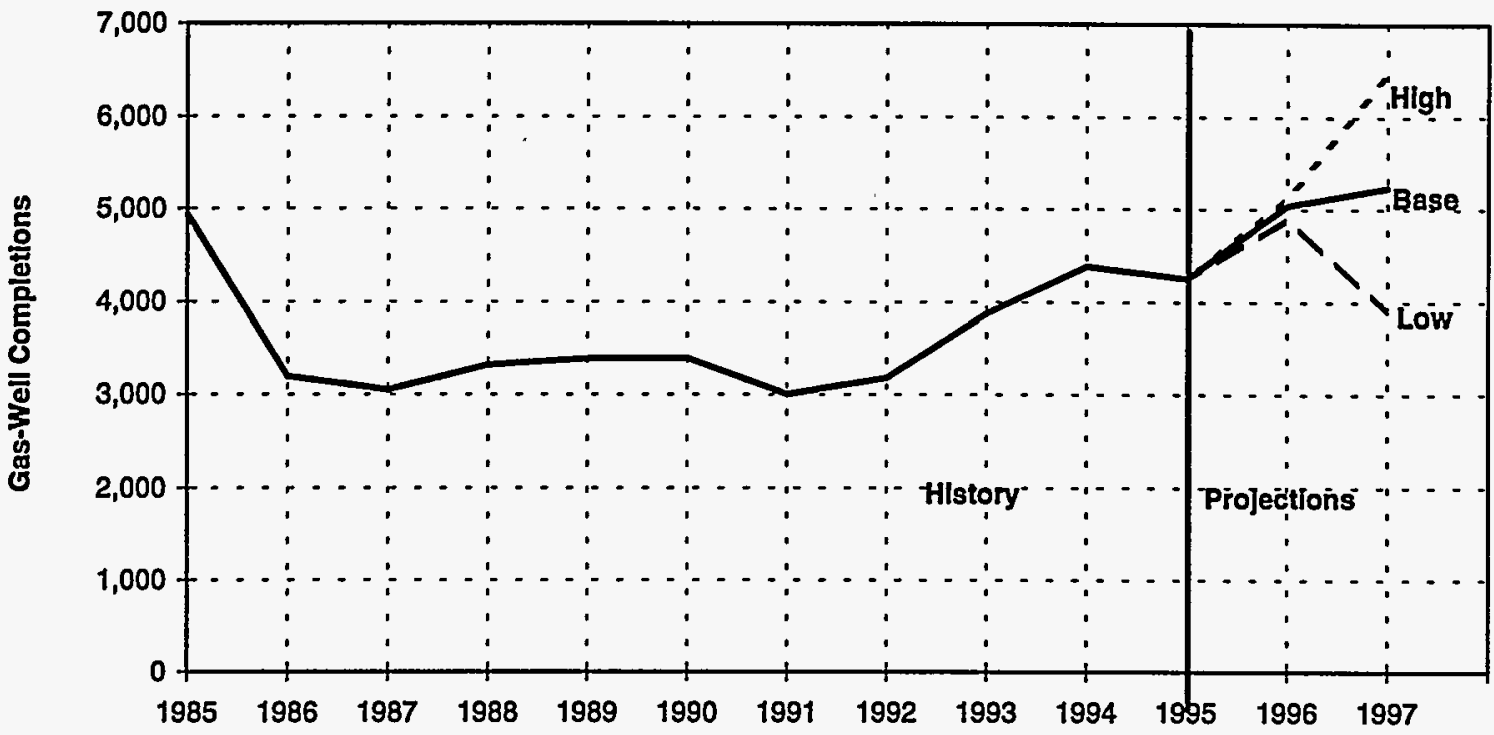

Note: The 1995 estimated history is based on Drilling Rig Model projections and Baker Hughes rig counts. Completions include recompletions in new producing zones.

Sources: History: Energy Information Administration, Office of Oll and Gas; Dwight's Energydata, Inc. Projections: Model GASCAP94 C110196.

Figure 16. Percent of Total Wellhead Productive Capacity of Texas (Excluding Gulf of Mexico OCS) Gas Wells by Well Age, 1985-1997 (Base Case)

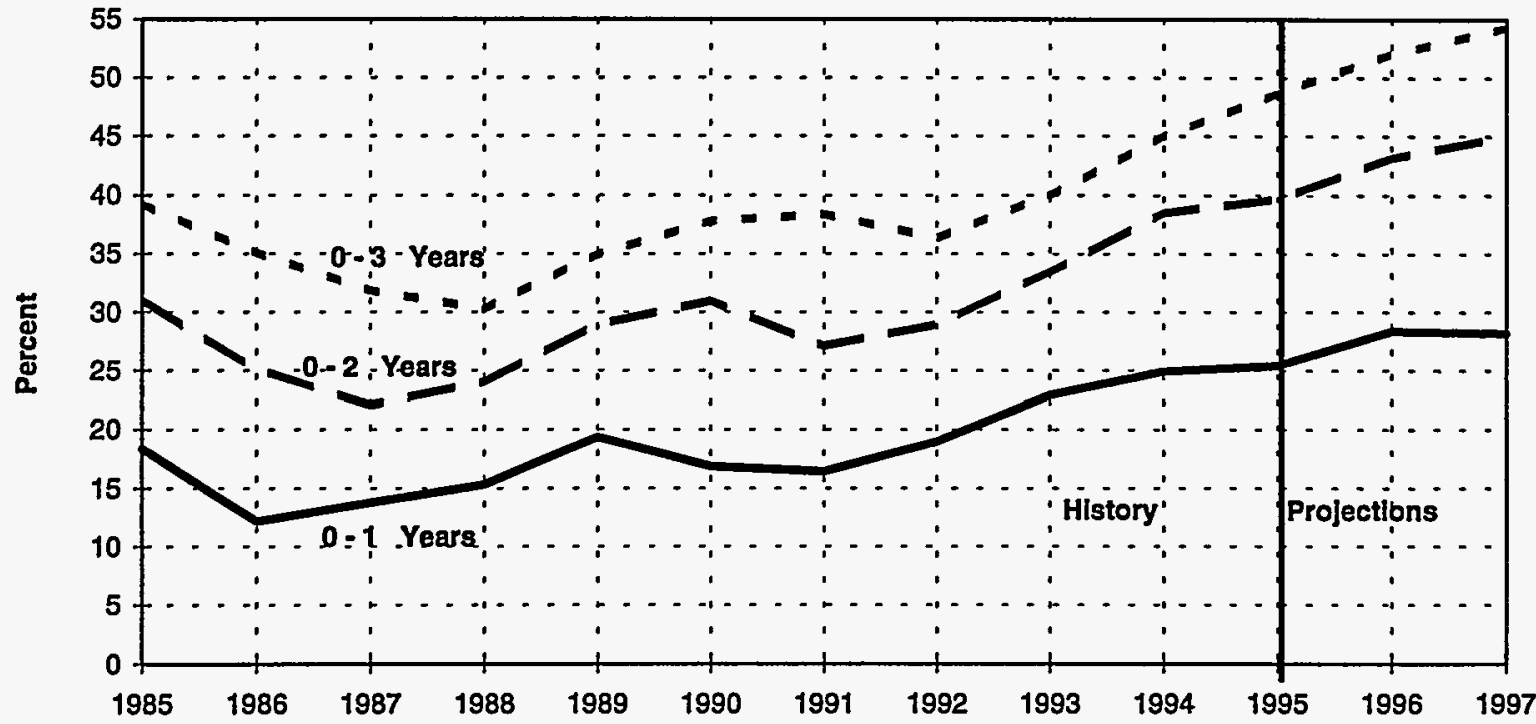

Sources: History: Energy Information Administration, Office of Oil and Gas; Dwight's Energydata, Inc. Projections: Model GASCAP94 C110196. 


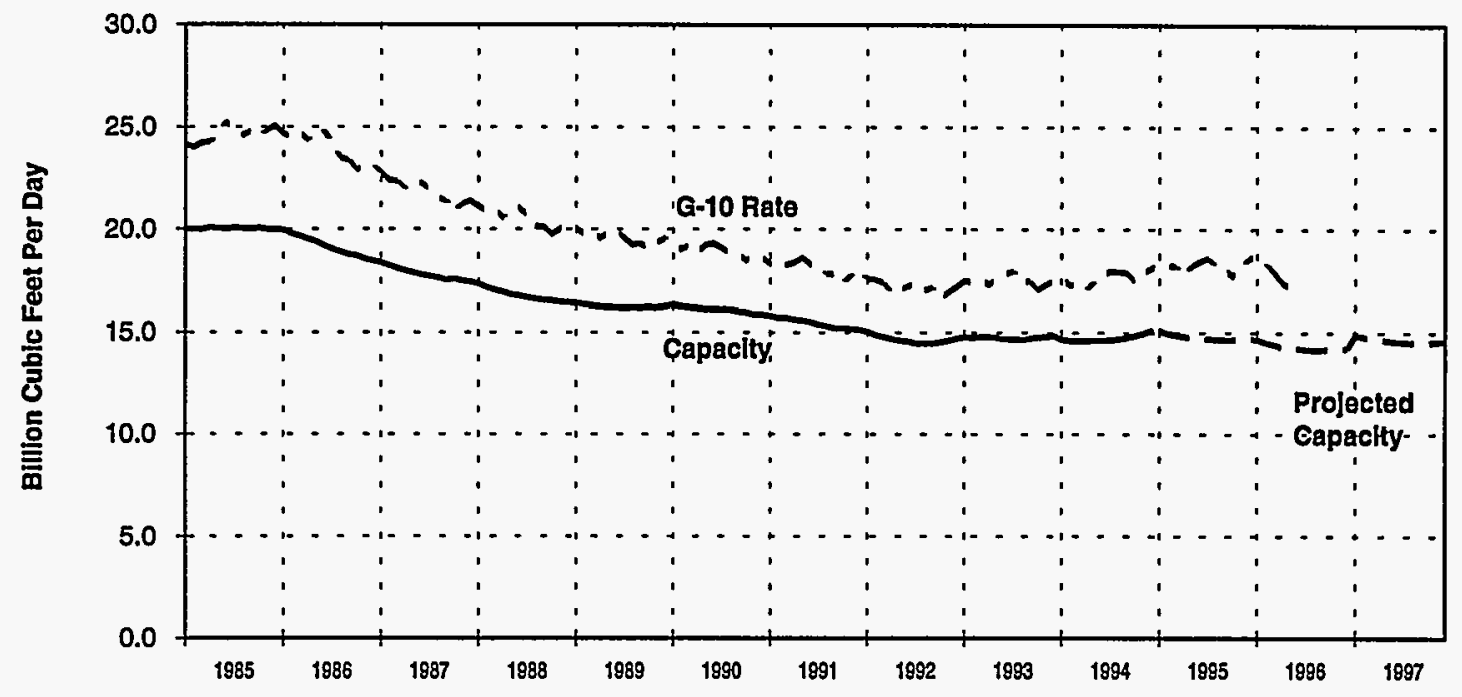

Note: Capacity projectlon plotted for base case only.

Sources: History: Energy Information Administration, Office of Oil and Gas; Dwight's Energydata, Inc.; and Railroad Commission of Texas. Projections: Model GASCAP94 C110196.

Operators of Texas gas wells are required to make a production test of each gas well semi-annually and report the test on Form G-10 unless the well is exempt from testing. All gas wells producing less than 100 thousand cubic feet per day are automatically exempt. Each month, the TRC determines statewide gas well deliverability by summing the latest available G-10 test rates. However, the TRC does not necessarily expect that this deliverability (sum of G-10 test rates) can be achieved. This is true for the following reasons:

- The daily rate reported on a Form G-10 is of 72 hours duration, and that rate cannot be sustained for a month by most gas-well completions.

- If all gas-well completions were produced at the daily rate shown on a G-10, increased back-pressures would result, prohibiting gas from many wells from getting into the pipeline system.

- The daily rates reported on the form G-10 reflects the ability of gas-well completions to produce at the time they are tested. However, each TRC deliverability estimate (sum of latest G-10 tests) contains well test data that may be as much as five or more months old.

Capacity estimated in this report is the daily rate that can be sustained for a month. Rates reported on the G-10 tests are required to be sustainable for only 72 hours.

Both, however, exhibit a similar downward trend. Capacity is projected to increase during 1996 and 1997. Data from the G-10 tests are plotted through June 1996. 


\section{Louisiana (Excluding Gulf of Mexico OCS)}

Louisiana has been a large producer of natural gas for many years. Gas produced comes from high permeability, water-drive, deep and sometimes over-pressured formations on the Gulf Coast as well as from low permeability and relatively shallow reservoirs in North Louisiana. In 1994, the two fields producing the largest volume of natural gas in the State were the Chalkey (63 Bcf) and Lake Arthur South (63 Bcf) fields, according to Dwight's data. In 1994, almost 9 percent of the total dry gas produced in the lower 48 States came from Louisiana. $\{13\}$
The following pages include Tables 7 and 8 and Figures 18 through 20, which provide historical and projected production and productive capacity, gas-well completions added, and percent of capacity by well age. These data exclude the OCS.

Production and productive capacity are equal with no surplus in November and December of 1995, 1996, and 1997 for all three cases. For the low case, there is no surplus for the two additional months of September and October of 1997. The production is plotted for the base case only in Figure 18.

Figure 18. Louisiana (Excluding Gulf of Mexico OCS) Dry Gas Monthly Production Rate and Wellhead Productive Capacity, 1985-1997

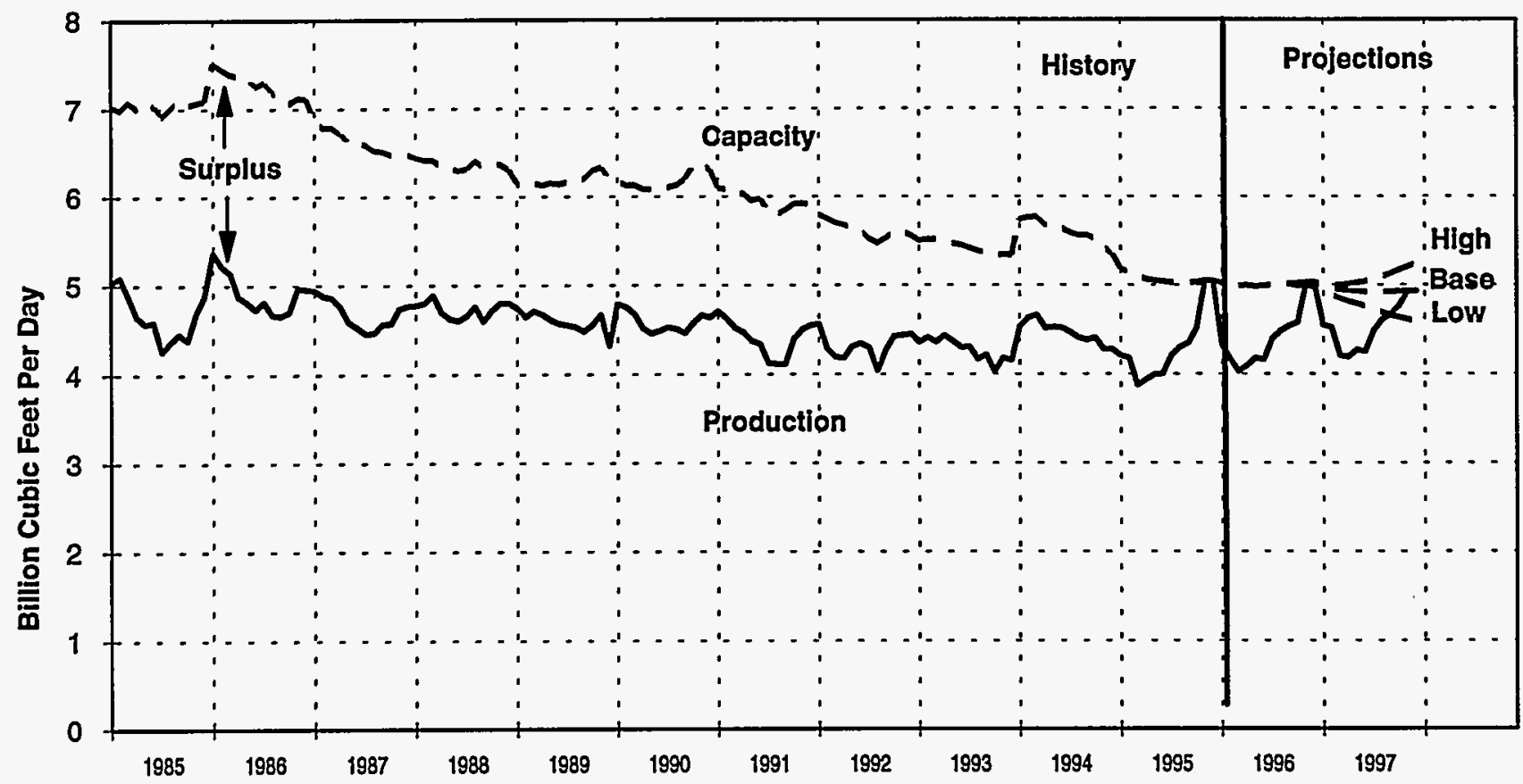

Note: Productlon projection plotted for base case only. The 1995 estimated history is based on Model GASCAP94 C110196 projections.

Sources: Production HIstory: Energy Information Administration, Office of Oil and Gas; Dwight's Energydata, Inc.; and Model GASCAP94 C110196. Productive Capacity: Model GASCAP94 C110196. Production Projections: Energy Information Administration, Short-Term Integrated Forecasting System, Fourth Quarter 1996, and Model GASCAP94 C110196. 
Table 7. Louisiana (Excluding Gulf of Mexico OCS) Dry Gas Production and Wellhead Productive Capacity, 1985-1995 (Million Cubic Feet Per Day)

\begin{tabular}{|c|c|c|c|c|c|c|}
\hline \multirow[b]{2}{*}{ Month-Year } & \multirow[b]{2}{*}{$\begin{array}{c}\text { Dry } \\
\text { Production }\end{array}$} & \multicolumn{5}{|c|}{ Dry Gas Productive Capacity } \\
\hline & & $\begin{array}{c}\text { Gas-Well } \\
\text { Gas } \\
\end{array}$ & $\begin{array}{c}\text { Oil-Well } \\
\text { Gas }\end{array}$ & $\begin{array}{l}\text { Total } \\
\text { Gas }\end{array}$ & $\begin{array}{c}\text { Total } \\
\text { Surplus }\end{array}$ & $\begin{array}{l}\text { Utilization } \\
\text { (percent) }\end{array}$ \\
\hline Jan-85 & 5,030 & 6,497 & 525 & 7,022 & 1,992 & 71.6 \\
\hline Jun-85 & 4,581 & 6,499 & 539 & 7,038 & 2,457 & 65.1 \\
\hline Dec-85 & 4,876 & 6,574 & 516 & 7,090 & 2,214 & 68.8 \\
\hline Jan-86 & 5,353 & 6,930 & 585 & 7,515 & 2,162 & 71.2 \\
\hline Jun-86 & 4,724 & 6,715 & 538 & 7,253 & 2,529 & 65.1 \\
\hline Dec-86 & 4,950 & 6,534 & 579 & 7,113 & 2,163 & 69.6 \\
\hline Jan-87 & 4,940 & 6,288 & 583 & 6,871 & 1,931 & 71.9 \\
\hline Jun-87 & 4,523 & 6,040 & 570 & 6,610 & 2,087 & 68.4 \\
\hline Dec-87 & 4,764 & 5,899 & 573 & 6,472 & 1,708 & 73.6 \\
\hline Jan-88 & 4,772 & 5,863 & 569 & 6,432 & 1,660 & 74.2 \\
\hline Jun-88 & 4,599 & 5,745 & 546 & 6,291 & 1,692 & 73.1 \\
\hline Dec-88 & 4,796 & 5,759 & 540 & 6,299 & 1,503 & 76.1 \\
\hline Jan-89 & 4,740 & 5,640 & 502 & 6,142 & 1,402 & 77.2 \\
\hline Jun-89 & 4,567 & 5,654 & 483 & 6,137 & 1,570 & 74.4 \\
\hline Dec-89 & 4,320 & 5,772 & 420 & 6,192 & 1,872 & 69.8 \\
\hline Jan-90 & 4,785 & 5,734 & 440 & 6,174 & 1,389 & 77.5 \\
\hline Jun-90 & 4,486 & 5,644 & 432 & 6,076 & 1,590 & 73.8 \\
\hline Dec-90 & 4,635 & 5,855 & 443 & 6,298 & 1,663 & 73.6 \\
\hline Jan-91 & 4,703 & 5,673 & 419 & 6,092 & 1,389 & 77.2 \\
\hline Jun-91 & 4,332 & 5,557 & 415 & 5,972 & 1,640 & 72.5 \\
\hline Dec-91 & 4,544 & 5,494 & 422 & 5,916 & 1,372 & 76.8 \\
\hline Jan-92 & 4,560 & 5,278 & 512 & 5,790 & 1,230 & 78.8 \\
\hline Jun-92 & 4,342 & 5,102 & 504 & 5,606 & 1,264 & 77.5 \\
\hline Dec-92 & 4,447 & 5,054 & 497 & 5,551 & 1,104 & 80.1 \\
\hline Jan-93 & 4,360 & 5,100 & 398 & 5,498 & 1,138 & 79.3 \\
\hline Jun-93 & 4,303 & 5,041 & 402 & 5,443 & 1,140 & 79.1 \\
\hline Dec-93 & 4,155 & 4,952 & 376 & 5,328 & 1,173 & 78.0 \\
\hline Jan-94 & 4,528 & 5,253 & 479 & 5,732 & 1,204 & 79.0 \\
\hline Jun-94 & 4,518 & 5,163 & 470 & 5,633 & 1,115 & 80.2 \\
\hline Dec-94 & 4,276 & 4,870 & 473 & 5,343 & 1,067 & 80.0 \\
\hline Jan- $95^{*}$ & 4,206 & 4,712 & 463 & 5,175 & 969 & 81.3 \\
\hline Jun-95 & 3,998 & 4,585 & 453 & 5,038 & 1,040 & 79.4 \\
\hline Dec-95" & 5,042 & 4,568 & 474 & 5,042 & 0 & 100.0 \\
\hline
\end{tabular}

The 1995 estimated history is based on Model GASCAP94 C110196 projections and Baker Hughes rig counts.

Sources: Production History: Energy Information Administration, Office of Oll and Gas; Dwight's Energydata, Inc.; and Model GASCAP94 C11016. Productive Capacity: Model GASCAP94 C110196. 
Table 8. Louisiana (Excluding Gulf of Mexico OCS) Dry Gas Production and Wellhead Productive Capacity Projections, 1996-1997 (Million Cubic Feet Per Day)

\begin{tabular}{|c|c|c|c|c|c|c|}
\hline \multirow[b]{2}{*}{ Month-Year } & \multirow[b]{2}{*}{$\begin{array}{c}\text { Dry } \\
\text { Production }\end{array}$} & \multicolumn{5}{|c|}{ Dry Gas Productive Capacity } \\
\hline & & $\begin{array}{c}\text { Gas-Well } \\
\text { Gas }\end{array}$ & $\begin{array}{c}\text { Oil-Well } \\
\text { Gas }\end{array}$ & $\begin{array}{l}\text { Total } \\
\text { Gas }\end{array}$ & $\begin{array}{c}\text { Total } \\
\text { Surplus } \\
\end{array}$ & $\begin{array}{l}\text { Utilization } \\
\text { (percent) }\end{array}$ \\
\hline & \multicolumn{6}{|c|}{ Low Case Projection } \\
\hline Jan-96 & 4,329 & 4,541 & 479 & 5,020 & 691 & 86.2 \\
\hline Jun-96 & 4,156 & 4,503 & 483 & 4,986 & 830 & 83.4 \\
\hline Dec-96 & 4,968 & 4,500 & 468 & 4,968 & 0 & 100.0 \\
\hline Jan-97 & 4,549 & 4,459 & 462 & 4,921 & 372 & 92.4 \\
\hline Jun-97 & 4,251 & 4,303 & 451 & 4,754 & 503 & 89.4 \\
\hline \multirow[t]{2}{*}{ Dec-97 } & 4,588 & 4,150 & 438 & 4,588 & 0 & 100.0 \\
\hline & \multicolumn{6}{|c|}{ Base Case Projection } \\
\hline Jan-96 & 4,329 & 4,541 & 479 & 5,020 & 691 & 86.2 \\
\hline Jun-96 & 4,156 & 4,503 & 483 & 4,986 & 830 & 83.4 \\
\hline Dec-96 & 5,002 & 4,525 & 477 & 5,002 & 0 & 100.0 \\
\hline Jan-97 & 4,544 & 4,498 & 475 & 4,973 & 429 & 91.4 \\
\hline Jun-97 & 4,251 & 4,449 & 470 & 4,919 & 668 & 86.4 \\
\hline \multirow[t]{2}{*}{ Dec-97 } & 4,929 & 4,464 & 465 & 4,929 & 0 & 100.0 \\
\hline & \multicolumn{6}{|c|}{ High Case Projection } \\
\hline Jan-96 & 4,329 & 4,541 & 479 & 5,020 & 691 & 86.2 \\
\hline Jun-96 & 4,156 & 4,503 & 483 & 4,986 & 830 & 83.4 \\
\hline Dec-96 & 5,025 & 4,540 & 485 & 5,025 & 0 & 100.0 \\
\hline Jan-97 & 4,544 & 4,518 & 487 & 5,005 & 461 & 90.8 \\
\hline Jun-97 & 4,251 & 4,551 & 485 & 5,036 & 785 & 84.4 \\
\hline Dec-97 & 5,232 & 4,746 & 486 & 5,232 & 0 & 100.0 \\
\hline
\end{tabular}

Sources: Production Projections: Energy Information Administration, Short-Term Integrated Forecasting System, Fourth Quarter 1996, and Model GASCAP94 C1 10196. Productive Capacity Projections: Model GASCAP94 C110196. 
Figure 19. Louisiana (Excluding Gulf of Mexico OCS) Gas-Well Completions Added During Year, 1985-1997

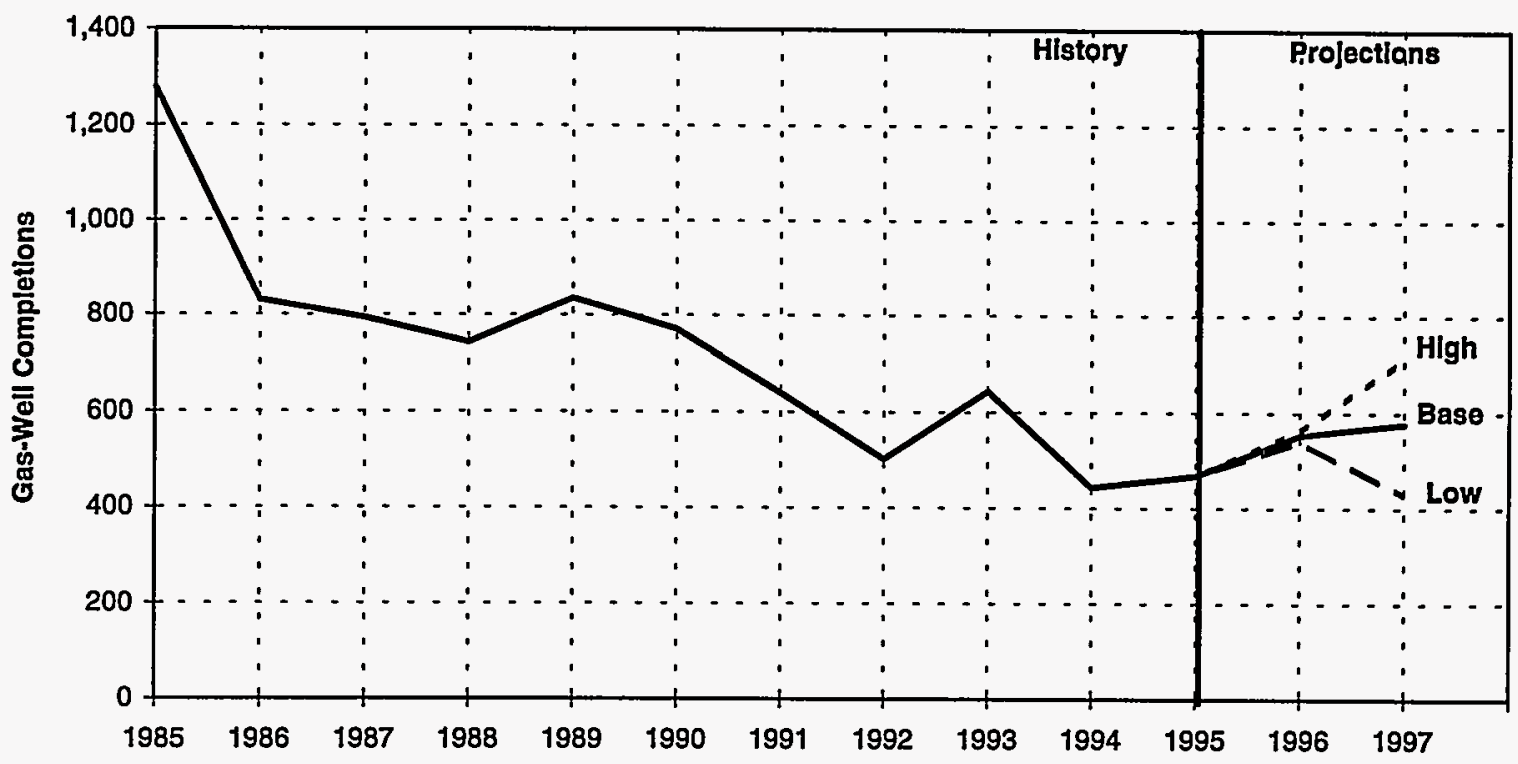

Note: The 1995 estimated history is based on Drilling Rig Model projections and Baker Hughes rig counts. Completions include recompletions in new producing zones.

Sources: History: Energy Information Administration, Office of Oll and Gas; Dwight's Energydata, Inc. Projections: Model GASCAP94 C110196.

Figure 20. Percent of Total Wellhead Productive Capacity of Louisiana (Excluding Gulf Mexico OCS) Gas Wells by Well Age, 1985-1997 (Base Case)

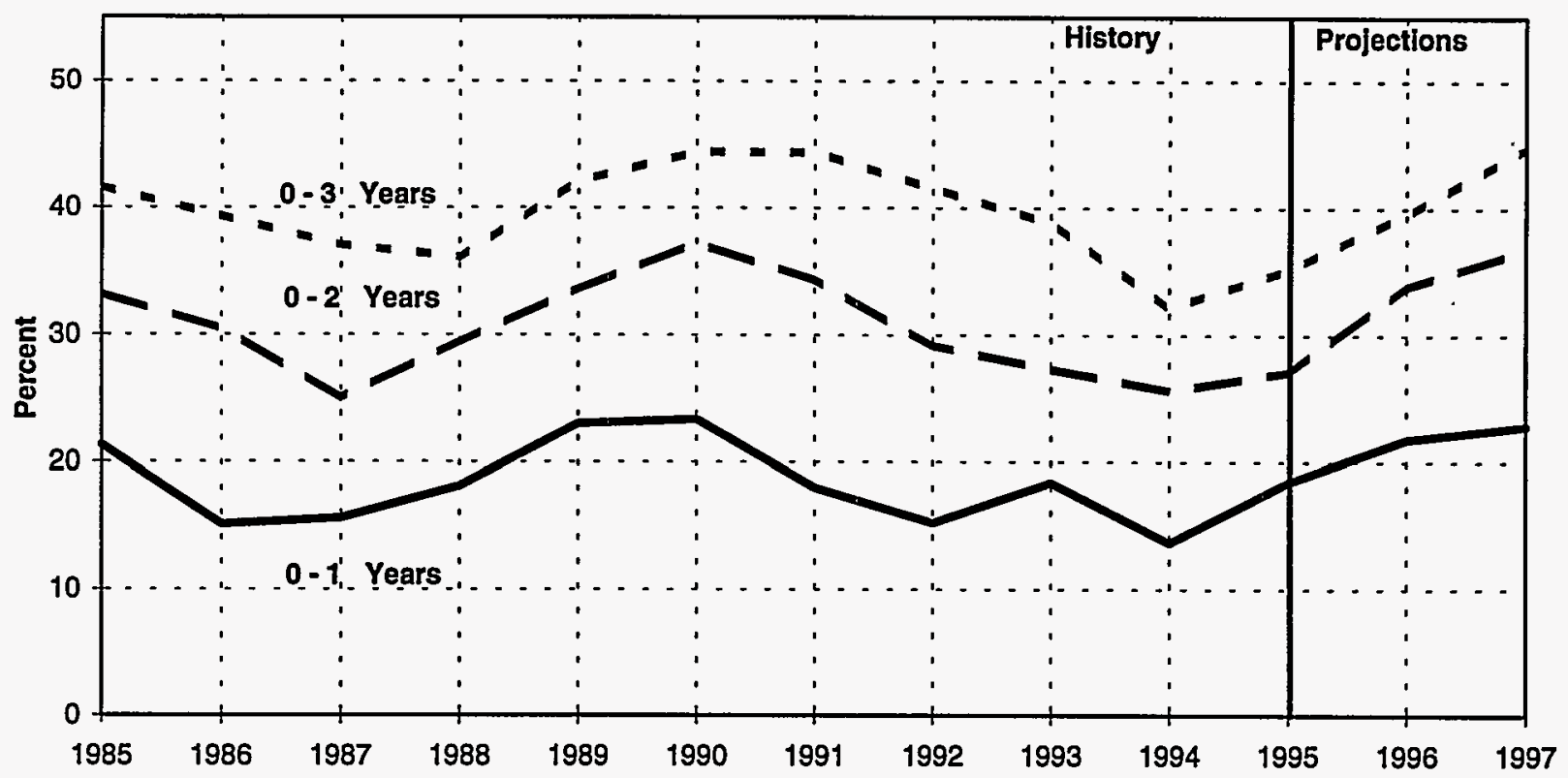

Sources: History: Energy Information Administration, Office of Oil and Gas; Dwight's Energydata, Inc. Projections: Model GASCAP94 C110196. 


\section{California (Including Pacific OCS)}

California is a net importer of natural gas. All California gas produced is used within the State. In 1994, more than half the total gas produced in California and Pacific OCS was oil-well gas. $\{13\}$

In 1994, Elk Hills and Coalingas East Extension oil fields were the two largest producers of natural gas. The two largest gas fields were Rio Vista and Pitas Point; the latter is in the Pacific OCS. This information was obtained from the California Department of Conservation.
The following pages include Tables 9 and 10 and Figures 21 through 23 , which provide historical and projected production and productive capacity, gas-well completions added, and percent of capacity by well age. These data include the OCS. Production and productive capacity are equal, with no surplus for November and December 1997 in the low case and for December 1997 in the base case.

Figure 21. California (Including Pacific OCS) Dry Gas Monthly Production Rate and Wellhead Productive Capacity, 1985-1997

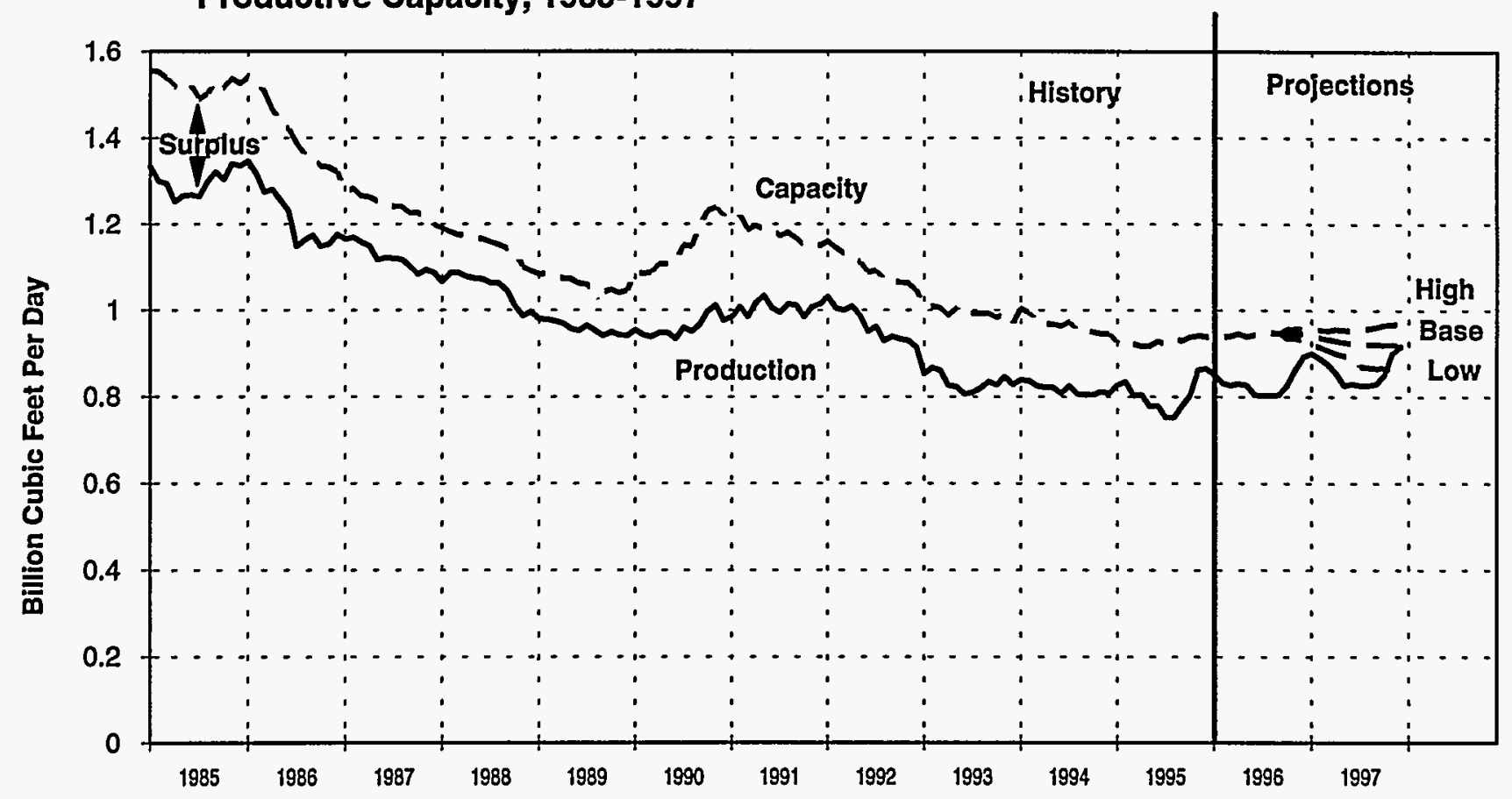

Note: Production projection plotted for base case only. The 1995 estimated history is based on Model GASCAP94 C110196 projections. Sources: Production History: Energy Information Administration, Office of Oil and Gas; Dwight's Energydata, Inc.; and Model GASCAP94 C110196. Productive Capacity: Model GASCAP94 C110196. Production Projections: Energy Information Administration, Short-Term Integrated Forecasting System, Fourth Quarter 1996, and Model GASCAP94 C110196. 
Table 9. California (Including Pacific OCS) Dry Gas Production and Wellhead Productive Capacity, 1985-1995 (Million Cubic Feet Per Day)

\begin{tabular}{|c|c|c|c|c|c|c|}
\hline \multirow[b]{2}{*}{ Month-Year } & \multirow[b]{2}{*}{$\begin{array}{c}\text { Dry } \\
\text { Production }\end{array}$} & \multicolumn{5}{|c|}{ Dry Gas Productive Capacity } \\
\hline & & $\begin{array}{c}\text { Gas-Well } \\
\text { Gas }\end{array}$ & $\begin{array}{c}\text { Oil-Well } \\
\text { Gas }\end{array}$ & $\begin{array}{c}\text { Total } \\
\text { Gas } \\
\end{array}$ & $\begin{array}{c}\text { Total } \\
\text { Surplus }\end{array}$ & $\begin{array}{l}\text { Utllization } \\
\text { (percent) }\end{array}$ \\
\hline Jan-85 & 1,335 & 803 & 751 & 1,554 & 219 & 85.9 \\
\hline Jun-85 & 1,269 & 750 & 770 & 1,520 & 251 & 83.5 \\
\hline Dec-85 & 1,337 & 740 & 786 & 1,526 & 189 & 87.6 \\
\hline Jan-86 & 1,347 & 765 & 775 & 1,540 & 193 & 87.5 \\
\hline Jun-86 & 1,231 & 687 & 734 & 1,421 & 190 & 86.6 \\
\hline Dec-86 & 1,175 & 620 & 703 & 1,323 & 148 & 88.8 \\
\hline Jan-87 & 1,165 & 583 & 696 & 1,279 & 114 & 91.1 \\
\hline Jun-87 & 1,120 & 541 & 714 & 1,255 & 135 & 89.2 \\
\hline Dec-87 & 1,086 & 491 & 707 & 1,198 & 112 & 90.7 \\
\hline Jan-88 & 1,065 & 495 & 695 & 1,190 & 125 & 89.5 \\
\hline Jun-88 & 1,071 & 473 & 692 & 1,165 & 94 & 91.9 \\
\hline Dec-88 & 996 & 435 & 655 & 1,090 & 94 & 91.4 \\
\hline Jan-89 & 979 & 424 & 659 & 1,083 & 104 & 90.4 \\
\hline Jun-89 & 951 & 404 & 658 & 1,062 & 111 & 89.5 \\
\hline Dec-89 & 940 & 398 & 648 & 1,046 & 106 & 89.9 \\
\hline Jan-90 & 954 & 436 & 652 & 1,088 & 134 & 87.7 \\
\hline Jun-90 & 933 & 471 & 638 & 1,109 & 176 & 84.1 \\
\hline Dec-90 & 976 & 583 & 637 & 1,220 & 244 & 80.0 \\
\hline Jan-91 & 984 & 594 & 625 & 1,219 & 235 & 80.7 \\
\hline Jun-91 & 1,005 & 558 & 628 & 1,186 & 181 & 84.7 \\
\hline Dec-91 & 1,013 & 514 & 635 & 1,149 & 136 & 88.2 \\
\hline Jan-92 & 1,030 & 527 & 632 & 1,159 & 129 & 88.9 \\
\hline Jun-92 & 950 & 457 & 630 & 1,087 & 137 & 87.4 \\
\hline Dec-92 & 913 & 419 & 628 & 1,047 & 134 & 87.2 \\
\hline Jan-93 & 852 & 433 & 575 & 1,008 & 156 & 84.5 \\
\hline Jun-93 & 806 & 408 & 579 & 987 & 181 & 81.7 \\
\hline Dec-93 & 828 & 380 & 588 & 968 & 140 & 85.5 \\
\hline Jan-94 & 838 & 429 & 574 & 1,003 & 165 & 83.5 \\
\hline Jun-94 & 807 & 387 & 576 & 963 & 156 & 83.8 \\
\hline Dec-94 & 807 & 343 & 601 & 944 & 137 & 85.5 \\
\hline Jan- $95^{*}$ & 826 & 336 & 588 & 924 & 98 & 89.4 \\
\hline Jun-95" & 779 & 330 & 597 & 927 & 148 & 84.0 \\
\hline Dec-95" & 864 & 339 & 600 & 939 & 75 & 92.0 \\
\hline
\end{tabular}

"The 1995 estimated history is based on Model GASCAP94 C110196 projections and Baker Hughes rig counts.

Sources: Production History: Energy Information Administration, Office of Oil and Gas; Dwight's Energydata, Inc.; and Model GASCAP94 C11016. Productive Capacity: Model GASCAP94 C110196. 
Table 10. Callfornia (Including Pacific OCS) Dry Gas Production and Wellhead Productive Capacity Projections, 1996-1997 (Million Cubic Feet Per Day)

\begin{tabular}{|c|c|c|c|c|c|c|}
\hline \multirow[b]{2}{*}{ Month-Year } & \multirow[b]{2}{*}{$\begin{array}{c}\text { Dry } \\
\text { Production }\end{array}$} & \multicolumn{5}{|c|}{ Dry Gas Productive Capacity } \\
\hline & & $\begin{array}{c}\text { Gas-Well } \\
\text { Gas }\end{array}$ & $\begin{array}{c}\text { Oll-Well } \\
\text { Gas }\end{array}$ & $\begin{array}{c}\text { Total } \\
\text { Gas } \\
\end{array}$ & $\begin{array}{c}\begin{array}{c}\text { Total } \\
\text { Surplus }\end{array} \\
\end{array}$ & $\begin{array}{l}\text { Utllization } \\
\text { (percent) }\end{array}$ \\
\hline & \multicolumn{6}{|c|}{ Low Case Projection } \\
\hline Jan-96 & 851 & 334 & 598 & 932 & 81 & 91.3 \\
\hline Jun-96 & 804 & 333 & 609 & 942 & 138 & 85.4 \\
\hline Dec-96 & 891 & 341 & 591 & 932 & 41 & 95.6 \\
\hline Jan-97 & 900 & 335 & 585 & 920 & 20 & 97.8 \\
\hline Jun-97 & 829 & 318 & 571 & 889 & 60 & 93.3 \\
\hline \multirow[t]{2}{*}{ Dec-97 } & 859 & 303 & 556 & 859 & 0 & 100.0 \\
\hline & \multicolumn{6}{|c|}{ Base Case Projection } \\
\hline Jan-96 & 851 & 334 & 598 & 932 & 81 & 91.3 \\
\hline Jun-96 & 804 & 333 & 609 & 942 & 138 & 85.4 \\
\hline Dec-96 & 891 & 344 & 601 & 945 & 54 & 94.3 \\
\hline Jan-97 & 899 & 340 & 599 & 939 & 40 & 95.7 \\
\hline Jun-97 & 829 & 331 & 592 & 923 & 94 & 89.8 \\
\hline \multirow[t]{2}{*}{ Dec-97 } & 916 & 330 & 586 & 916 & 0 & 100.0 \\
\hline & \multicolumn{6}{|c|}{ High Case Projection } \\
\hline Jan-96 & 851 & 334 & 598 & 932 & 81 & 91.3 \\
\hline Jun-96 & 804 & 333 & 609 & 942 & 138 & 85.4 \\
\hline Dec-96 & 890 & 345 & 610 & 955 & 65 & 93.2 \\
\hline Jan-97 & 899 & 342 & 613 & 955 & 56 & 94.1 \\
\hline Jun-97 & 829 & 343 & 609 & 952 & 123 & 87.1 \\
\hline Dec-97 & 918 & 360 & 609 & 969 & 51 & 94.7 \\
\hline
\end{tabular}

Sources: Production Projections: Energy Information Administration, short-1erm Integrated Forecasting System, Fourth Quarter 1996, and Model GASCAP94 C110196. Productive Capacity Projections: Model GASCAP94 C110196. 
Figure 22. California (Including Pacific OCS) Gas-Well Completions Added During Year, 1985-1997

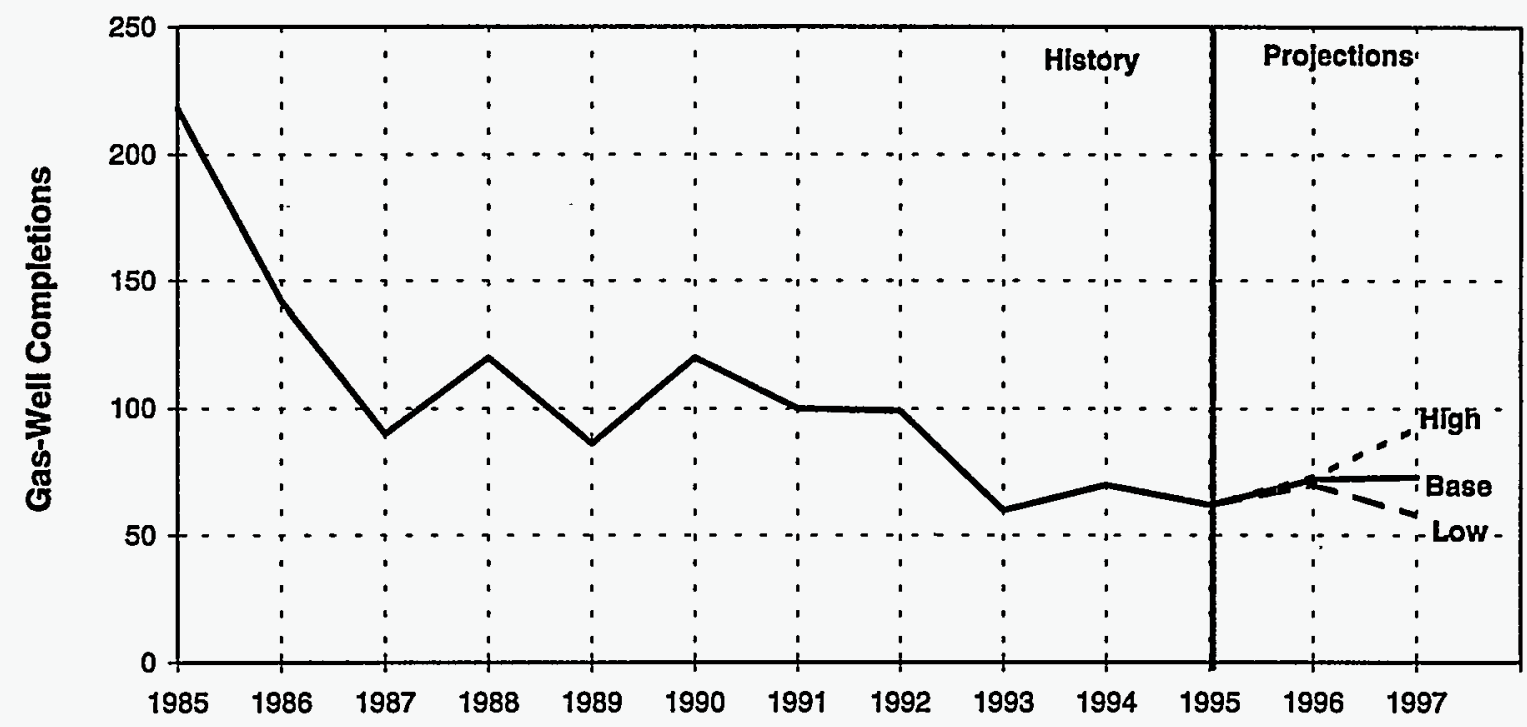

Note: The 1995 estimated history is based on Drilling Rig Model projectlons and Baker Hughes rig counts. Completions include recompletions in new producing zones.

Sources: History: Energy Information Administration, Office of Oll and Gas; Dwight's Energydata, Inc. Projections: Model GASCAP94 C110196.

Figure 23. Percent of Total Wellhead Productive Capacity of California (Including Paclfic OCS) Gas Wells by Well Age, 1985-1997 (Base Case)

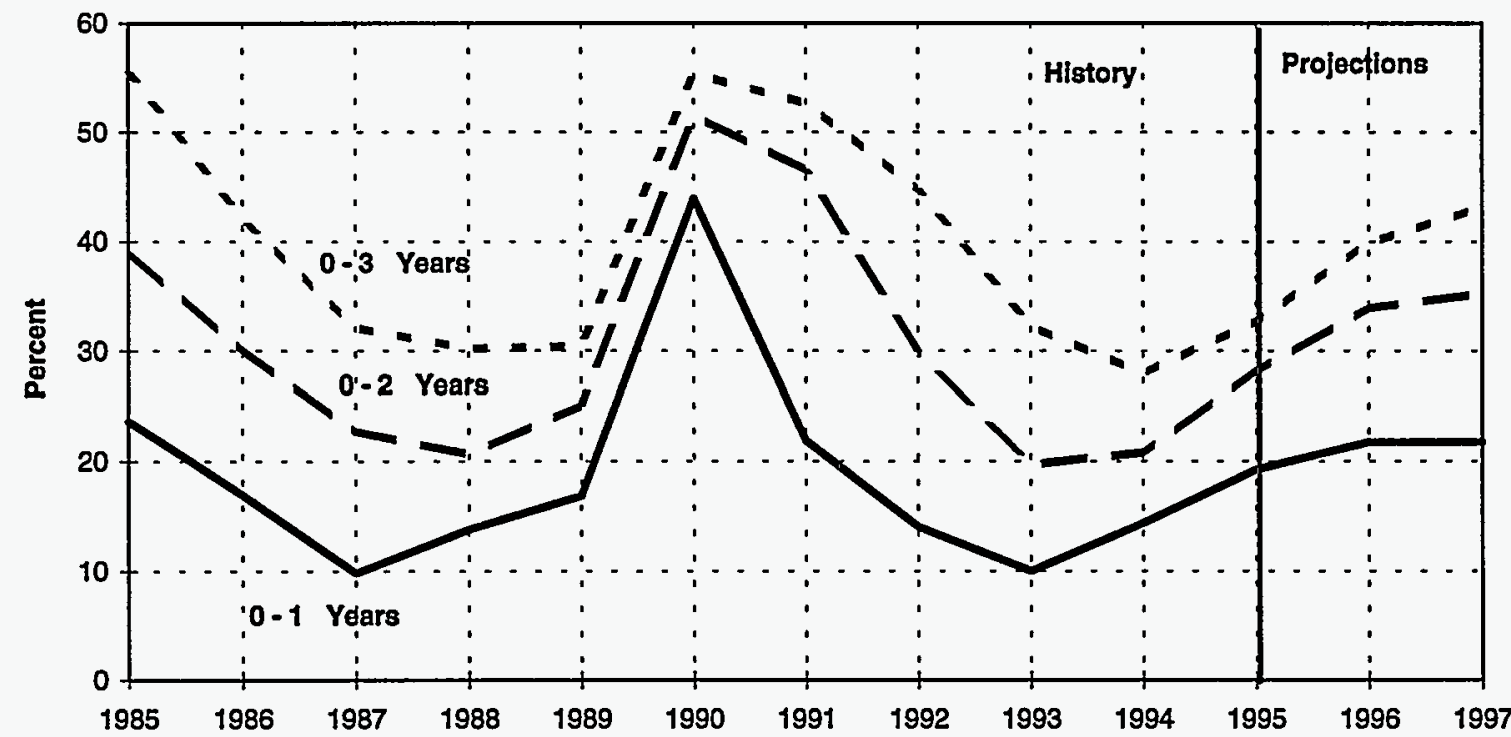

Sources: History: Energy Information Administration, Office of Oll and Gas; Dwight's Energydata, Inc. Projections: Model GASCAP94 C110196. 


\section{Kansas}

In 1994 over half the gas produced in the State of Kansas came from the giant Hugoton field. Hugoton field 1994 production of 419 billion cubic feet of gas was almost 3 percent more than in 1993 and over 29 percent more than five years earlier in 1990. This information was obtained from Dwight's. Hugoton field occupies almost all of the western half of Kansas and extends south into Oklahoma and the northern part of the Texas
Panhandle. Production from this field generally comes from low permeability sandy carbonate reservoir rocks.

The following pages include Tables 11, 12, and Figures 24 through 26 . These data provide historical and projected production and productive capacity, gas-well completions added, and percent of capacity by well age.

Figure 24. Kansas Dry Gas Monthly Production Rate and Wellhead Productive Capacity, 1985-1997

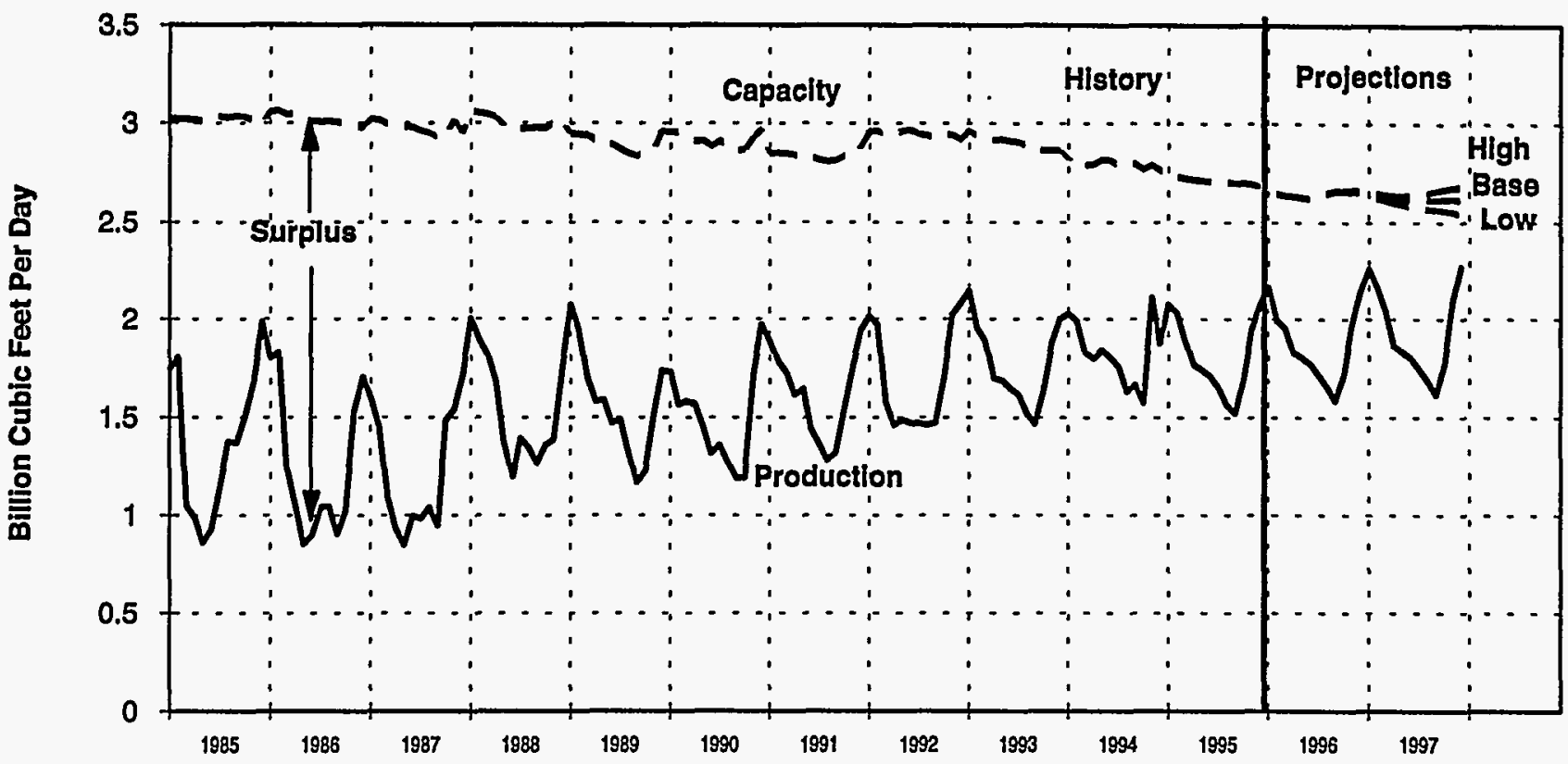

Note: Production projection plotted for base case only. The 1995 estimated history is based on Model GASCAP94 C110196 projections.

Sources: Production History: Energy Information Administration, Office of Oil and Gas; Dwight's Energydata, Inc.; and Model GASCAP94 C110196. Productive Capacity: Model GASCAP94 C110196. Production Projections: Energy Information Administration, Short-Term Integrated Forecasting System, Fourth Quarter 1996, and Model GASCAP94 C110196. 
Table 11. Kansas Dry Gas Production and Wellhead Productive Capacity, 1985-1995 (Million Cubic Feet Per Day)

\begin{tabular}{|c|c|c|c|c|c|c|}
\hline \multirow[b]{2}{*}{ Month-Year } & \multirow[b]{2}{*}{$\begin{array}{c}\text { Dry } \\
\text { Production }\end{array}$} & \multicolumn{5}{|c|}{ Dry Gas Productive Capacity } \\
\hline & & $\begin{array}{c}\text { Gas-Well } \\
\text { Gas }\end{array}$ & $\begin{array}{c}\text { Oil-Well } \\
\text { Gas }\end{array}$ & $\begin{array}{l}\text { Total } \\
\text { Gas }\end{array}$ & $\begin{array}{c}\text { Total } \\
\text { Surplus }\end{array}$ & $\begin{array}{l}\text { Utilization } \\
\text { (percent) }\end{array}$ \\
\hline Jan-85 & 1,749 & 2,798 & 227 & 3,025 & 1,276 & 57.8 \\
\hline Jun-85 & 928 & 2,792 & 233 & 3,025 & 2,097 & 30.7 \\
\hline Dec-85 & 1,981 & 2,749 & 241 & 2,990 & 1,009 & 66.3 \\
\hline Jan-86 & 1,806 & 2,772 & 287 & 3,059 & 1,253 & 59.0 \\
\hline Jun-86 & 897 & 2,762 & 245 & 3,007 & 2,110 & 29.8 \\
\hline Dec-86 & 1,702 & 2,751 & 226 & 2,977 & 1,275 & 57.2 \\
\hline Jan-87 & 1,597 & 2,766 & 251 & 3,017 & 1,420 & 52.9 \\
\hline Jun-87 & 994 & 2,727 & 252 & 2,979 & 1,985 & 33.4 \\
\hline Dec-87 & 1,719 & 2,704 & 248 & 2,952 & 1,233 & 58.2 \\
\hline Jan-88 & 2,002 & 2,775 & 281 & 3,056 & 1,054 & 65.5 \\
\hline Jun-88 & 1,198 & 2,676 & 302 & 2,978 & 1,780 & 40.2 \\
\hline Dec-88 & 1,753 & 2,735 & 279 & 3,014 & 1,261 & 58.2 \\
\hline Jan-89 & 2,071 & 2,700 & 248 & 2,948 & 877 & 70.3 \\
\hline Jun-89 & 1,472 & 2,652 & 244 & 2,896 & 1,424 & 50.8 \\
\hline Dec-89 & 1,736 & 2,741 & 218 & 2,959 & 1,223 & 58.7 \\
\hline Jan-90 & 1,729 & 2,678 & 279 & 2,957 & 1,228 & 58.5 \\
\hline Jun-90 & 1,316 & 2,613 & 275 & 2,888 & 1,572 & 45.6 \\
\hline Dec-90 & 1,970 & 2,699 & 268 & 2,967 & 997 & 66.4 \\
\hline Jan-91 & 1,888 & 2,649 & 200 & 2,849 & 961 & 66.3 \\
\hline Jun-91 & 1,442 & 2,628 & 202 & 2,830 & 1,388 & 51.0 \\
\hline Dec-91 & 1,941 & 2,690 & 193 & 2,883 & 942 & 67.3 \\
\hline Jan-92 & 2,014 & 2,745 & 215 & 2,960 & 946 & 68.0 \\
\hline Jun-92 & 1,472 & 2,762 & 205 & 2,967 & 1,495 & 49.6 \\
\hline Dec-92 & 2,079 & 2,722 & 200 & 2,922 & 843 & 71.1 \\
\hline Jan-93 & 2,143 & 2,756 & 207 & 2,963 & 820 & 72.3 \\
\hline Jun-93 & 1,647 & 2,691 & 220 & 2,911 & 1,264 & 56.6 \\
\hline Dec-93 & 1,999 & 2,659 & 204 & 2,863 & 864 & 69.8 \\
\hline Jan-94 & 2,027 & 2,603 & 216 & 2,819 & 792 & 71.9 \\
\hline Jun-94 & 1,806 & 2,593 & 222 & 2,815 & 1,009 & 64.2 \\
\hline Dec-94 & 1,877 & 2,550 & 216 & 2,766 & 889 & 67.9 \\
\hline Jan-95 & 2,074 & 2,524 & 211 & 2,735 & 661 & 75.8 \\
\hline Jun-95 & 1,708 & 2,501 & 207 & 2,708 & 1,000 & 63.1 \\
\hline Dec-95 & 2,075 & 2,495 & 189 & 2,684 & 609 & 77.3 \\
\hline
\end{tabular}

\footnotetext{
The 1995 estimated history is based on Model GASCAP94 C110196 projections and Baker Hughes rig counts.

Sources: Production History: Energy Information Administration, Office of Oil and Gas; Dwight's Energydata, Inc.; and Model GASCAP94 C11016. Productive Capacity: Model GASCAP94 C110196.
} 
Table 12. Kansas Dry Gas Production and Wellhead Productive Capacity Projections, 1996-1997 (Million Cubic Feet Per Day)

\begin{tabular}{|c|c|c|c|c|c|c|}
\hline \multirow[b]{2}{*}{ Month-Year } & \multirow[b]{2}{*}{$\begin{array}{c}\text { Dry } \\
\text { Production }\end{array}$} & \multicolumn{5}{|c|}{ Dry Gas Productive Capacity } \\
\hline & & $\begin{array}{c}\text { Gas-Well } \\
\text { Gas }\end{array}$ & $\begin{array}{c}\text { Oil-Well } \\
\text { Gas }\end{array}$ & $\begin{array}{l}\text { Total } \\
\text { Gas } \\
\end{array}$ & $\begin{array}{c}\text { Total } \\
\text { Surplus } \\
\end{array}$ & $\begin{array}{l}\text { Utillzation } \\
\text { (percent) }\end{array}$ \\
\hline & \multicolumn{6}{|c|}{ Low Case Projection } \\
\hline Jan-96 & 2,164 & 2,475 & 191 & 2,666 & 502 & 81.2 \\
\hline Jun-96 & 1,770 & 2,430 & 192 & 2,622 & 852 & 67.5 \\
\hline Dec-96 & 2,143 & 2,468 & 185 & 2,653 & 510 & 80.8 \\
\hline Jan-97 & 2,256 & 2,457 & 183 & 2,640 & 384 & 85.5 \\
\hline Jun-97 & 1,801 & 2,407 & 178 & 2,585 & 784 & 69.7 \\
\hline \multirow[t]{2}{*}{ Dec-97 } & 2,303 & 2,372 & 172 & 2,544 & 241 & 90.5 \\
\hline & \multicolumn{6}{|c|}{ Base Case Projection } \\
\hline Jan-96 & 2,164 & 2,475 & 191 & 2,666 & 502 & 81.2 \\
\hline Jun-96 & 1,770 & 2,431 & 192 & 2,623 & 853 & 67.5 \\
\hline Dec-96 & 2,141 & 2,471 & 189 & 2,660 & 519 & 80.5 \\
\hline Jan-97 & 2,254 & 2,462 & 188 & 2,650 & 396 & 85.1 \\
\hline Jun-97 & 1,801 & 2,434 & 185 & 2,619 & 818 & 68.8 \\
\hline \multirow[t]{2}{*}{ Dec-97 } & 2,268 & 2,435 & 183 & 2,618 & 350 & 86.6 \\
\hline & \multicolumn{6}{|c|}{ High Case Projection } \\
\hline Jan-96 & 2,164 & 2,475 & 191 & 2,666 & 502 & 81.2 \\
\hline Jun-96 & 1,770 & 2,431 & 192 & 2,623 & 853 & 67.5 \\
\hline Dec-96 & 2,140 & 2,471 & 192 & 2,663 & 523 & 80.4 \\
\hline Jan-97 & 2,254 & 2,461 & 193 & 2,654 & 400 & 84.9 \\
\hline Jun-97 & 1,801 & 2,450 & 191 & 2,641 & 840 & 68.2 \\
\hline Dec-97 & 2,240 & 2,492 & 191 & 2,683 & 443 & 83.5 \\
\hline
\end{tabular}

Sources: Production Projections: Energy Information Administration, Short-Term Integrated Forecasting System, Fourth Quarter 1996, and Model GASCAP94 C110196. Productive Capacity Projections: Model GASCAP94 C110196. 
Figure 25. Kansas Gas-Well Completions Added During Year, 1985-1997

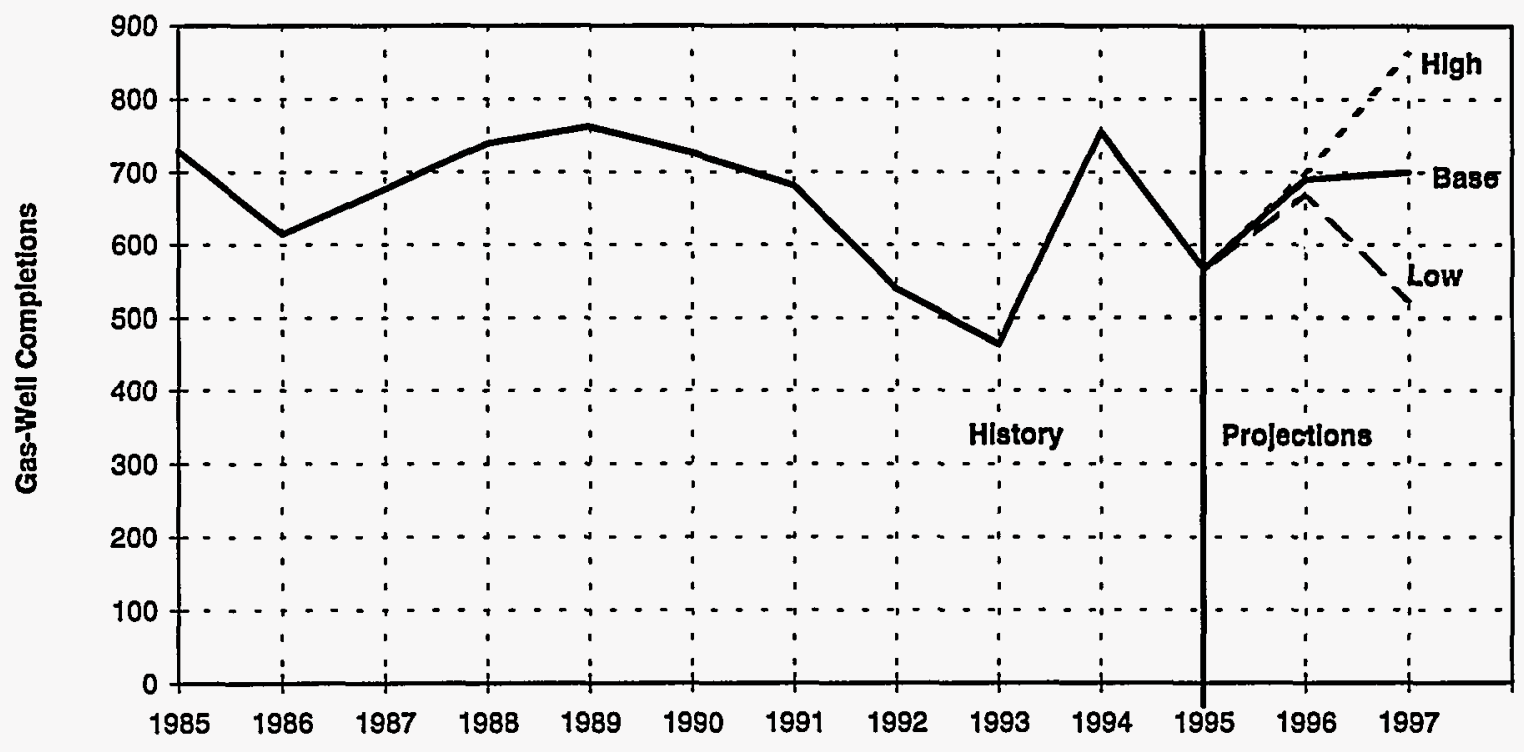

Note: The 1995 estlmated history is based on Drilling Rig Model projectlons and Baker Hughes rig counts. Completions include recompletions In new producing zones.

Sources: History: Energy Information Administration, Office of Oll and Gas; Dwight's Energydata, Inc. Projections: Model GASCAP94 C110196.

Figure 26. Percent of Total Wellhead Productive Capacity of Kansas Gas Wells by Well Age, 1985-1997 (Base Case)

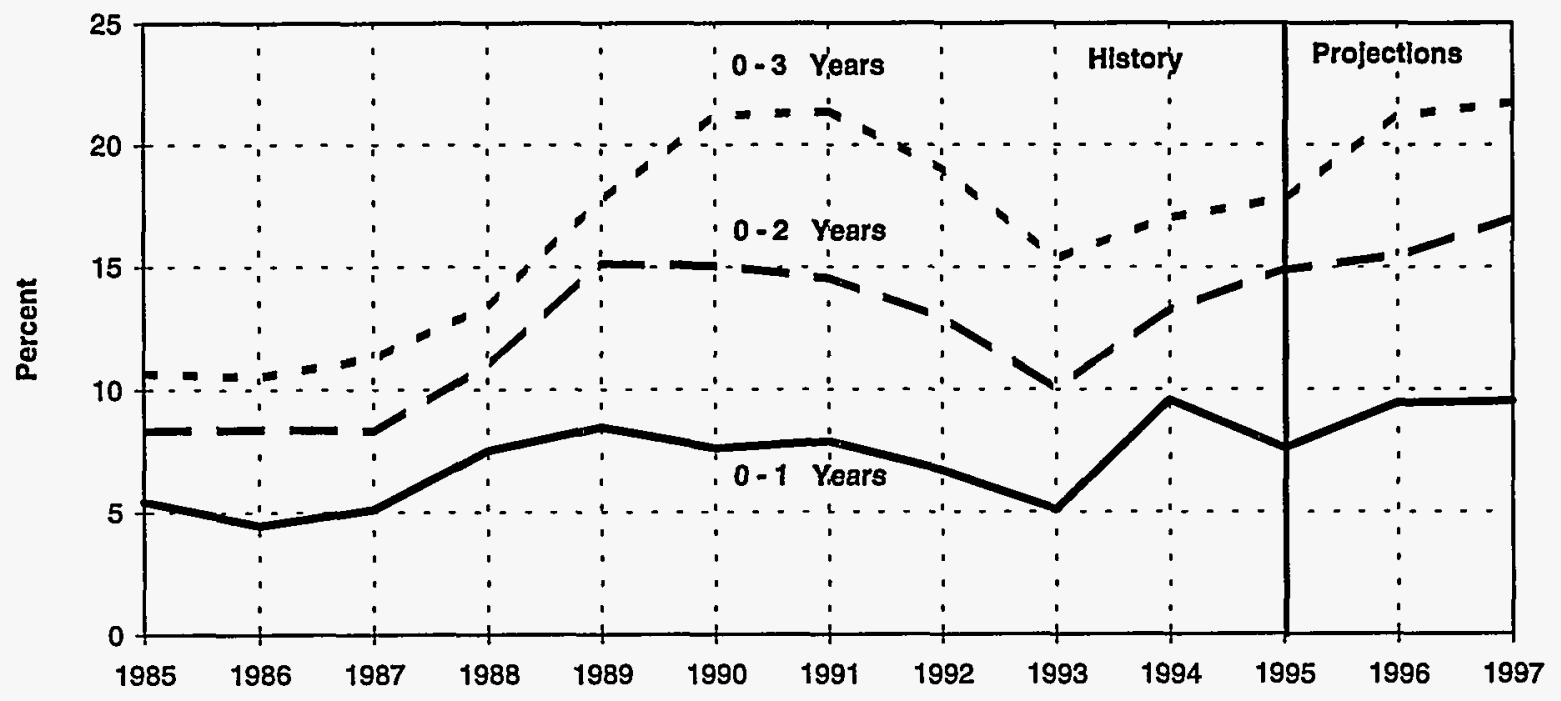

Sources: History: Energy information Administration, Office of Oil and Gas; Dwight's Energydata, Inc. Projections: Model GASCAP94 C110196. 


\section{New Mexico}

Most of this State's natural gas is produced from fields in northwestern New Mexico from the San Juan Basin. San Juan Basin gas production increased from 536 billion cubic feet in 1990 to 1,138 billion in 1994 . Practically all of the oil-well gas produced comes from the Permian Basin of southeast New Mexico.

Basin field, the largest gas field in the State, produced 680 billion cubic feet of mixed gas-well conventional and coalbed gas during 1994. This was an increase of 44 billion cubic feet over the amount produced in 1993. New Mexico has been an area of intense drilling for coalbed gas since 1989. Coalbed gas production from this field increased 217 percent from 1990 through 1994.

It is expected that, with the current reduction in new well completions, gas production from this area is near its peak. Drilling dramatically decreased in 1993 after the Section 29 gas tax credit expired.

Coalbed gas producted in New Mexico was about 15 percent of the State's total dry gas producted in 1990, 23 percent in 1991, 31 percent in 1992, 36 percent in 1993, and 39 percent in 1994.\{12\} Coalbed gas-well completions were treated separately from the conventional gas-well completions in this report. Coalbed gas wells have an increasing rate of production the first few years of their lives. After reaching their peak production rates, coalbed gas wells are predicted to have very low decline rates and therefore very long lives. Coalbed gas capacity has shown an increase in the last few years. (Figure 28).

There is a decrease in the New Mexico total gas-well completions for 1996 and an increase in 1977. In 1996, the number of drilling rigs in New Mexico decreased. A decrease in the number of gas-well completions resulted, because the number of completions is a function of the number of rigs. Rigs are forecast to increase in 1997 for the base and high cases and decrease for the low case for the lower 48 States.After taking into account the completion per rig and State distribution factors, the New Mexico total gas-well completions are expected to increase in 1997.

The following pages include Tables 13,14 , and Figures 27 through 30, which provide historical and projected production and productive capacity, gas-well completions added, and percent of capacity by well age.

Flgure 27. New Mexico Dry Gas Monthly Production Rate and Wellhead Productive Capacity, 1985-1997

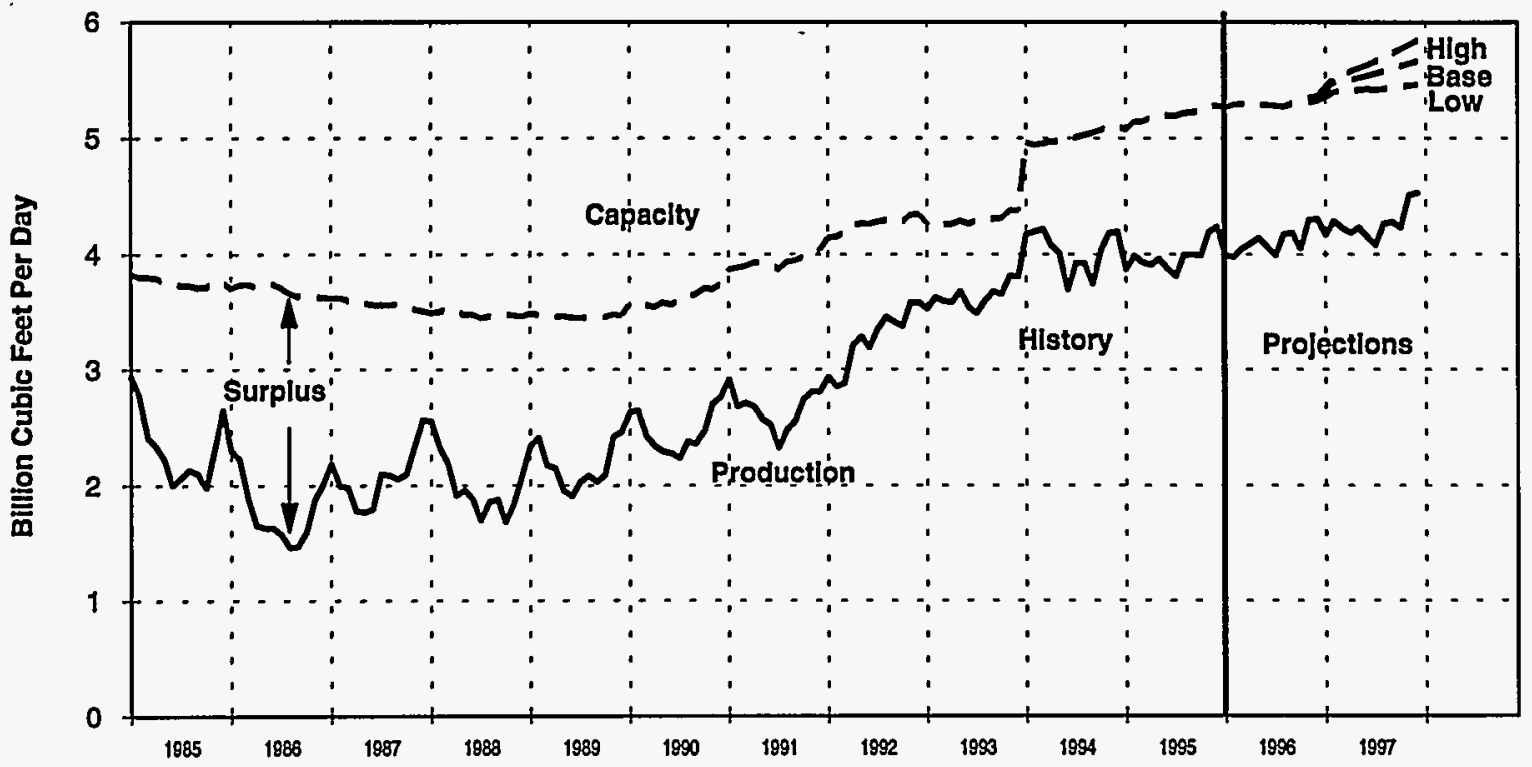

Note: Production projection plotted for base case only. The 1995 estimated history is based on Model GASCAP94 C110196 projections.

Sources: Production History: Energy Information Administration, Office of Oll and Gas; Dwight's Energydata, Inc.; and Model GASCAP94 C110196. Productive Capacity: Model GASCAP94 C110196. Production Projections: Energy Information Administration, Short-Term Integrated Forecasting System, Fourth Quarter 1996, and Model GASCAP94 C110196. 
Table 13. New Mexico Dry Gas Production and Wellhead Productive Capacity, 1985-1995 (Million Cubic Feet Per Day)

\begin{tabular}{|c|c|c|c|c|c|c|}
\hline \multirow[b]{2}{*}{ Month-Year } & \multirow[b]{2}{*}{$\begin{array}{c}\text { Dry } \\
\text { Production } \\
\end{array}$} & \multicolumn{4}{|c|}{ Dry Gas Productive Capacity } & \multirow[b]{2}{*}{$\begin{array}{l}\text { Utilization } \\
\text { (percent) }\end{array}$} \\
\hline & & $\begin{array}{l}\text { Gas-Well } \\
\text { Gas }\end{array}$ & $\begin{array}{c}\text { Oil-Well } \\
\text { Gas }\end{array}$ & $\begin{array}{l}\text { Total } \\
\text { Gas }\end{array}$ & $\begin{array}{c}\text { Total } \\
\text { Surplus }\end{array}$ & \\
\hline Jan-85 & 2,939 & 3,267 & 561 & 3,828 & 889 & 76.8 \\
\hline Jun-85 & 2,003 & 3,203 & 548 & 3,751 & 1,748 & 53.4 \\
\hline Dec-85 & 2,647 & 3,206 & 554 & 3,760 & 1,113 & 70.4 \\
\hline Jan-86 & 2,305 & 3,136 & 574 & 3,710 & 1,405 & 62.1 \\
\hline Jun-86 & 1,629 & 3,191 & 551 & 3,742 & 2,113 & 43.5 \\
\hline Dec-86 & 2,007 & 3,105 & 521 & 3,626 & 1,619 & 55.4 \\
\hline Jan-87 & 2,188 & 3,089 & 536 & 3,625 & 1,437 & 60.4 \\
\hline Jun-87 & $1 ; 795$ & 3,039 & 525 & 3,564 & 1,769 & 50.4 \\
\hline Dec-87 & 2,569 & 2,972 & 539 & 3,511 & 942 & 73.2 \\
\hline Jan-88 & 2,554 & 2,973 & 524 & 3,497 & 943 & 73.0 \\
\hline Jun-88 & 1,879 & 2,967 & 512 & 3,479 & 1,600 & 54.0 \\
\hline Dec-88 & 2,101 & 2,962 & 503 & 3,465 & 1,364 & 60.6 \\
\hline Jan-89 & 2,347 & 2,988 & 501 & 3,489 & 1,142 & 67.3 \\
\hline Jun-89 & 1,907 & 2,981 & 472 & 3,453 & 1,546 & 55.2 \\
\hline Dec-89 & 2,468 & 3,014 & 458 & 3,472 & 1,004 & 71.1 \\
\hline Jan-90 & 2,626 & 3,062 & 508 & 3,570 & 944 & 73.6 \\
\hline Jun-90 & 2,282 & 3,076 & 491 & 3,567 & 1,285 & 64.0 \\
\hline Dec-90 & 2,762 & 3,233 & 504 & 3,737 & 975 & 73.9 \\
\hline Jan-91 & 2,910 & 3,317 & 551 & 3,868 & 958 & 75.2 \\
\hline Jun-91 & 2,526 & 3,373 & 539 & 3,912 & 1,386 & 64.6 \\
\hline Dec-91 & 2,810 & 3,486 & 547 & 4,033 & 1,223 & 69.7 \\
\hline Jan-92 & 2,931 & 3,579 & 563 & 4,142 & 1,211 & 70.8 \\
\hline Jun-92 & 3,192 & 3,696 & 564 & 4,260 & 1,068 & 74.9 \\
\hline Dec-92 & 3,585 & 3,790 & 553 & 4,343 & 758 & 82.5 \\
\hline Jan-93 & 3,531 & 3,693 & 565 & 4,258 & 727 & 82.9 \\
\hline Jun-93 & 3,545 & 3,707 & 556 & 4,263 & 718 & 83.2 \\
\hline Dec-93 & 3,808 & 3,805 & 571 & 4,376 & 568 & 87.0 \\
\hline Jan-94 & 4,173 & 4,419 & 539 & 4,958 & 785 & 84.2 \\
\hline Jun-94 & 3,696 & 4,492 & 487 & 4,979 & 1,283 & 74.2 \\
\hline Dec-94 & 4,195 & 4,591 & 515 & 5,106 & 911 & 82.2 \\
\hline Jan-95 & 3,870 & 4,569 & 505 & 5,074 & 1,204 & 76.3 \\
\hline Jun-95 & 3,875 & 4,668 & 522 & 5,190 & 1,315 & 74.7 \\
\hline Dec-95 & 4,234 & 4,758 & 519 & 5,277 & 1,043 & 80.2 \\
\hline
\end{tabular}

"The 1995 estimated history is based on Model GASCAP94 C110196 projections and Baker Hughes rig counts.

Sources: Production History: Energy Information Administration, Office of Oil and Gas; Dwight's Energydata, Inc.; and Model GASCAP94 C11016. Productive Capacity: Model GASCAP94 C110196. 
Table 14. New Mexico Dry Gas Production and Wellhead Productive Capacity Projections, 1996-1997 (Million Cubic Feet Per Day)

\begin{tabular}{|c|c|c|c|c|c|c|}
\hline \multirow[b]{2}{*}{ Month-Year } & \multirow[b]{2}{*}{$\begin{array}{c}\text { Dry } \\
\text { Production }\end{array}$} & \multicolumn{5}{|c|}{ Dry Gas Productive Capacity } \\
\hline & & $\begin{array}{c}\text { Gas-Well } \\
\text { Gas }\end{array}$ & $\begin{array}{c}\text { Oll-Well } \\
\text { Gas }\end{array}$ & $\begin{array}{l}\text { Total } \\
\text { Gas }\end{array}$ & $\begin{array}{c}\text { Total } \\
\text { Surplus }\end{array}$ & $\begin{array}{l}\text { Utilization } \\
\text { (percent) }\end{array}$ \\
\hline & \multicolumn{6}{|c|}{ Low Case Projection } \\
\hline Jan-96 & 3,990 & 4,739 & 524 & 5,263 & 1,273 & 75.8 \\
\hline Jun-96 & 4,061 & 4,755 & 527 & 5,282 & 1,221 & 76.9 \\
\hline Dec-96 & 4,309 & 4,808 & 510 & 5,318 & 1,009 & 81.0 \\
\hline Jan-97 & 4,175 & 4,843 & 504 & 5,347 & 1,172 & 78.1 \\
\hline Jun-97 & 4,154 & 4,927 & 491 & 5,418 & 1,264 & 76.7 \\
\hline \multirow[t]{2}{*}{ Dec-97 } & 4,599 & 4,978 & 476 & 5,454 & 855 & 84.3 \\
\hline & \multicolumn{6}{|c|}{ Base Case Projection } \\
\hline Jan-96 & 3,990 & 4,739 & 524 & 5,263 & 1,273 & 75.8 \\
\hline Jun-96 & 4,061 & 4,756 & 527 & 5,283 & 1,222 & 76.9 \\
\hline Dec-96 & 4,306 & 4,826 & 520 & 5,346 & 1,040 & 80.5 \\
\hline Jan-97 & 4,170 & 4,881 & 518 & 5,399 & 1,229 & 77.2 \\
\hline Jun-97 & 4,154 & 5,025 & 511 & 5,536 & 1,382 & 75.0 \\
\hline \multirow[t]{2}{*}{ Dec-97 } & 4,528 & 5,154 & 505 & 5,659 & 1,131 & 80.0 \\
\hline & \multicolumn{6}{|c|}{ High Case Projection } \\
\hline Jan-96 & 3,990 & 4,739 & 524 & 5,263 & 1,273 & 75.8 \\
\hline Jun-96 & 4,061 & 4,757 & 527 & 5,284 & 1,223 & 76.9 \\
\hline Dec-96 & 4,304 & 4,835 & 528 & 5,363 & 1,059 & 80.3 \\
\hline Jan-97 & 4,170 & 4,908 & 531 & 5,439 & 1,269 & 76.7 \\
\hline Jun-97 & 4,154 & 5,099 & 528 & 5,627 & 1,473 & 73.8 \\
\hline Dec-97 & 4,472 & 5,311 & 527 & 5,838 & 1,366 & 76.6 \\
\hline
\end{tabular}

Sources: Production Projections: Energy Information Administration, Short-Term Integrated Forecasting System, Fourth Quarter 1996, and Model GASCAP94 C110196. Productive Capacity Projections: Model GASCAP94 C110196. 
Figure 28. New Mexico Dry Coalbed Gas Monthly Production Rate and Wellhead Productive Capacity, 1985-1997

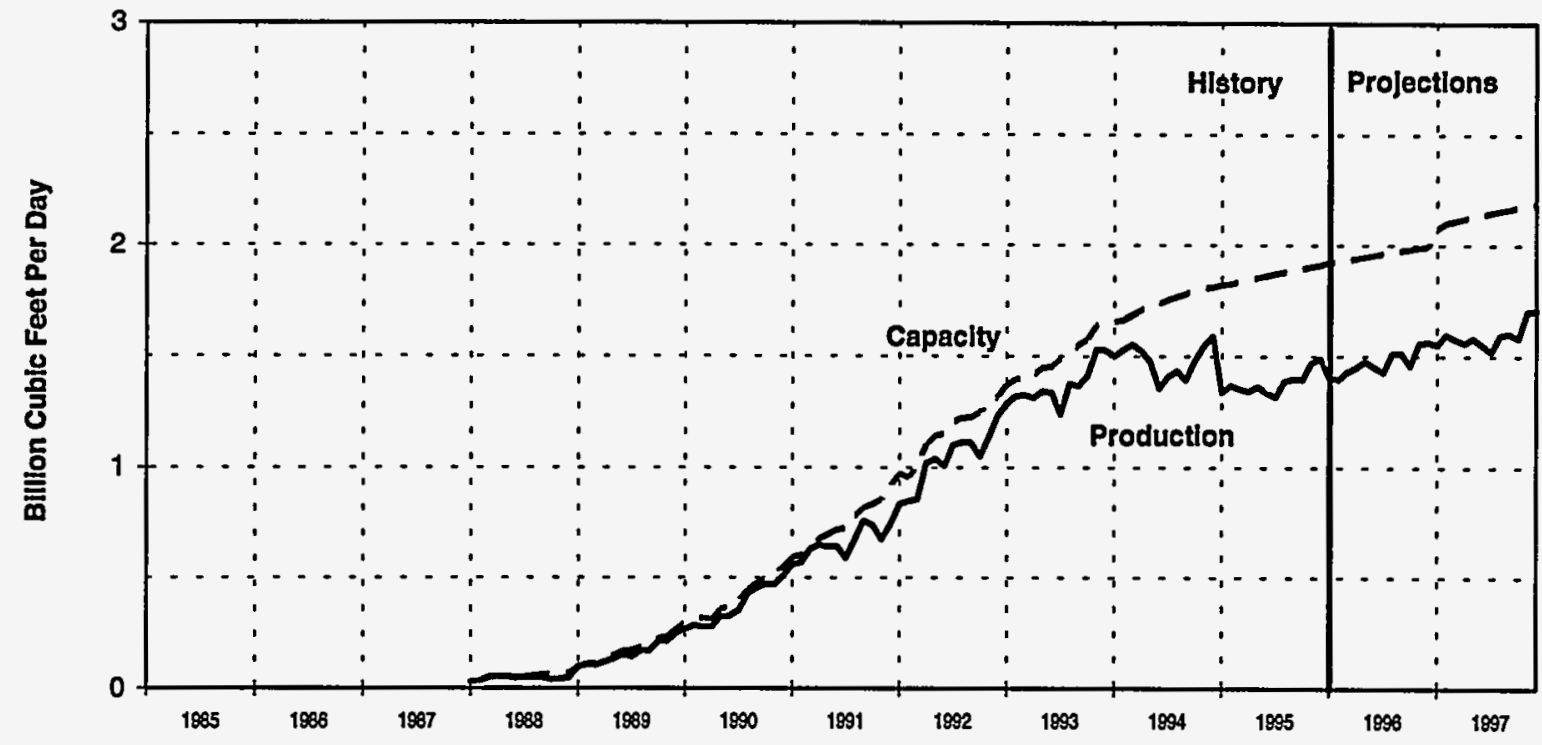

Note: Production projection plotted for base case only.

Sources: Production History: Energy Information Administration, Office of Oil and Gas; Dwight's Energydata, Inc.; and Model GASCAP94 C110196. Productive Capacity: Model GASCAP94 C11016. Production Projections: Energy Information Administration, Short-Term Integrated Forecasting Syștem, Fourth Quarter 1996, and Model GASCAP94 C110196.

Figure 29. New Mexico Gas-Well Completlons Added During Year, 1985-1997

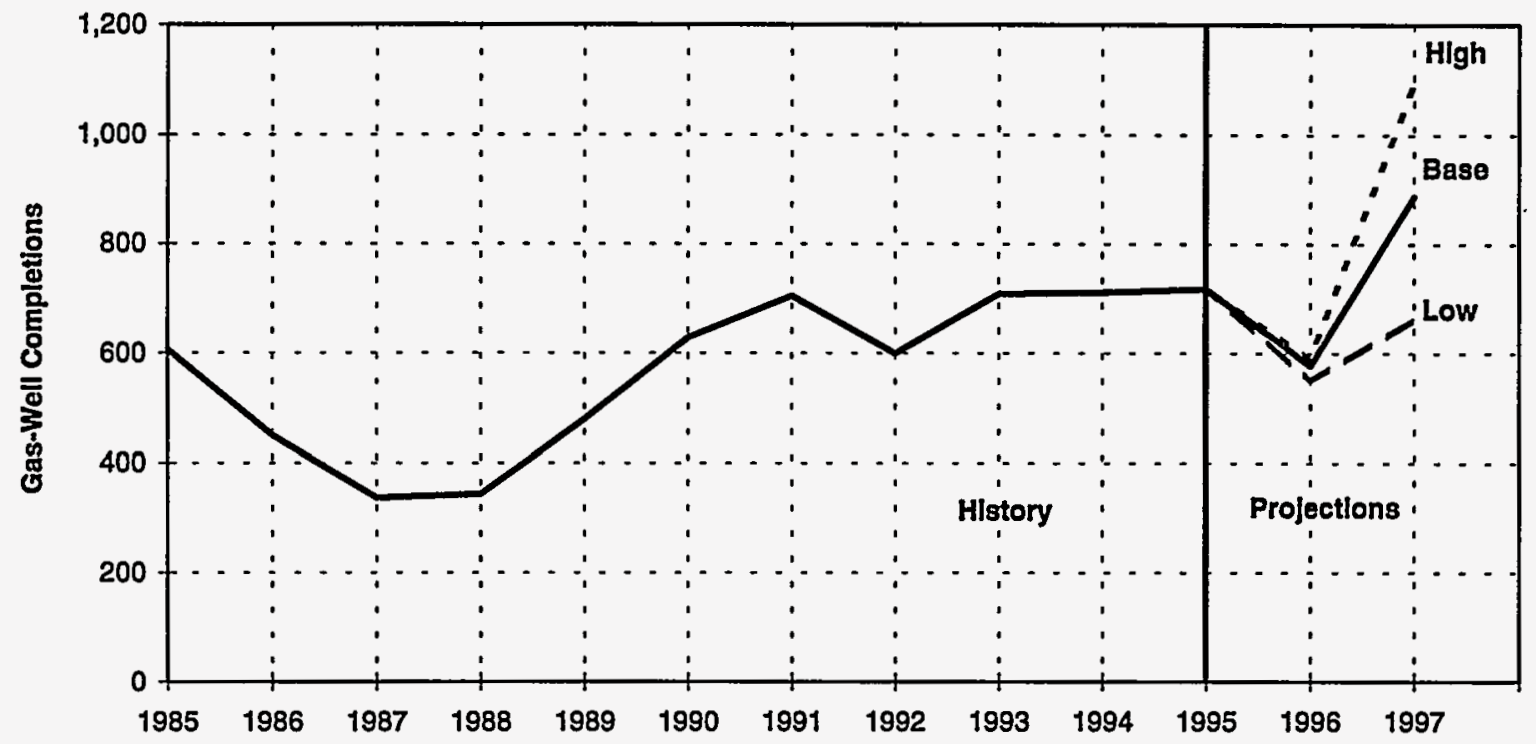

Note: The 1995 estimated history is based on Drilling Rig Model projections and Baker Hughes rig counts. Completions include recompletions in new producing zones.

Sources: History: Energy Information Administration, Office of Oil and Gas; Dwight's Energydata, Inc. Projections: Model GASCAP94 C110196. 
Figure 30. Percent of Total Wellhead Productive Capacity of New Mexico Gas Welis by Well Age, 1985-1997 (Base Case)

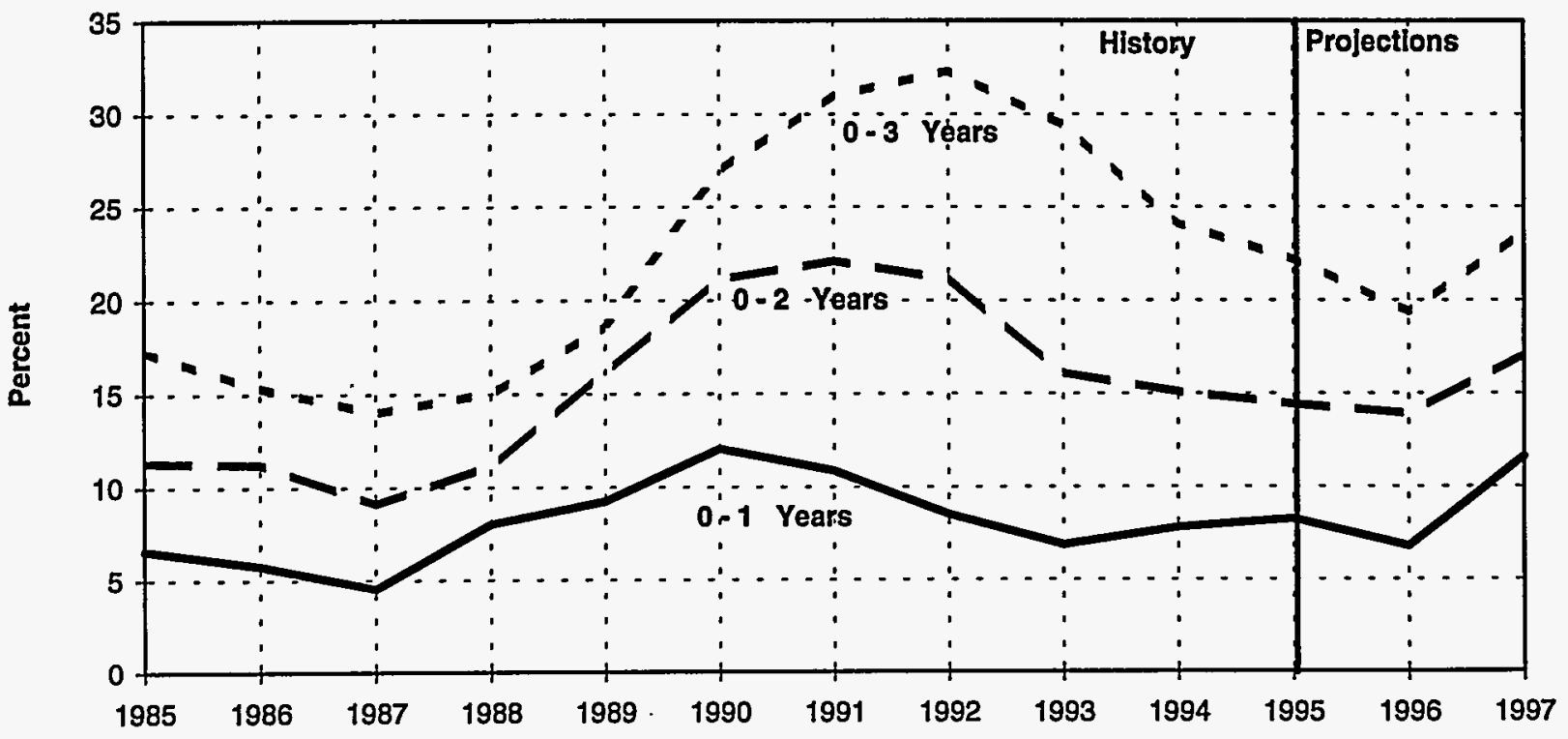

Sources: History: Energy Information Administration, Office of Oil and Gas; Dwight's Energydata, Inc. Projections: Model GASCAP94 C110196. 


\section{Oklahoma}

Oklahoma is among the top three gas-producing States. There are numerous large and small gas fields scattered throughout western Oklahoma. Oil fields with large volumes of associated-dissolved gas are located generally in central Oklahoma. Dwight's EnergyData, Inc., indicates that, in 1994, the top two gas-producing areas were the Mocane-Laverne (99 Bcf) area and the Watonga-Chickasha Trend (92Bcf). The MocaneLaverne area, located in Northwest Oklahoma, consists of over 50 fields, and the Watonga-Chickasha Trend consists of more than 70 fields.

The following pages include Tables 15 and 16 and Figures 31 through 33, which provide historical and projected production and productive capacity, gas-well completions added, and percent of capacity by well age.

Production and capacity are equal, indicating no surplus for some months in 1997. In the low case, no surplus exists for January, February and September through December. For the base case, no surplus exists for January and October through December. For the high case, no surplus exists for November and December. The production is plotted for the base case only in Figure 31.

Figure 31. Oklahoma Dry Gas Monthly Production Rate and Wellhead Productive Capacity, 1985-1997

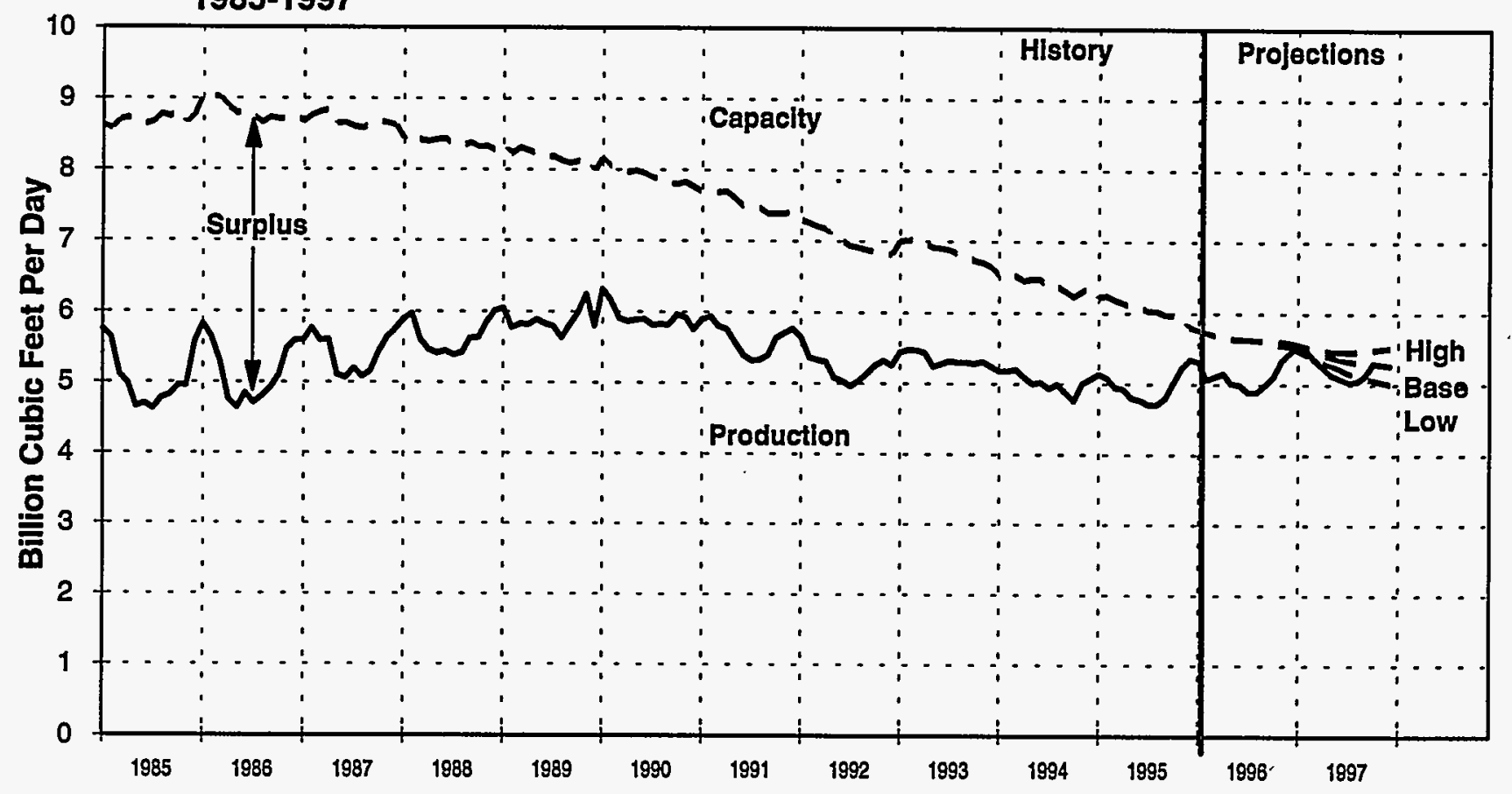

Note: Production projection plotted for base case only. The 1995 estimated history is based on Model GASCAP94 C110196 projections. Sources: Production History: Energy Information Administration, Office of Oll and Gas; Dwight's Energydata, Inc.; and Model GASCAP94 C110196. Produclive Capacity: Model GASCAP94 C110196. Production Projections: Energy Information Administration, Short-Term Integrated Forecasting System, Fourth Quarter 1996, and Model GASCAP94 C110196. 
Table 15. Oklahoma Dry Gas Production and Wellhead Productive Capacity, 1985-1995 (Million Cubic Feet Per Day)

\begin{tabular}{|c|c|c|c|c|c|c|}
\hline \multirow[b]{2}{*}{ Month-Year } & \multirow[b]{2}{*}{$\begin{array}{c}\text { Dry } \\
\text { Production }\end{array}$} & \multicolumn{5}{|c|}{ Dry Gas Productive Capacity } \\
\hline & & $\begin{array}{c}\text { Gas-Well } \\
\text { Gas }\end{array}$ & $\begin{array}{c}\text { Oil-Well } \\
\text { Gas }\end{array}$ & $\begin{array}{l}\text { Total } \\
\text { Gas }\end{array}$ & $\begin{array}{c}\text { Total } \\
\text { Surplus } \\
\end{array}$ & $\begin{array}{l}\text { Utilization } \\
\text { (percent) }\end{array}$ \\
\hline Jan-85 & 5,745 & 7,429 & 1,187 & 8,616 & 2,871 & 66.7 \\
\hline Jun-85 & 4,694 & 7,491 & 1,138 & 8,629 & 3,935 & 54.4 \\
\hline Dec-85 & 5,570 & 7,569 & 1,207 & 8,776 & 3,206 & 63.5 \\
\hline Jan-86 & 5,821 & 7,552 & 1,507 & 9,059 & 3,238 & 64.3 \\
\hline Jun-86 & 4,841 & 7,516 & 1,295 & 8,811 & 3,970 & 54.9 \\
\hline Dec-86 & 5,585 & 7,480 & 1,264 & 8,744 & 3,159 & 63.9 \\
\hline Jan-87 & 5,595 & 7,451 & 1,228 & 8,679 & 3,084 & 64.5 \\
\hline Jun-87 & 5,062 & 7,353 & 1,296 & 8,649 & 3,587 & 58.5 \\
\hline Dec-87 & 5,747 & 7,408 & 1,211 & 8,619 & 2,872 & 66.7 \\
\hline Jan-88 & 5,888 & 7,221 & 1,202 & 8,423 & 2,535 & 69.9 \\
\hline Jun-88 & 5,438 & 7,204 & 1,222 & 8,426 & 2,988 & 64.5 \\
\hline Dec-88 & 6,011 & 7,088 & 1,183 & 8,271 & 2,260 & 72.7 \\
\hline Jan-89 & 6,047 & 7,129 & 1,222 & 8,351 & 2,304 & 72.4 \\
\hline Jun-89 & 5,828 & 7,026 & 1,141 & 8,167 & 2,339 & 71.4 \\
\hline Dec-89 & 5,802 & 6,955 & 1,033 & 7,988 & 2,186 & 72.6 \\
\hline Jan-90 & 6,308 & 6,937 & 1,224 & 8,161 & 1,853 & 77.3 \\
\hline Jun-90 & 5,896 & 6,858 & 1,094 & 7,952 & 2,056 & 74.1 \\
\hline Dec-90 & 5,747 & 6,751 & 1,010 & 7,761 & 2,014 & 74.0 \\
\hline Jan-91 & 5,895 & 6,758 & 940 & 7,698 & 1,803 & 76.6 \\
\hline Jun-91 & 5,395 & 6,552 & 941 & 7,493 & 2,098 & 72.0 \\
\hline Dec-91 & 5,767 & 6,515 & 892 & 7,407 & 1,640 & 77.9 \\
\hline Jan-92 & 5,646 & 6,396 & 902 & 7,298 & 1,652 & 77.4 \\
\hline Jun-92 & 5,036 & 6,113 & 893 & 7,006 & 1,970 & 71.9 \\
\hline Dec-92 & 5,251 & 5,930 & 887 & 6,817 & 1,566 & 77.0 \\
\hline Jan-93 & 5,443 & 6,182 & 824 & 7,006 & 1,563 & 77.7 \\
\hline Jun-93 & 5,275 & 6,054 & 846 & 6,900 & 1,625 & 76.4 \\
\hline Dec-93 & 5,239 & 5,854 & 788 & 6,642 & 1,403 & 78.9 \\
\hline Jan-94 & 5,177 & 5,711 & 820 & 6,531 & 1,354 & 79.3 \\
\hline Jun-94 & 5,015 & 5,646 & 817 & 6,463 & 1,448 & 77.6 \\
\hline Dec-94 & 5,070 & 5,549 & 804 & 6,353 & 1,283 & 79.8 \\
\hline Jan-95" & 5,135 & 5,456 & 767 & 6,223 & 1,088 & 82.5 \\
\hline Jun-95" & 4,769 & 5,300 & 775 & 6,075 & 1,306 & 78.5 \\
\hline Dec-95" & 5,338 & 5,148 & 652 & 5,800 & 462 & 92.0 \\
\hline
\end{tabular}

The 1995 estimated history is based on Model GASCAP94 C110196 projections and Baker Hughes rig counts.

Sources: Production History: Energy Information Administration, Office of Oil and Gas; Dwight's Energydata, Inc.; and Model GASCAP94 C11016. Productive Capacity: Model GASCAP94 C110196: 
Table 16. Oklahoma Dry Gas Production and Wellhead Productive Capacity Projections, 1996-1997 (Million Cubic Feet Per Day)

\begin{tabular}{|c|c|c|c|c|c|c|}
\hline \multirow[b]{2}{*}{ Month-Year } & \multirow[b]{2}{*}{$\begin{array}{c}\text { Dry } \\
\text { Production }\end{array}$} & \multicolumn{5}{|c|}{ Dry Gas Productive Capacity } \\
\hline & & $\begin{array}{c}\text { Gas-Well } \\
\text { Gas }\end{array}$ & $\begin{array}{c}\text { Oll-Well } \\
\text { Gas }\end{array}$ & $\begin{array}{l}\text { Total } \\
\text { Gas }\end{array}$ & $\begin{array}{c}\text { Total } \\
\text { Surplus }\end{array}$ & $\begin{array}{l}\text { Utilization } \\
\text { (percent) }\end{array}$ \\
\hline & \multicolumn{6}{|c|}{ Low Case Projection } \\
\hline Jan-96 & 5,318 & $\overline{5,107}$ & 658 & 5,765 & 447 & 92.2 \\
\hline Jun-96 & 4,990 & 4,972 & 659 & 5,631 & 641 & 88.6 \\
\hline Dec-96 & 5,449 & 4,896 & 634 & 5,530 & 81 & 98.5 \\
\hline Jan-97 & 5,475 & 4,849 & 626 & 5,475 & 0 & 100.0 \\
\hline Jun-97 & 5,085 & 4,610 & 608 & 5,218 & 133 & 97.5 \\
\hline \multirow[t]{2}{*}{ Dec-97 } & 5,006 & 4,420 & 586 & 5,006 & 0 & 100.0 \\
\hline & \multicolumn{6}{|c|}{ Base Case Projection } \\
\hline Jan-96 & 5,318 & 5,107 & 658 & 5,765 & 447 & $\overline{92.2}$ \\
\hline Jun-96 & 4,990 & 4,973 & 659 & 5,632 & 642 & 88.6 \\
\hline Dec-96 & 5,445 & 4,919 & 647 & 5,566 & 121 & 97.8 \\
\hline Jan-97 & 5,527 & 4,883 & 644 & 5,527 & 0 & 100.0 \\
\hline Jun-97 & 5,085 & 4,722 & 632 & 5,354 & 269 & 95.0 \\
\hline \multirow[t]{2}{*}{ Dec-97 } & 5,271 & 4,649 & 622 & 5,271 & 0 & 100.0 \\
\hline & \multicolumn{6}{|c|}{ High Case Projection } \\
\hline Jan-96 & 5,318 & 5,107 & 658 & 5,765 & 447 & 92.2 \\
\hline Jun-96 & 4,990 & 4,974 & 659 & 5,633 & 643 & 88.6 \\
\hline Dec-96 & 5,442 & 4,932 & 657 & 5,589 & 147 & 97.4 \\
\hline Jan-97 & 5,532 & 4,900 & 660 & 5,560 & 28 & 99.5 \\
\hline Jun-97 & 5,085 & 4,801 & 653 & 5,454 & 369 & 93.2 \\
\hline Dec-97 & 5,514 & 4,865 & 649 & 5,514 & 0 & 100.0 \\
\hline
\end{tabular}

Sources: Production Projections: Energy Information Administration, Short-Term Integrated Forecasting System, Fourth Quarter 1996, and Model GASCAP94 C110196. Productive Capacity Projections: Model GASCAP94 C110196. 
Figure 32. Oklahoma Gas-Well Completions Added During Year, 1985-1997

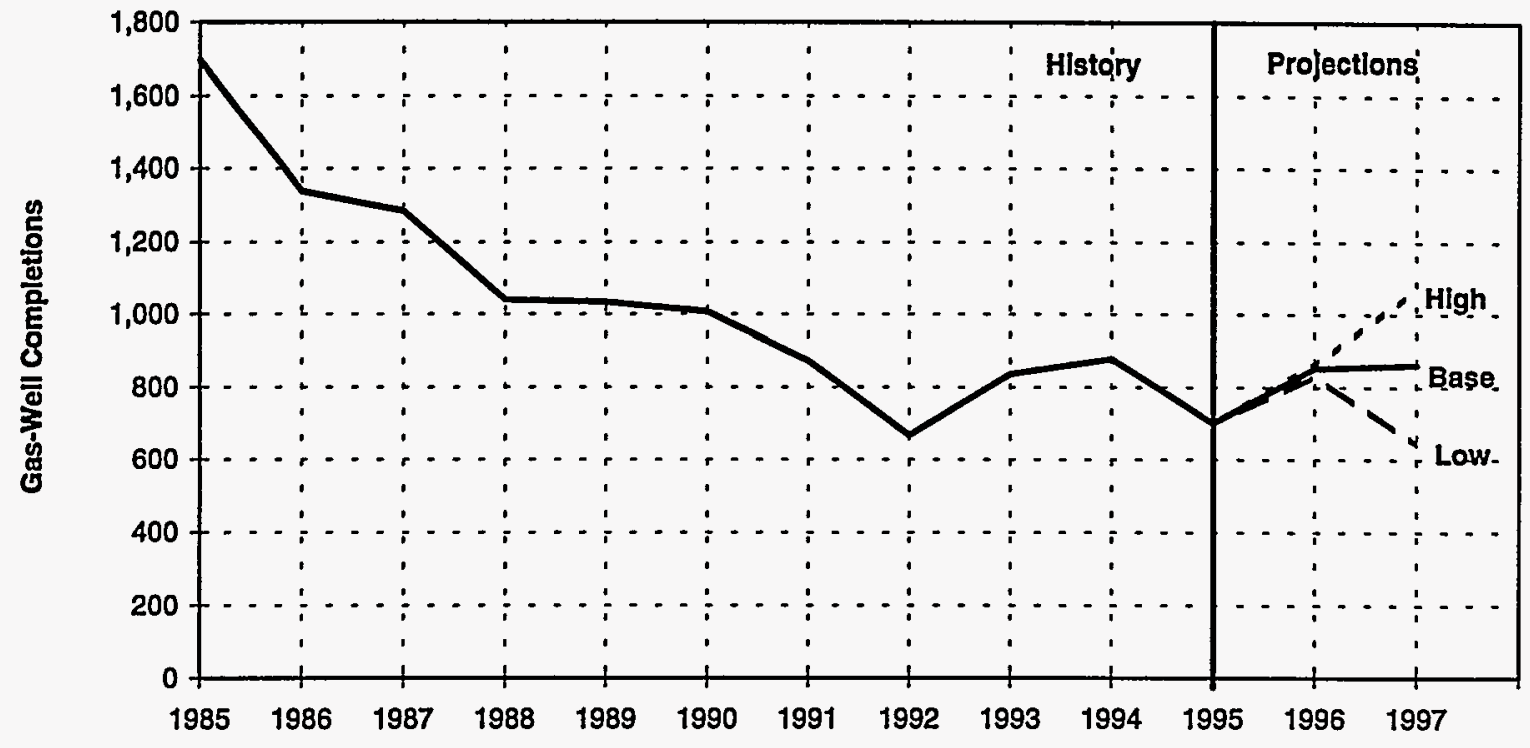

Note: The 1995 estimated history is based on Drilling Rig Model projections and Baker Hughes rig counts. Completions Include recompletions in new producing zones.

Sources: History: Energy Information Administration, Office of Oll and Gas; Dwight's Energydata, Inc. Projections: Model GASCAP94 C110196.

Figure 33. Percent of Total Wellhead Productive Capacity of Oklahoma Gas Wells by Well Age, 1985-1997 (Base Case)

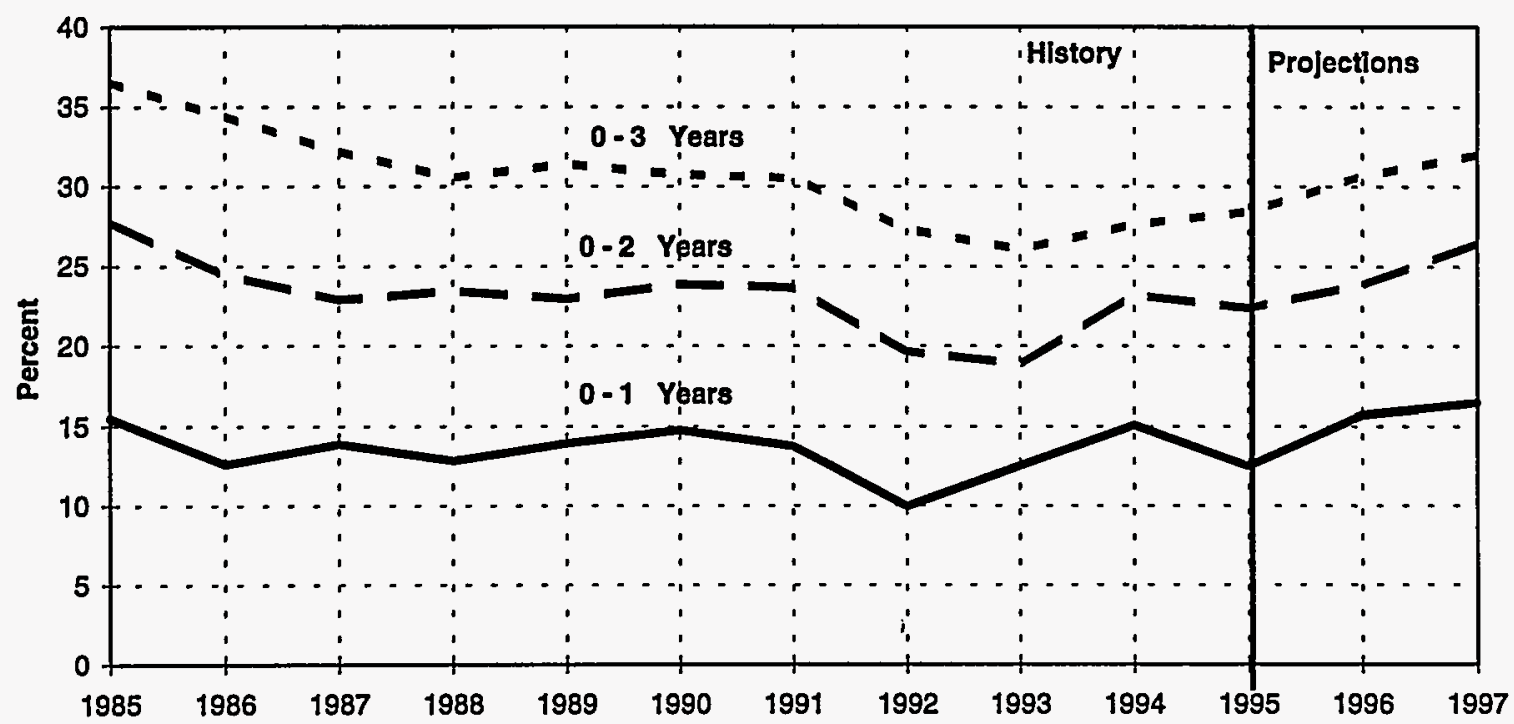

Sources: History: Energy Information Administration, Office of Oil and Gas; Dwight's Energydata, Inc. Projections: Model GASCAP94 C110196. 


\section{Southeast (Excluding Gulf of Mexico OCS)}

The Southeast area includes the States of Arkansas, Mississippi, and Alabama (excluding Gulf of Mexico OCS). Production is from highly permeable deep formations on the Gulf Coast, as well as from low permeability and relatively shallow formations in Arkansas, northern Mississippi, and northern Alabama.

Coalbed gas production in Alabama was 35 percent of the State's total dry gas production in 1990, 47 percent in 1991, 35 percent in 1992, 37 percent in 1993, and 28 percent in 1994. \{12\} Coalbed gas-well completions in Alabama were treated separately from conventional gas-well completions in this report. Coalbed gas capacity increased through 1995, then began a decline (Figure 35).

The following pages include Tables 17 and 18 and Figures 34 through 37 , which provide historical and projected production and productive capacity, gas-well completions added, and percent of capacity by well age.

Figure 34. Southeast (Excluding Gulf of Mexico OCS) Dry Gas Monthly Production Rate and Wellhead Productive Capacity, 1985-1997

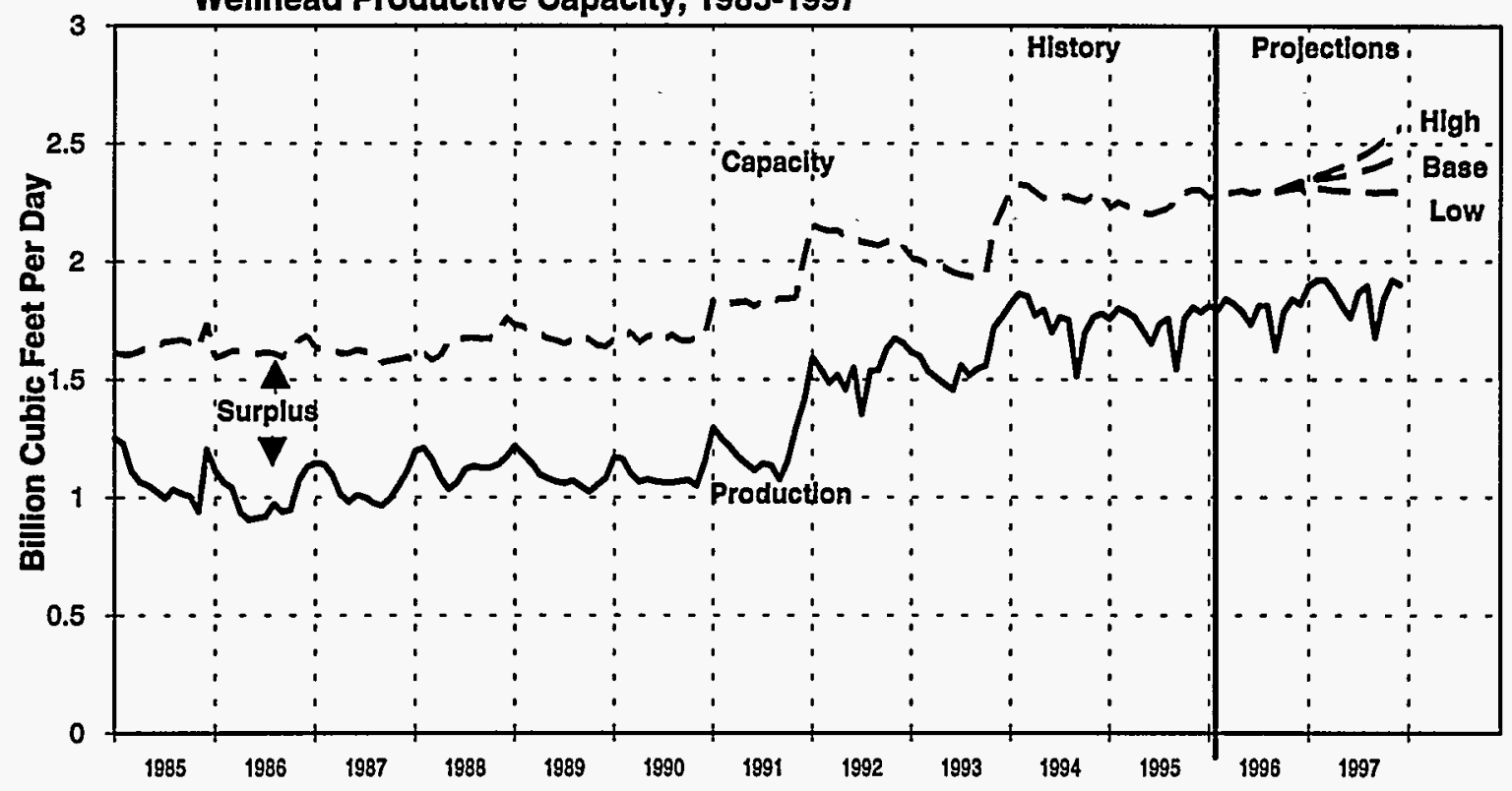

Note: Production projection plotted for base case only. The 1995 estimated history is based on Model GASCAP94 C1 10196 projections.

Sources: Production History: Energy Information Administration, Office of Oll and Gas; Dwight's Energydata, Inc.; and Model GASCAP94 C110198. Productive Capacity: Model GASCAP94 C110196. Production Prolections: Energy Information Administration, Short-Term Integrated Forecasting System, Fourth Quarter 1996, and Model GASCAP94 C110196. 
Table 17. Southeast (Excluding Gulf of Mexico OCS) Dry Gas Production and Wellhead Productive Capacity, 1985-1995 (Million Cubic Feet Per Day)

\begin{tabular}{|c|c|c|c|c|c|c|}
\hline \multirow[b]{2}{*}{ Month-Year } & \multirow[b]{2}{*}{$\begin{array}{c}\text { Dry } \\
\text { Production }\end{array}$} & \multicolumn{5}{|c|}{ Dry Gas Productive Capacity } \\
\hline & & $\begin{array}{c}\text { Gas-Well } \\
\text { Gas }\end{array}$ & $\begin{array}{c}\text { Oil-Well } \\
\text { Gas }\end{array}$ & $\begin{array}{l}\text { Total } \\
\text { Gas }\end{array}$ & $\begin{array}{c}\text { Total } \\
\text { Surplus }\end{array}$ & $\begin{array}{l}\text { Utilization } \\
\text { (percent) }\end{array}$ \\
\hline Jan-85 & 1,251 & 1,472 & 141 & 1,613 & 362 & 77.6 \\
\hline Jun-85 & 1,025 & 1,495 & 147 & 1,642 & 617 & 62.4 \\
\hline Dec-85 & 1,204 & 1,589 & 150 & 1,739 & 535 & 69.2 \\
\hline Jan-86 & 1,110 & 1,448 & 146 & 1,594 & 484 & 69.6 \\
\hline Jun-86 & 909 & 1,473 & 137 & 1,610 & 701 & 56.5 \\
\hline Dec-86 & 1,128 & 1,556 & 131 & 1,687 & 559 & 66.9 \\
\hline Jan-87 & 1,146 & 1,508 & 128 & 1,636 & 490 & 70.0 \\
\hline Jun-87 & 1,008 & 1,496 & 130 & 1,626 & 618 & 62.0 \\
\hline Dec-87 & 1,109 & 1,468 & 127 & 1,595 & 486 & 69.5 \\
\hline Jan-88 & 1,197 & 1,459 & 124 & 1,583 & 386 & 75.6 \\
\hline Jun-88 & 1,062 & 1,545 & 121 & 1,666 & 604 & 63.7 \\
\hline Dec-88 & 1,171 & 1,644 & 119 & 1,763 & 592 & 66.4 \\
\hline Jan-89 & 1,216 & 1,609 & 126 & 1,735 & 519 & 70.1 \\
\hline Jun-89 & 1,067 & 1,539 & 127 & 1,666 & 599 & 64.0 \\
\hline Dec-89 & 1,082 & 1,526 & 115 & 1,641 & 559 & 65.9 \\
\hline Jan-90 & 1,168 & 1,561 & 109 & 1,670 & 502 & 69.9 \\
\hline Jun-90 & 1,068 & 1,582 & 110 & 1,692 & 624 & 63.1 \\
\hline Dec-90 & 1,152 & 1,574 & 112 & 1,686 & 534 & 68.3 \\
\hline Jan-91 & 1,293 & 1,741 & 94 & 1,835 & 542 & 70.5 \\
\hline Jun-91 & 1,114 & 1,720 & 92 & 1,812 & 698 & 61.5 \\
\hline Dec-91 & 1,413 & 1,922 & 93 & 2,015 & 602 & 70.1 \\
\hline Jan-92 & 1,592 & 1,996 & 156 & 2,152 & 560 & 74.0 \\
\hline Jun-92 & 1,549 & 1,946 & 152 & 2,098 & 549 & 73.8 \\
\hline Dec-92 & 1,655 & 1,917 & 149 & 2,066 & 411 & 80.1 \\
\hline Jan-93 & 1,617 & 1,864 & 150 & 2,014 & 397 & 80.3 \\
\hline Jun-93 & 1,456 & 1,813 & 141 & 1,954 & 498 & 74.5 \\
\hline Dec-93 & 1,770 & 2,080 & 141 & 2,221 & 451 & 79.7 \\
\hline Jan-94 & 1,822 & 2,177 & 124 & 2,301 & 479 & 79.2 \\
\hline Jun-94 & 1,703 & 2,150 & 120 & 2,270 & 567 & 75.0 \\
\hline Dec-94 & 1,781 & 2,171 & 118 & 2,289 & 508 & 77.8 \\
\hline Jan-95' & 1,761 & 2,112 & 117 & 2,229 & 468 & 79.0 \\
\hline Jun-95" & 1,654 & 2,082 & 118 & 2,200 & 546 & 75.2 \\
\hline Dec-95 & 1,788 & 2,183 & 118 & 2,301 & 513 & 77.7 \\
\hline
\end{tabular}

"The 1995 estimated history is based on Model GASCAP94 C110196 projectlons and Baker Hughes rig counts.

Sources: Production History: Energy Information Administration, Office of Oll and Gas; Dwight's Energydata, Inc.; and Model GASCAP94 C110196. Productive Capacity: Model GASCAP94 C110196. 
Table 18. Southeast (Excluding Gulf of Mexico OCS) Dry Gas Production and Wellhead Productive Capacity Projections, 1996-1997 (Million Cubic Feet Per Day)

\begin{tabular}{|c|c|c|c|c|c|c|}
\hline \multirow[b]{2}{*}{ Month-Year } & \multirow[b]{2}{*}{$\begin{array}{c}\text { Dry } \\
\text { Production }\end{array}$} & \multicolumn{5}{|c|}{ Dry Gas Productive Capacity } \\
\hline & & $\begin{array}{c}\text { Gas-Well } \\
\text { Gas }\end{array}$ & $\begin{array}{c}\text { Oil-Well } \\
\text { Gas }\end{array}$ & $\begin{array}{c}\text { Total } \\
\text { Gas } \\
\end{array}$ & $\begin{array}{c}\text { Total } \\
\text { Surplus }\end{array}$ & $\begin{array}{l}\text { Utilizatlon } \\
\text { (percent) }\end{array}$ \\
\hline & \multicolumn{6}{|c|}{ Low Case Projection } \\
\hline Jan-96 & 1,815 & 2,150 & 119 & 2,269 & 454 & 80.0 \\
\hline Jun-96 & 1,737 & 2,169 & 120 & 2,289 & 552 & 75.9 \\
\hline Dec-96 & 1,821 & 2,196 & 116 & 2,312 & 491 & 78.8 \\
\hline Jan-97 & 1,897 & 2,168 & 115 & 2,283 & 386 & 83.1 \\
\hline Jun-97 & 1,765 & 2,186 & 112 & 2,298 & 533 & 76.8 \\
\hline \multirow[t]{2}{*}{ Dec-97 } & 1,933 & 2,185 & 109 & 2,294 & 361 & 84.3 \\
\hline & \multicolumn{6}{|c|}{ Base Case Projection } \\
\hline Jan-96 & 1,815 & 2,150 & 119 & 2,269 & 454 & 80.0 \\
\hline Jun-96 & 1,737 & 2,169 & 120 & 2,289 & 552 & 75.9 \\
\hline Dec-96 & 1,820 & 2,213 & 118 & 2,331 & 511 & 78.1 \\
\hline Jan-97 & 1,895 & 2,186 & 118 & 2,304 & 409 & 82.2 \\
\hline Jun-97 & 1,765 & 2,254 & 117 & 2,371 & 606 & 74.4 \\
\hline \multirow[t]{2}{*}{ Dec-97 } & 1,903 & 2,325 & 116 & 2,441 & 538 & 78.0 \\
\hline & \multicolumn{6}{|c|}{ High Case Projection } \\
\hline Jan-96 & 1,815 & 2,150 & 119 & 2,269 & 454 & 80.0 \\
\hline Jun-96 & 1,737 & 2,169 & 120 & 2,289 & 552 & 75.9 \\
\hline Dec-96 & 1,819 & 2,219 & 120 & 2,339 & 520 & 77.8 \\
\hline Jan-97 & 1,895 & 2,193 & 121 & 2,314 & 419 & 81.9 \\
\hline Jun-97 & 1,765 & 2,300 & 120 & 2,420 & 655 & 72.9 \\
\hline Dec-97 & 1,880 & 2,446 & 121 & 2,567 & 687 & 73.2 \\
\hline
\end{tabular}

Sources: Production Projections: Energy Information Administration, Short-Term IntegratedForecasting System, Fourth Quarter 1996, and Model GASCAP94 C110196. Productive Capacity Projections: Model GASCAP94 C110196. 
Figure 35. Southeast (Excluding Gulf of Mexico OCS) Dry Coalbed Gas Monthly Production Rate and Wellhead Productive Capacity, 1985-1997

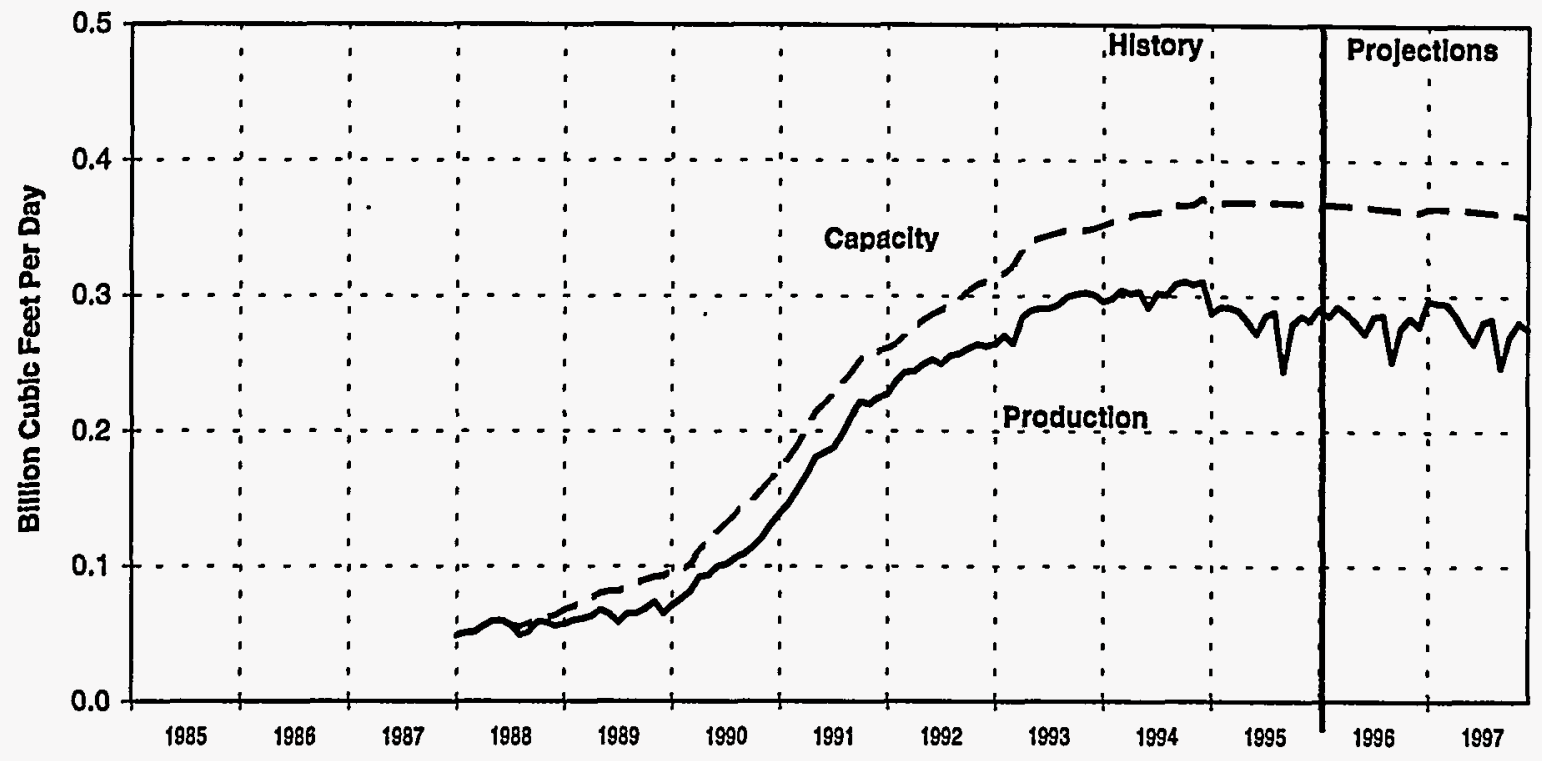

Note: Production projectlon plotted for base case only.

Sources: Production History: Energy Information Administration, Office of Oll and Gas; Dwight's Energydata, Inc.; and Model GASCAP94 C110196. Productlve Capacity: Model GASCAP94 C11016. Production Projectlons: Energy Informatlon Administration, Short-Term Integrated Forecasting System, Fourth Quarter 1996, and Model GASCAP94 C110196.

Figure 36. Southeast (Excluding Gulf of Mexico OCS) Gas-Well Completions Added During Year, 1985-1997

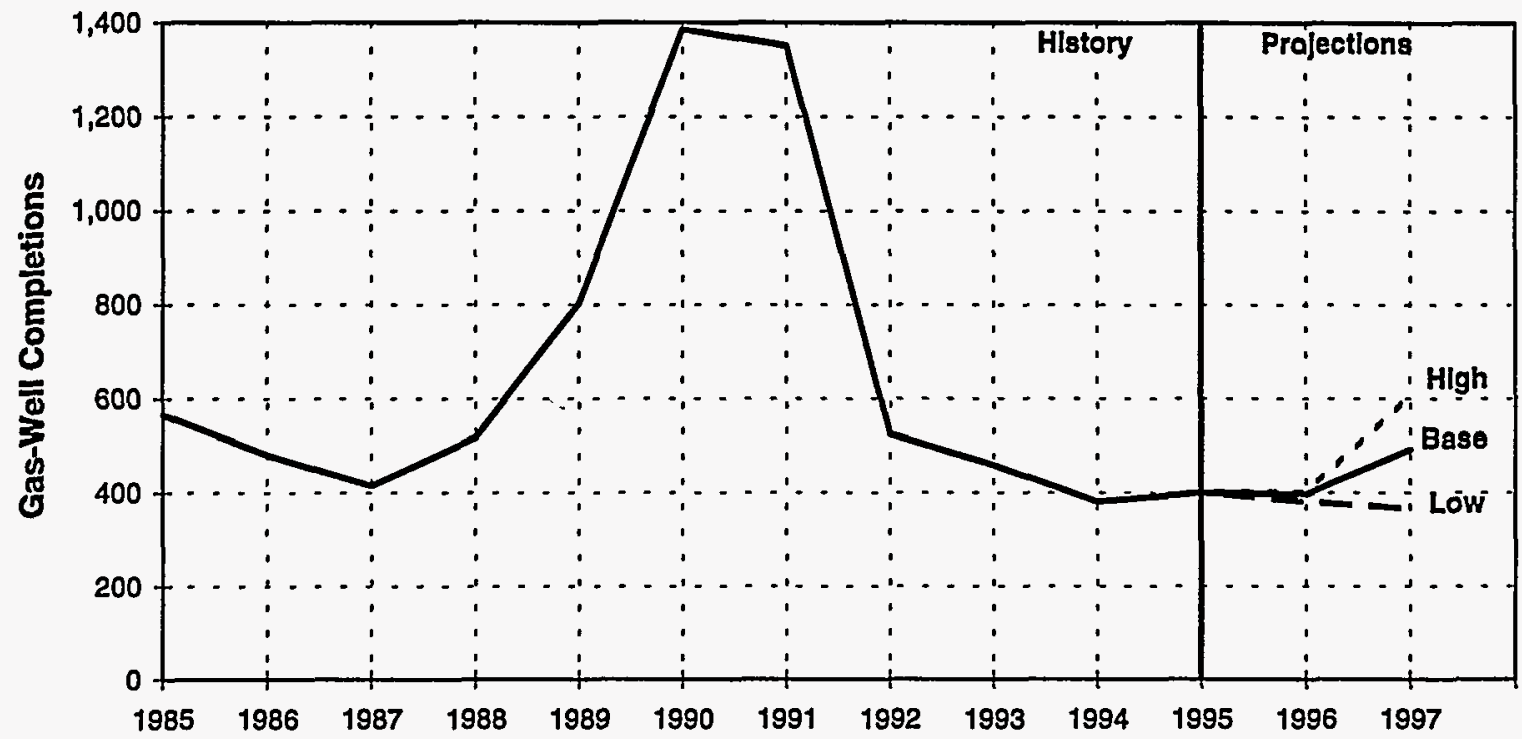

Note: The 1995 estimated history is based on Drilling Rig Model projections and Baker Hughes rig counts. Completions include recompletions in new producing zones.

Sources: HIstory: Energy Information Administration, Office of Oll and Gas; Dwight's Energydata, Inc. Projections: Model GASCAP94 C110196. 
Figure 37. Percent of Total Wellhead Productive Capacity of Southeast (Excluding Gulf of Mexico) Gas Wells by Well Age, 1985-1997 (Base Case)

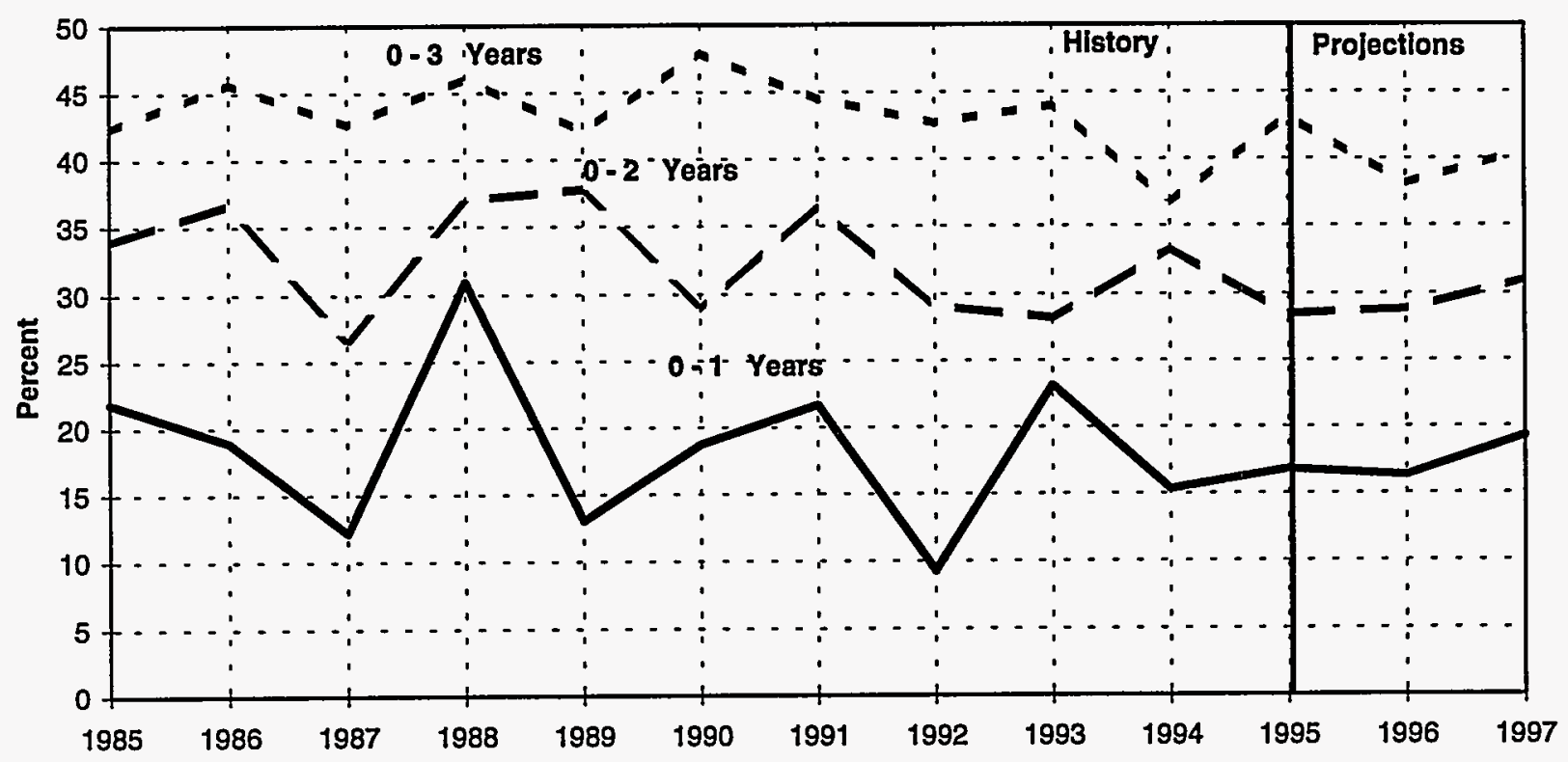

Sources: History: Energy Information Administration, Office of Oil and Gas; Dwight's Energydata, Inc. Projections: Model GASCAP94 C110196. 


\section{Rocky Mountains}

The Rocky Mountains area includes Colorado, Montana, North Dakota, Utah, and Wyoming. The area is diverse and geologically complex, with many low permeability formations.

Coalbed gas produced in Colorado was about 11 percent of the State's total dry gas produced in 1990, 17 percent in 1991, 26 percent in 1992, 32 percent in 1993, and 40 percent in 1994. (12) Coalbed gas-well completions in Colorado and Wyoming were treated separately from conventional gas-well completions in this report. Coalbed gas capacity has shown an increase in the last few years (Figure 39).

The following pages include Tables 19 and 20 and Figures 38 through 41, which provide historical and projected production and productive capacity, gas-well completions added, and percent of capacity by well age.

Figure 38. Rocky Mountains Dry Gas Monthly Production Rate and Wellhead Productive

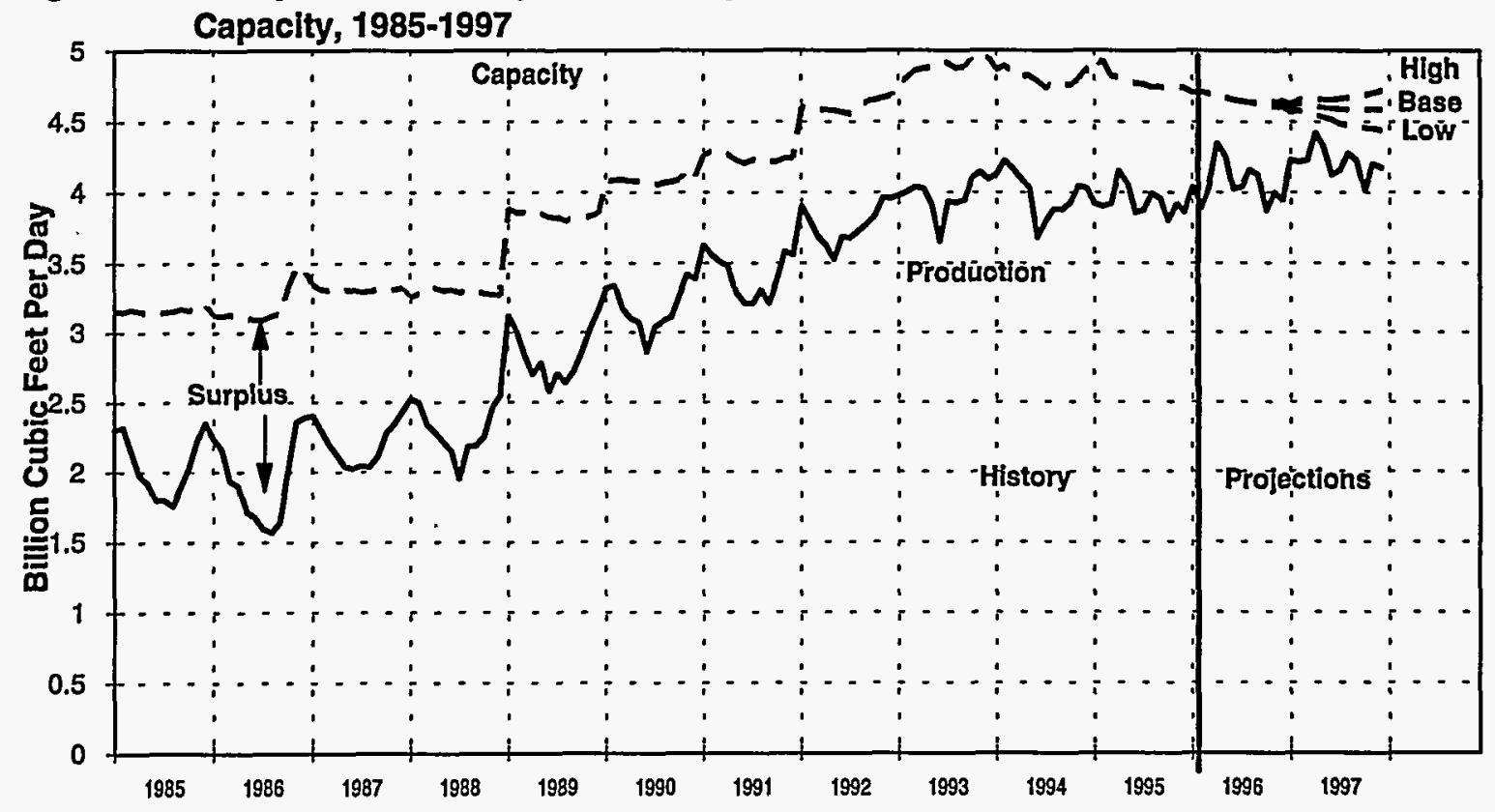

Note: Production projection plotted for base case only. The 1995 estimated hlstory is based on Model GASCAP94 C110196 projections.

Sources: Production History: Energy Information Administration, Office of Oil and Gas; Dwight's Energydata, Inc.; and Model GASCAP94 C110196. Productive Capacity: Model GASCAP94 C110196. Production Projections: Energy Information Administration, Short-Term Integrated Forecasting System, Fourth Quarter 1996, and Model GASCAP94 C110196. 
Table 19. Rocky Mountains Dry Gas Production and Wellhead Productive Capacity, 1985-1995 (Million Cubic Feet Per Day)

\begin{tabular}{|c|c|c|c|c|c|c|}
\hline \multirow[b]{2}{*}{ Month-Year } & \multirow[b]{2}{*}{$\begin{array}{c}\text { Dry } \\
\text { Production }\end{array}$} & \multicolumn{5}{|c|}{ Dry Gas Productive Capacity } \\
\hline & & $\begin{array}{c}\text { Gas-Well } \\
\text { Gas }\end{array}$ & $\begin{array}{c}\text { Oil-Well } \\
\text { Gas }\end{array}$ & $\begin{array}{c}\text { Total } \\
\text { Gas }\end{array}$ & $\begin{array}{c}\text { Total } \\
\text { Surplus } \\
\end{array}$ & $\begin{array}{l}\text { Utilization } \\
\text { (percent) }\end{array}$ \\
\hline Jan-85 & 2,306 & 2,520 & 634 & 3,154 & 848 & 73.1 \\
\hline Jun-85 & 1,804 & 2,508 & 636 & 3,144 & 1,340 & 57.4 \\
\hline Dec-85 & 2,352 & 2,597 & 609 & 3,206 & 854 & 73.4 \\
\hline Jan-86 & 2,240 & 2,475 & 650 & 3,125 & 885 & 71.7 \\
\hline Jun-86 & 1,671 & 2,488 & 600 & 3,088 & 1,417 & 54.1 \\
\hline Dec-86 & 2,389 & 2,910 & 562 & 3,472 & 1,083 & 68.8 \\
\hline Jan-87 & 2,402 & 2,570 & 785 & 3,355 & 953 & 71.6 \\
\hline Jun-87 & 2,025 & 2,545 & 761 & 3,306 & 1,281 & 61.3 \\
\hline Dec-87 & 2,437 & 2,561 & 763 & 3,324 & 887 & 73.3 \\
\hline Jan-88 & 2,523 & 2,457 & 802 & 3,259 & 736 & 77.4 \\
\hline Jun-88 & 2,147 & 2,508 & 804 & 3,312 & 1,165 & 64.8 \\
\hline Dec-88 & 2,552 & 2,518 & 754 & 3,272 & 720 & 78.0 \\
\hline Jan-89 & 3,117 & 2,973 & 909 & 3,882 & 765 & 80.3 \\
\hline Jun-89 & 2,580 & 2,952 & 873 & 3,825 & 1,245 & 67.5 \\
\hline Dec-89 & 3,155 & 2,990 & 861 & 3,851 & 696 & 81.9 \\
\hline Jan-90 & 3,318 & 3,011 & 1,061 & 4,072 & 754 & 81.5 \\
\hline Jun-90 & 2,861 & 3,022 & 1,045 & 4,067 & 1,206 & 70.3 \\
\hline Dec-90 & 3,390 & 3,097 & 1,015 & 4,112 & 722 & 82.4 \\
\hline Jan-91 & 3,626 & 3,157 & 1,102 & 4,259 & 633 & 85.1 \\
\hline Jun-91 & 3,207 & 3,125 & 1,077 & 4,202 & 995 & 76.3 \\
\hline Dec-91 & 3,559 & 3,191 & 1,048 & 4,239 & 680 & 84.0 \\
\hline Jan-92 & 3,899 & 3,519 & 1,080 & 4,599 & 700 & 84.8 \\
\hline Jun-92 & 3,685 & 3,516 & 1,051 & 4,567 & 882 & 80.7 \\
\hline Dec-92 & 3,956 & 3,675 & 1,009 & 4,684 & 728 & 84.5 \\
\hline Jan-93 & 3,977 & 4,006 & 765 & 4,771 & 794 & 83.4 \\
\hline Jun-93 & 3,655 & 4,142 & 770 & 4,912 & 1,257 & 74.4 \\
\hline Dec-93 & 4,091 & 4,212 & 736 & 4,948 & 857 & 82.7 \\
\hline Jan-94 & 4,123 & 4,219 & 646 & 4,865 & 742 & 84.7 \\
\hline Jun-94 & 3,680 & 4,154 & 634 & 4,788 & 1,108 & 76.9 \\
\hline Dec-94 & 4,024 & 4,254 & 617 & 4,871 & 847 & 82.6 \\
\hline Jan-95 & 3,921 & 4,204 & 629 & 4,833 & 912 & 81.1 \\
\hline Jun-95 & 3,858 & 4,163 & 609 & 4,772 & 914 & 80.8 \\
\hline Dec-95 & 3,862 & 4,120 & 615 & 4,735 & 873 & 81.6 \\
\hline
\end{tabular}

\footnotetext{
"The 1995 estimated history is based on Model GASCAP94 C110196 projections and Baker Hughes rig counts.

Sources: Production History: Energy Information Administration, Office of Oil and Gas; Dwight's Energydata, Inc.; and Model GASCAP94 C110196. Productive Capacity: Model GASCAP94 C110196.
} 
Table 20. Rocky Mountains Dry Gas Production and Wellhead Productive Capacity Projections, 1996-1997 (Million Cubic Feet Per Day)

\begin{tabular}{|c|c|c|c|c|c|c|}
\hline \multirow[b]{2}{*}{ Month-Year } & \multirow[b]{2}{*}{$\begin{array}{c}\text { Dry } \\
\text { Production }\end{array}$} & \multicolumn{5}{|c|}{ Dry Gas Productive Capacity } \\
\hline & & $\begin{array}{c}\text { Gas-Well } \\
\text { Gas }\end{array}$ & $\begin{array}{c}\text { Oll-Well } \\
\text { Gas }\end{array}$ & $\begin{array}{l}\text { Total } \\
\text { Gas } \\
\end{array}$ & $\begin{array}{c}\text { Total } \\
\text { Surplus } \\
\end{array}$ & $\begin{array}{l}\text { Utilization } \\
\text { (percent) }\end{array}$ \\
\hline & \multicolumn{6}{|c|}{ Low Case Projection } \\
\hline Jan-96 & 4,038 & 4,086 & 622 & 4,708 & 670 & 85.8 \\
\hline Jun-96 & 4,027 & 4,031 & 624 & 4,655 & 628 & 86.5 \\
\hline Dec-96 & 3,946 & 4,001 & 603 & 4,604 & 658 & 85.7 \\
\hline Jan-97 & 4,231 & 3,973 & 596 & 4,569 & 338 & 92.6 \\
\hline Jun-97 & 4,124 & 3,934 & 581 & 4,515 & 391 & 91.3 \\
\hline \multirow[t]{2}{*}{ Dec-97 } & 4,240 & 3,880 & 562 & 4,442 & 202 & 95.5 \\
\hline & \multicolumn{6}{|c|}{ Base Case Projection } \\
\hline Jan-96 & 4,038 & 4,086 & 622 & 4,708 & 670 & 85.8 \\
\hline Jun-96 & 4,027 & 4,031 & 624 & 4,655 & 628 & 86.5 \\
\hline Dec-96 & 3,944 & 4,015 & 615 & 4,630 & 686 & 85.2 \\
\hline Jan-97 & 4,226 & 3,988 & 613 & 4,601 & 375 & 91.8 \\
\hline Jun-97 & 4,124 & 3,991 & 604 & 4,595 & 471 & 89.7 \\
\hline \multirow[t]{2}{*}{ Dec-97 } & 4,175 & 3,994 & 596 & 4,590 & 415 & 91.0 \\
\hline & \multicolumn{6}{|c|}{ High Case Projection } \\
\hline Jan-96 & 4,038 & 4,086 & 622 & 4,708 & 670 & 85.8 \\
\hline Jun-96 & 4,027 & 4,031 & 624 & 4,655 & 628 & 86.5 \\
\hline Dec-96 & 3,942 & 4,020 & 625 & 4,645 & 703 & 84.9 \\
\hline Jan-97 & 4,226 & 3,995 & 629 & 4,624 & 398 & 91.4 \\
\hline Jun-97 & 4,124 & 4,032 & 624 & 4,656 & 532 & 88.6 \\
\hline Dec-97 & 4,123 & 4,097 & 623 & 4,720 & 597 & 87.4 \\
\hline
\end{tabular}

Sources: Production Projections: Energy Information Administration, Short-Term Integrated Forecasting System, Fourth Quarter 1996, and Model GASCAP94 C110196. Productive Capacity Projections: Model GASCAP94 C110196. 
Figure 39. Rocky Mountains Dry Coalbed Gas Monthly Production Rate and Wellhead Productive Capacity, 1985-1997

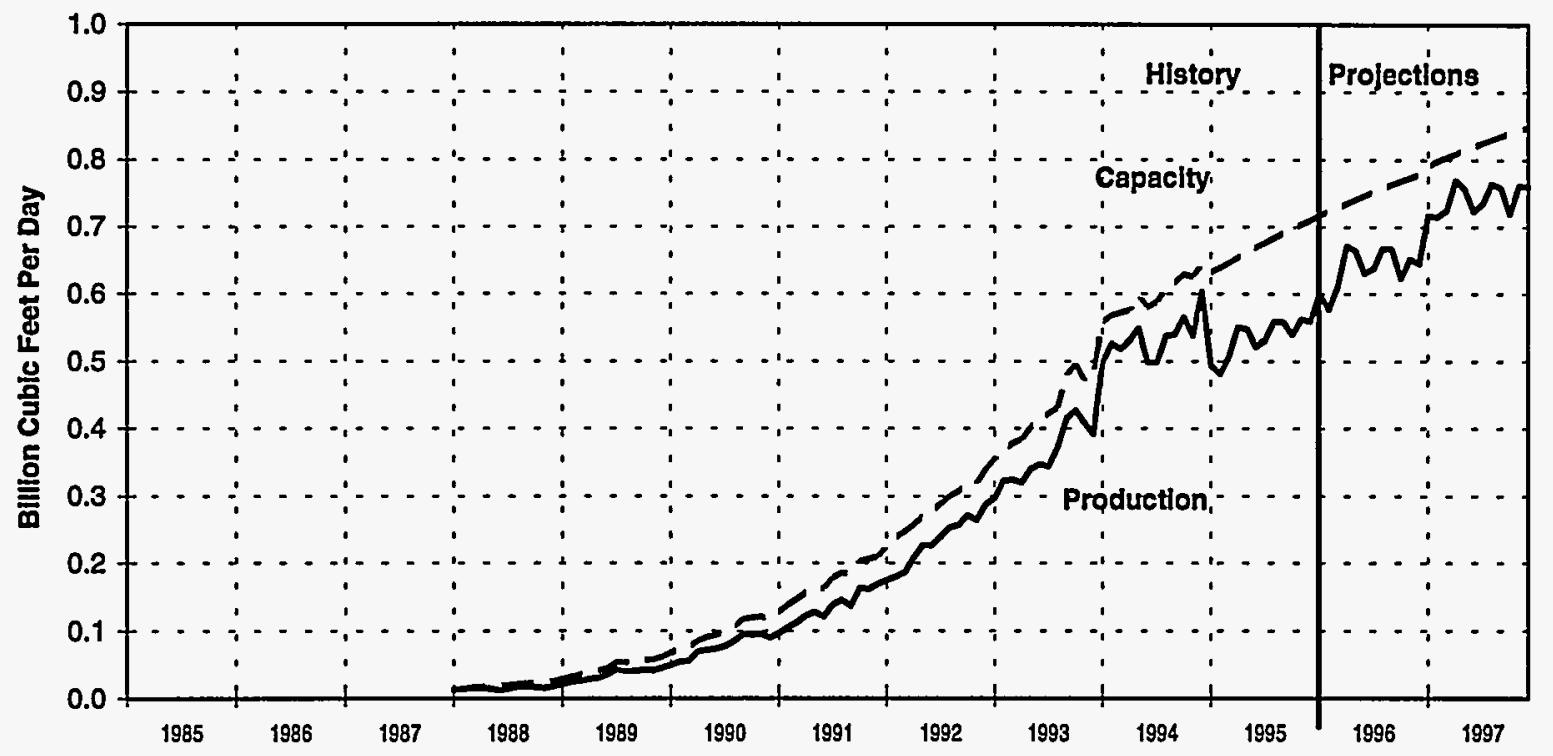

Note: Production projection plotted for base case only.

Sources: Production History: Energy Information Administration, Office of Oil and Gas; Dwight's Energydata, Inc.; and Model GASCAP94 C110196. Productive Capacity: Model GASCAP94 C11016. Production Projections: Energy Information Administration, Short-Term Integrated Forecasting System, Fourth Quarter 1996, and Model GASCAP94 C110196.

Figure 40. Rocky Mountains Gas-Well Completions Added During Year, 1985-1997

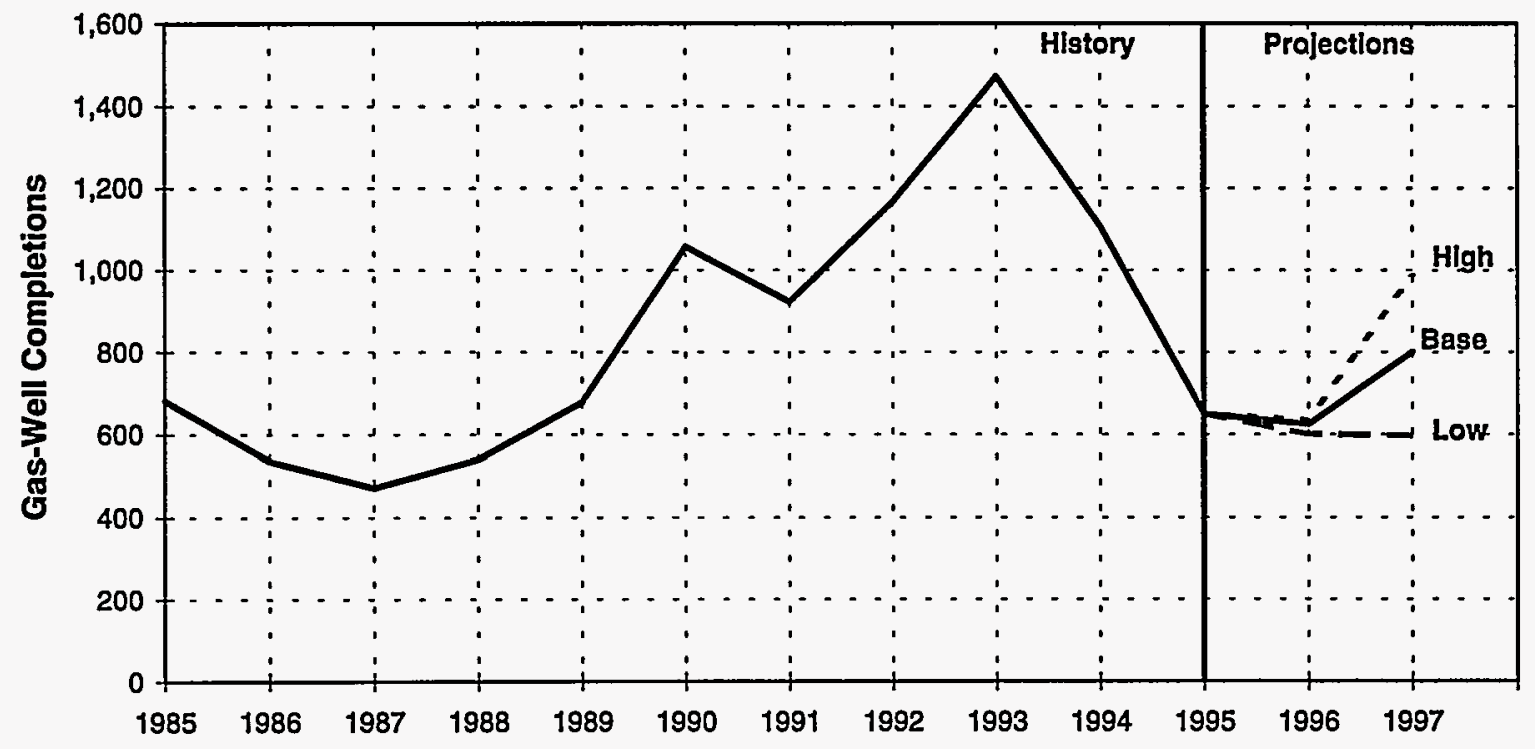

Note: The 1995 estimated history is based on Drilling Rig Model projectlons and Baker Hughes rig counts. Completlons include recompletions in new producing zones.

Sources: History: Energy Information Administration, Offlce of Oll and Gas; Dwight's Energydata, Inc. Projections: Model GASCAP94 C110196. 
Figure 41. Percent of Total Wellhead Productive Capacity of Rocky Mountains Gas Wells by Well Age, 1985-1997 (Base Case)

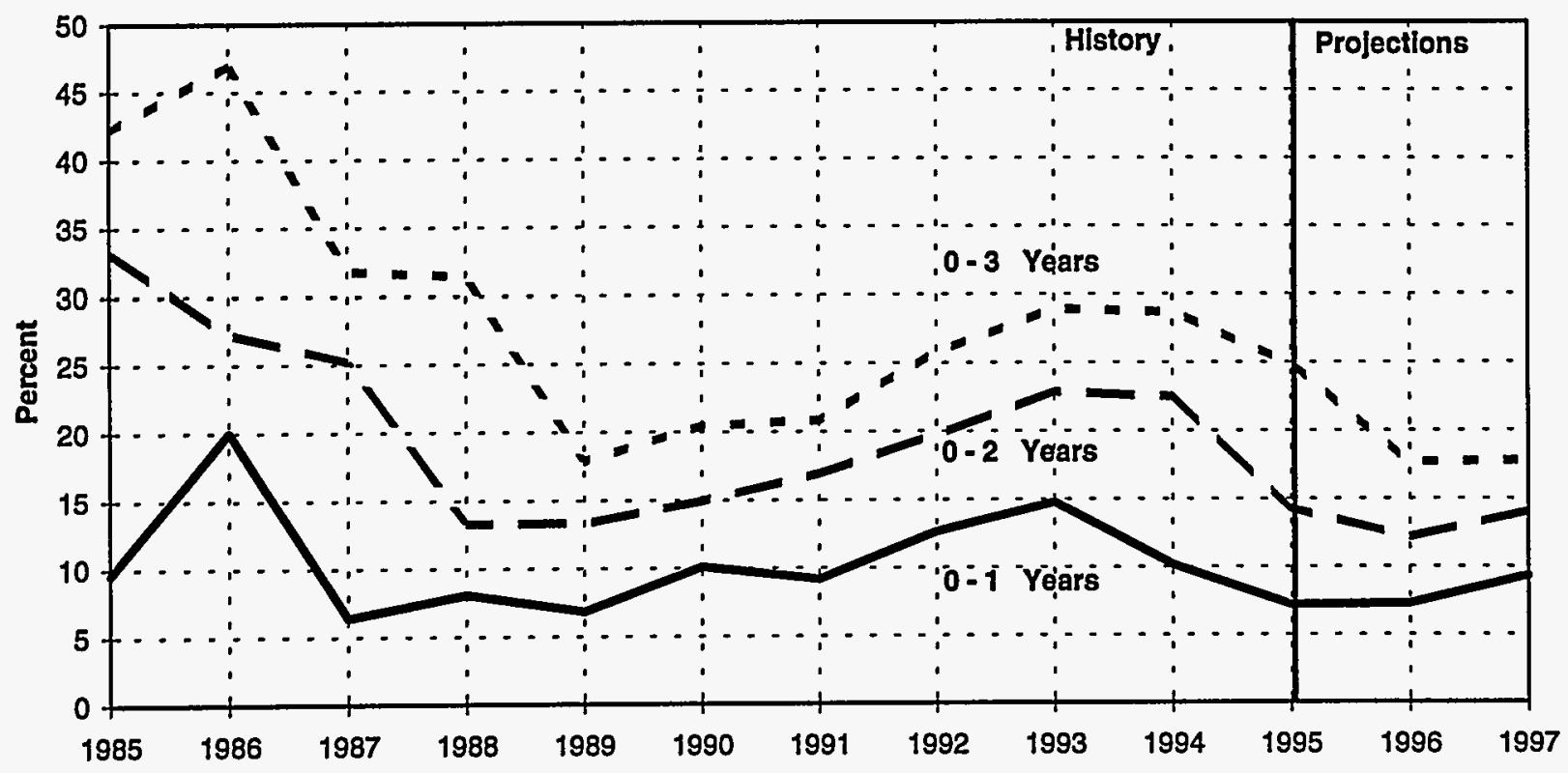

Sources: History: Energy Information Administration, Office of Oil and Gas; Dwight's Energydata, Inc. Projections: Model GASCAP94 C110196. 


\section{Eighteen States}

The remaining producing 18 States were considered as one group. The 18 States are:
- Arizona
- Michigan
- Florida
- Missouri
- Illinois
- Nebraska
- Indiana
- Nevada
- Kentucky
- New York
- Maryland

- Oregon

- Pennsylvania

- South Dakota

- Tennessee

- Virginia

- West Virginia.
Data are limited for this group of States, and only 3 of the 18 States are included in Dwight's: Nebraska, Oregon, and South Dakota. Production data are available from EIA for each of the 18 States but not by well completion. The 18 States are:

The following pages include Tables 21 and 22 and Figures 42 and 43 , which provide historical and projected production, productive capacity, and gas-well completions added.

Figure 42. Eighteen States Dry Gas Monthly Production Rate and Wellhead Productive

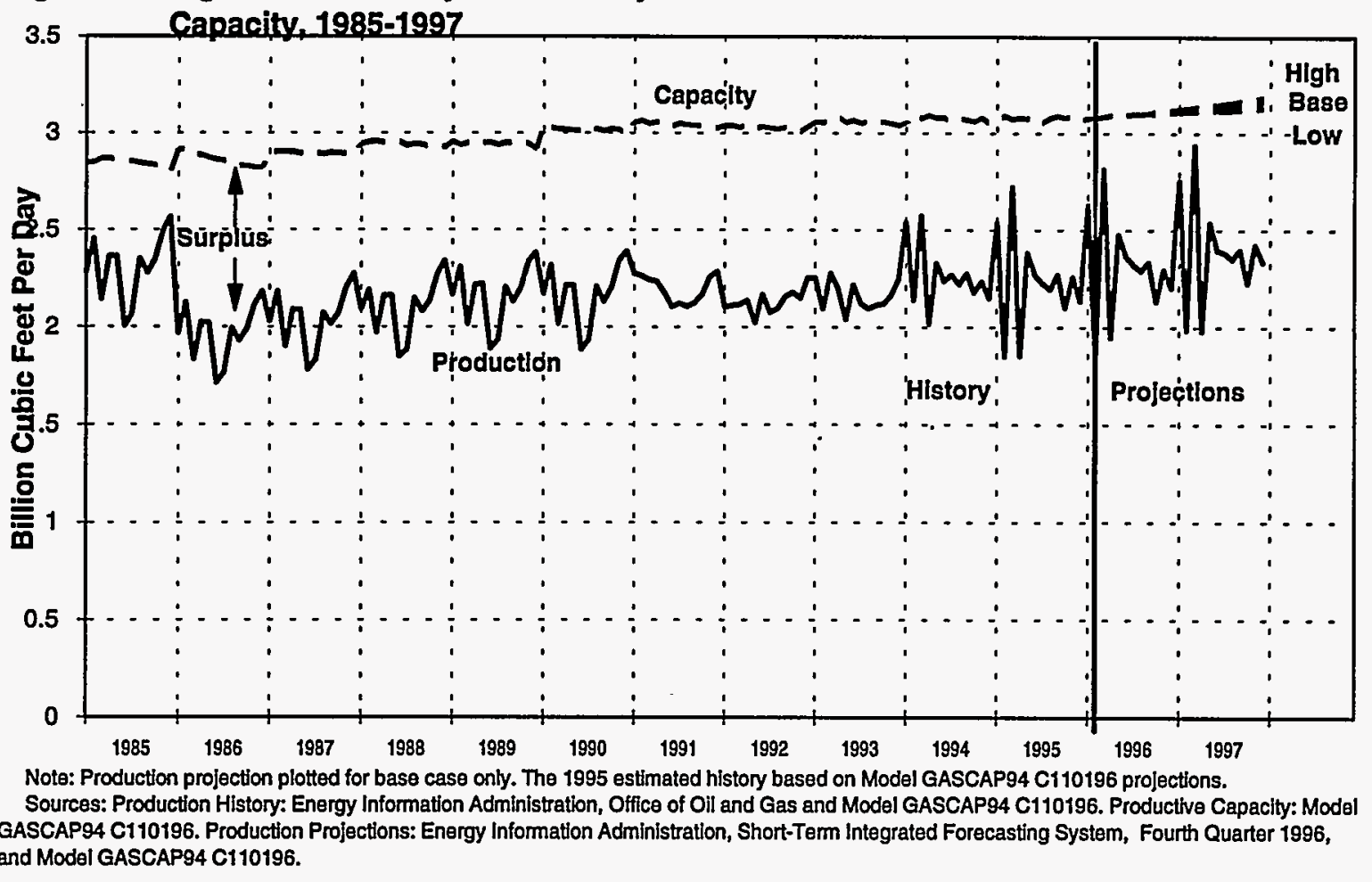


Table 21. Eighteen States Dry Gas Production and Wellhead Productive Capacity, 1985-1995 (Million Cubic Feet Per Day)

\begin{tabular}{|c|c|c|c|c|c|c|}
\hline \multirow[b]{2}{*}{ Month-Year } & \multirow[b]{2}{*}{$\begin{array}{c}\text { Dry } \\
\text { Production }\end{array}$} & \multicolumn{5}{|c|}{ Dry Gas Productive Capacity } \\
\hline & & $\begin{array}{c}\text { Gas-Well } \\
\text { Gas }\end{array}$ & $\begin{array}{c}\text { Oil-Well } \\
\text { Gas }\end{array}$ & $\begin{array}{c}\text { Total } \\
\text { Gas }\end{array}$ & $\begin{array}{c}\text { Total } \\
\text { Surplus }\end{array}$ & $\begin{array}{l}\text { Utilization } \\
\text { (percent) }\end{array}$ \\
\hline Jan-85 & 2,281 & 2,642 & 203 & 2,845 & 564 & 80.2 \\
\hline Jun-85 & 2,007 & 2,637 & 216 & 2,853 & 846 & 70.3 \\
\hline Dec-85 & 2,565 & 2,592 & 208 & 2,800 & 235 & 91.6 \\
\hline Jan-86 & 1,970 & 2,700 & 213 & 2,913 & 943 & 67.6 \\
\hline Jun-86 & 1,716 & 2,662 & 201 & 2,863 & 1,147 & 59.9 \\
\hline Dec-86 & 2,182 & 2,631 & 189 & 2,820 & 638 & 77.4 \\
\hline Jan-87 & 2,029 & 2,680 & 218 & 2,898 & 869 & 70.0 \\
\hline Jun-87 & 1,781 & 2,677 & 221 & 2,898 & 1,117 & 61.5 \\
\hline Dec-87 & 2,272 & 2,675 & 219 & 2,894 & 622 & 78.5 \\
\hline Jan-88 & 2,095 & 2,729 & 214 & 2,943 & 848 & 71.2 \\
\hline Jun-88 & 1,848 & 2,724 & 227 & 2,951 & 1,103 & 62.6 \\
\hline Dec-88 & 2,341 & 2,722 & 207 & 2,929 & 588 & 79.9 \\
\hline Jan-89 & 2,166 & 2,717 & 237 & 2,954 & 788 & 73.3 \\
\hline Jun-89 & 1,890 & 2,721 & 228 & 2,949 & 1,059 & 64.1 \\
\hline Dec-89 & 2,382 & 2,725 & 194 & 2,919 & 537 & 81.6 \\
\hline Jan-90 & 2,173 & 2,772 & 264 & 3,036 & 863 & 71.6 \\
\hline Jun-90 & 1,883 & 2,770 & 239 & 3,009 & 1,126 & 62.6 \\
\hline Dec-90 & 2,390 & 2,770 & 226 & 2,996 & 606 & 79.8 \\
\hline Jan-91 & 2,275 & 2,800 & 253 & 3,053 & 778 & 74.5 \\
\hline Jun-91 & 2,105 & 2,795 & 239 & 3,034 & 929 & 69.4 \\
\hline Dec-91 & 2,285 & 2,781 & 244 & 3,025 & 740 & 75.5 \\
\hline Jan-92 & 2,104 & 2,781 & 255 & 3,036 & 932 & 69.3 \\
\hline Jun-92 & 2,166 & 2,772 & 260 & 3,032 & 866 & 71.4 \\
\hline Dec-92 & 2,253 & 2,776 & 257 & 3,033 & 780 & 74.3 \\
\hline Jan-93 & 2,253 & 2,790 & 266 & 3,056 & 803 & 73.7 \\
\hline Jun-93 & 2,217 & 2,797 & 269 & 3,066 & 849 & 72.3 \\
\hline Dec-93 & 2,245 & 2,787 & 252 & 3,039 & 794 & 73.9 \\
\hline Jan-94 & 2,541 & 2,791 & 262 & 3,053 & 512 & 83.2 \\
\hline Jun-94 & 2,238 & 2,779 & 301 & 3,080 & 842 & 72.7 \\
\hline Dec-94 & 2,153 & 2,778 & 276 & 3,054 & 901 & 70.5 \\
\hline Jan-95 & 2,537 & 2,783 & 287 & 3,070 & 533 & 82.6 \\
\hline Jun-95 & 2,270 & 2,799 & 286 & 3,085 & 815 & 73.6 \\
\hline Dec-95 & 2,136 & 2,825 & 244 & 3,069 & 933 & 69.6 \\
\hline
\end{tabular}

"The 1995 estimated history is based on Model GASCAP94 C110196 projections and Baker Hughes rig counts.

Sources: Production History: Energy Information Administration, Office of Oil and Gas and Model

GASCAP94 C110196. Productive Capacity: Model GASCAP94 C110196. 
Table 22. Eighteen States Dry Gas Production and Wellhead Productive Capacity Projections, 1996-1997 (Million Cubic Feet Per Day)

\begin{tabular}{|c|c|c|c|c|c|c|}
\hline \multirow[b]{2}{*}{ Month-Year } & \multirow[b]{2}{*}{$\begin{array}{c}\text { Dry } \\
\text { Production }\end{array}$} & \multicolumn{5}{|c|}{ Dry Gas Productive Capacity } \\
\hline & & $\begin{array}{c}\text { Gas-Well } \\
\text { Gas }\end{array}$ & $\begin{array}{c}\text { Oil-Well } \\
\text { Gas }\end{array}$ & $\begin{array}{c}\text { Total } \\
\text { Gas }\end{array}$ & $\begin{array}{c}\text { Total } \\
\text { Surplus }\end{array}$ & $\begin{array}{l}\text { Utilization } \\
\text { (percent) }\end{array}$ \\
\hline & \multicolumn{6}{|c|}{ Low Case Projection } \\
\hline Jan-96 & 2,630 & 2,829 & 247 & 3,076 & 446 & 85.5 \\
\hline Jun-96 & 2,366 & 2,847 & 246 & 3,093 & 727 & 76.5 \\
\hline Dec-96 & 2,206 & 2,872 & 236 & 3,108 & 902 & 71.0 \\
\hline Jan-97 & 2,756 & 2,876 & 233 & 3,109 & 353 & 88.6 \\
\hline Jun-97 & 2,398 & 2,893 & 226 & 3,119 & 721 & 76.9 \\
\hline \multirow[t]{2}{*}{ Dec-97 } & 2,371 & 2,914 & 217 & 3,131 & 760 & 75.7 \\
\hline & \multicolumn{6}{|c|}{ Base Case Projection } \\
\hline Jan-96 & 2,630 & 2,829 & 247 & 3,076 & 446 & 85.5 \\
\hline Jun-96 & 2,366 & 2,847 & 246 & 3,093 & 727 & 76.5 \\
\hline Dec-96 & 2,205 & 2,872 & 241 & 3,113 & 908 & 70.8 \\
\hline Jan-97 & 2,754 & 2,877 & 240 & 3,117 & 363 & 88.4 \\
\hline Jun-97 & 2,398 & 2,900 & 235 & 3,135 & 737 & 76.5 \\
\hline \multirow[t]{2}{*}{ Dec-97 } & 2,335 & 2,930 & 230 & 3,160 & 825 & 73.9 \\
\hline & \multicolumn{6}{|c|}{ High Case Projection } \\
\hline Jan-96 & 2,630 & 2,829 & 247 & 3,076 & 446 & 85.5 \\
\hline Jun-96 & 2,366 & 2,847 & 246 & 3,093 & 727 & 76.5 \\
\hline Dec-96 & 2,204 & 2,873 & 245 & 3,118 & 914 & 70.7 \\
\hline Jan-97 & 2,754 & 2,878 & 246 & 3,124 & 370 & 88.2 \\
\hline Jun-97 & 2,398 & 2,905 & 242 & 3,147 & 749 & 76.2 \\
\hline Dec-97 & 2,306 & 2,944 & 240 & 3,184 & 878 & 72.4 \\
\hline
\end{tabular}

Sources: Production Projections: Energy Information Administration, Short-Term Integrated Forecasting System, Fourth Quarter 1996, and Model GASCAP94 C110196. Productive Capacity Projections: Model GASCAP94 C110196. 
Figure 43. Eighteen States Gas-Well Completions Added During Year, 1985-1997

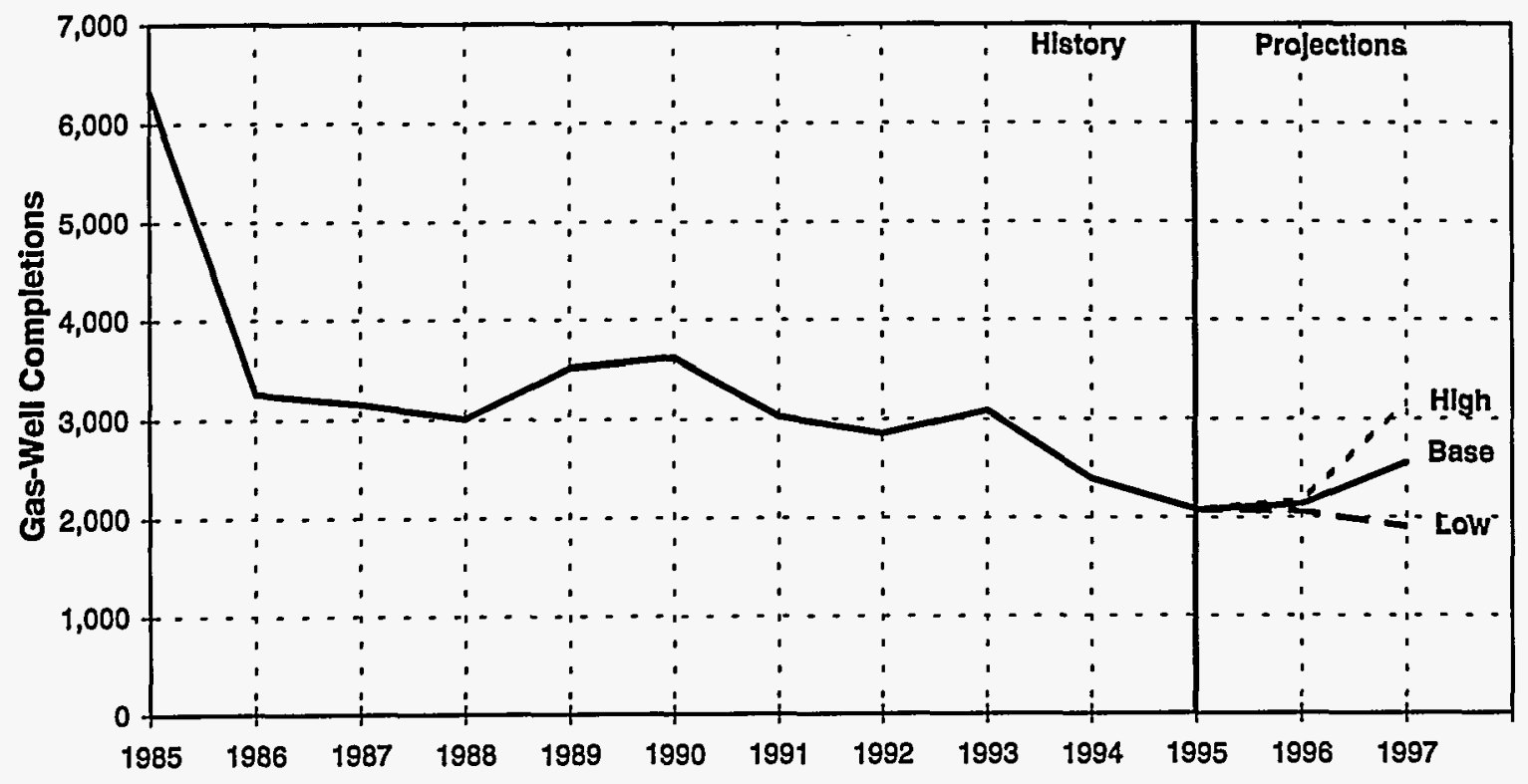

Note: The 1995 estimated history is based on Drilling Rig Model projections and Baker Hughes rig counts. Completions Include recompletions In new producing zones.

Sources: History: Energy Information Administration, Office of Oil and Gas. Estimates of gas-well completions based on API well completlon data. Projections: Model GASCAP94 C110196. 


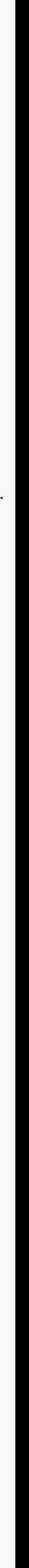




\section{References}

1. Energy Information Administration. Natural Gas Productive Capacity for the Lower 48 States 1980 through 1991. DOE/EIA-0542. Washington, DC, January 24, 1991.

2. Energy Information Administration. Natural Gas Productive Capacity for the Lower 48 States 1982 through 1993. DOE/EIA-0542. Washington, DC, March 10, 1993.

3. Energy Information Administration. Natural Gas Productive Capacity for the Lower 48 States 1980 through 1995. DOE/EIA-0542. Washington, DC, July 14, 1994.

4 Energy Information Administration. Natural Gas Productive Capacity for the Lower 48 States 1984 through 1996. DOE/EIA-0542. Washington, DC, February 9, 1996.

5. Energy Information Administration. Gas Deliverability and Flow Capacity of Surveillance Gas Fields in Texas Railroad Commission District 8. DOE/EIA0342. Washington, DC, April 1982.

6. Energy Information Administration. Gas Deliverability and Flow Capacity of Surveillance Gas Fields in Texas. DOE/EIA-0342(82). Washington, DC, October 1982.

7. Energy Information Administration. Gas Deliverability and Flow Capacity of Surveillance Gas Fields in Kansas, New Mexico, and Arkansas. DOE/EIA0416(83). Washington, DC, September 1983.

8. Energy Information Administration. Gas Deliverability and Flow Capacity of Surveillance Fields in Louisiana and Texas Federal Offshore Areas. DOE/EIA-0471. Washington, DC, January 23, 1986.

9. Energy Information Administration. Gas Deliverability and Flow Capacity of Surveillance Fields in Louisiana. DOE/EIA-0506. Washington, DC, December 2, 1987.

10. Rawlins, E.L., and Schellhardt, M.A. Back-Pressure Data On Natural Gas Wells and Their Application to Production Practices. U.S. Bureau of Mines Monograph 7, 1936.
11. Energy Information Administration. Short-Term Integrated Forecasting System, Fourth Quarter 1996.

12. Energy Information Administration. U.S. Crude Oil, Natural Gas, and Natural Gas Liquids Reserves Annual Report. DOE/EIA-0216. Washington, DC, 1991, 1992, 1993, and 1994.

13. Energy Information Administration. Natural Gas Annual. DOE/EIA-0131. Washington, DC, 1985 through 1994.

14. National Petroleum Council. The Potential for Natural Gas in the United States. Washington, DC, December 1992.

15. Energy Information Administration, EIAGIS-SD Geographic Information System, Underground Natural Gas Storage Database, based on data from the EIA Form-191 Underground Gas Storage Report, October 1996.

16 Energy Information Administration. Natural Gas Monthly. DOE/EIA-0130. Washington, DC, January 1984 Through December 1995.

17. Natural Gas Supply Association. Natural Gas Supply Association Survey: Natural Gas Field Deliveries \& Productive Capacity as of January 1, 1995. (Washington, DC, September 1995.

18. Energy Information Administration. Wellhead Gas Productive Capacity Model Documentation. DOE/EIA-M052. Washington, DC, March 1995.

19. Arps, J.J. Estimation of Primary Oil Reserves. Transactions of the American Institute of Mining, Metallurgical, and Petroleum Engineers. Volume 207. Dallas, TX 1956.

20. Cutler, W.W., Jr. Estimation of Underground Oil Reserves by Well Production Curves. U.S. Bureau of Mines Bull. 228, 1924.

21. Energy Information Administration. Petroleum Supply Annual. DOE/EIA-0340. Washington, DC, 1984 through 1994. 

Appendix A

Methodology

, 


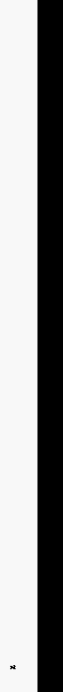




\section{Methodology}

This appendix generally describes the methodology used to estimate the gas productive capacity of conventional and coalbed gas wells and oil wells for each State or area. For more detail, see Appendix B or the Wellhead Gas Productive Capacity (GASCAP) Model Documentation. $\{18\}$ Lack of back-pressure test data and gas-in-place estimates by reservoir for a sizeable portion of the lower 48 States precluded doing conventional kinds of gas-well productive capacity studies that have been done in the past for specific States and areas. Because only production data were available for the lower 48 States, another technique had to be used. The lower 48 States were divided into States and multi-States for which production data by well is listed by Dwight's EnergyData, Inc. (Dwight's). The Gulf of Mexico Outer Continental Shelf (OCS), and each of six States (Texas, Louisiana, California, Kansas, New Mexico, and Oklahoma) were studied individually. Five States were grouped together as the Rocky Mountains area: Colorado, Montana, North Dakota, Utah, and Wyoming. A Southeast area consisted of Alabama, Arkansas, and Mississippi. An additional 18 States were studied as a group by using aggregate EIA monthly production data and API drilling statistics. They are: Arizona, Florida, Illinois, Indiana, Kentucky, Maryland, Michigan, Missouri, Nebraska, Nevada, New York, Ohio, Oregon, Pennsylvania, South Dakota, Tennessee, Virginia, and West Virginia.

The basis of the initial data preparation is the calendar year. Monthly and annual gas-well production data from Dwight's. and EIA data series are not always the same; however, the differences in production between the two sources has generally been small. Annual adjustment factors were developed and applied to Dwight's EnergyData Inc. data to ensure that the difference between the production data from the two sources was eliminated on an annual basis. However, the historical monthly production data presented in this report may still differ from the monthly data published in other EIA publications.

\section{Gas-Well Gas Productive Capacity}

The first step in estimating gas-well productive capacity is to obtain the production for each gas-well completion in every State or multi-State area by month. This was available from Dwight's. data files for all States and areas except for the 18 States previously identified where monthly production data were available from EIA but not by well completion. Data edits were performed on the historical monthly data.

The historical average vintage productive capacities on a per well basis are then established and projected using the estimated number of monthly new wells going on production. The estimated 1995 history and the projected 1996 and 1997 productive capacities (low, base, and high cases) are based on the Wellhead Productive Capacity Model (GASCAP) described in Appendix B.

\section{Historical Production}

The monthly gas-well production belonging to each State or area vintage is tabulated and plotted versus cumulative production. Vintage gas-well production is defined as the production from all well completions in a State or area with first production beginning in the same calendar year. For example, production from all well completions going on stream for the first time in Texas in 1972 would be called the Texas 1972 vintage gas-well production.

\section{Historical Productive Capacity}

A peak production rate is determined each year for every vintage in each State or area. The peak-rate selected is the sum of all of the gas-well completion peak-rates within a particular vintage year without regard to the month in which the gas-well completion peak-rate occurred. It is assumed that if a gas-well completion in a vintage produced at a maximum rate during any month of the year, the gas-well completion should have been capable of at least this production rate in prior months.

After the annual peak rates are determined, they are screened (Figure A1) to eliminate those that are not near capacity. The first peak rate in each vintage is eliminated because not all of the gas-well completions have produced gas for the entire first year. Furthermore, beginning with the last annual point, each point is compared with the previous year's point 


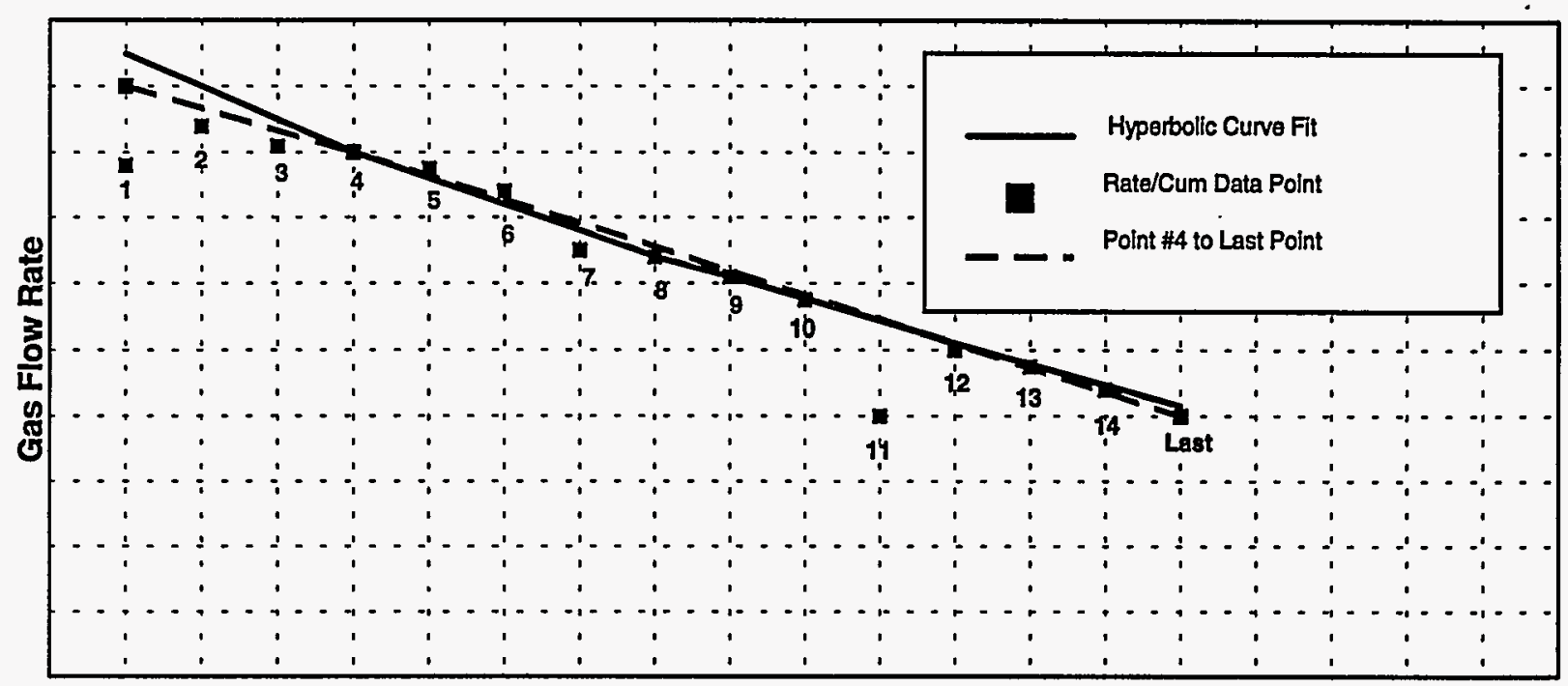

\section{Cumulative Production}

Note: Point Reason for Point Rejection

1 Point 1 Always omitted

2 \& 3 Falls below straight line connecting 4th and last points

7 More than one standard deviation below the estimated value

11 Point 12 is larger

Source: Energy Information Administration, Office of Oil and Gas.

until the initial point is reached. If the previous point is higher, it is retained. If it is lower, it is rejected (point 11). This is done because a rate versus cumulative production curve should show a decline when the wells are producing near productive capacity. Next, a straight line connected by the fourth and last points is extended backward through the second and third points. The second and third points are rejected if these points fall below the straight line. This process is repeated using the last and third data points to check the second data point. If the data points fall below both straight lines, it is assumed that the low peak rates could be due to reasons other than physical limitations of the wells--for example, low demand, proration, or temporary mechanical problems.

The next step is to fit the remaining points with a hyperbolic curve. A hyperbolic curve fit is chosen because it is the decline curve most often encountered. For example, Figure A2 shows a hyperbolic fit for the peak rates versus cumulative gas production for the 1982 vintage wells in the Gulf of Mexico OCS. Initial estimates are made for the initial rate ( $q I$; the $Y$ intercept), and ultimate recovery ( $G_{u l}$; the $X$-intercept). Although this curve might appear to be exponential, there is a slight curvature. The exponent $B$ is close to one
(1), indicating that the curve comes close to being an exponential curve.

The rate versus cumulative production relationship $\{19\}$ for the hyperbolic decline is:

$$
G_{p}=\frac{q_{i}^{b}}{D_{i}(1-b)}\left(q_{i}^{1-b}-q^{1-b}\right)
$$

where $G_{p}=\underset{\text { feet }}{\text { cumulative gas produced, thousand cubic }}$

$q_{i} \quad=$ initial gas flow rate at capacity, thousand cubic feet per day

$q \quad=$ gas flow rate at capacity, thousand cubic feet per day

$D_{i} \quad=$ initial daily decline rate

$b \quad=$ hyperbolic decline exponent. 
Figure A2. Gross Gas-Well Gas Productive Capacity for the Gulf of Mexico OCs 1982 Vintage

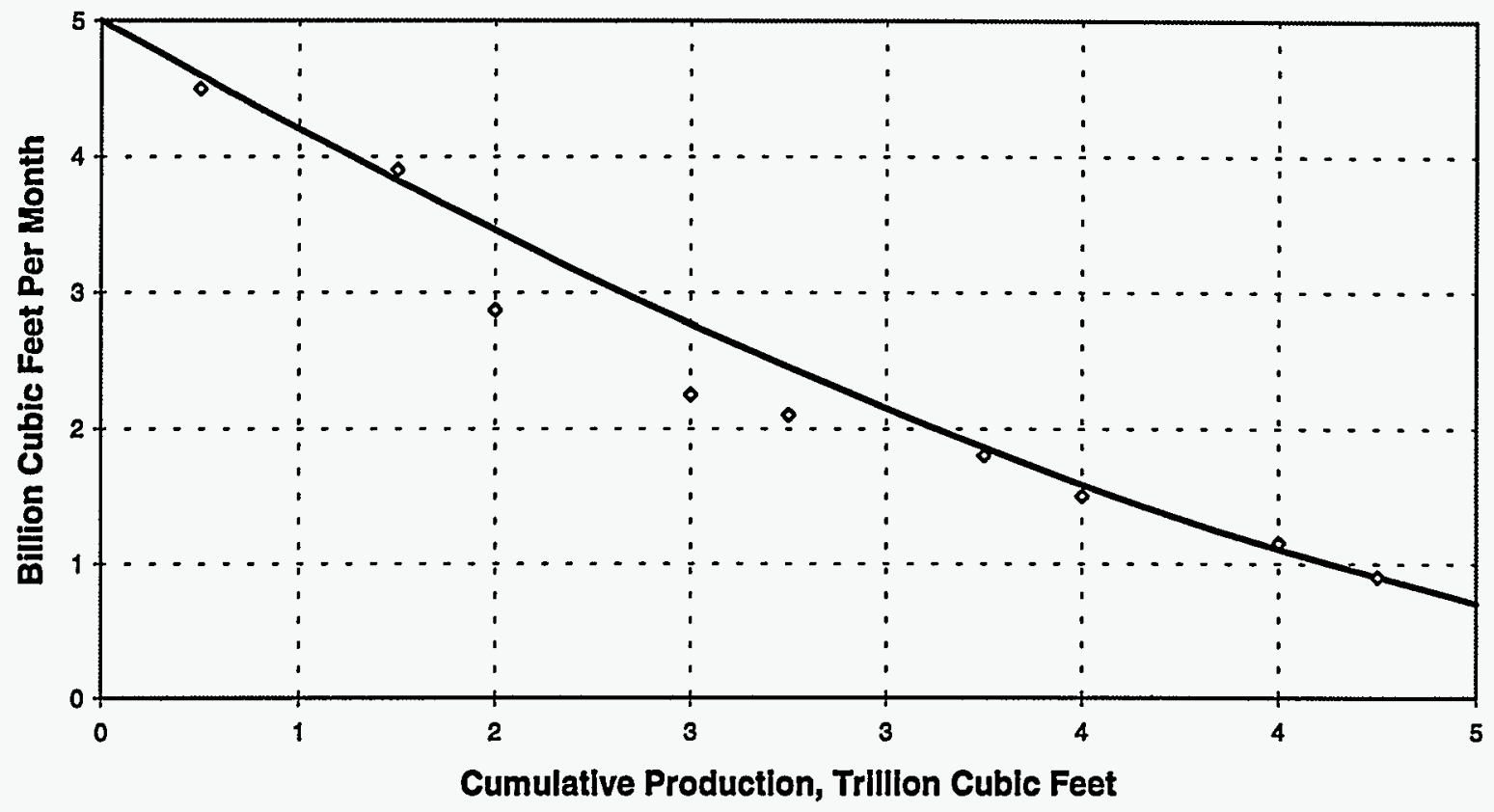

Source: Energy Information Administration Model GASCAP C051995, based on production data from Dwight's Energydata, Inc.

In equation (A1), cumulative gas produced, $G_{p}$, becomes the ultimate recoverable gas, $G_{u l}$, when the flow rate, $q$, is at abandonment conditions. Assuming that the flow rate, $q$, at abandonment conditions is zero, equation (A1) becomes:

$$
G_{u l}=\frac{q_{i}}{D_{i}(1-b)}
$$

Rearranging (A1),

$$
q=\left[q_{i}^{1-b}-\frac{D_{i}(1-b)}{q_{i}^{b}} G_{p}\right]^{1 /(1-b)}
$$

Simplifying (A3),

$$
q=q_{i}\left[1-\frac{D_{I}(1-b)}{q_{i}} G_{p}\right]^{1 /(1-b)}
$$

Substituting (A2) in (A4),

$$
q=q_{i}\left[1-\frac{G_{p}}{G_{u l}}\right]^{1 /(1-b)}
$$

Substituting $B$ for $\frac{1}{1-b}$,

$$
q=q_{i}\left[1-\frac{G_{p}}{G_{u l}}\right]^{B}
$$

Equation (A6) is used to describe the hyperbolic decline of the peak flow rates of each vintage curve.

In 1956, J.J. Arps in his report entitled Estimation of Primary Oil Reserves $\{19\}$ state that W.W. Cutler, Jr., of the U.S. Bureau of Mines \{20\} indicated that most decline curves normally encountered are of the hyperbolic type, with values for the exponent $b$ between 0 and 0.7 , with the majority falling between 0 and 0.4 . This means that the values of the exponent $B$ are between 1.0 and 3.3 , with the majority between 1.0 and 1.7. The accepted range for $B$ in the GASCAP model is from 1.001 to 3.0 . The lower value of 1.001 was chosen rather than 1.0 because a value of 1.0 used in equation (A9) would 
result in division by 0 , a forbidden operation. Values of $B$ greater than 3.0 tend to give unrealistically large values of $G_{u l}$. Also, the raw production data are often distorted by low gas demand. This causes an apparent very rapid production rate decline and an accompanying large $B$ that is not based on the physical capability of wells to produce gas. A data screening algorithm was used during the decline curve fitting process to identify low production rate data points caused by low demand. The highest $B$ allowed during a curve fit to initiate this process was 3.0.

Productive capacity rather than peak rate is desired for the vintage curves. However, only the vintage curve's peak rate could be obtained. Peak rate is close to productive capacity if the demand for gas is much higher than normal for at least 1 month during the year. In the model, demand is defined as the monthly gas volume produced for the lower 48 States, State/areas, or vintage. If demand were to remain low for every month of the year, the highest peak rate for the year would be lower than the actual productive capacity.

Another screening process is performed to eliminate low rates that could be a result of low demand. If an actual or observed point is more than one standard deviation lower than the corresponding calculated value on the vintage curve, the actual point is rejected. The remaining data points are then refitted keeping $B$ constant and allowing $q_{i}$ and $G_{u l}$ to vary. This process is applied to all vintages except the last three.

The initial rates $\left(q_{i}\right)$ for the last three vintage years are calculated independently of the regression analysis. The qI for the last historical vintage year is an historical average on a per well basis, as described later. The $q_{i}$ for the previous two vintages is determined by averaging the ratio between the calculated $q_{i}$ and the peak rate in the second year of production. These average ratios are taken for the 7 years prior to the last 3 years, and are multiplied by the peak rate in the second year of production to provide a fixed $q i$.

For the projections of capacity for vintage curves beginning with the last historical vintage year, the values of $q_{i}, G_{p}$, and the corresponding $q$ are needed on a well completion basis and are obtained by averaging these values for the last 3 historical vintage years, not including the last one. The gas flow rate, $q_{v}$, is the average of the per-well capacities for December of the second production year. $G_{p v}$ is the average gas produced per well through December of the second production year. $G_{u l v}$ is the average ultimate recovery on a per well completion basis and is obtained by substituting the previously derived values for $q_{i v}, G_{p v}$, and $q_{v}$ in the following equation, which is a rearrangement of equation (A6) after each term by the number of gas-well completions, $v$,

$$
G_{u l v}=\frac{G_{p v}}{1-\left(q_{v} / q_{i v}\right)^{1 / B}} .
$$

The $q_{i}$ and $G_{u l}$ on a per-well completion basis are multiplied by the number of new well completions in each year to obtain the $q_{i}$ and $\mathrm{Gul}$ for each year.

\section{Projections of Productive Capacity}

\section{Projected Productive Capacity of Old Vintage Wells}

After the historical productive capacity vintage curves are developed through the last historical data year, they are projected for 3 years. Productive capacity curves also had to be developed for all well completions going on stream in these projected years. It is assumed that the productive capacity for the total well completions beginning production during the vintage year will increase throughout the vintage year and will start to decline the next year.

To start the projection routine, the flow rate at capacity is calculated from each vintage for each month starting in January of the first projected year. The production for each vintage for any month is calculated by allocating the expected demand to each vintage based on the capacity of each vintage. The cumulative production for each vintage is the sum of the cumulative production at the beginning of the month and the allocated production. The new well completions (well completions going on production in each month for the first time) are used for the current vintage capacity calculations.

All old vintages are projected for 3 years. The production rate as a function of cumulative production, $G_{p}$, is given by equation (A6). The production rate can also be written as a function of time, $t$, as described by Arps, although in his formulation, $B=\frac{1}{(1-b)}$ :

$$
q=q_{i}\left[1+\frac{q I(B-1) t}{G_{u l}}\right]^{B /(1-B)}
$$


Equation (A8) is the hyperbolic equation that describes production rate decline as a hyperbolic function of time.

The time, $t$, that corresponds to the vintage productive capacity at the beginning of the month is calculated by solving equation (A8):

$$
t=\frac{G_{u l}\left[\left(q / q_{i}\right)^{(1-B) / B}-1\right]}{(B-1) q_{i}}
$$

where $q$ is the flow rate at capacity (productive capacity) at the beginning of the month. The number of days in the month are added in order to step forward and calculate the vintage productive capacity at the beginning of the next month.

The maximum possible cumulative production to the end of the month is calculated by using the following equation, which is a rearrangement of equation (A6):

$$
G_{p}=G_{u l}\left[1-\left(q / q_{i}\right)^{1 / B}\right]
$$

Furthermore, the productive capacities for the nine areas are multiplied by load factors. The load factors are applied because gas-well completions are frequently shut-in because of mechanical problems. In the model, annual load factors for the last 10 historical years are derived by dividing the annual production from all gas-well completions producing in December of a specific year by the annual production from all gas-well completions that produced in any month during the same year. The load factor for each area is obtained by taking an average of the 10 annual load factors.

The cumulative gas produced to the beginning of a specific month is subtracted from the maximum possible cumulative gas produced at the end of the month to yield maximum productive capacity for the month for each vintage.

The productive capacities for each vintage year are summed and the demand is allocated to each vintage by its percentage of the total capacity. Next, the allocated production is added to the cumulative production at the beginning of a specific month for each vintage, and the process is repeated, starting with the calculation of time $(t)$ in equation (A9).

Figure A3 displays the historical production rates, the adjusted peak rate, the theoretical peak capacity rate, and the projected rates for vintage year 1982 for the Gulf of Mexico OCS.

Figure A3. Capacity and Production Rates for the Gulf of Mexico OCS 1982 Vintage Year

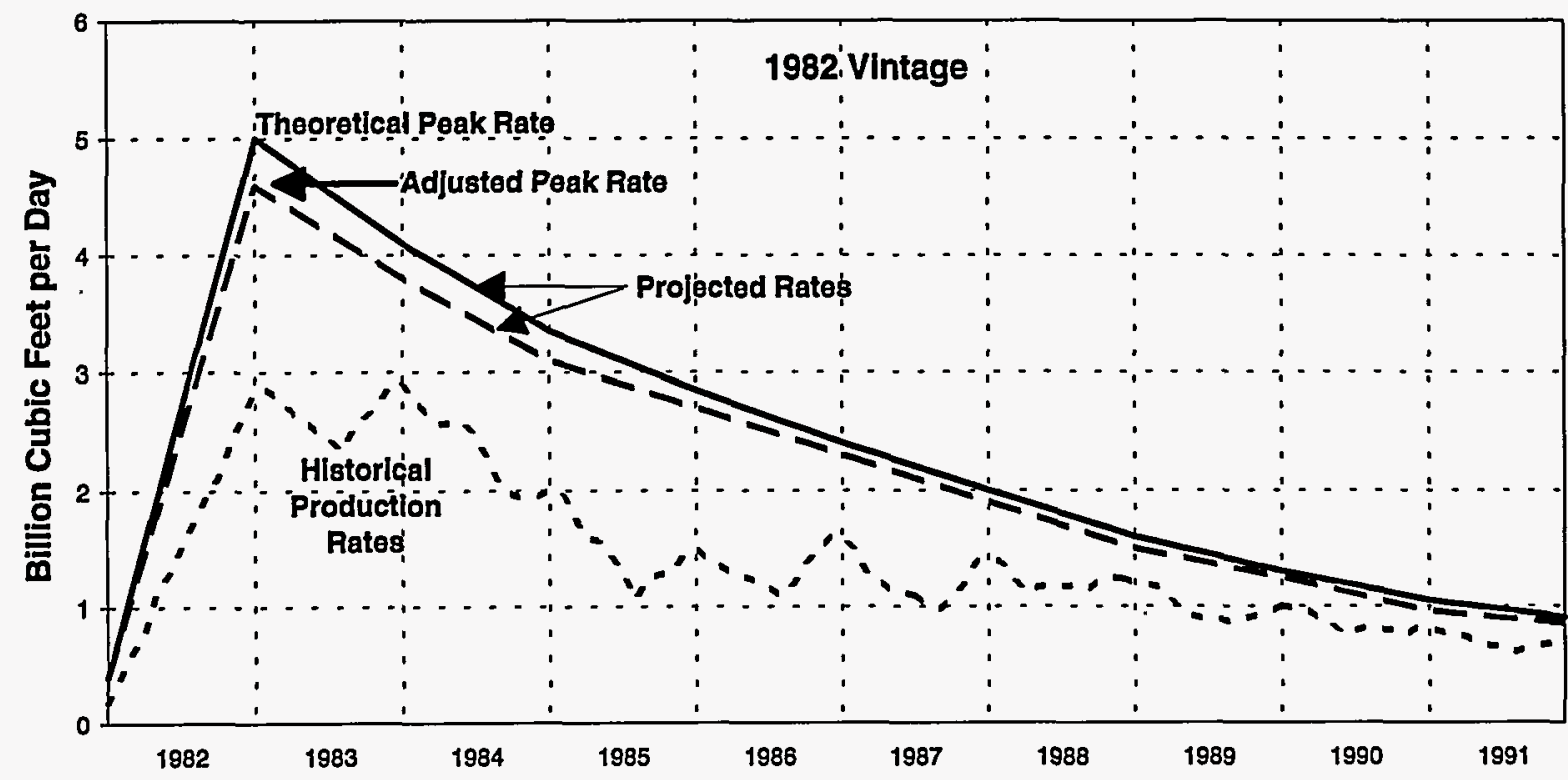

Sources: Production: Energy Information Administration, Office of Oil and Gas and Dwight's Energydata, Inc. Theoretical and adjusted peaks: Model GASCAP93 C060194. 


\section{Projected Productive Capacity of New Vintage Wells}

Demand is defined for this model to be the volume of gas required from gas-well completions. Productive capacity is defined as the maximum volume of gas a gas-well can produce for a month.

If demand approaches the productive capacity of the old wells, the new wells (i.e., wells with near original capacity) will be called upon to produce at higher daily rates. This will cause the capacities of wells brought on in January to begin a higher rate of decline than normal (what usually happens in the historical data). Therefore, the productive capacity of wells brought on in January will be significantly less than their initial capacity, and the cumulative production $\left(G_{p}\right)$ will be higher at the end of the year. If, however, demand decreases as a percentage of productive capacity, the new wells will not be required to produce at as high a rate as is normal. Their productive capacity will be greater than normal, and their corresponding cumulative production will be less at the end of the first year (Figure A4). A theoretical hyperbolic type curve illustrates this discussion. The difference in the cumulative production $\left(G_{p}\right)$ is the difference between the annual production under normal demand (Case 1) and low demand (Case 2) at the end of the first year. Since capacity has been defined as a function of cumulative production, the difference in cumulative production for a low demand year or a high demand year can be determined by subtracting the actual cumulative production from the historical normal cumulative production (mean production rates for all previous vintage years per well completion). The capacity can be adjusted to account for low (or high) demands during the first year. This is done on a monthly basis for the first year of production for each new vintage year. The difference in cumulative production at the end of the first year is also used to adjust the cumulative production and, therefore, the capacity in all subsequent years.

Monthly productive capacity for a new vintage year is a function of the wells completed during the month plus the amount contributed by wells completed earlier in the year. For each month, the productive capacity for wells completed that month is assumed to be one-half of the month's well completions times the average initial rate $\left(q_{i}\right)$ per well for the previous three vintage years (obtained as described earlier). The productive capacity for earlier wells is determined as a function of normal cumulative production modified by the need to

Figure A4. Theoretical Hyperbolic Type Curve for Production and Capacity

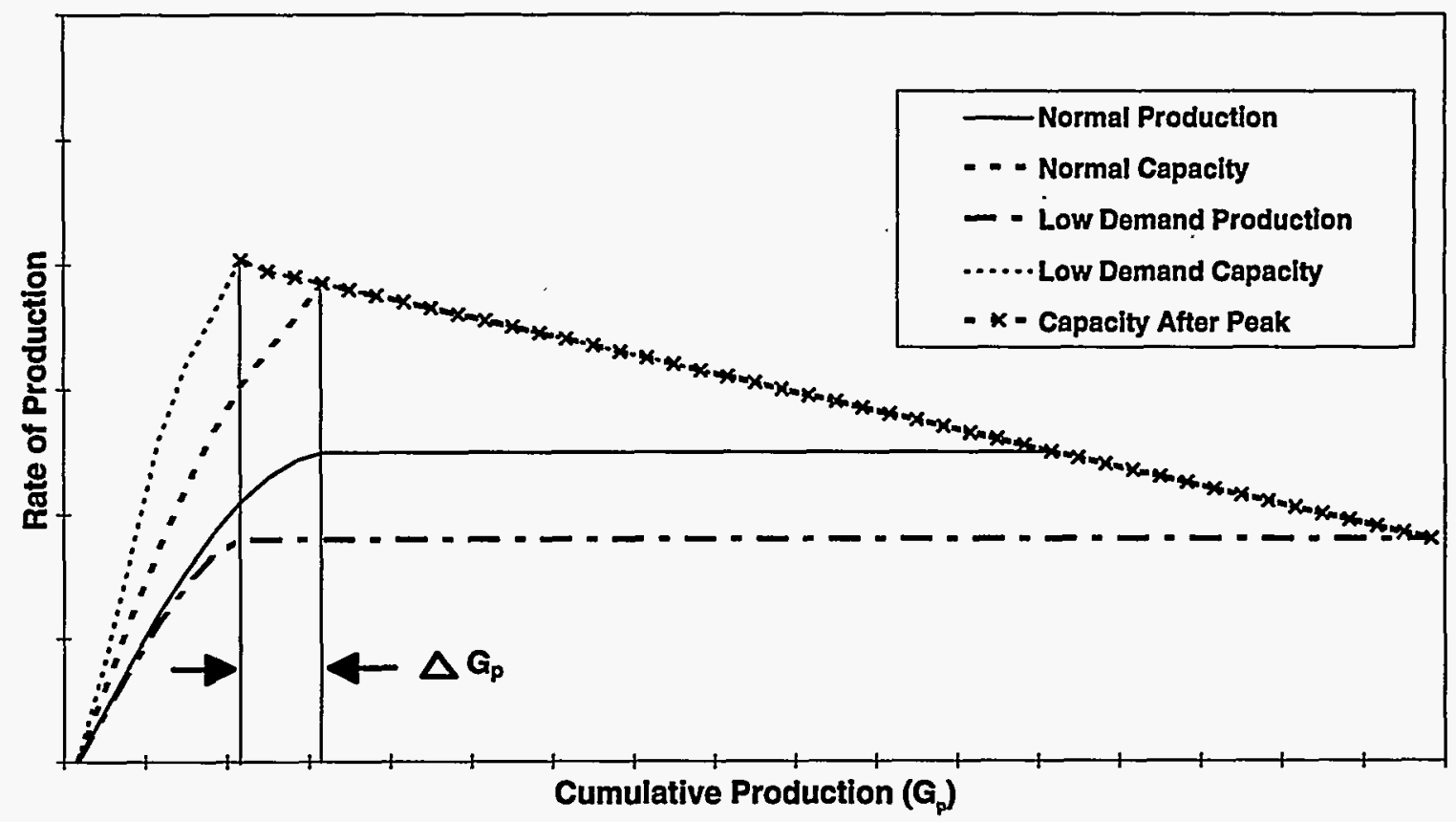

Source: Energy Information Administration, Office of Oil and Gas. 
meet the allocated demand from the wells completed in the prior months.

The equation is as follows:

$q_{k}=\left(0.5 v_{k}+\sum_{j=0}^{k-1} v_{j}\right)\left(\frac{q_{i}}{v}\right)\left[1-\frac{\sum_{j=0}^{k-1} \Delta G_{p_{j}}}{\left(\frac{G_{u l}}{v}\right) \sum_{j=0}^{k-1} v_{j}}\right]^{B}$,

where

$$
\begin{aligned}
& q_{k}=\text { productive capacity in month } k \text {, thousand } \\
& v_{k}=\text { number of gas-well completions for }
\end{aligned}
$$

The normal cumulative production is the average historical cumulative production per well of preceding vintages multiplied by the new well completions.

\section{Projected Productive Capacity for the 18 States}

Because production and well counts by vintage year are not available for 15 of the 18 States, a different approach is taken for this group of States. Monthly peak rates are determined from monthly gas-well production data obtained from the Natural Gas Monthly, and the number of new well completions is determined from the API drilling statistics.
The following equation describes the current year's productive capacity as a function of last year's productive capacity and productive capacity from wells brought on in the last 12 months or during the last year.

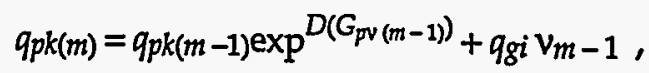

where

$$
\begin{aligned}
& m \quad=\text { year } \\
& q_{p k} \quad=\begin{array}{l}
\text { peak production rate, thousand cubic feet } \\
\text { per day }
\end{array} \\
& D \quad=\begin{array}{l}
\text { decline rate of old production, wells per } \\
\text { billion cubic feet }
\end{array} \\
& G_{p v} \quad=\begin{array}{l}
\text { cumulative production per well, billion } \\
\text { cubic feet per well }
\end{array} \\
& v \quad=\begin{array}{l}
\text { total number of new gas-well } \\
\text { completions for the year }
\end{array} \\
& q_{g i} \quad=\begin{array}{l}
\text { initial gas production rate for new wells, } \\
\text { thousand cubic feet per day. }
\end{array}
\end{aligned}
$$

For projection purposes the equation was converted to a monthly basis as follows:

$$
\begin{aligned}
& q p k(m, n) \\
& \text { where }
\end{aligned}
$$

$$
\begin{aligned}
& m \quad \text { = year } \\
& n \quad=\text { month } \\
& q p k(m, n)=\text { peak production rate for year }(\mathrm{m}) \text { and } \\
& \text { month (n) } \\
& q_{p k(m, 1)}=\text { calculated January peak production } \\
& \text { rate for year }(\mathrm{m}) \text { used as the starting } \\
& \text { point to accumulate new well } \\
& \text { completions for monthly projections } \\
& D \quad=\text { decline rate for old production, wells } \\
& \text { per billion cubic feet } \\
& G_{p(m, n-1)}=\text { cumulative production per well, to } \\
& \text { month } n-1 \text { for year }(m) \text {, billion cubic } \\
& \text { feet per well } \\
& v_{m, n-1}=\text { new well completions to month }(n-1) \\
& \text { for year }(m) \\
& q_{g i} \quad=\text { initial production rate for new wells, } \\
& \text { thousand cubic feet per day. }
\end{aligned}
$$




\section{Oil-Well Gas Productive Capacity}

Oil-well gas productive capacity is estimated for the same States and areas as gas-well gas productive capacity. Oil wells are considered to be producing at their normal and full capacity as required by the lease operators and State proration/regulation requirements. Oil-well gas production is a function of oil production and the producing gas-oil ratio (GOR); therefore, the difference between productive capacity and gas production for oil wells was assumed negligible.

Gross gas production from oil wells for each State is available on an annual basis only. Therefore, monthly gross gas production from oil wells from 1985 through 1994 was calculated. The annual GOR is calculated by dividing the annual gross oil-well gas production\{13\} by the annual oil production. $\{21\}$ Then the monthly oil production is multiplied by the appropriate GOR. The monthly oil production estimates for each State and area for 1995, 1996, and 1997 were multiplied by the corresponding 1994 GOR to yield the forecast of the monthly oil-well gas productive capacity for 1995, 1996, and 1997.

\section{Coalbed Gas Productive Capacity}

Coalbed gas-well completion productive capacity is estimated by using the same basic method as for a conventional gas-well completion.

Coalbed gas-well completion productive capacity data was obtained from Dwight's EnergyData, Inc., Oil and
Gas Reports, Richardson, TX. The coalbed gas-well completions were grouped in vintage years, as was done for the conventional gas wells, for New Mexico, Rocky Mountain, and Southeast areas. After an historical review of the vintage data, a typical production profile curve for each area and vintage was produced. All coalbed gas completions commencing production prior to the beginning of 1989 were included in the 1988 vintage. Coalbed gas production prior to 1988 consisted of a few wells scattered over many years which produced at low rates. Including all wells prior to 1989 in vintage 1988 facilitated handling the projections of older completions. Table A1 shows the vintage years for each area, along with the cumulative production and the number of wells included in the vintage year.

Coalbed gas well production curves are quite different from conventional gas well production curves. Coalbed gas production increases during the first few years of the life of the well. The production increase is due to gas desorbing from the water and the coal as the pressure is reduced on the reservoir fluids. Production peaks at upward of five years after initial production before starting to decline. Traditional decline curve analysis and the GASCAP model will not handle these first few years of increasing production. A projection curve was developed to match the production profile of a typical coalbed gas-well completion (Figure A5).

To develop a coalbed gas-well production profile curve, the annual peak production rate versus time for the average completion was plotted for each vintage. A matching curve was then fitted to the annual peak points and extended out to the year where production

Table A1. Coalbed Gas Cumulative Production and Number of Completions by Area for Vintage Years 1988 - 1994

\begin{tabular}{|c|c|c|c|c|c|c|}
\hline \multirow[b]{2}{*}{$\begin{array}{l}\text { Vintage } \\
\text { Year }\end{array}$} & \multicolumn{2}{|c|}{ NEW MEXICO } & \multicolumn{2}{|c|}{ ROCKY MOUNTAIN } & \multicolumn{2}{|c|}{ SOUTHEAST } \\
\hline & $\begin{array}{c}\text { Cumulative } \\
\text { Productlon } \\
\text { (MMct) }\end{array}$ & $\begin{array}{l}\text { Number } \\
\text { Of Wells }\end{array}$ & $\begin{array}{l}\text { Cumulative } \\
\text { Production } \\
\text { (MMcf) }\end{array}$ & $\begin{array}{l}\text { Number } \\
\text { Of Wells }\end{array}$ & $\begin{array}{c}\text { Cumulative } \\
\text { Production } \\
\text { (MMcf) }\end{array}$ & $\begin{array}{l}\text { Number } \\
\text { Of Wells }\end{array}$ \\
\hline 1988 & 185,446 & 99 & 92,086 & 171 & 102,330 & 484 \\
\hline 1989 & 394,359 & 250 & 80,959 & 140 & 68,100 & 408 \\
\hline 1990 & 468,266 & 364 & 96,425 & 201 & 150,422 & 961 \\
\hline 1991 & 503,714 & 497 & 120,668 & 164 & 105,673 & 1030 \\
\hline 1992 & 217,150 & 372 & 52,676 & 141 & 13,109 & 197 \\
\hline 1993 & 87,875 & 429 & 59,526 & 230 & 14,006 & 140 \\
\hline 1994 & 8,315 & 219 & 5,127 & 78 & 2,029 & 88 \\
\hline
\end{tabular}

Note: Cumulative Production through December 1994 and vintage 1988 includes all previous completed coalbed gas wells.

Sources: Energy Information Administration, Office of Oil and Gas and Dwight's EnergyData, Inc. 
would reach or was expected to reach its maximum. A second matching curve starting at the maximum peak rate was projected to decline exponentially for the remainder of a well life of thirty years. Since most of the production data from these completions is less than six years old, there are very little well decline data available. Historical and industry data indicate that an 8 percent decline is most likely for coalbed gas completions in their later life, and this decline rate was used as a basis for simulating the exponential decline.

The matching curves were used as the basis for generating a vintage well production profile curve by using the production rate-cumulative production and production rate-time equations. Iterative solutions of these equations were made until a unique set of constants $A, B$, and $C$ for the vintage profile were found. The equations were solved so that the vintage production profile matched as closely as possible the actual annual peak production rates.

The production rate versus cumulative production relationship is:

$$
q=\frac{-G_{p}}{B}\left(-\ln A+\ln G_{p}\right)^{2}
$$

The data from the matching curve for a production rate $(q)$ and the corresponding cumulative production $\left(G_{p}\right)$ were used to solve for constants $A$ and $B$ in equation (A14). Iterations of the EXCEL 5.0 SOLVER routine were used to force the curve generated by equation (A14) to track the simulated data curve. The values for constants $A$ and $B$ calculated from equation (A14) were then substituted into equation (A15) and solved for $C$. The time versus cumulative production relationship is:

$$
C=-t+\left[B /\left(\ln A+\ln G_{p}\right)\right] \text {. }
$$

This solution for $C$ the EXCEL 5.0 SOLVER routine was used again to find the values of $A$ and $B$ using equation (A16). The results from equation (A16) were used to generate a curve similar to the curve generated by equation (A14). Equation (A16) for the rate versus time relationship is:

$$
q=A\left[\exp ^{B /(C+t)}\right]\left[-B /(C+t)^{2}\right]
$$

Each of the above three equations can be used with a unique set of $A, B$, and $C$ that will describe coalbed gas well production profile curves that are very close. The EXCEL 5.0 Solver routine was run a final time to find identical values of $A$ and $B$, using $C$ that would force

\section{Flgure A5. New Mexico Coalbed Gas-Well Completion Production and Peak Production Rate}

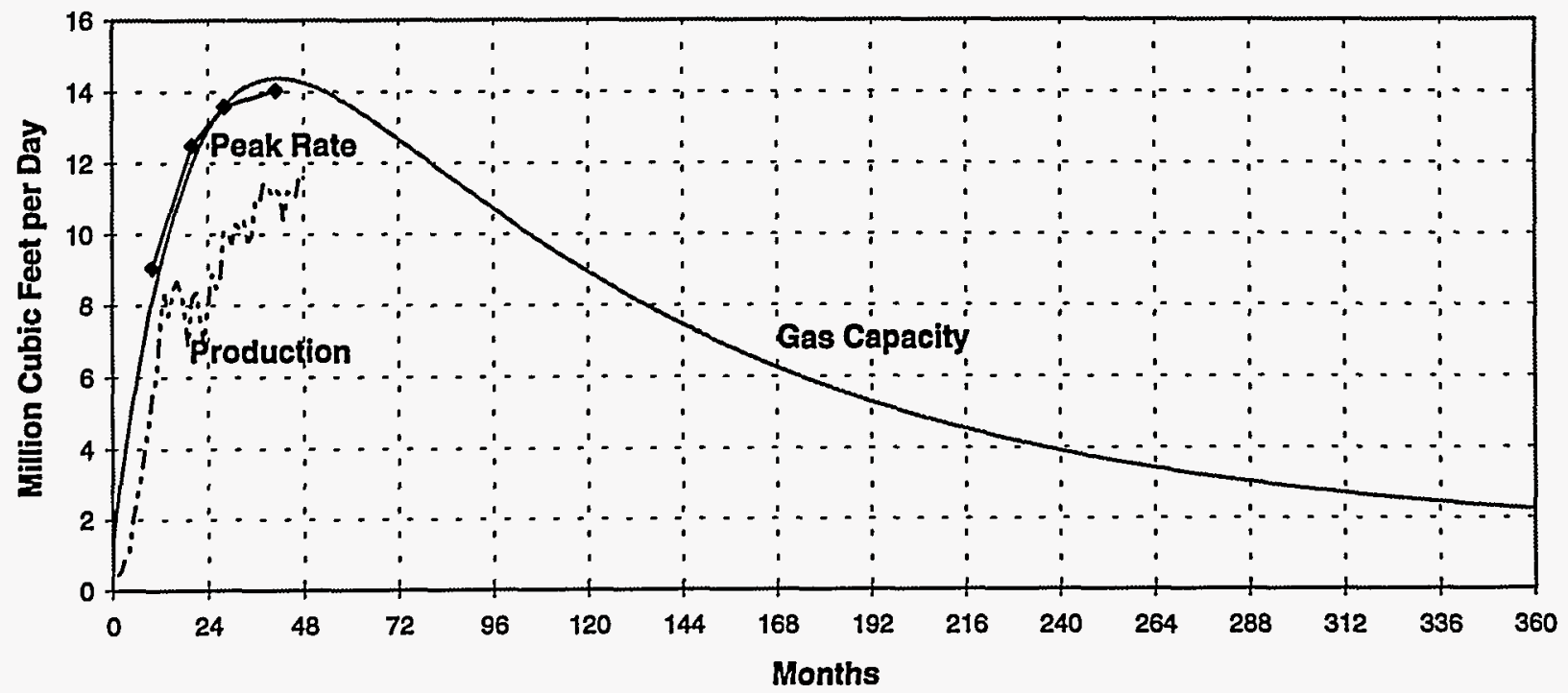

Source: Energy Information Administration, Office of Oil and Gas and Dwight's EnergyData, Inc. 
equations (A14) and (A16) generated curves to be as close together as possible. This final value for $A, B$, and $C$ is then used in the SAS runs for forecasting the coalbed gas capacity. Figure A5 shows the final peak rate curve generated by this technique.

This technique was used to generate production for all the coalbed gas-well for all vintages in all areas.

\section{Gas Demand}

The forecast of the gas demand that will be met by domestic production is available on a quarterly basis for the United States for 1996, and 1997 in Table 10 of the Short-Term Integrated Forecasting System, Fourth Quarter 1996. \{11\} The lower 48 States dry gas demand for each quarter was obtained by subtracting Alaska's projected production from the U.S. gas demand (Table A2) and was distributed to each State or area. Since dry gas data are not available on a quarterly basis, but marketed production data are for each State or area (Table A3), the latter are converted to quarterly dry gas (Table A4). For example, in Texas (excluding Gulf of Mexico OCS), the first quarter's marketed production of 1,227,016 million cubic feet (Table A3) is multiplied by .92574 (Table A3) to obtain the dry gas production of $1,135,897$ million cubic feet (Table A4). Then the quarterly dry gas production is added for all the areas for each quarter (Table A4). The quarterly dry gas is divided by total dry gas for that quarter and is expressed as a fraction (Table A5). To obtain quarterly gross gas demand for each area (Table A6), the lower-48 gas demand is multiplied by the quarterly dry gas fraction for that State or area and by the ratio of gross gas to dry gas for that State or area. The reason for conversion of demand from dry gas to gross gas basis is that the gas production data from Dwight's are on a gross gas basis.

The quarterly gross gas (gas-well gas plus oil-well gas) is then distributed on a monthly basis for each State or area on its monthly marketed production for 1994. The monthly gross oil-well gas production was determined by multiplying the 1994 annual GOR by the monthly historic oil production for each State or area from 1985 through 1994. Monthly gas production from oil wells was then subtracted from monthly gross gas to get gas production from gas wells.

The monthly gross gas-well gas demand for each State or area was then compared with the monthly gross gas-well gas productive capacity. If the productive capacity was equal to or greater than the demand, the demand was scheduled as production. If the

Table A2. Quarterly Dry Gas Production Forecast, 1996 and 1997 (Trillion Cubic Feet)

\begin{tabular}{|c|c|c|c|c|c|}
\hline Dry Gas Production & $\begin{array}{c}\text { First } \\
\text { Quarter }\end{array}$ & $\begin{array}{l}\text { Second } \\
\text { Quarter }\end{array}$ & $\begin{array}{c}\text { Third } \\
\text { Quarter }\end{array}$ & $\begin{array}{l}\text { Fourth } \\
\text { Quarter }\end{array}$ & Total \\
\hline \multicolumn{6}{|l|}{1996} \\
\hline $\begin{array}{l}\text { U.S. Total Dry Gas Production ................... } \\
\text { Alaska Total Dry Gas Production ............. } \\
\text { Lower-48 total Dry Gas Production ........... }\end{array}$ & $\begin{array}{l}4.719 \\
0.114 \\
4.605\end{array}$ & $\begin{array}{l}4.772 \\
0.102 \\
4.670\end{array}$ & $\begin{array}{l}4.782 \\
0.097 \\
4.685\end{array}$ & $\begin{array}{l}4.804 \\
0.110 \\
4.694\end{array}$ & $\begin{array}{r}19.077 \\
0.423 \\
18.654\end{array}$ \\
\hline \multicolumn{6}{|l|}{1997} \\
\hline $\begin{array}{l}\text { U.S. Total Dry Gas Production ................... } \\
\text { Alaska Total Dry Gas Production ............. } \\
\text { Lower-48 total Dry Gas Production .......... }\end{array}$ & $\begin{array}{l}4.930 \\
0.114 \\
4.816\end{array}$ & $\begin{array}{l}4.867 \\
0.102 \\
4.765\end{array}$ & $\begin{array}{l}4.914 \\
0.097 \\
4.817\end{array}$ & $\begin{array}{l}4.990 \\
0.110 \\
4.880\end{array}$ & $\begin{array}{r}19.701 \\
0.423 \\
19.278\end{array}$ \\
\hline
\end{tabular}

Source: Energy Information Administration, Short-Term Integrated Forecasting System, Fourth Quarter 1996. 
Table A3. Marketed, Dry, and Gross Gas Productlon for 1994 (Million Cubic Feet)

\begin{tabular}{|c|c|c|c|c|c|c|c|c|c|}
\hline \multirow[b]{2}{*}{ State/Area } & \multicolumn{5}{|c|}{ Marketed Gas Production } & \multicolumn{4}{|c|}{$\begin{array}{c}\text { Dry and Gross Gas } \\
\text { Productlon and Ratlos }\end{array}$} \\
\hline & $\begin{array}{c}\text { First } \\
\text { Quarter }\end{array}$ & $\begin{array}{l}\text { Second } \\
\text { Quarter }\end{array}$ & $\begin{array}{c}\text { Third } \\
\text { Quarter }\end{array}$ & $\begin{array}{l}\text { Fourth } \\
\text { Quarter }\end{array}$ & Total & $\begin{array}{l}\text { Dry } \\
\text { Gas } \\
\end{array}$ & $\begin{array}{c}\text { Dry'l } \\
\text { Mkt }\end{array}$ & $\begin{array}{c}\text { Gross } \\
\text { Gas }\end{array}$ & $\begin{array}{c}\text { Gross'/ } \\
\text { Dry }\end{array}$ \\
\hline Gulf of Mexico ........................ & $1,236,573$ & $1,252,443$ & $1,208,530$ & $1,209,808$ & $4,907,354$ & $4,831,500$ & 0.98454 & $4,942,637$ & 1.02300 \\
\hline 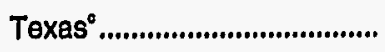 & $1,227,016$ & $1,261,144$ & $1,296,587$ & $1,260,938$ & $5,045,685$ & $4,670,988$ & 0.92574 & $5,603,550$ & 1.19965 \\
\hline 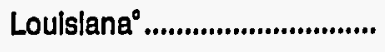 & 389,345 & 380,297 & 413,940 & 507,410 & $1,690,992$ & $1,629,631$ & 0.96371 & $1,712,116$ & 1.05062 \\
\hline Callforniad .................................. & 78,067 & 75,286 & 74,608 & 81,466 & 309,427 & 298,177 & 0.96364 & 395,752 & 1.32724 \\
\hline Kansas ....................................... & 196,535 & 170,277 & 157,261 & 188,658 & 712,731 & 665,794 & 0.93414 & 714,659 & 1.07339 \\
\hline New Mexico ........................... & 380,413 & 383,038 & 387,439 & 406,795 & $1,557,685$ & $1,471,082$ & 0.94440 & $1,581,797$ & 1.07526 \\
\hline 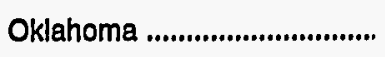 & 490,050 & 470,992 & 464,283 & 509,536 & $1,934,861$ & $1,833,300$ & 0.94751 & $1,934,864$ & 1.05540 \\
\hline \multicolumn{10}{|l|}{ Southeast } \\
\hline 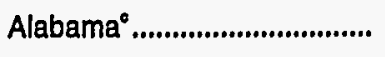 & 99,851 & 96,832 & 95,721 & 102,368 & - & 391,450 & - & 458,360 & - \\
\hline Arkansas .................................. & 47,074 & 45,672 & 45,669 & 49,257 & - & 187,120 & - & 195,413 & $\cdot$ \\
\hline Mississippl ................................. & 17,020 & 15,831 & 16,344 & 14,253 & - & 63,023 & - & 121,802 & - \\
\hline Total Southoast ............ & 163,945 & 158,335 & 157,734 & 165,878 & 645,892 & 641,593 & 0.99334 & 775,575 & 1.20883 \\
\hline \multicolumn{10}{|l|}{ Rocky Mountalns } \\
\hline Colorado ..................................... & 109,873 & 113,855 & 113,080 & 116,401 & - & 433,595 & - & 467,030 & - \\
\hline Montana ................................... & 13,959 & 11,809 & 11,069 & 13,579 & - & 49,785 & - & 51,072 & - \\
\hline North Dakota ............................ & 14,679 & 15,020 & 14,161 & 13,944 & - & 52,134 & - & 63,232 & - \\
\hline 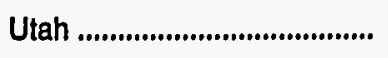 & 66,043 & 69,012 & 68,246 & 67,557 & $\cdot$ & 257,078 & - & 347,019 & - \\
\hline Wyoming ................................ & 172,241 & 180,645 & 177,880 & 165,253 & - & 662,532 & - & $1,070,862$ & - \\
\hline Total Rocky Mountains . & 376,795 & 390,341 & 384,436 & 376,734 & $1,528,306$ & $1,455,124$ & 0.95212 & $1,999,215$ & 1.37391 \\
\hline 18 States ............................. & 225,351 & 205,282 & 211,537 & 206,947 & 849,117 & 827,325 & 0.97434 & 862,585 & 1.04262 \\
\hline Lower-48 ........................... & $4,764,090$ & $4,747,435$ & $4,756,355$ & $4,914,170$ & $19,182,050$ & $18,324,514$ & & $20,522,750$ & \\
\hline
\end{tabular}

"Dry gas divided by marketed gas.

'Gross gas divided by dry gas.

'Excludes Gulf of Mexico OCS.

${ }^{\circ}$ Callfornia includes Pacific OCS.

$-=$ Not Applicable.

Note: Totals may not equal sum of components because of independent rounding.

Sources: Energy Information Administration, corrected data from Natural Gas Monthly and Natural Gas Annual 1994. 
Table A4. Quarterly Dry Gas Production by State and Area for 1994 (Million Cubic Feet)

\begin{tabular}{|c|c|c|c|c|c|}
\hline State/Area & $\begin{array}{c}\text { First } \\
\text { Quarter }\end{array}$ & $\begin{array}{l}\text { Second } \\
\text { Quarter }\end{array}$ & $\begin{array}{c}\text { Third } \\
\text { Quarter }\end{array}$ & $\begin{array}{l}\text { Fourth } \\
\text { Quarter } \\
\end{array}$ & Total \\
\hline 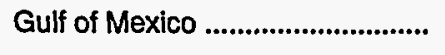 & $1,217,459$ & $1,233,084$ & $1,189,849$ & $1,191,108$ & $4,831,500$ \\
\hline Texas" & $1,135,897$ & $1,167,490$ & $1,200,301$ & $1,167,300$ & $4,670,988$ \\
\hline 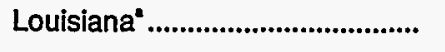 & 375,217 & 366,497 & 398,919 & 488,998 & $1,629,631$ \\
\hline California & 75,229 & 72,549 & 71,895 & 78,504 & 298,177 \\
\hline 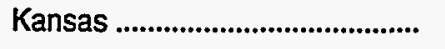 & 183,592 & 159,063 & 146,905 & 176,234 & 665,794 \\
\hline 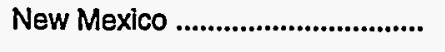 & 359,263 & 361,742 & 365,898 & 384,178 & $1,471,081$ \\
\hline Oklahoma & 464,327 & 446,270 & 439,913 & 482,790 & $1,833,300$ \\
\hline 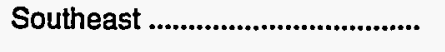 & 162,854 & 157,281 & 156,684 & 164,774 & 641,593 \\
\hline 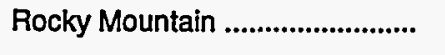 & 358,752 & 371,650 & 366,028 & 358,694 & $1,455,124$ \\
\hline 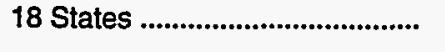 & 219,568 & 200,014 & 206,108 & 201,636 & 827,326 \\
\hline Lower-48 Total................... & $4,552,158$ & $4,535,640$ & $4,542,500$ & $4,694,216$ & $18,324,514$ \\
\hline
\end{tabular}

'Texas and Louisiana exclude Gulf of Mexico OCS.

'California includes Pacific OCS.

Note: Totals may not equal sum of components because of independent rounding.

Source: Energy Information Administration, Office of Oil and Gas.

Table A5. Quarterly Dry Gas Fraction by State and Area for 1994

\begin{tabular}{|c|c|c|c|c|}
\hline State/Area & $\begin{array}{c}\text { First } \\
\text { Quarter } \\
\end{array}$ & $\begin{array}{l}\text { Second } \\
\text { Quarter }\end{array}$ & $\begin{array}{c}\text { Third } \\
\text { Quarter } \\
\end{array}$ & $\begin{array}{l}\text { Fourth } \\
\text { Quarter } \\
\end{array}$ \\
\hline Gulf of Mexico & 0.26745 & 0.27187 & 0.26194 & 0.25374 \\
\hline Texas" & 0.24953 & 0.25740 & 0.26424 & 0.24867 \\
\hline Louisiana ${ }^{a}$ & 0.08243 & 0.08080 & 0.08782 & 0.10417 \\
\hline California ${ }^{b}$ & 0.01653 & 0.01600 & 0.01583 & 0.01672 \\
\hline 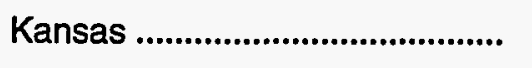 & 0.04033 & 0.03507 & 0.03234 & 0.03754 \\
\hline 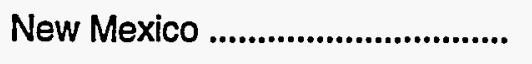 & 0.07892 & 0.07976 & 0.08055 & 0.08184 \\
\hline Oklahoma & 0.10200 & 0.09839 & 0.09684 & 0.10285 \\
\hline 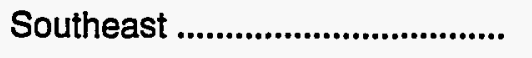 & 0.03578 & 0.03468 & 0.03449 & 0.03510 \\
\hline 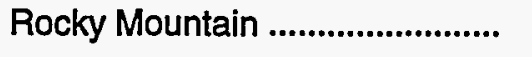 & 0.07881 & 0.08194 & 0.08058 & 0.07641 \\
\hline 18 States & 0.04823 & 0.04410 & 0.04537 & 0.04295 \\
\hline Lower-48 Total.................. & 1.00000 & 1.00000 & 1.00000 & 1.00000 \\
\hline
\end{tabular}

Texas and Louisiana exclude Gulf of Mexico OCS.

'California includes Pacific OCS.

Note: Totals may not equal sum of components because of independent rounding.

Source: Energy Information Administration, Office of Oil and Gas. 
Table A6. Quarterly Gross Gas Demand by State and Area for 1996 and 1997 (Trillion Cubic Feet)

\begin{tabular}{|c|c|c|c|c|c|}
\hline State/Area & $\begin{array}{c}\text { First } \\
\text { Quarter } \\
\end{array}$ & $\begin{array}{l}\text { Second } \\
\text { Quarter }\end{array}$ & $\begin{array}{c}\text { Third } \\
\text { Quarter }\end{array}$ & $\begin{array}{l}\text { Fourth } \\
\text { Quarter } \\
\end{array}$ & Total \\
\hline & \multicolumn{5}{|c|}{1996} \\
\hline Gulf of Mexico & 1.260 & 1.299 & 1.255 & 1.218 & 5.035 \\
\hline 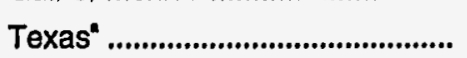 & 1.378 & 1.442 & 1.485 & 1.400 & 5.706 \\
\hline 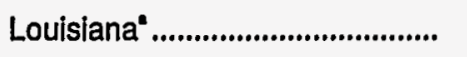 & 0.399 & 0.396 & 0.432 & 0.514 & 1.741 \\
\hline 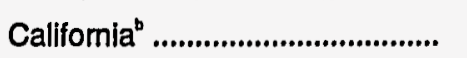 & 0.101 & 0.099 & 0.098 & 0.104 & 0.408 \\
\hline 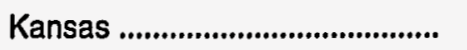 & 0.199 & 0.176 & 0.163 & 0.189 & 0.727 \\
\hline 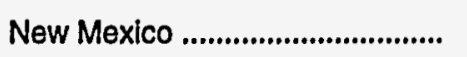 & 0.391 & 0.400 & 0.406 & 0.413 & 1.610 \\
\hline Oklahoma & 0.496 & 0.485 & 0.479 & 0.510 & 1.969 \\
\hline 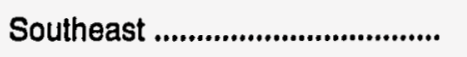 & 0.199 & 0.196 & 0.195 & 0.199 & 0.789 \\
\hline 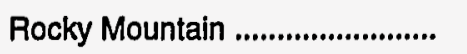 & 0.499 & 0.526 & 0.519 & 0.493 & 2.036 \\
\hline 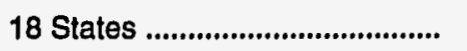 & 0.232 & 0.215 & 0.222 & 0.210 & 0.878 \\
\hline \multirow[t]{2}{*}{ Lower-48 Total..................... } & 5.153 & 5.234 & 5.254 & 5.251 & 20.892 \\
\hline & \multicolumn{5}{|c|}{1997} \\
\hline 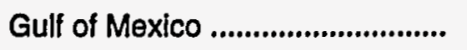 & 1.318 & 1.325 & 1.291 & 1.267 & 5.200 \\
\hline 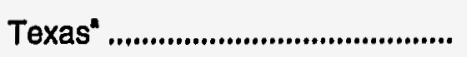 & 1.442 & 1.471 & 1.527 & 1.456 & 5.896 \\
\hline Loulsianat & 0.417 & 0.405 & 0.444 & 0.534 & 1.800 \\
\hline 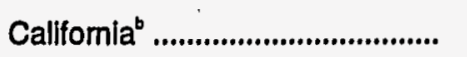 & 0.106 & 0.101 & 0.101 & 0.108 & 0.416 \\
\hline 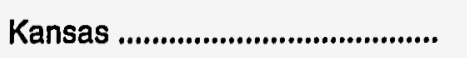 & 0.208 & 0.179 & 0.167 & 0.197 & 0.752 \\
\hline 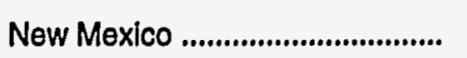 & 0.409 & 0.409 & 0.417 & 0.429 & 1.664 \\
\hline 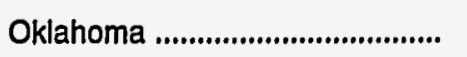 & 0.518 & 0.495 & 0.492 & 0.530 & 2.035 \\
\hline 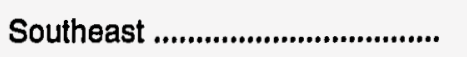 & 0.208 & 0.200 & 0.201 & 0.207 & 0.816 \\
\hline 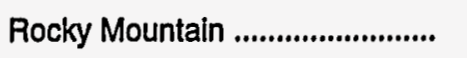 & 0.521 & 0.536 & 0.533 & 0.512 & 2.108 \\
\hline 18 States & 0.242 & 0.219 & 0.228 & 0.219 & 0.908 \\
\hline Lower-48 Total.................. & 5.390 & 5.340 & 5.402 & 5.459 & 21.591 \\
\hline
\end{tabular}

'Texas and Loulsiana exclude Gulf of Mexico OCS.

'California includes Pacific OCS.

Note: Totals may not equal sum of components because of independent rounding.

Source: Energy Information Administration, Office of Oil and Gas. 
productive capacity was less than the demand, then productive capacity was scheduled as production.

For States or areas where monthly gross gas-well gas productive capacity was less than the gross gas-well gas demand, monthly deficits were prorated among the States and areas with surplus gross gas-well gas capacity. This process was repeated until the sum of the monthly scheduled production from all States and areas equaled the monthly lower 48 States gas demand for 1996 and 1997.

The monthly gross gas-well gas productive capacity and oil-well gas production for each State or area were then added to obtain the total monthly gross gas productive capacity and converted to a dry gas basis. The monthly gross gas-well gas scheduled production was added to the oil-well gas production and converted to a dry gas basis.

\section{Drilling and Gas-Well Completions}

The number of new well completions coming on stream is based on a projection of the number of rigs running and an estimate of the number of gas-well completions per rig. The history of the number of rigs running by State and area were obtained from Baker Hughes Incorporated, Marketed Research. Gas-well completions ${ }^{2}$ were obtained from Dwight's production records.

Forecasts of total drilling rigs were obtained from the Drilling Rig Model. This model generates monthly rig counts based on oil and gas revenues which are derived from production and price data appearing in the Short-Term Energy Outlook (STEO).

Data inputs to the Drilling Rig Model are provided by 3 sub-models: the Gas Rig Model, the Percentage Gas Rigs Model, and the Rig Efficiency Model. The number of rigs drilling for gas is of particular importance in this study, and the Percentage Gas Rigs Model, based on STEO oil and gas revenues, provides a forecast of gas rigs. It is also used as input into the Drilling Rig Model.

The Gas Rig Model provides missing historical gas rig counts for input into the Percent Gas Rigs Model. It is based on well completions. The Rig Efficiency Model provides for changes in drilling efficiency and is included as an input to the Drilling Rig Model. It is based on an index of the inverse of wells drilled per working

\footnotetext{
${ }^{1}$ Baker Hughes Incorporated, Marketed Research.

${ }^{2}$ Model GASCAP94 C110196.
}

rig. All of the models are contained in Microsoft Excel spreadsheets. The Excel Solver routine is used to fit and calibrate each model to historical data and minimize the sum of the squared differences in fitting model output to actual historical data.

\section{Gas Rig Model}

Because a longer historical data series was required than is available for the number of rigs drilling for gas, it was necessary to estimate the missing data. The Gas Rig Model, based on gas well completions, was developed to do this. The number of rigs drilling for gas prior to August 1987 was modeled to provide a history for the Percent Gas Rigs Model. The Gas Rig Model is based on the ratio of successful gas wells to total wells from August 1987 through 1994. The number of active rigs comes from Baker Hughes Incorporated Market Research, and well completion data are obtained from the American Petroleum Institute (API). The Gas Rig Model equation is as follows:

$G R_{i}=T R-\left[-8.66688+1.383598+1.104278\left(\frac{\text { SOW }_{i}}{S T W_{i}}\right) \operatorname{SRig} 3 i+8\right]$

where

$$
\begin{array}{ll}
G R & =\text { gas rigs } \\
T R & =\text { total rigs } \\
\text { SOW } & =\text { smoothed oil well completions } \\
S T W & =
\end{array}
$$


The modeled gas rig counts and the post-August 1987 actual gas rig counts are used as input for the Percentage Gas Rigs Model.

\section{Percentage Gas Rigs Model}

The Percentage Gas Rigs Model estimates gas rigs as a percentage of total rigs. Oil and gas incomes (gross revenue) are the input for the model. Production and prices from STEO projections are used to determine income. Lower-48 production and prices are used. Prices are converted to 1992 constant dollars and multiplied by production to yield real income. Oil prices were adjusted for the effects of the Windfall Profits Tax (WPT) from March 1980 through December 1985. Oil and gas incomes are exponentially smoothed in the model. A coalbed gas adjustment factor is applied to the gas income term to account for the non-market incentive or subsidy to gas well drilling from Section 29 tax credits. The adjustment is phased in over 2 years beginning in January 1988, held constant through March 1992, increased again through January 1993, and then eliminated by April 1993. The timing of the coalbed gas adjustment coincides with the evolution and impact of the tax credits. The Percentage Gas Rigs Model equation is as follows:

$$
G R R 3_{i}=100 a\left[1+e S O I_{i}+\left(d\left(\frac{\sum_{i-12}^{1-23} G I_{i}}{12}\right)\left(\frac{S G L_{i}}{S G I_{i-12}}\right)(1+C B)\right],\right.
$$

where

$$
\begin{aligned}
& G R R 3_{i} \text { = percentage gas rigs (gas rig ratio) with } \\
& \text { 3-month exponential smoothing } \\
& \text { (exponential smoothing coefficient }= \\
& \text { 0.5) } \\
& a=0.630263 \text {, model calibration coefficient } \\
& e \quad=-0.00387 \text {, model calibration coefficient } \\
& d \quad=0.002183, \text { model calibration coefficient } \\
& i \quad=\text { current month } \\
& \text { SOI = smoothed oil income } \\
& \text { GI = gas income } \\
& \text { SGI = smoothed gas income } \\
& C B \quad=\text { coalbed gas adjustment factor } \\
& 0.038944=\text { SOI exponential smoothing coefficient }
\end{aligned}
$$

$0.056634=$ SGI exponential smoothing coefficient.

The coalbed gas adjustment factor is as follows:

$$
C B=0.052386(1+0.2[X])[Y](f, g, j) \text {, }
$$

where

$$
\begin{aligned}
& C B=\text { coalbed gas adjustment factor } \\
& 0.052386=\text { model calibration coefficient } \\
& 0.2=\text { model calibration coefficient } \\
& Y \quad=\text { begins January } 1988 \text { at } 1 / 24 \text { th and } \\
& \text { increases by } 1 / 24 \text { th each month until } \\
& \text { equal to } 1 \text {, then held constant at } 1 \\
& X \quad=\text { held constant at }-5 \text { through March } \\
& \text { 1992, then increases by } 1 \text { each month } \\
& \text { until equal to } 5 \text {, then held constant at } 5 \\
& f \quad=5.0, \text { model calibration coefficient used } \\
& \text { only for } 1 \text { month, January } 1993 \\
& g=2.901857 \text {, model calibration coefficient } \\
& \text { used only for } 1 \text { month, February } 1993 \\
& j=0.0 \text {, model calibration coefficient } \\
& \text { beginning in March } 1993 \text { and held } \\
& \text { constant thereafter. }
\end{aligned}
$$

The coalbed gas adjustment factor is in effect from January 1988 through February 1993 only.

\section{Rig Efficiency Model}

The Rig Efficiency Model provides an adjustment of drilling efficiencies as a function of the number of working rigs. It also provides for long term gradual improvements in efficiency due to implementing new and improved technologies. Efficiency is measured as rigs per well. Rigs per well are converted to an index by dividing a running 12-month cumulative rigs per well by an equivalent running 12 -month cumulative rigs per well in 1971. The Rig per Well Index is modeled based on exponentially smoothed rig counts and cumulative rig counts. The modeled Rig per Well Index or the Rig Efficiency Model is used as input for the Drilling Rig Model. The Rig Efficiency Model is as follows:

$$
\begin{aligned}
& R_{W}= \\
& 1+\left[\frac{\text { GRR3 }_{i}}{f}\right] c\left(\exp ^{-b}\left(\frac{\text { CumRig-1 }_{1}}{1,000,000}\right)\right)\left(1+d\left(\frac{\text { SSRig }_{i-1}-\text { SSRig }_{i-13}}{\text { LSRig }_{i-25}}\right)\right),
\end{aligned}
$$


where

$$
\begin{aligned}
& \text { RWI = rig per well index } \\
& \text { CumRig = cumulative rig count beginning } \\
& \text { January } 1968 \\
& \text { SSRig = short-time smoothed rig count } \\
& \text { LSRig = long-time smoothed rig count } \\
& \text { c } \quad=0.471771 \text {, model calibration coefficient } \\
& b=0.362558, \text { model calibration coefficient } \\
& d \quad=1.630099, \text { model calibration coefficient } \\
& \text { f } \quad=31.99129 \text {, model calibration coefficient } \\
& i \quad=\text { current month } \\
& 0.02327=\begin{array}{l}
=\text { SSRig exponential smoothing } \\
\text { coefficient }
\end{array} \\
& 0.03758=\begin{array}{l}
\text { LSRig exponential smoothing } \\
\text { coefficient }
\end{array} \\
& \exp =2.71828, \text { base of the natural logarithm. }
\end{aligned}
$$

\section{Drilling Rig Model}

Like the Percentage Gas Rigs Model, the Drilling Rig Model forecast is based on oil and gas revenue determined from the STEO. Lower-48 prices (in 1992 constant dollars) and production are multiplied to obtain the oil and gas revenues. Oil prices are adjusted for the effects of the WPT. The Percentage Gas Rigs Model is also used as input, along with the Rig Efficiency Model, a seasonality factor, and an adjustment for the Alternative Minimum Tax (AMT). The AMT adjustment is in effect from January 1987 through November 1993, phased in over 1 year (1987) and phased out over 1 year (1993). The seasonality factor is adjusted depending on the trend direction of the rig count. The model uses oil and gas income terms with both variable and constant exponential smoothing coefficients. The variable smoothing coefficients for both oil and gas income contain a rig count smoothed with a variable coefficient. The Drilling Rig Model equation and its component equations are as follows:

$$
\operatorname{Rigs}_{i}=b\left[(1+k) S I_{i}\right]^{d}\left(R W I_{i}\right) A S n_{i}
$$

where

$$
\text { Rigs = number of active drilling rigs }
$$

i cturrent month

$b=1.263626$, model calibration coefficient

$k=-0.03024$, model calibration coefficient for AMT (used from January 1987 through November 1993 only)

$S I \quad=$ smoothed income term (equation A22)

$d \quad=1.311227$, model calibration coefficient

RWI $=$ modeled Rig per Well Index (equation A20)

$A S n=$ adjusted seasonality (equations A26 and A27).

The smoothed income term is as follows:

$$
S I_{i}=S O I V_{i}+\left(\frac{\left(\frac{G R R 3_{i}}{100}\right)}{\left(\frac{S_{\text {GIC }}}{S_{\text {GIC }}+\text { SOIC }_{i}}\right)}\right) S G I V_{i},
$$

where

SI = smoothed income

SOIV = smoothed Oil Income with a variable exponential smoothing coefficient (equation A23)

GRR3 $3_{I}=$ modeled Percentage Gas Rigs (equation A18)

SGIC = smoothed gas income with a constant exponential smoothing coefficient

SOIC = smoothed oil income with a constant exponential smoothing coefficient

SGIV = smoothed gas income with a variable exponential smoothing coefficient (equation A24)

$i \quad=$ current month

$0.320292=$ SOIC and SGIC constant exponential smoothing coefficient.

The variable exponential smoothing coefficient for SOIV is determined by the following equation:

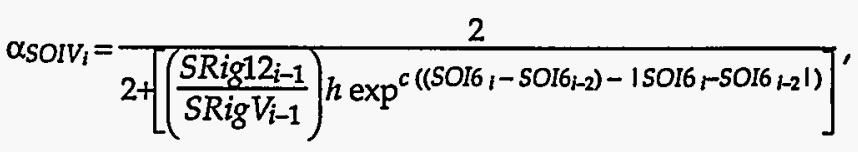




$$
\begin{array}{ll}
\alpha_{S O I V}= & \text { exponential smoothing coefficient for } \\
\text { SOIV } & \\
\text { SRig12 }= & \begin{array}{l}
12 \text {-month exponentially smoothed rig } \\
\text { count (exponential smoothing } \\
\text { coefficient }=0.1538)
\end{array} \\
\text { SRigV }= & \begin{array}{l}
\text { smoothed rig count with a variable } \\
\text { exponential smoothing coefficient } \\
\text { (equation A25) }
\end{array} \\
h & =24, \text { fixed model calibration coefficient } \\
i & =\text { current month } \\
c & =0.5, \text { model calibration coefficient } \\
\text { SOI6 } & =\begin{array}{l}
6-\text { month exponentially smoothed oil } \\
\text { income (exponential smoothing } \\
\text { coefficient }=0.2857)
\end{array}
\end{array}
$$
SRigV = smoothed rig count with a variable exponential smoothing coefficient (equation A25)

The variable exponential smoothing coefficient for $S G N$ is determined by the following equation:

$$
\alpha_{S G I V_{i}}=\frac{2}{2+\left[\left(\frac{S R i g 12_{i-1}}{\text { SRigV } i-1_{1}}\right) \exp ^{f\left(\left(S G I 12_{i}-S G 112_{-2}\right)-\left|S G I 12 i-S G I 12_{i-2}\right|\right)}\right]},
$$

where

$$
\begin{aligned}
& \alpha_{S G I V}{ }_{i}=\underset{S G I V}{\text { exponential smoothing coefficient for }} \\
& \text { SRig12 = 12-month exponentially smoothed rig } \\
& \text { count (exponential smoothing } \\
& \text { coefficient }=0.1538 \text { ) } \\
& S R i g V=\text { smoothed rig count with a variable } \\
& h \quad=24 \text {, fixed model calibration coefficient } \\
& f \quad=0.400367 \text {, model calibration coefficient } \\
& \text { SGI12 = 12-month exponentially smoothed gas } \\
& \text { income (exponential smoothing } \\
& \text { coefficient }=0.1538 \text { ) }
\end{aligned}
$$

The variable exponential smoothing coefficient for SRig $V$ is determined by the following equation:

$$
\alpha_{S R i g V_{i}}=\frac{2}{2+\left[\frac{e}{\left[\exp ^{0.2\left(\left(\text { SRig } 48_{i}-S R i g 48_{i-12}\right)+\mid \text { SRig } 48_{i}-\text { Srig } 48_{i-12} \mid\right)}\right.}\right]} \text {, }
$$

where

$$
\begin{aligned}
\alpha_{\text {SRigV }}= & \text { exponential smoothing coefficient for } \\
& \text { SRig }^{v} \\
\text { SRig48 }= & \begin{array}{l}
48 \text {-month exponentially smoothed rig } \\
\text { count (exponential smoothing } \\
\text { coefficient }=0.0408)
\end{array} \\
\mathrm{e} \quad= & 48, \text { fixed model calibration coefficient } \\
i & =
\end{aligned}
$$

Seasonality factors are calculated for each month and calibrated to a preliminary fit of the Drilling Rig Model that excluded seasonality. That is, seasonality parameters where added to the Drilling Rig Model after fitting and calibrating the model without the seasonality parameters. The model is then run again holding fixed everything other than the seasonality parameters to calibrate only the seasonality coefficients. The seasonality is then held fixed while the nonseasonality parameters were recalibrated in a third fit of the model.

Seasonality is determined by the following equations:

$$
\begin{array}{ll}
S n_{i=1} & =f \text { for January } \\
S n_{i=2} & =f+\frac{l}{2^{i-1}} \text { for February } \\
S n_{i=3} & =f+\frac{l}{2^{i-2}}+\frac{l}{2^{i-1}} \text { for March } \\
S n_{i=4} & =f+\frac{l}{2^{i-3}}+\frac{l}{2^{i-2}}+\frac{l}{2^{i-1}} \text { for April, } \\
S n_{i=5,11} & =S n_{i=4}+j(i-4) \text { for May throughNovember } \\
S n_{i=12} & =S n_{i}=11+\frac{i}{3} \text { for December }
\end{array}
$$

where

$S n=$ the 12 different seasonality factors for January through December 
$i \quad=1$ through 12 for the corresponding months January through December

$f \quad=1.056388$, model calibration coefficient

$l \quad=-0.13269$, model calibration coefficient

$j \quad=0.014967$, model calibration coefficient.

Next, the seasonality is adjusted according to the trend direction as seasonality has less impact when rig counts are increasing than when rig counts are falling. Therefore, adjusted seasonality factors replace the regular seasonality factors as determined by refitting the Drilling Rig Model with only the adjusted seasonality parameters allowed to change. Then, the newly calibrated adjusted seasonality factors are fixed while the Drilling Rig Model is fit one more time to fine tune the nonseasonal coefficients. The adjusted seasonality equation is as follows:

$$
A S n_{i}=1+\frac{\left(S n_{i}-1\right)\left(0.5+0.5 \exp ^{a}\right)}{0.5+0.5 \exp \left(a \frac{S^{a} i g_{i-1}}{\text { SRig }_{i-13}}\right)}
$$

where

$$
\begin{array}{ll}
A S n= & \text { adjusted seasonality factors } \\
i & =\text { current month } \\
S n \quad= & \begin{array}{l}
\text { the } 12 \text { different seasonality factors for } \\
\text { January through December (equation } \\
\text { A26) }
\end{array} \\
a \quad= & 4.037112, \text { model calibration coefficient }
\end{array}
$$

$$
\begin{aligned}
\text { SRig }= & \text { 24-month exponentially smoothed rig } \\
& \text { count (exponential smoothing coefficient } \\
& =0.08)
\end{aligned}
$$

The Drilling Rig Model is then run one last time to determine the value for $k$ in equation (A21) (AMT adjustment). The $1+k$ term is added to the model equation, and all parameters are held constant except $k$. After the value for the coefficient $k$ is determined, the non-AMT and non-seasonal coefficients are determined by refitting the model again. The projected rig counts are spliced to the historical rig counts, by using a 12-month average ratio of actual-to-predicted rigs calculated three months prior to the last month of actual data. Then the forecast is normalized to the last know data with an additive constant.

\section{Exponential Smoothing}

Exponential smoothing is used throughout this modeling process. The following is the basic exponential smoothing equation as applied to income in the Drilling Rig Model.

$$
S I_{i}=I_{i} \alpha+S I_{i-1}(1-\alpha)
$$

where

$$
\begin{array}{ll}
S I & =\text { smoothed income } \\
I \quad & =\text { income } \\
\alpha \quad=\text { exponential smoothing coefficient } \\
i \quad=\text { current month. }
\end{array}
$$


Appendix B

Model Abstract 


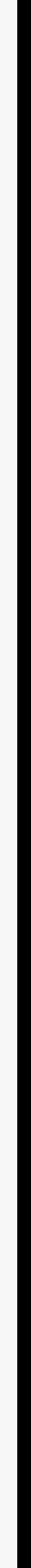




\section{Model Abstract}

Name: Wellhead Gas Productive Capacity

\section{Acronym: GASCAP}

Description: GASCAP estimates the historical wellhead productive capacity of natural gas for the lower 48 States and projects the productive capacity for 3 years. The Short-Term Energy Outlook (STEO) output for low, base, and high cases is used to estimate the number of active rigs and oil and gas well completions. The projected oil production is used to estimate the oil-well gas production (which is assumed to be producing at capacity) by using a constant gas-oil ratio. The gas demand is also taken from STEO. The difference between demand and oil-well gas production is assumed to be the gas-well gas demand and the production as long as capacity exceeds demand.

Purpose: GASCAP is used to project the natural gas wellhead productive capacity for the lower 48 States. It also allows quantification of the available productive capacity and the projected capacity under differing future scenarios.

Date of Last Model Update: September 26, 1996

Part of Another Model: No

References to Any Other Models: None

Documentation reference: Wellhead Gas Productive Capacity Model (GASCAP) Documentation DOE/EIA-M052, March 1995

\section{Official Model Representatives:}

- Office: Oil and Gas

- Division: Reserves and Natural Gas

- Branch: Reserves and Production

- Model Contacts: John H. Wood, James N. Hicks, Hafeez Rahman, Velton T. Funk

- Telephone: 214-767-2200

Archive Media and Installation Guides: Cartridge tape available from NEIC for GASCAP94 for the report Natural Gas Productive Capacity for the Lower 48 States 1985 through 1997, DOE/EIA-0542(96/2).
Energy System Described: GASCAP measures and predicts wellhead natural gas productive capacity.

\section{Coverage:}

- Geographic: Lower-48 natural gas-producing States

- Time Unit/Frequency: Evaluates 13 years of historical data, 1 year of estimated data, and projects productive capacity for 2 years.

- Products: Natural gas

- Economic Sectors: Not applicable

Modeling Features:

- Model Structure: The model consists of a series of Statistical Analysis System (SAS) procedures utilizing a modified rate of gas production versus cumulative gas production (Rate-cum) equation.

- Modeling Techniques: The least squares, nonlinear regression procedure (NLIN) with the Marquardt computational method, was used to fit hyperbolic equations to the data.

- Special Features: Estimates conventional and coalbed gas-well gas productive capacity separately.

Non-DOE Input Variables and Sources:

-Dwight's EnergyData Inc, Richardson, TX, Oil and Gas Reports

- State monthly natural gas production by well

- Baker Hughes Incorporated

- Number of active rotary rigs and number of active rotary gas rigs

- American Petroleum Institute

- Drilling statistics monthly tapes

\section{DOE Data Input Variables and Sources:}

\section{Natural Gas Annual}

- Marketed gas production by State

- Gross gas production by State

- Oil-well gas production by State

\section{Natural Gas Monthly}

- Marketed production of natural gas by State

- Short-Term Energy Outlook

- Dry gas production forecast

- Oil and gas price forecasts 
- Petroleum Supply Annual

- Crude oil production

\section{Computing Environment:}

\section{Main Frame}

- Hardware: IBM 3090E Model 400

-Operating System: MVS/XA

- Languages: FORTRAN / SAS / COBOL

- Memory requirement: $1500 \mathrm{~K}$

- Storage requirement: 1200 tracks of 3380 disk space

- Estimated run time: 4 hours CPU time

\section{Personal Computer}

- Hardware: Compaq Deskpro 386/20

- Operating System: MS DOS for Workgroups 3.11
- Software: LOTUS 123 / EXCEL / ARBITER / HARVARD GRAPHICS

- Memory requirement: $2000 \mathrm{~K}$

- Storage requirement: $10 \mathrm{Mb}$ hard disk space

- Estimated run time: 1 hour

Independent Expert Reviews Conducted:

- Report of findings and recommendations

Paul R. Carpenter, Ph.D.

Brattle/IRI, Inc.

26 June 1995

-Model Quality Audit

Allied Technology Group, Inc.

Prepared by QuanTech, Inc.

29 February 1996

Status of Evaluation Efforts:

-Model Quality Audit report pending. 
Appendix C

Comparison of Productive Capacity 


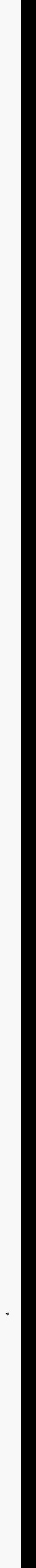




\section{Comparison of Productive Capacity}

Comparisons of base case productive capacities for this and all previous studies were made (Figure $\mathrm{C} 1$ ). In nearly all instances, capacities for the current study were equal to or higher than those in earlier studies.

Figure C1. Comparisons of Base Case Dry Gas Productive Capacity for the 1991, 1993, 1994, 1995, and 1996 Studies

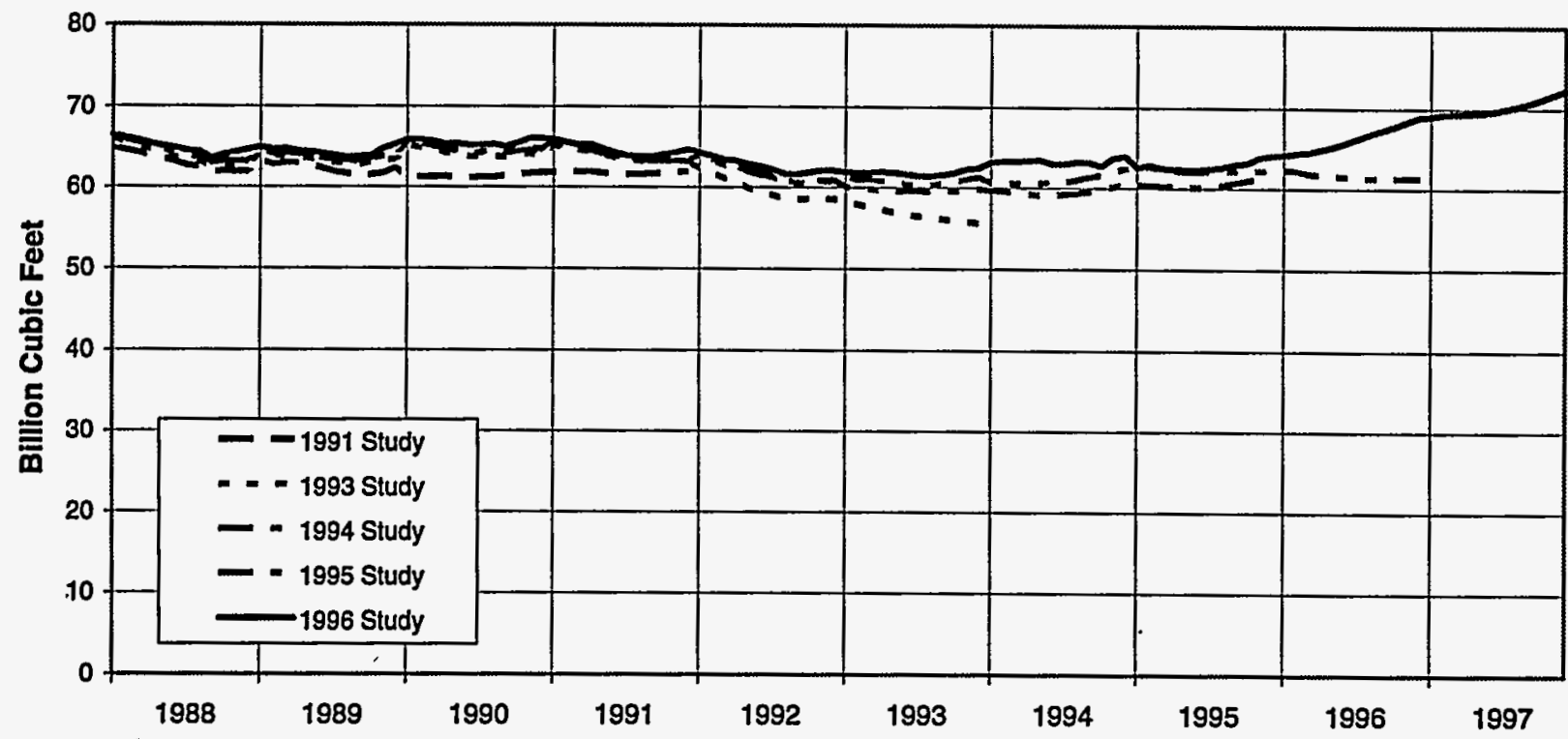

Note: Monthly capacity 6 stimates are for base case.

Sources: 1991 Study: Energy Information Administration. Natural Gas Productive Capacity for the Lower 48 States 1980 Through 1991. DOE/EIA0542(91) (Washington, DC January 24, 1991). 1993 Study: Energy Information Administration. Natural Gas Productive Capacity for the Lower 48 States 1983 Through 1993. DOE/ElA-0542(93) (Washington, DC March 10, 1993). 1994 Study: Energy Information Administration. Natural Gas Productivo Capaclty for the Lower 48 States 1980 Through 1995. DOE/EIA-0542(94) (Washington, DC July 14, 1994). 1995 Study: Energy Information Administrallon. Natural Gas Productive Capacity for the Lower 48 States 1984 Through 1996. DOE/ElA-1542(96) (Washington, DC February 9, 1996). 1996 Study: Model GASCAP94 C092696. 


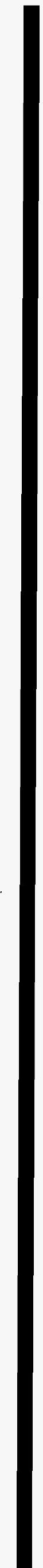


Appendix D

\section{Dry Gas-Well Capacity per New Gas-Well Completion}




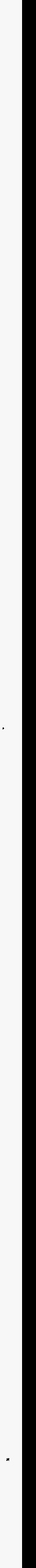




\section{Dry Gas-Well Capacity per New Gas-Well Completion}

Dry gas-well gas productive capacity of about one billion cubic feet per day is added per 1,000 new gas-well gas completions. This is the difference between the dry gas-well productive capacity change for the high case and the base case during 1997 divided by the difference in gas-well completions between the high and base case during 1997. For productive capacity, the period of change is from December 1996 to December 1997 (Table 2). The well completions for the base and high cases are those added during 1997 (Figure 9). Capacity is in billion cubic feet per day (Bcf/day) and the number of completions is in thousands.

The calculation follows:

$$
\begin{aligned}
& =\frac{(69.0 B c f / d a y-61.3 B c f / d a y)-\left(64.6 B c f_{d a y}-61.1 B c f / d a y\right)}{16.4 \text { ThousandCompletions }-13.3 \text { Thousand Completions })} \\
& \approx 1 \frac{B c / d a y}{1000 \text { Gas-well Completions }} \\
& \approx 1 \frac{\text { MMcf/day }}{\text { Gas-well Completion }}
\end{aligned}
$$

The estimate of dry gas-well capacity per new gas-well completion depends on three parameters: initial flow rate $(q i)$; ultimate recovery $\left(G_{u l}\right)$; and the decline exponent $(B)$ (Table D1). These parameters are an average of the parameters obtained from nonlinear regressions of equation (A6) over the data for each area.

(Difference in dry gas-well gas capacity change during 1997 for the high and base case)

(Difference in gas-well completions between the high and base case during 1997)

\begin{tabular}{|c|c|c|c|}
\hline State/Area & $\begin{array}{c}\text { q } \\
\text { Initial Flow Rate } \\
\text { (MMct/day) }\end{array}$ & $\begin{array}{c}G_{u l} \\
\text { Ultimate Recovery } \\
\text { (MMcf) }\end{array}$ & $\begin{array}{c}\text { B } \\
\text { Decline } \\
\text { Exponent }\end{array}$ \\
\hline 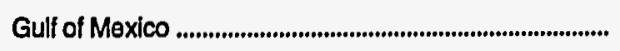 & 7.6 & 4,881 & 1.2 \\
\hline Texas ....................................................................................................... & 1.0 & 982 & 2.2 \\
\hline Loulslana ........................................................................................... & 1.9 & 1,925 & 1.9 \\
\hline 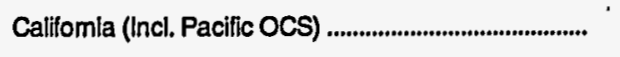 & 1.3 & 990 & 1.7 \\
\hline Kansas ............................................................................................ & 0.4 & 845 & 2.6 \\
\hline 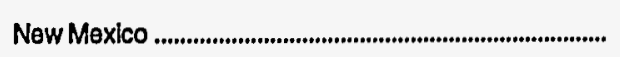 & 0.8 & 1,765 & 2.9 \\
\hline Oklahoma ....................................................................................... & 1.0 & 1,231 & 2.4 \\
\hline Southeast ........................... & 1.5 & 2,918 & 2.0 \\
\hline Rocky Mountain ........................................................................... & 0.6 & 1,032 & 2.7 \\
\hline
\end{tabular}

Table D1. Average Initial Flow Rates, Ultimate Recovery, and Decline Exponent on a Conventional Gas-Well Completion Basis for 1991-1993

Note: Texas and Louisiana exclude Gulf of Mexico OCS; Califomia includes Pacific OCS.

Source: Energy Information Administration, Model GASCAP94 092696. 


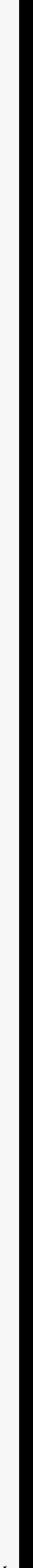




\section{Glossary}





\section{Glossary}

Annual Average-Day Demand: Annual demand divided by the number of days in the year.

Associated Gas: Natural gas, commonly known as gas-cap gas, which overlies and is in contact with crude oil in the reservoir.

Back-pressure: The pressure maintained on equipment or systems through which a fluid flows.

Bcf: Billion cubic feet of gas at a pressure base of 14.73 pounds per square inch absolute and a temperature base of 60 degrees Fahrenheit.

Coalbed Gas: Natural gas that is produced from coalbeds. Methane is the principal component. It is commonly referred to as coalbed methane.

Connected Field Capacity: The Natural Gas Supply Association's definition of Connected Field Capacity is "the rate at which gas can be physically injected into the intrastate and interstate pipeline network, on a 30-day sustainable basis, "under the best of operating conditions (i.e., excluding planned and unplanned downtime). Because the sustainable production rate of a gas field can be lower than that of the individual gas well, the connected capacity is defined on a field basis rather than on a well basis.

Connected field capacity also takes into account the capacity limitations imposed by gathering systems and natural gas processing plants. For example, if a group of wells can physically produce $100 \mathrm{MMcf} /$ day of dry gas, but the gathering system can only transport 90 MMcf/day and the gas processing plant can only produce $70 \mathrm{MMcf} /$ day of dry gas, then the connected field capacity is stated as $70 \mathrm{MMcf} /$ day. The difference between the $100 \mathrm{MMcf} /$ day well production potential and the $70 \mathrm{MMcf} /$ day actually produced by the gas processing plant (i.e., $30 \mathrm{MMcf} /$ day) is considered unconnected field capacity.

Gas productive capacity used to operate gas production and processing facilities was excluded from the survey's consideration.

Deficit Capacity: The negative difference between gas productive capacity and scheduled gas production.
Deliverability: The volume of natuial gas that can be produced from a well, reservoir, or field during a given period of time against a certain wellhead back-pressure under actual reservoir conditions, taking into account restrictions imposed by pipeline capacity, contract, or regulatory bodies.

Demand: U.S. requirement for dry gas from all sources: production, storage withdrawals, supplemental gaseous fuels, and imports.

Dissolved Gas: Natural gas in solution in crude oil in the reservoir.

Dry Gas: Marketed gas less extraction loss.

Extraction Loss: The reduction in volume of natural gas resulting from the removal of natural gas liquid constituents at natural gas processing plants.

Flow String: The string of tubing or casing through which gas or oil flows to the surface.

Gas-Well Gas: Nonassociated or associated gas produced from well completions classified as gas-well completions by a regulatory body.

Gross Gas: Full well stream gas volume, including all natural gas plant liquids and nonhydrocarbon gases, but excluding lease condensate. Also includes amounts delivered as royalty payments or consumed in field operations.

G-10 Rate : Daily gas well production rate calculated as specified on the Railroad Commission of Texas Oil and Gas Division form G-10 and Rule 28.

Lease Condensate: A mixture consisting primarily of pentanes and heavier hydrocarbons which is recovered as a liquid from natural gas in lease or field separation facilities, exclusive of products recovered at natural gas processing plants or facilities.

Marketed Gas: Gross natural gas less gas used for repressuring, quantities vented and flared, and nonhydrocarbon gases removed in treating or processing operations. Includes all quantities of gas used in field and processing operations. 
Mcf: Thousand cubic feet of gas at a pressure base of 14.73 pounds per square inch absolute and a temperature base of 60 degrees Fahrenheit.

MMcf: Million cubic feet of gas at a pressure base of 14.73 pounds per square inch absolute and a temperature base of 60 degrees Fahrenheit.

Nonassociated Gas: Free natural gas not in contact with crude oil in the reservoir.

\section{OCS: Outer Continental Shelf.}

Oil-Well Gas: Natural gas produced from well completions classified as oil-well completions by a regulatory body.

Peak-Day Demand: Highest daily demand that occurred on any one day during the year.

Peak-Month Average-Day Demand: Highest of the 12 monthly demands for the year divided by the number of days in the month.

Peak Shaving: Supplying fuel gas, such as propane, to a distribution system from an auxiliary source during periods of maximum demand, when the primary source is not adequate.

Plant Liquids: Those volumes of natural gas liquids recovered in natural gas processing plants.
Productive Capacity: The volume of natural gas that can be produced from a well, reservoir, or field during a given period of time against a certain wellhead back-pressure under actual reservoir conditions excluding restrictions imposed by pipeline capacity, contract, or regulatory bodies.

Productive Capacity at the Wellhead: The maximum gas production rate that can be sustained for a specific month at the gas-well. It changes over time and cumulatively is a function of gas production and drilling.

Surplus Capacity: The positive difference between gas productive capacity and scheduled gas production.

Tcf: Trillion cubic feet of gas at a pressure base of 14.73 pounds per square inch absolute and a temperature base of 60 degrees Fahrenheit.

Vintage Year: The year in which a well first goes on production.

Water-Drive Reservoir: A reservoir in which the rate of water intrusion into the pay substantially equals the volumetric net rate of oil and gas withdrawal.

Well: A hole made by drilling through strata.

Well Completion: A flow string in a well used to conduct fluids to the surface from one reservoir or zone. A producing well may contain one or more well completions. 


\section{Introducing the Energy InfoDisc ...}

\section{How much oil does the U.S. import from the Persian Gulf?}

How many U.S. households use personal computers?

\section{What's the long range outlook for nuclear power, and how will it affect other fuels?}

\section{How are clean air regulations affecting emissions in the electric power industry?}

Find answers to all your energy questions with Energy InfoDisc, the new CD-ROM providing the most comprehensive collection of energy information and analysis tools available today. Energy InfoDisc is a valuable resource for industry and government analysts, forecasters, journalists, and academic researchers - almost anyone needing access to current or historical energy information.

The Energy InfoDisc comes with advanced search capability to find the information you need in seconds - from over 180 of the most current periodicals and analytical publications of the Energy Information Administration (EIA), the independent statistical and analytical agency within the U.S. Department of Energy. With Energy InfoDisc, you also have instant access to EIA's wide range of national energy databases and special analysis applications. Don't be without this important resource; subscribe today.

\section{STAT-USA Order Form}

Yes, enter my order for the Energy InfoDisc CD-ROM:

Number of copies:

Single issue (U.S., Canada, \& Mexico): \$45

Single issue outside the U.S., Canada \& Mexico: $\$ 60$

Quarterly subscription in the U.S., Canada, \& Mexico: $\$ 100$ Quarterly subscription outside the U.S., Canada \& Mexico: $\$ 160$

Contact or personal name

(please type or print)

Company

Street address

Additional address

Clty, State, ZIP Code

Daytime phone

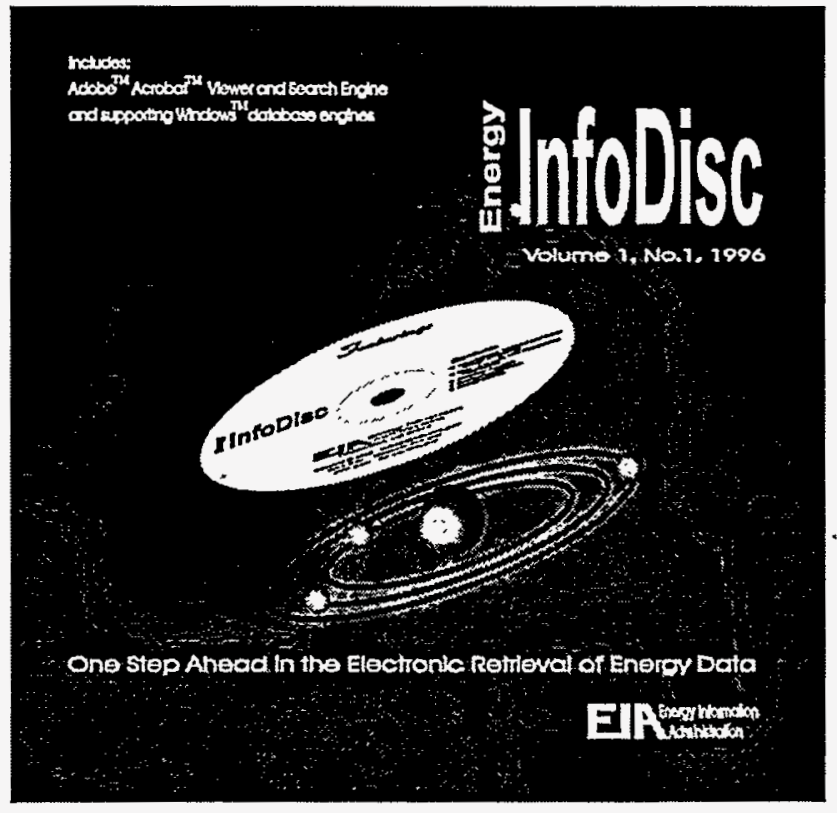

NOTE: Documents can be accessed using either Microsoft Windows or Macintosh System 7 operating systems. Databases and applications can only be accessed using Microsoft Windows.
Charge your order

It's easy!

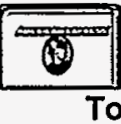

\section{MITCVE}

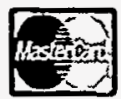

VISF

To fax your orders (202) 482-2164

To phone your orders (202)482-1986

For privacy protection, check the box below:

$\square$ Do not make my name available to requesters.

Check method of payment:

AMEX $\square$ Discover $\square$ MasterCard $\square$ VISA

(expiration date)

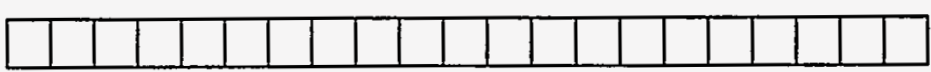

Thank you for your order!

Authorizing signature

$3 / 96$

Check payable to STAT-USA

Mail to: U.S. Department of Commerce

STAT-USA, Room H-4885

Washington, DC 20230 